UNIVERSIDADE FEDERAL DO AMAZONAS PRÓ-REITORIA DE PESQUISA E PÓS-GRADUAÇÃO

FACULDADE DE TECNOLOGIA

PROGRAMA DE PÓS-GRADUAÇÃO EM ENGENHARIA DE PRODUÇÃO

GESTÃO DA CADEIA DE SUPRIMENTOS DA SECRETARIA MUNICIPAL DE SAÚDE DE MANAUS: UMA PROPOSTA DE OTIMIZAÇÃO DO PROCESSO DE AQUISIÇÃO DE MEDICAMENTOSS.

CRISTIANO BARBOSA DE LIMA 


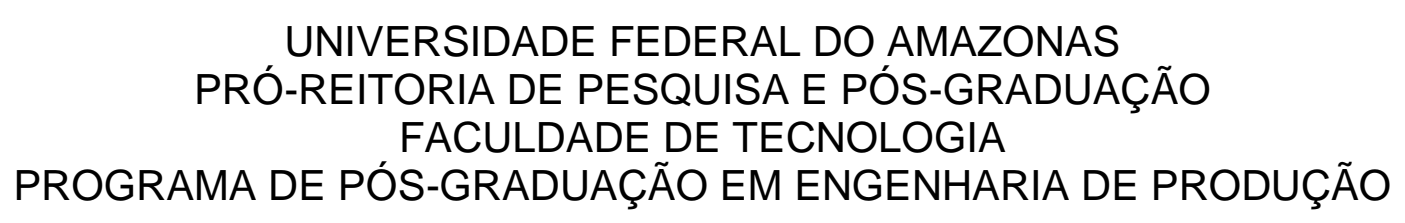

CRISTIANO BARBOSA DE LIMA

GESTÃO DA CADEIA DE SUPRIMENTOS DA SECRETARIA MUNICIPAL DE SAÚDE DE MANAUS: UMA PROPOSTA DE OTIMIZAÇÃO DO PROCESSO DE AQUISIÇÃO DE MEDICAMENTOS.

Dissertação apresentada ao Programa de Pós-Graduação em Engenharia de Produção da Universidade Federal do Amazonas, como parte do requisito para obtenção do título de Mestre em Engenharia de Produção, área de concentração Gestão de Operações e Serviços.

ORIENTADOR: PROF. DR. ARMANDO ARAÚJO DE SOUZA JÚNIOR 
Ficha Catalográfica

Ficha catalográfica elaborada automaticamente de acordo com os dados fornecidos pelo(a) autor(a).

L732g Gestão da Cadeia de Suprimentos da Secretaria Municipal de Saúde de Manaus: uma proposta de otimização do processo de aquisição de medicamentos / Cristiano Barbosa de Lima. 2017 149 f.: il.; $31 \mathrm{~cm}$.

Orientador: Dr. Armando Araújo de Souza Júnior Dissertação (Mestrado em Engenharia de Produção) Universidade Federal do Amazonas.

1. Gestão da Cadeia de Suprimentos. 2. Lean Office. 3. Teoria das Restrições. 4. Compras Públicas. 5. Medicamentos. I. Souza Júnior, Dr. Armando Araújo de II. Universidade Federal do Amazonas III. Título 
CRISTIANO BARBOSA DE LIMA

\title{
GESTÃO DA CADEIA DE SUPRIMENTOS DA SECRETARIA MUNICIPAL DE SAÚDE DE MANAUS: UMA PROPOSTA DE OTIMIZAÇÃO DO PROCESSO DE AQUISIÇÃO DE MEDICAMENTOS.
}

\begin{abstract}
Dissertação apresentada ao Programa de Pós-Graduação em Engenharia de Produção da Universidade Federal do Amazonas, como parte do requisito para obtenção do título de Mestre em Engenharia de Produção, área de concentração Gestão de Operações e Serviços.
\end{abstract}

Aprovado em 31 de março de 2017

BANCA EXAMINADORA

Prof. Dr. Armando Araújo de Souza Júnior, Presidente Universidade Federal do Amazonas - UFAM

Prof. Dr. Claudio Dantas Frota, Membro Universidade Federal do Amazonas - UFAM

Profa. Dra. Luiza Maria Bessa Rebelo, Membro Universidade Federal do Amazonas - UFAM 


\section{DEDICATÓRIA}

Ao marceneiro que passou a vida toda me dizendo: "meu filho, estude, a única coisa que vai fazer você crescer na vida são os estudos", Pedro Lima Rodrigues (18.02.1939-14.07.2014).

A ex-empregada doméstica que mesmo com limitações e escassez de recursos, sempre que ia ao Centro passava na Lobras e comprava um Playmobil pra mim, Raimunda Barbosa da Penha, minha mãe.

Dr. Aldemar e D. Maria Olinda que sempre me trataram como um de seus filhos e nunca como filho da empregada. Obrigado por terem ajudado na minha formação.

"Senhor Jesus ajude meu pai a concluir seu mestrado". Era a oração da minha filha Letícia.

"Mulher virtuosa, quem a achará?" Eu! Rachel Lima. 


\section{AGRADECIMENTOS}

Ao Prof. Dr. Armando Araújo de Souza Júnior. Professor na Graduação de Administração e Orientador no Mestrado. Sem o senhor não teria conseguido. Obrigado Mestre.

A Prefeitura Municipal de Manaus que através da Escola de Serviço Público Municipal (ESPI) proporcionou a realização deste Mestrado em Engenharia de Produção em convênio com a Universidade Federal do Amazonas (UFAM).

Ao Prof. Dr. Claúdio Dantas Frota. Professor na Graduação de Administração e no Mestrado. Foi o grande incentivador para eu participar do processo seletivo do Mestrado em Engenharia de Produção - ESPI/UFAM.

A Profa. Dra. Luiza Bessa. Professora na Graduação de Administração, gestora da ESPI e atual Secretária Municipal de Administração. É uma honra tê-la na banca.

Ao Prof. Dr. Waltair Vieira Machado, maestro desta parceria da UFAM com a ESPI.

Ao Departamento de Logística (DELOG) na pessoa da Diretora Vanda Viana, que abriu as portas do DELOG sem restrições para realização desta pesquisa.

Aos colegas do DELOG que facilitaram e muito meu trabalho de pesquisa: Nidson Fonseca (Gerente de Planejamento e Logística), Ricardo Militão (Chefe da Divisão de Almoxarifado), Daiana Vieira, Carlos Bahia, Brasil, e Judite.

Aos ex-colegas do Departamento de Logística Jean Abreu e Daniela Martine, trabalhar com vocês foi a melhor parte em dez anos de serviço público.

Aos colegas da SEMSA: Rogério Carminé (Diretor Departamento de Tecnologia da Informação), Alexandra Muniz (Chefa da Divisão de Manutenção de Sistemas), Maria José Padilha (Chefa da Divisão de Registro de Preços), Geraldo Souza (Chefe do Setor de Informações, Controle, Avaliação e Regulação), Sammyra Gomes (Chefa do Núcleo de Monitoramento e Avaliação/DISA Sul).

A Igreja Vida, pelo carinho, apoio e compreensão durante este período de Mestrado, muito obrigado.

A minha esposa Rachel e minha filha Letícia. Este Mestrado é para vocês.

"Sr. Jesus, eu não havia percebido que este Mestrado era apenas uma oportunidade disfarçada. Obrigado! Tudo sempre esteve no Seu controle". 
"Stay Hungry. Stay Foolish." Steve Jobs 


\section{RESUMO}

Preconizada pela Constituição de 1988 e estabelecida pelo Sistema Único de Saúde (SUS), a saúde é um direito de todos os brasileiros, sendo dever do Estado e seus entes confederados assegurar o acesso universal e igualitários dos serviços de saúde, inclusive o acesso aos medicamentos. Entretanto, tal garantia gera um enorme esforço logístico, técnico, operacional e financeiros por partes do Poder Público Municipal. Diante deste problema, surge a questão norteadora: Quais as principais restrições que afetam o processo de aquisição de medicamentos na Rede Municipal de Saúde de Manaus? Tal pesquisa justifica-se pela necessidade de melhorar a gestão da cadeia de suprimentos de medicamentos, promoção da economicidade dos recursos públicos e aplicação dos conceitos da Engenharia de Produção no Setor Público. O objetivo geral: Propor um Modelo de otimização do Processo de Aquisição de medicamentos na Rede Municipal de Saúde de Manaus. Objetivos específicos: (1) Mapear o Fluxo Operacional da Gestão da Cadeia de Suprimentos de medicamentos, (2) Mapear o Fluxo de Valor Presente do Processo de aquisição de medicamentos, (3) Identificar as restrições e propor um Mapa de Valor Futuro para aquisição de medicamentos, (4) Apresentar sugestões de melhorias no Processo de distribuição de medicamentos e (5) Apresentar Painel de Indicadores para Gerenciar o Processo de aquisição de medicamentos. Para tanto, utilizou como metodologia o Estudo de Caso. Os dados da pesquisa indicam que os Fornecedores de Medicamentos são a principal restrição no sistema, formulando-se assim a Proposta do Modelo de otimização do Processo de Aquisição de medicamentos a fim de equacionar esta restrição: (1) Planejar as Aquisições de Medicamentos, (2) Diminuir a quantidade de ordens de aquisição usando Lotes Econômicos, (3) Programar a entrega dos Lotes, (4) Envolver os Stakeholders no Planejamento, (5) Padronizar o Fluxo de Tramitação dos Processos e (6) Aprimorar a Gestão de Materiais.

PALAVRAS CHAVES: Gestão da Cadeia de Suprimentos - Lean Office - Teoria das Restrições - Compras Públicas - Medicamentos 


\begin{abstract}
Under the 1988 Constitution and established by the Unified Health System (SUS), health is a right of all Brazilians, and it is the duty of the state and its confederate entities to ensure universal and equal access to health services, including access to medicines. However, this guarantee generates a huge logistical, technical, operational and financial effort by the Municipal Public Authorities. Faced with this problem, the guiding question arises: What are the main restrictions that affect the process of acquisition of medicines in the Municipal Health Network of Manaus? Such research is justified by the need to improve the management of the supply chain of medicines, promotion of the economicity of public resources and application of the concepts of Production Engineering in the Public Sector. The general objective: To propose an Optimization Model of the Drug Procurement Process in the Municipal Health Network of Manaus. Specific Objectives: (1) Map the Operational Flow of Supply Chain Management of drugs, (2) Map the Present Value Flow of the drug procurement process, (3) Identify the constraints and propose a Future Value Map for acquisition (4) Present suggestions for improvements in the Medication Distribution Process and (5) Present Indicators Panel to Manage the Drug Procurement Process. For that, he used the Case Study as methodology. The research data indicate that Drug Suppliers are the main constraint in the system, thus formulating the Proposal of the Optimization Model of the Drug Procurement Process in order to equate this restriction: (1) Plan Medication Acquisitions, (2) Decrease the number of purchase orders using Economic Lots, (3) Schedule Batch Delivery, (4) Involve Stakeholders in Planning, (5) Standardize Process Flow, and (6) Improve Material Management.
\end{abstract}

KEYWORDS: Supply Chain Management - Lean Office - Theory of Constraints Government Procurement - Medicines 


\section{LISTA DE FIGURAS}

Figura 1 - Modelo de Gestão Cadeia de Suprimentos

Figura 2 - Fluxo do Processo

Figura 3 - Processos de Negócios Através da Cadeia de Suprimentos

Figura 4 - Estrutura da Gestão da Cadeia de Suprimentos

Figura 5 - Exemplo de um VSM

Figura 6 - Etapas da Teoria das Restrições

Figura 7 - Metodologia

Figura 8 - Estrutura Administrativa do DELOG

Figura 9 - Fases do Planejamento do Projeto de Pesquisa

Figura 10 - Detalhes das Etapas da Pesquisa

Figura 11 - Estrutura Administrativa do DELOG

Figura 12 - Banco de Dados Primário

Figura 13 - Banco de Dados Processos - I

Figura 14 - Banco de Dados Processos - II

Figura 15 - Banco de Dados Empenhos

Figura 16 - Banco de Dados Fontes

Figura 17 - Arquivo de Receituário Médico de uma UBSF

Figura 18 - Calendário de Abastecimento DELOG (Segundo semestre 2016)

Figura 19 - Cronograma de Abastecimento de Medicamentos

Figura 20 - Value Stream Mapping Presente - Abastecimento de Medicamentos.

Figura 21 - Mapeamento do Fluxo de Valor Presente Processo de Aquisição de Medicamento

Figura 22 - VSM Futuro Processo de Aquisição de Medicamento

Figura 23 - Modelo de Otimização do Processo de Aquisição de Medicamentos 


\section{LISTA DE QUADROS}

Quadro 1 - Definições: Gestão da Cadeia de Suprimentos

Quadro 2 - Componentes de Gestão

Quadro 3 - Princípios da Administração Pública

Quadro 4 - Modalidades de Licitação

Quadro 5 - Tipos de Licitação

Quadro 6 - Peculiaridades do Registro de Preços

Quadro 7 - Legislação Modalidade Pregão

Quadro 8 - Fases do Pregão Presencial e Eletrônico

Quadro 9 - Vantagens do Sistema de Compras Eletrônico

Quadro 10 - Princípios do Pensamento Enxuto

Quadro 11 - Princípios para Implantar o Lean Office

Quadro 12 - Categorias de Desperdício Manufatura x Escritório

Quadro 13 - Quadro comparativo Rother e Shook (2003) x Tyagi et. al. (2015)

Quadro 14 - Aplicabilidade do Value Stream Mapping

Quadro 15 - Eixos Macros

Quadro 16 - Cadeia de Suprimento de Medicamentos

Quadro 17 - Estrutura Administrativa da SEMSA

Quadro 18 - Rede Física de Saúde

Quadro 19 - Distrito de Saúde x Exemplo de EAS

Quadro 20 - Campos Banco de Dados Primário

Quadro 21 - Campos Banco de Dados Processos

Quadro 22 - Registros Indevidos

Quadro 23 - Campos Banco de Dados Empenhos

Quadro 24 - Campos Banco de Dados Tramitação Processos

Quadro 25 - Quantidade de Processos Administrativos

Quadro 26 - Estimativa de Custos com Processos Administrativos

Quadro 27 - Quantidade de Empenhos

Quadro 28 - Empenhos Válidos

Quadro 29 - Dotação Orçamentária x Valor Empenho

Quadro 30 - Tempo Médio Autorização para Processar

Quadro 31 - Tempo Médio PROTUS até Nota de Empenho 
Quadro 32 - Exemplos de Diferentes Fluxos de Tramitação de Processos de Aquisição de Medicamentos - 2015

Quadro 33 - Tempo Médio PROTUS até Nota de Empenho

Quadro 34 - Tempo Médio Fornecedor Entregar Medicamentos

Quadro 35 - Dotação Orçamentária x Empenhos x Valor Entregue

Quadro 36 - Fluxo Operacional da Cadeia de Suprimentos de Medicamentos

Quadro 37 - Identificação do Processo Administrativo

Quadro 38 - Identificação do Empenho

Quadro 39 - Fluxo Operacional Abastecimento de Medicamentos EAS

Quadro 40 - Proposta de Fluxo Operacional Abastecimento de Medicamentos EAS

Quadro 41 - Mensuração de Tempos nos Pedidos de Abastecimento

Quadro 42 - Processos Administrativos para Aquisição de Medicamentos

Quadro 43 - Exemplos de Diferentes Fluxos de Tramitação de Processos de Aquisição de Medicamentos - 2015

Quadro 44 - Painel de Indicadores Financeiros

Quadro 45 - Painel de Indicadores de Produtividade 


\section{LISTA DE GRÁFICOS}

Gráfico 1 - Dotação Orçamentária Assistência Farmacêutica

Gráfico 2 - Evolução do Valor das Compras Públicas (segundo tipo de processo)

Gráfico 3 - Evolução da Economia do Pregão Eletrônico nas Licitações Públicas

Gráfico 4 - Estudos Visando Otimizar o Processo de Compras dos Estados

Gráfico 5 - Quantidade de Processos Licitatórios e Valores

Gráfico 6 - Número Médio de Licitantes

Gráfico 7 - Tempo Médio de Duração Processo de Aquisição 


\section{LISTA DE SIGLAS}

CEO

DAB

DELOG

DIMED

DISA

DISA Leste

DISA Norte

DISA Oeste

DISA Rural

DISA Sul

DIVAL

DIVPA

EAS

FMI

GCS

MMT

PIB

PROTUS

SAMU

SCM

SEMSA

SETIN

STP

SUBGAP

SUS

TCC

$\mathrm{TI}$

TOC

UBS

UBSF

VSM
Centro de Especialidade Odontológica

Departamento de Atenção Básica

Departamento de Logística

Divisão de Medicamentos

Distrito de Saúde

Distrito de Saúde Leste

Distrito de Saúde Norte

Distrito de Saúde Oeste

Distrito de Saúde Rural

Distrito de Saúde Sul

Divisão de Almoxarifado

Divisão de Patrimônio

Estabelecimento Assistencial de Saúde

Fundo Monetário Internacional

Gestão da Cadeia de Suprimentos

Maternidade Moura Tapajós

Produto Interno Bruto

Sistema de Protocolo Integrado

Serviço de Atendimento Móvel de Urgência

Supply Chain Management

Secretaria Municipal de Saúde

Setor de Insumos

Sistema Toyota de Produção

Subsecretaria de Gestão Administrativa e Planejamento

Sistema Único de Saúde

Trabalho Conclusão de Curso

Tecnologia da Informação

Theory of Constraints

Unidade Básica de Saúde

Unidade Básica de Saúde da Família

Value Stream Mapping 


\section{SUMÁRIO}

1. INTRODUÇÃO

1.1 SITUAÇ̃̃O PROBLEMA

$\begin{array}{lr}1.2 \text { OBJETIVOS } & 19\end{array}$

$\begin{array}{ll}1.3 \\ 1.4 U S T I F I C A T I V A & 20\end{array}$

1.4 ESTRUTURA DO TRABALHO 23

2. REVISÃO DA LITERATURA 24

2.1 GESTÃO DA CADEIA DE SUPRIMENTOS (GCS)

2.2 COMPRAS PÚBLICAS 36

2.3 LEAN OFFICE $\quad 50$

2.4 TEORIA DAS RESTRIÇÕES (TOC) 61

3. PROCEDIMENTOS METODOLÓGICOS 63

3.1 MÉTODO DA PESQUISA: ESTUDO DE CASO 66

3.2 LÓCUS DA PESQUISA: DEPARTAMENTO DE LOGÍSTICA - DELOG 67

3.3 PROCESSO DE PESQUISA 69

3.4 INSTRUMENTO DE COLETA DE DADOS

3.5 ANÁLISE DOS RESULTADOS

4. GESTÃO DA CADEIA DE SUPRIMENTOS DE MEDICAMENTOS

4.1 EMPRESA FOCAL: SECRETARIA MUNICIPAL DE SAÚDE DE MANAUS 75

4.2 DADOS DA GESTÃO DA CADEIA DE SUPRIMENTOS DE 84

MEDICAMENTOS

4.3 FLUXO OPERACIONAL DA GESTÃO DA CADEIA DE SUPRIMENTOS 100 DE MEDICAMENTOS.

4.4 SUGESTÕES DE MELHORIAS NA GESTÃO DA CADEIA DE 105 SUPRIMENTOS: A JUSANTE

4.5 VSM PRESENTE DA GESTÃO DA CADEIA DE SUPRIMENTOS DE 119

MEDICAMENTOS: A MONTANTE

4.6 PROPOSTA DE MODELO DE OTIMIZAÇÃO DO PROCESSO DE 127

AQUISIÇÃO DE MEDICAMENTO

4.7 PAINEL DE INDICADORES PARA A GESTÃO DA CADEIA DE 134

SUPRIMENTOS

5 CONSIDERAÇÕES FINAIS E RECOMENDAÇÕES 137

5.1 RECOMENDAÇÕES 138

6. REFERÊNCIAS BIBLIOGRÁFICAS 139

ANEXO 1 - CALENDÁRIO DE ABASTECIMENTO DE MEDICAMENTOS - 147

PRIMEIRO SEMESTRE 2015

ANEXO 2 - CALENDÁRIO DE ABASTECIMENTO DE MEDICAMENTOS - 148

SEGUNDO SEMESTRE 2016

ANEXO 3 - MAPA DE ABASTECIMENTO DE MEDICAMENTOS 


\section{INTRODUÇÃO}

A Constituição Federal de 1988 preconiza que a saúde é um direito de todos os brasileiros, assegurando a redução do risco de doenças e de outros agravos à saúde, bem como o acesso universal e igualitário às ações e serviços para sua promoção, proteção e recuperação, através de políticas sociais, públicas e econômicas, sendo um dever do Estado e seus entes confederados (BRASIL, 1988).

Para tanto, a legislação estabelece que o Sistema Único de Saúde (SUS), criado através da Lei ํo 8.080 de 19 de setembro de 1990, deve garantir tudo o que for necessário para prevenir, tratar e curar as doenças, inclusive o acesso aos medicamentos, que são distribuídos gratuitamente aos usuários do SUS mediante receita médica, normalmente em um Estabelecimento Assistencial de Saúde - EAS (BRASIL, 1990).

O acesso aos medicamentos por parte dos usuários do SUS exige uma grande estrutura logística para aquisição (logística de suprimentos), armazenagem (logística interna), distribuição aos Estabelecimentos Assistenciais de Saúde (logística de distribuição) e em muitos casos, quando os medicamentos perdem a validade, a gestão pública precisa fazer a retirada e correto descarte destes medicamentos (logística reversa).

A gestão desta estrutura logística (aquisição - armazenagem - distribuição reversa), é descrita na literatura como Gestão da Cadeia de Suprimentos (MENTZER, 2001).

A Gestão da Cadeia de Suprimentos tem tomado nítida expressão nos trabalhos acadêmicos e em publicações científicas, isto posto, devido ao processo evolutivo do conceito de cadeia, ampliando o conceito de logística, onde todos os stakeholders, a montante e a jusante têm seus processos de trabalho ajustados a fim de conseguirem melhores resultados para a Empresa Focal bem como para o cliente final (MENTZER, 2001; BALLOU, 2006; MACHLINE, 2011; SIMON et al., 2015).

As Empresas privadas têm a Gestão da Cadeia de Suprimentos como fator estratégico e competitivo, pois através de uma gestão bem sucedida, é possível diminuir o custo logístico total e aumentar a lucratividade (BALLOU, 2006). Aplicando o mesmo princípio ao Setor Público vislumbra-se uma possibilidade de usar os recursos do erário do Município com maior eficiência e economicidade. 
Por se tratar de um Mestrado Profissionalizante com fins acadêmicos, mas com um viés voltado para o campo do trabalho/serviço, foi pesquisado a Gestão da Cadeia de Suprimentos de medicamentos da Secretaria Municipal de Saúde de Manaus (SEMSA) no recorte temporal dos anos de 2013 a 2015. Este recorte temporal de três anos justifica-se pelo fato de fazer parte do exercício vigente da atual administração pública (2013 a 2016).

A Secretaria Municipal de Saúde de Manaus (SEMSA), empreende um grande esforço financeiro e de capital humano para cumprir o que preconiza a legislação a fim de disponibilizar os medicamentos necessários para o tratamento de saúde dos usuários do SUS que diariamente são atendidas nos Estabelecimentos Assistenciais de Saúde (EAS) de Manaus.

Por uma questão estratégico-operacional, a estrutura da SEMSA possui cinco unidades administrativas, denominadas Distritos de Saúde (DISA), distribuídos taticamente em cada zona geográfica da Cidade, que coordenam um grupo de EAS que estão sob sua "jurisdição", ou seja, na sua área geográfica. Atualmente os Distritos de Saúde são: DISA Norte, DISA Sul, DISA Leste, DISA Oeste e DISA Fluvial.

Os Estabelecimentos Assistenciais de Saúde compõem uma rede com mais de duzentas e cinquenta unidades de saúde com tipologia variada, dependendo do seu escopo, atuação e capacidade instalada.

Em cada EAS há distribuição de medicamentos aos usuários do SUS (conforme receita médica) ou se não distribuem, ao menos há a necessidade de terem os medicamentos e demais insumos para a saúde, como é o caso do Serviço de Atendimento Móvel de Urgência (SAMU), Centro de Especialidade Odontológica (CEO) e Maternidade Moura Tapajós (MMT).

O Departamento de Logística (DELOG) exerce papel fundamental na Gestão da Cadeia de Suprimentos, pois é o órgão competente, dentro da estrutura administrativa da Secretaria Municipal de Saúde, para gerir toda a cadeia de suprimentos de medicamentos, sendo responsável pelos processos administrativos para licitação de medicamentos; processos administrativos para aquisição de medicamentos através de Ata de Registro de Preços; receber e armazenar os medicamentos; distribuir os medicamentos para a Rede de Estabelecimentos Assistenciais e recolher os medicamentos em caso de perda da validade. 
No bojo desta discussão, verificou-se a importância de analisar a Gestão da Cadeia de Suprimentos da SEMSA, especificamente o Processo de aquisição (input) de medicamentos.

\subsection{SITUAÇÃO PROBLEMA}

A aquisição (input) de qualquer bem, produto ou serviço no âmbito da esfera pública é regulamentado pela Lei n 8.666, de 21 de junho de 1993 (BRASIL, 1993), que é um instrumento administrativo com objetivo de disciplinar e normatizar o processo de compras/aquisição/contratação através de licitação pública. A licitação tem por objetivo afiançar o cumprimento do princípio constitucional da isonomia e a selecionar a proposta mais vantajosa para a Administração Pública, a fim de evitar fraudes e desvio de dinheiro público (BRASIL, 2006).

Não obstante ser uma conquista e grande avanço, a licitação torna leniente e moroso o processo de aquisição e contratação de serviços. Tridapalli e Ferrer (2006) afirmam que nesta área de compras públicas foi criado a maior estrutura burocrática para controle e prevenção de possíveis desvios. Todo processo administrativo para aquisição precisa estar rigorosamente dentro do que estabelece a legislação, caso contrário, a Administração Pública estará passiva de sofrer as penalidades impostas em Lei (BRASIL, 1993).

No que tange a aquisição especificamente de medicamentos, além da Lei no 8.666 de 21 de junho de 1993 que norteia o processo de licitação, a Administração Pública também precisa observar o que preconiza a Política Nacional de Medicamentos e a Política Nacional de Assistência Farmacêutica (BRASIL, 2006).

$\mathrm{Na}$ Secretaria Municipal de Saúde de Manaus, como mencionado anteriormente, o setor responsável pela abertura de processo administrativo para licitação de medicamentos e insumos para saúde, bem como os processos administrativos para aquisição de medicamentos e insumos para saúde através de Ata de Registro de Preços é o Departamento de Logística.

Dentro da estrutura administrativa da SEMSA também existe a Assistência Farmacêutica, vinculada ao Departamento de Atenção Primária (DAP), que segundo a Política Nacional de Medicamentos e a Política Nacional de Assistência Farmacêutica, deveria ser o ator principal no processo de aquisição de medicamentos e insumos para a saúde (BRASIL, 2006). 
Segundo a legislação, é função da Assistência Farmacêutica: (1) gerenciar o processo de aquisição de medicamentos; (2) gestão de estoque; (3) distribuir e dispensar medicamentos; (4) promover uso racional de medicamentos; etc. (BRASIL, 2006).

Não existe no âmbito da SEMSA uma política de aquisição de medicamentos, com diretrizes claras, prioridades, normas e procedimentos para dar agilidade ao processo e evitar o desabastecimento, conforme preceitua a legislação (BRASIL, 2006).

Em geral, os processos administrativos para licitação de medicamentos e processos administrativos para aquisição através de Ata de Registro de Preços tramitam normalmente na Secretaria, como outro processo administrativo qualquer, sem nenhum tipo de prioridade ou urgência, desprezando sua natureza e peculiaridade na esfera da saúde pública.

Existe ainda um lead time que precisou ser mensurado. $O$ tempo que o Fornecedor demora em tomar ciência da emissão do Empenho pela Secretaria. Este tempo não é estipulado pela legislação (BRASIL, 1993), ficando a critério do Edital de Licitação. Via de regra, o Fornecedor tem cinco dias úteis para tal procedimento. Mas este tempo pode se estender e não existe um instrumento administrativo que o obrigue a tomar ciência com maior brevidade. A partir da data que toma ciência, o mesmo tem trinta dias para efetuar a entrega dos itens descritos no Empenho.

A entrega dos medicamentos e insumos de saúde por parte dos Fornecedores é outra preocupação da Administração Pública. Como não existe Indústria Farmacêutica em Manaus e os Fornecedores não têm estoque, a grande maioria dos medicamentos e insumos para saúde vêm de fora da Cidade, havendo ainda um tempo considerado até a entrega dos mesmos no DELOG.

Outro problema relacionado à aquisição de medicamentos é programar os quantitativos a serem adquiridos. A Política Nacional de Medicamentos e a Política Nacional de Assistência Farmacêutica indicam a utilização combinada de quatro métodos: (1) perfil epidemiológico; (2) consumo histórico; (3) ofertas de serviços; (4) consumo médio mensal (BRASIL, 2006). Todavia, o DELOG utiliza apenas o consumo histórico e o consumo médio mensal para programar os quantitativos de medicamentos e insumos para a saúde que serão licitados ou adquiridos através de Ata de Registro de Preços. 
Outro problema da Gestão da Cadeia de Suprimentos de medicamentos da SEMSA está na distribuição (output) ao usuário final, devido ao fato que a Gestão da Demanda da Cadeia de Suprimentos ocorre prioritariamente dentro dos Estabelecimentos Assistenciais de Saúde. Falhas neste processo causará um efeito chicote, a montante na cadeia de suprimentos (com influência negativa no nível de estoque de segurança), na gestão de estoques e principalmente no planejamento de aquisições de medicamento (SANTOS; ALVES, 2015).

No contexto atual, não existe Sistema de Informação nos Estabelecimentos Assistenciais de Saúde para controle do estoque dos medicamentos (entradas, saídas, lotes, validade, etc.). Todo trabalho é feito de forma manual.

O Ministério da Saúde disponibiliza um Sistema de Informação chamado HÓRUS para gestão dos medicamentos e insumos dos componentes da Assistência Farmacêutica. Segundo Portal do Ministério da Saúde ${ }^{1}$, a SEMSA fez adesão ao Sistema, mas ainda não implantou nos EAS.

Nessa direção, esses atenuantes de input e output possuem impacto negativo na Gestão da Cadeia de Suprimentos, acarretando em muitos momentos o desabastecimento de medicamentos na Rede de Saúde, ou seja, faltando o medicamento ao usuário final, que não poderá dar continuidade ao seu tratamento de saúde; ou no excesso, acarretando perdas de medicamentos, obrigando a Administração Pública a contratar Empresa para fazer o correto descarte dos mesmos, aumentando os custos.

Do ponto de vista social, é perceptível a comoção da população diante do quadro de medicamentos vencidos sendo descartados e a exploração da imprensa gerando um desgaste político da Administração.

Diante deste cenário, a questão norteadora deste projeto de pesquisa ficou definida como: Quais as principais restrições que afetam o processo de aquisição de medicamentos na rede municipal de saúde de Manaus?

\subsection{OBJETIVOS}

O presente projeto de pesquisa teve os seguintes objetivos:

\footnotetext{
${ }^{1}$ Disponível em:

http://portalsaude.saude.gov.br/index.php?option=com_content\&view=article\&id=9883\&catid=213\&lte $\mathrm{mid}=25$. Acessado em 05.fev. 2016.
} 


\subsubsection{Objetivo Geral:}

- Propor um modelo de otimização do Processo de aquisição de medicamentos na Rede Municipal de Saúde de Manaus.

\subsubsection{Objetivos Específicos:}

- Mapear o Fluxo Operacional da Gestão da Cadeia de Suprimentos de medicamentos.

- Mapear o Fluxo de Valor Presente do Processo de aquisição de medicamentos.

- Identificar as restrições e propor um Mapa de Valor Futuro para aquisição de medicamentos.

- Apresentar sugestões de melhorias no Processo de distribuição de medicamentos.

- $\quad$ Apresentar Painel de Indicadores para Gerenciar o Processo de aquisição de medicamentos.

\subsection{JUSTIFICATIVA}

No ano de 2010, a Secretaria Municipal de Saúde de Manaus, teve uma dotação orçamentária para a Assistência Farmacêutica no valor de $R \$ 8.767 .932,32$. Em 2011 a dotação foi de $\mathrm{R} \$ 18.354 .963,59$ (incremento de 109,34\%). Em $2012^{2}$ a dotação foi de $R \$ 25.966 .359,18$ (incremento de 41,47\%). Interrompendo a série crescente, em 2013, a dotação foi de $R \$ 20.462 .649,73$ (decréscimo de 21,20\% em relação ao ano anterior). No ano de 2014 a dotação da Assistência Farmacêutica foi

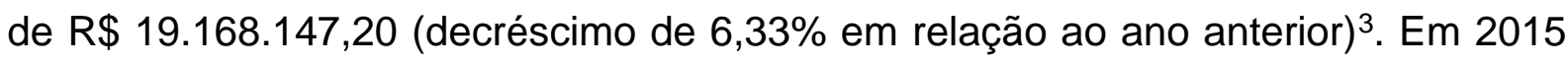
houve um incremento da ordem de $70,46 \%$ sobre o valor do ano anterior, tendo a Assistência Farmacêutica uma dotação de $\mathrm{R} \$ 32.674 .397,56^{4}$.

De acordo com os dados disponíveis, de 2010 a 2015 a Administração Pública designou $R \$ R \$ 125.394 .449,58$ (cento e vinte e cinco milhões, trezentos e noventa e quatro mil, quatrocentos e quarenta e nove reais e cinquenta e oito

\footnotetext{
2 Ofício no 1468/2015-LAI/OUVMSUS/GABIN/SEMSA de 10 de abril de 2015

${ }^{3}$ Portal de Acesso à Informação ao Cidadão. Relatório de Gestão Anual da SEMSA. Disponível em HTTP:// aocidadao.manaus. am. gov.br/semsa/relatorios-de-gestao. Acessado em: 13.02.2016. Os Relatórios de 2012 e 2015 não foram divulgados no Portal

${ }^{4}$ Departamento de Planejamento - DEPLAN/SEMSA
} 
centavos) para a Assistência Farmacêutica, recurso este usado prioritariamente para aquisição de medicamentos e insumos para a saúde ${ }^{5}$.

Gráfico 1 - Dotação Orçamentária Assistência Farmacêutica

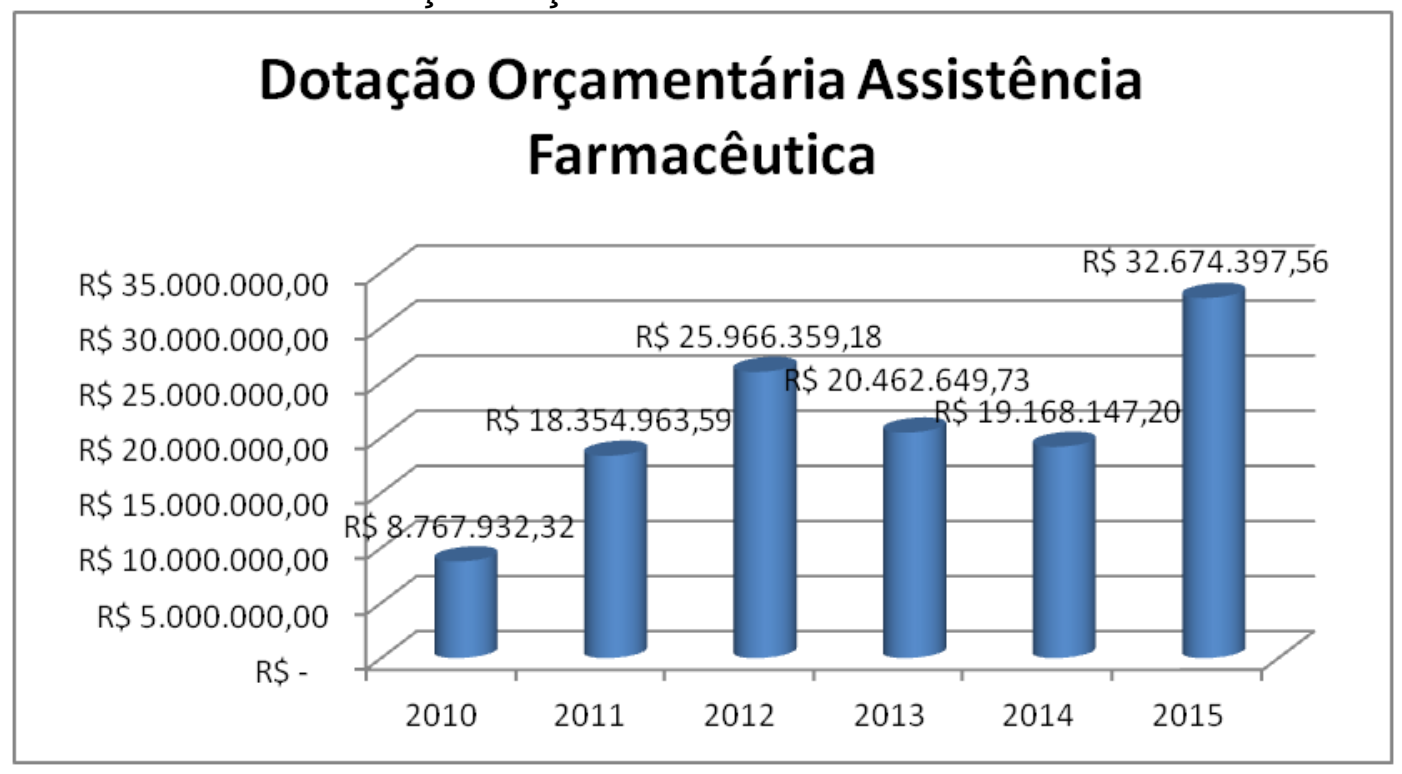

Fonte: Elaborado pelo Autor, 2017.

A aplicação e o desenvolvimento dos conceitos, métodos e processos da Gestão da Cadeia de Suprimentos na gestão dos medicamentos e insumos para a saúde no âmbito da Secretaria Municipal de Saúde trará resultados relevantes para a Administração Pública.

A montante, nos processos de aquisição de medicamento, com toda a rede de fornecedores na busca ativa de adquirir produtos com qualidade, baixo custo, rapidez e segurança, desenvolvendo um canal de comunicação entre todos os stakeholders, e a jusante, ofertando a clientela do SUS o medicamento certo, no tempo e local adequado (BALLOU, 2006; MACHLINE, 2011; SIMON et al., 2015).

Segundo o Council of Supply Chain Management Professionals ${ }^{6}$ (2016), Gestão da Cadeia de Suprimentos é o planejamento e gerenciamento de todas as atividades envolvidas na aquisição, fornecimento e transformação. Inclui também todas as atividades de gestão da logística. Coordenação e colaboração com parceiros de canal (fornecedores, intermediários, prestadores de serviços de terceiros e clientes). Em essência, a Gestão da Cadeia de Suprimentos integra a

\footnotetext{
5 Prioritariamente mas não essencialmente, pois o recurso também pode ser sado para aquisição de patrimônio, por exemplo, instrumental odontológico ou equipamento hospitalar/ambulatorial.

${ }^{6}$ Disponível em: https://cscmp.org/supply-chain-management-definitions Acessado em 17.02.2016
} 
gestão da oferta (output) e gestão da demanda (input) dentro e entre Empresas (BALLOU, 2006; WANKE; CORRÊA, 2014).

Souza (2015), a despeito da Gestão da Cadeia de Suprimentos de medicamentos, empreendida pela Administração dos Laboratórios Públicos (Estaduais e Federais), enfatiza a importância da Gestão da Cadeia de Suprimentos para o êxito da complexa e emblemática produção e distribuição de medicamentos no País.

No que tange a Administração Pública, que não tem fins lucrativos, sua lucratividade advém da economicidade. Quanto menor o custo nas aquisições maior economia para o erário Público. De forma similar, quanto menor o custo envolvido na aquisição de medicamentos e insumos para a saúde, maior economia para a SEMSA.

Como visto, o orçamento designado para aquisição de medicamentos na SEMSA é expressivo. Neste quesito, uma gestão eficiente da Cadeia de Suprimentos indubitavelmente irá corroborar na gestão de custos, proporcionando economia para o Município.

A gestão de custos está na gênesis da Gestão da Cadeia de Suprimentos. Ballou (2006) é tácito ao afirmar que no passado o foco da logística era sobre a eficiência (produto certo, entregue no local certo, para a pessoa certa). Hoje com o aumento da globalização, terceirização da produção e exportação, a ênfase está na concepção e operação da Cadeia de Suprimentos, melhorando as receitas, diminuindo os custos e maximizando o lucro.

Guerreiro (2011) e Tridapalli (2011) corroboram com Ballou (2006) sobre a importância da Gestão da Cadeia de Suprimentos na gestão de custos. De maneira especial, Tridapalli (2011) demonstra na esfera do Setor Público, como a Gestão da Cadeia aliada a Tecnologia da Informação podem trazer resultados extremamente satisfatórios para a Administração Pública.

Conforme se pode perceber em publicações especializadas, é vasta a literatura demonstrando como a Engenharia de Produção tem contribuído significativamente para o crescimento e desenvolvimento de muitas Empresas, tendo seus conceitos e métodos amplamente disseminando no Setor Privado.

No Setor Público são poucos os trabalhos científicos demonstrando as melhorias promovidas com o auxílio da Engenharia de Produção. Especificamente sobre o 
tema Gestão da Cadeia de Suprimentos no Setor Público, Tridapalli (2011) afirma que há uma escassez de pesquisas científicas nesta área.

Numa análise macro, pode-se observar que a Engenharia de Produção tem muito a contribuir com a Administração Pública através de sua metodologia de gestão e ferramentas de trabalho, sempre em busca da eficiência e eficácia, aumento da produtividade e diminuição dos custos, proporcionando produtos/serviços com qualidade ao cliente final.

Para a Secretaria Municipal de Saúde de Manaus será uma pesquisa com grande relevância, pois irá mensurar de forma epistemológica os processos de trabalho na gestão de aquisição de medicamentos, eliminando as mudas e propondo melhorias na cadeia. Fato este que terá um grande beneficiário: o usuário final do SUS ao ter sua demanda de medicamentos atendida, com baixo custo para o erário do município.

\subsection{ESTRUTURA DO TRABALHO}

Esta pesquisa está estruturada em 6 capítulos. O capítulo 1 é a Introdução, onde é apresentada a questão norteadora da pesquisa, problematização, objetivos e justificativa para realização da mesma. O capítulo 2 aborda a Revisão da Literatura sobre a temática, aprofundando o estado da arte sobre o tema, trazendo a tona o pensamento de vários autores através de artigos científicos publicados nos últimos cinco anos, além do pensamento de autores clássicos na área de Engenharia de Produção e Gestão da Cadeia de Suprimentos. O capítulo 3 demonstra os Procedimentos Metodológicos que serviram de base epistemológica na condução da pesquisa, levantamento e tratamento dos dados, bem como construção dos resultados. O capítulo 4 demonstra o Estudo de Caso propriamente dito, onde são apresentados os resultados da pesquisa sobre a Gestão da Cadeia de Suprimentos de Medicamentos no âmbito da Secretaria Municipal de Saúde de Manaus (SEMSA). O capítulo 5 apresenta as considerações finais, seguido pelas Referências Bibliográficas no capítulo 6. 


\section{REVISÃO DA LITERATURA}

Estimativas do Fundo Monetário Internacional (FMI) indicam que o custo com operações de logística representam doze por cento (12\%) do Produto Interno Bruto (PIB) mundial ao ano (BALLOU, 2001; DEY et al., 2011). Outro dado relevante é o volume de cargas no modal marítimo que vem apresentando aumento significativo nos últimos anos, saindo de 2,6 bilhões de toneladas em 1970 para 9,5 bilhões de toneladas em 2013 (VANELSLANDER; MUSSO, 2015). Ballou (2006) afirma que até 2020 , oitenta por cento $(80 \%)$ de tudo o que for produzido no mundo, será consumido num país diferente de sua origem.

Estes dados indicam uma revolução no campo da logística mundial (VANELSLANDER; MUSSO, 2015). Fatores como globalização, livre comércio, terceirização (MENTZER, 2001; BALLOU, 2006; MACHLINE, 2011), melhoras no processo de produção, novas demandas de consumo (BALLOU, 2006), desenvolvimento de novas tecnologias (NOGUEIRA NETO; SACOMANO, 2010; DOLCl; MAÇADA, 2014), necessidade de baixar custos (BALLOU, 2006; GUERREIRO, 2011; TRIDAPALLI et al., 2011), relações mais estreitas com fornecedores (MENTZER, 2001) e principalmente, atender as necessidade do cliente final cada vez mais exigente (MENTZER, 2001; WANKE; CORRÊA, 2014), exigiram das Empresas uma nova forma de gestão.

Gestão focada nos processos de negócio e não apenas nos processos logísticos (SANTOS; ALVES, 2015). Onde desde o fornecedor primário até o cliente final são contemplados. Uma gestão macro, holística, sistêmica, integrada em cadeia. É neste ambiente que os conceitos da Supply Chain Management (SCM) ou Gestão da Cadeia de Suprimento (GCS) serão desenvolvidos e implementados (COOPER et al., 1997; HARLAND et al., 1999; TALAMINI et al., 2005; BALLOU, 2006; MACHLINE, 2011; SANTOS; ALVES, 2015).

\subsection{GESTÃO DA CADEIA DE SUPRIMENTOS (GCS)}

Ballou (2006) diz que a origem do nome Supply Chain Management (SCM) é um mistério. Cooper et al. (1997), Lummus e Vokurka (1999), Chen e Paulraj (2004), Talamini et al. (2005) e Cerra et al. (2014) afirmam que o termo apareceu pela primeira vez na literatura no início da década de 1980, e somente na década de 
1990 a literatura acadêmica demonstrou seu fundamento teórico e pressupostos metodológicos, principalmente diferenciando Supply Chain Management de Logística/Logística Integrada7.

Cooper et al. (1997) afirma tacitamente que Gestão da Cadeia de Suprimentos (GCS) e logística têm processos diferentes. A logística é um processo da Gestão da Cadeia de Suprimentos, exercido dentro da Empresa Focal. A Gestão da Cadeia de Suprimentos abrange gestão de fluxo de processos de várias Empresas, desde os fornecedores primários (a montante) até o consumidor final (a jusante), com seu gerenciamento a partir da Empresa Focal (TALAMINI et al., 2005; SANTOS; ALVES, 2015).

Segundo o Council of Supply Chain Management Professionals ${ }^{8}$ (2016), Gestão da Cadeia de Suprimentos é o planejamento e gerenciamento de todas as atividades envolvidas na aquisição, transformação e fornecimento. Inclui também todas as atividades de gestão da logística. Coordenação e colaboração com parceiros de canal (fornecedores, intermediários, prestadores de serviços de terceiros e clientes). Em essência, a Gestão da Cadeia de Suprimentos integra gestão da demanda (input) a gestão da oferta (output) dentro e entre Empresas (COOPER et al., 1997; HARLAND et al., 1999; TALAMINI et al., 2005; BALLOU, 2006; WANKE; CORRÊA, 2014).

Outras definições correlatas na literatura corroboram para o entendimento do conceito de Gestão da Cadeia de Suprimentos, com destaque para a evolução da percepção que os autores têm ao longo do tempo sobre a GCS, como pode ser visto no Quadro 1.

\footnotetext{
${ }^{7}$ Tomando como referência a Annual Conference of the Council of Logistics Management, realizada nos Estados Unidos, em 1995 13,5\% dos trabalhos apresentados continha a expressão "cadeia de suprimentos" no título. Em 1997, este percentual subiu para 22,4\% (MENTZER et al. 2001).

${ }^{8}$ Disponível em: https://cscmp.org/supply-chain-management-definitions Acessado em 17.02.2016.
} 
Quadro 1 - Definições: Gestão da Cadeia de Suprimentos

\begin{tabular}{|c|c|}
\hline Autor & Definição \\
\hline Santos, Alves (2015) & $\begin{array}{l}\text { É o gerenciamento de toda a cadeia de suprimento, a partir da Empresa } \\
\text { Focal, abrangendo todo o fluxo de transformação do produto, focando nos } \\
\text { processos de negócio relacionados aos requisitos dos clientes finais, } \\
\text { visando alcançar vantagem competitiva, adicionando valor na visão dos } \\
\text { clientes e demais stakeholders. }\end{array}$ \\
\hline Souza (2015) & $\begin{array}{l}\text { É gestão de todas as atividades associadas à logística interna e } \\
\text { interorganizacional, bem como a coordenação e colaboração entre todos } \\
\text { os parceiros da cadeia, sejam eles fornecedores, prestadores de serviço ou } \\
\text { consumidores. }\end{array}$ \\
\hline Simon et al. (2015) & $\begin{array}{l}\text { É a integração de processos de negócios-chave do usuário final por meio } \\
\text { de fornecedores primários que fornecem produtos, serviços e informações } \\
\text { que agregam valor para os clientes e outras partes interessadas. }\end{array}$ \\
\hline Cerra (2014) & $\begin{array}{l}\text { E a integração de processos de negócios-chave do usuário final até os } \\
\text { fornecedores originais que proveem produtos, serviços e informação que } \\
\text { adicionam valor para os clientes e para os stakeholders. }\end{array}$ \\
\hline $\begin{array}{l}\text { Wanke, Corrêa } \\
\text { (2014) }\end{array}$ & $\begin{array}{l}\text { Quadro que integra a logística e redes de distribuição, operações de } \\
\text { produção e atividades de suprimentos dentro e entre Empresas. }\end{array}$ \\
\hline Machline (2011) & $\begin{array}{l}\text { Cadeia de suprimento abrange todos os esforços envolvidos na produção e } \\
\text { na entrega de um produto final desde o fornecedor do fornecedor até o } \\
\text { cliente do cliente. }\end{array}$ \\
\hline Ballou (2006) & $\begin{array}{l}\text { É o planejamento e gerenciamento de todas as atividades envolvidas no } \\
\text { fornecimento e aquisição, conversão e todas as atividades de gestão de } \\
\text { logística. A coordenação e colaboração com parceiros de canal, que } \\
\text { podem ser fornecedores, intermediários, prestadores de serviços de } \\
\text { terceiros e clientes. Em essência, GCS integra a oferta e a gestão da } \\
\text { demanda dentro e entre Empresas. }\end{array}$ \\
\hline Mentzer et al. (2001) & $\begin{array}{l}\text { É a coordenação sistemática e estratégica das funções de negócios } \\
\text { tradicionais e as táticas, em toda as funções de negócios dentro de uma } \\
\text { determinada Empresa e em todos os negócios dentro da cadeia de } \\
\text { fornecimento, para os fins de melhorar o desempenho de longo prazo das } \\
\text { Empresas individuais e a cadeia de suprimentos como um todo. }\end{array}$ \\
\hline $\begin{array}{l}\text { Lummus, Vokurka } \\
\text { (1999) }\end{array}$ & $\begin{array}{l}\text { Todas as atividades envolvidas na entrega de um produto desde a matéria } \\
\text { prima até o cliente, incluindo o suprimentos de matérias-primas e peças, } \\
\text { fabricação e montagem, armazenagem e controle de estoque, entrada de } \\
\text { pedidos e gerenciamento de pedidos, distribuição em todos os canais, } \\
\text { entrega ao cliente, e os sistemas de informação necessários para monitorar } \\
\text { todas essas atividades. }\end{array}$ \\
\hline Cooper et al. (1997) & $\begin{array}{l}\text { É a integração de processos de negócios do usuário final através de } \\
\text { fornecedores iniciais que fornecem produtos, serviços e informações que } \\
\text { agregam valor para os clientes. }\end{array}$ \\
\hline
\end{tabular}

Fonte: Elaborado pelo auto, 2017.

De acordo com estas definições, a Gestão da Cadeia de Suprimentos é uma nova concepção para o gerenciamento estratégico-operacional de uma Organização (pública ou privada), integrando processos de trabalho, unificando canais de comunicação, aplicando novas ferramentas de Tecnologia da Informação (TI) e agregando valor aos fluxos dos parceiros (clientes e fornecedores) numa única cadeia, como se fosse uma grande linha de produção puxada (pull system).

Publicações especializadas indicam a existência de vários modelos conceituais da Gestão da Cadeia de Suprimentos (SIMON et al., 2015), entretanto, 
Lambert et al. (1998), Talamini et al. (2005), Ballou (2006) $)^{9}$, Gonzalez e Souza $(2010)^{10}$, Santos e Alves (2015) e Simon et al. (2015) apontam o modelo proposto por Cooper et al. (1997) como paradigma da Gestão da Cadeia de Suprimentos, com grande aceitação e aplicação no setor privado, sendo este modelo com as adequações de Lambert et al. (1998) e Lambert $(2004,2010)$ o mais difundido na literatura e entre gestores da Gestão da Cadeia de Suprimentos.

O modelo de Cooper et al. (1997) baseia-se em três pontos para Gestão da Cadeia de Suprimentos: (1) Processos de Negócios; (2) Estrutura da Cadeia de Suprimentos; (3) Componentes de Gestão, como pode ser visto na Figura 1. Segundo Cooper et al. (1997) com esta estrutura, a filosofia da SCM preenche a lacuna existente entre os teóricos da SCM (Academia) e os profissionais da SCM (Organizações).

Figura 1 - Modelo de Gestão Cadeia de Suprimentos

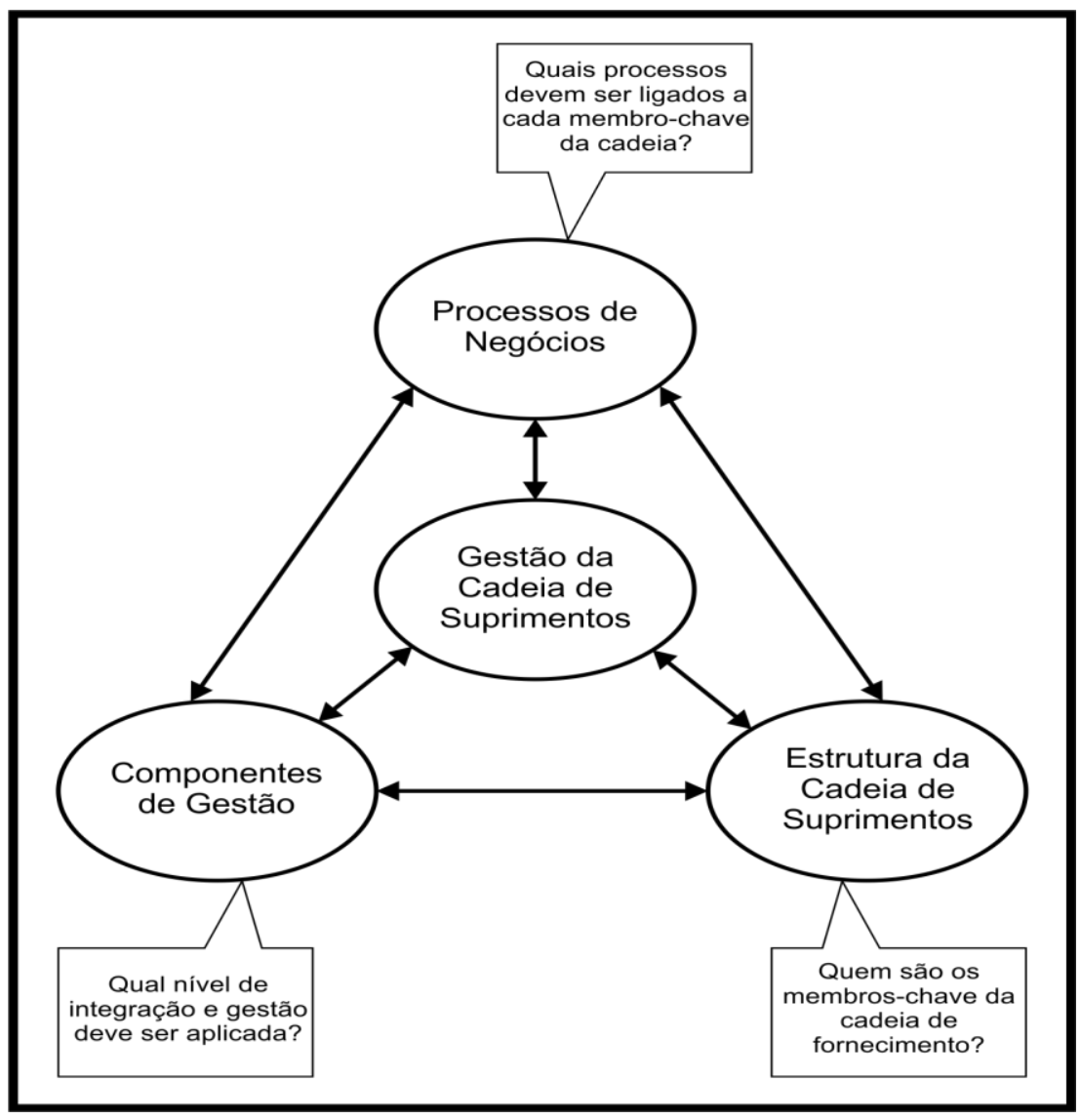

Fonte: Adaptado de Cooper et al.,1997; Lambert et al., 1998.

\footnotetext{
${ }^{9}$ Ballou (2006) faz referência a Lambert et al. (1998), que por sua vez usa Cooper et al. (1997).

${ }^{10}$ No que tange aos Processos de Negócios, usam Cooper et al. (1997)
} 


\subsubsection{Processos de Negócios}

Processo é uma atividade ou conjunto de atividades que toma uma entrada (input), agrega valor e fornece uma saída (output) específica para um cliente, sendo realizadas numa sequência lógica, estruturada e organizada (COOPER et al., 1997; LAMBERT et al., 1998; GONÇALVES, 2000).

É uma ordenação específica de atividades com uma entrada (input) e uma saída (output) claramente identificadas, com uma estrutura de ação entre a entrada e a saída (processamento ou transformação), com um produto final acabado (COOPER et al., 1997; LAMBERT et al., 1998). Os inputs podem ser materiais, equipamentos, bens tangíveis ou informações e conhecimento (GONÇALVES, 2000). A Figura 2 ilustra a definição de Processo ${ }^{11}$.

Figura 2 - Fluxo do Processo

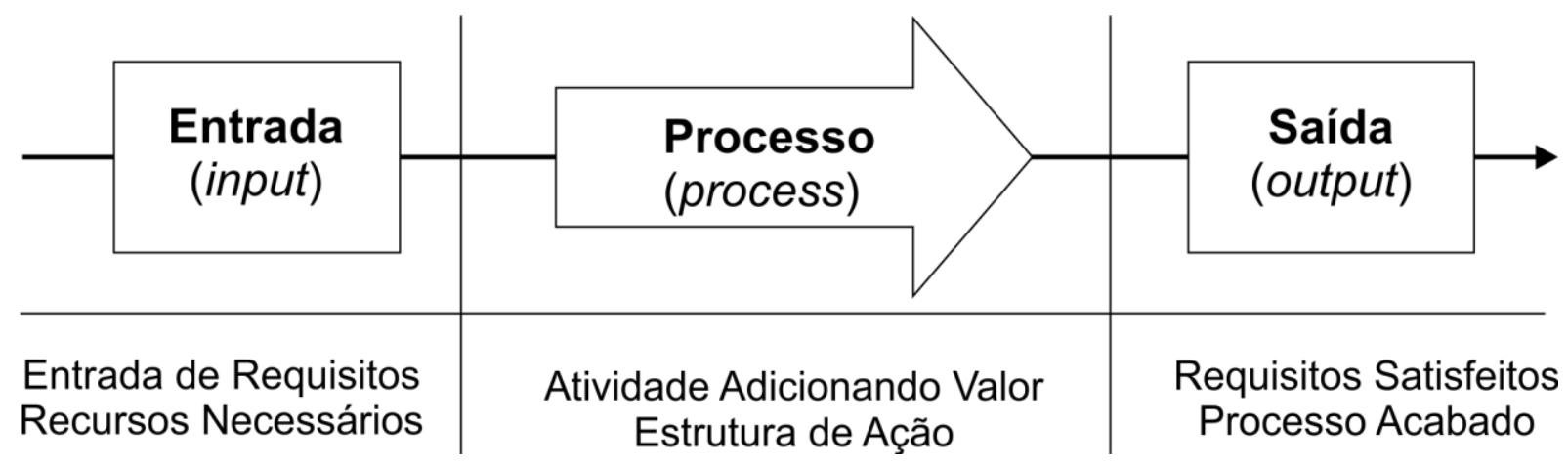

Fonte: Elaborado pelo autor, 2017.

Santos e Alves (2015) destacam as mudanças de gestão ocorridas nas Corporações. Na década de 1980, a gestão departamental deu lugar à gestão por processos. Na década de $90 \mathrm{com}$ a cadeia de suprimentos, a gestão de processos passou a ser interorganizacional, visando integrar os processos de negócio da cadeia de suprimentos.

Uma vez que uma ou mais Empresas (públicas ou privadas) têm ligações de processos de negócios com outras Empresas, essas ligações passam a formar um

\footnotetext{
${ }^{11}$ É importante destacar a diferença entre Processo como conjunto de atividades com uma entrada e uma saída, com um produto acabado de Processo Administrativo, utilizado no âmbito da Administração Pública como instrumento burocrático na tramitação de documentos ou informações. Para fins didáticos e melhor entendimento desta pesquisa, todas as referências a processos no âmbito da Administração Pública será grafado como "Processo Administrativo" a fim de diferenciar outro processo.
} 
elo que pode ser concebido como uma rede entre Empresas, formando assim, uma cadeia, no caso, uma cadeia de suprimentos (LAMBERT et al., 1998). Os processos de negócios da cadeia de suprimentos cruzam as fronteiras organizacionais, independentemente da estrutura formal (COOPER et al., 1997).

Cooper et al. (1997) identificou sete processos de negócios chave na gestão da cadeia de suprimento. Lambert $(2004,2010)$ fez adequações/atualizações nestes processos, e propôs oito processos de negócios chave: (1) Gestão de Relacionamento com o Cliente; (2) Gestão de Relacionamento com Fornecedor; (3) Gestão de Serviço ao Cliente; (4) Gestão da Demanda; (5) Cumprimento da Ordem; (6) Gestão do Fluxo de Produção; (7) Desenvolvimento e Comercialização de Produtos; (8) Gerenciamento de Devoluções, conforme pode ser observado na Figura 3.

Figura 3 - Processos de Negócios Através da Cadeia de Suprimentos

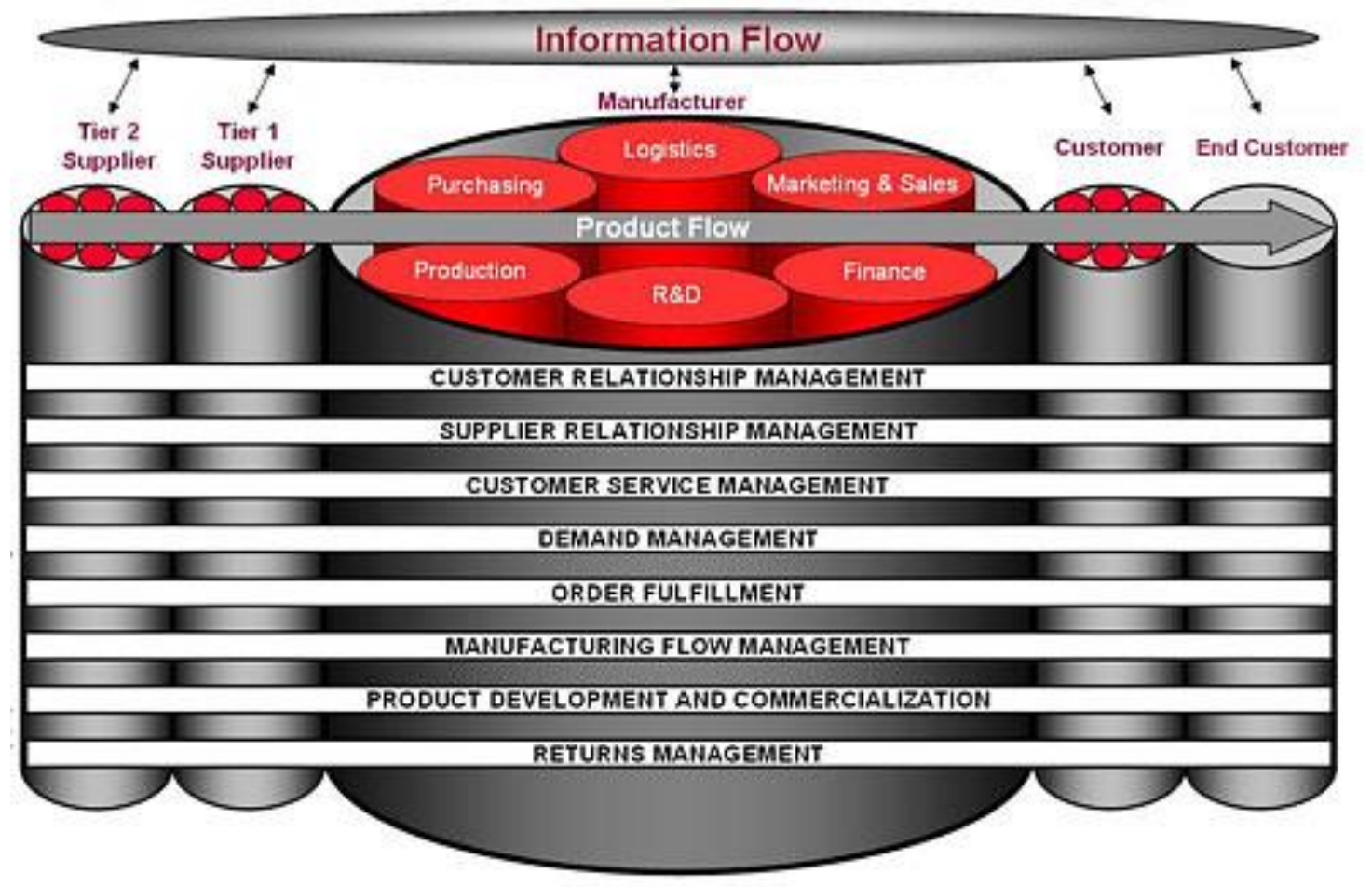

Fonte: Lambert et al., 1998; Lambert, 2004, 2010.

Gestão de Relacionamento com o Cliente envolve a identificação de mercado para clientes-chaves, e a implementação de programas com estes clientes (COOPER et al.,1997). O objetivo é segmentar os clientes com base no seu valor ao 
longo do tempo e fidelizar os clientes com fornecimento de produtos e serviços personalizados (LAMBERT, 2004, 2010).

Gestão de Relacionamento com Fornecedor é a estrutura de como os relacionamentos com os fornecedores será desenvolvida e mantida. Relações estreitas serão desenvolvidas com um pequeno conjunto de fornecedores com base no valor que eles fornecem para a organização ao longo do tempo, e os relacionamentos mais tradicionais são mantidos com os outros (LAMBERT, 2004, 2010).

Gestão de Serviço ao Cliente fornece um rosto para o cliente usando sistemas de informação on-line com informações atuais sobre a ordem, bem como o status de produção e distribuição. Este processo também fornece informações sobre o produto ao cliente (COOPER et al., 1997).

Gestão da Demanda é o processo que equilibra os requisitos dos clientes com as capacidades da oferta em cadeia. Com este processo ajustado, a gestão pode equilibrar a oferta com a demanda de forma proativa e executar o plano com interrupções mínimas. O processo consiste em sincronizar oferta e demanda, aumentar a flexibilidade e reduzir a variabilidade (LAMBERT, 2004, 2010).

Cumprimento da Ordem é o processo que prevê a entrega precisas dos pedidos dos clientes, com o objetivo de não retardar as necessidades do cliente (COOPER et al., 1997). Inclui todas as atividades necessárias para definir os requisitos do cliente, projetar uma rede para atender suas solicitações e minimizar o custo total de entrega (LAMBERT, 2004, 2010).

Gestão do Fluxo de Produção é o processo que está diretamente relacionado em fazer os produtos que o cliente quer, resultando em processo de fabricação mais flexível e esforço para ter a combinação certa de produtos (COOPER et al., 1997).

Desenvolvimento e Comercialização de Produtos é o processo que fornece a estrutura para desenvolvimento e comercializar produtos em conjunto com os clientes e fornecedores (LAMBERT, 2004, 2010).

Gerenciamento de Devoluções envolve as atividades associadas com os retornos, logística reversa, manutenção e prevenção, e como eles são geridos dentro da Empresa e através de membros-chave da cadeia de suprimento. A aplicação correta deste processo permite identificar oportunidades de redução de retornos indesejáveis e controlar ativos reutilizáveis. Em muitas indústrias, um 
processo de gestão retornos eficaz proporciona uma oportunidade para alcançar uma vantagem competitiva sustentável (LAMBERT, 2004, 2010).

Tomados em conjunto, esses processos representam a Gestão da Cadeia de Suprimentos na sua totalidade. Eles devem ser coordenados através da colaboração e gestão de relacionamento ao longo dos vários escalões do canal de suprimentos, desde os fornecedores iniciais para os consumidores finais (BALLOU, 2006).

\subsubsection{Estrutura da Cadeia de Suprimentos}

A estrutura da cadeia de suprimentos envolve uma rede. No sentido a montante (upstream) com todos os fornecedores de vários níveis, e no sentido a jusante (downstream) com todos os clientes, até chegar ao cliente final. $\mathrm{Na}$ Gestão da Cadeia de Suprimentos está a Empresa Focal (TALAMINI et al., 2005; JABBOUR et al., 2013; SANTOS; ALVES, 2015), conforme por ser visto na Figura 4.

Figura 4 - Estrutura da Gestão da Cadeia de Suprimentos

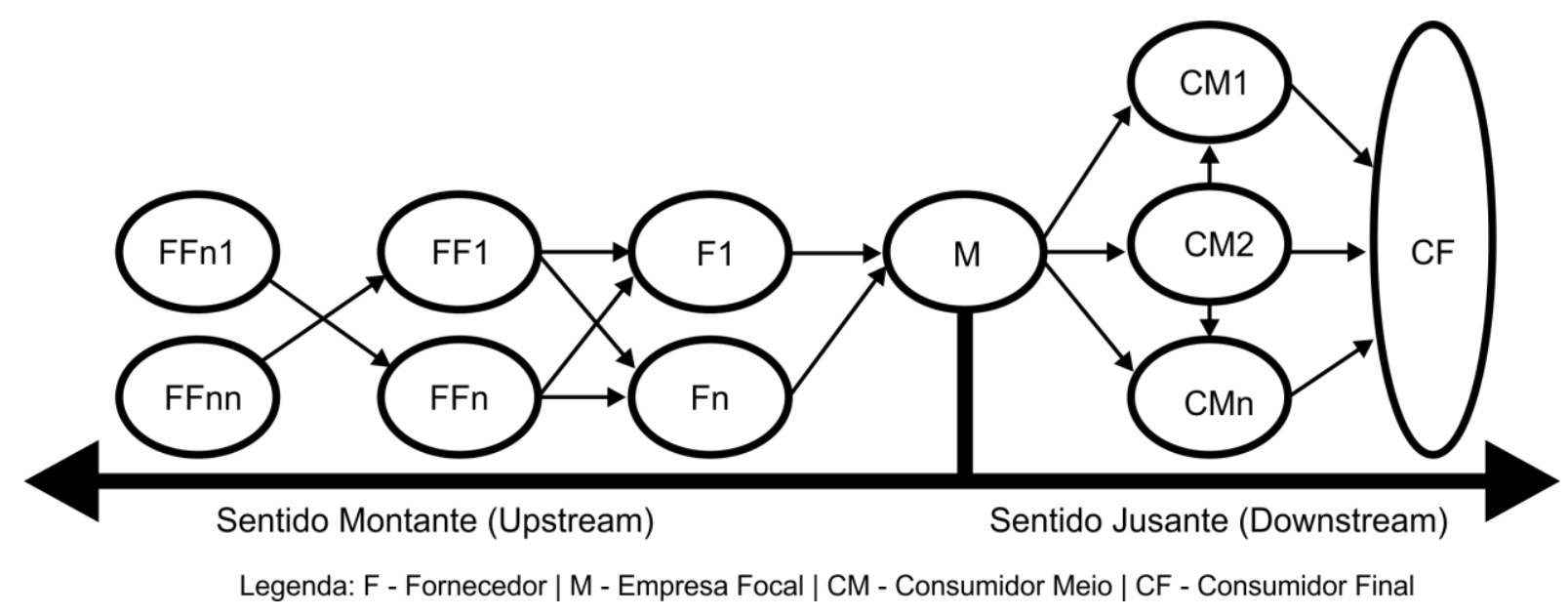

Fonte: Adaptado de Santos e Alves, 2015.

A Empresa Focal tem papel importante dentro da estrutura de uma cadeia de suprimentos (TALAMINI et al., 2005; JABBOUR et al., 2013; SANTOS; ALVES, 2015). Segundo Talamini et al. (2005) a Empresa Focal é a referência para diagnostico da cadeia de suprimentos, tanto no relacionamento com fornecedores quanto com clientes. É a partir dela que uma cadeia é analisada. 
A cadeia de suprimentos fica subordinada à demanda de produtos, bens ou serviços da Empresa Focal (SANTOS; ALVES, 2015). A forma como a cadeia de suprimentos é gerenciada e desenvolvida depende da estratégia da Empresa Focal (JABBOUR et al., 2013). Em síntese, a gestão da cadeia de suprimentos é feita a partir da Empresa Focal.

Lambert et al. (1998) é tácito ao afirmar que ter conhecimento explícito e entendimento de como a estrutura da cadeia de suprimentos está configurada é conditio sine qua non para a Gestão da Cadeia de Suprimentos. A estrutura da cadeia de suprimentos é composta pelas Empresas que participam do processo produtivo (TALAMINI et al., 2005).

Para tanto, Lambert et al. (1998) propõe três aspectos estruturais primários de uma rede/cadeia da Empresa: (1) Os membros da cadeia de suprimentos; (2) As dimensões estruturais da rede; (3) Os tipos de ligações de processos em toda a cadeia de suprimentos.

Os membros de uma cadeia de suprimentos são todas as Empresas (Instituições/Repartições/Setores) com as quais a Empresa Focal interage direta ou indiretamente por meio de seus fornecedores ou clientes, a partir do ponto de origem ao ponto de consumo (LAMBERT et al., 1998; TALAMINI et al., 2005). Devido à complexidade da cadeia e a possibilidade de existir grande número de membros, estes são classificados em membros primários ou membros de suporte/apoio (LAMBERT et al., 1998; TALAMINI et al., 2005).

Os membros primários são as Empresas que exercem atividades operacionais ou de gestão, diretamente envolvidas nos processos de negócios projetados para produzir uma saída (output) específica para o cliente (LAMBERT et al., 1998; TALAMINI et al., 2005).

Os membros de apoio são as Empresas que fornecem ativos, utilidades, conhecimento ou recursos para os membros primários (LAMBERT et al., 1998; TALAMINI et al., 2005).

As dimensões estruturais da rede são essenciais para gerenciar, descrever e analisar uma cadeia de suprimentos (LAMBERT et al., 1998). São três as dimensões: (1) A estrutura horizontal; (2) A estrutura vertical; (3) Posição horizontal da Empresa Focal (LAMBERT et al., 1998; TALAMINI et al., 2005).

A estrutura horizontal faz referência ao número de níveis existentes ao logo da cadeia. A estrutura vertical faz referência ao número de fornecedores ou clientes 
existentes em cada nível. A posição horizontal da Empresa Focal faz referência ao posicionamento físico da Empresa Focal, que pode ser próximo dos fornecedores, próximo dos clientes ou em algum ponto entre eles (LAMBERT et al., 1998; TALAMINI et al., 2005).

Segundo Lambert et al. (1998) existem diferentes tipos de ligações de processos interorganizacionais entre os membros da cadeia de suprimentos. Basicamente são quatro os tipos de ligação: (1) Processos gerenciado; (2) Processos monitorados; (3) Processos não gerenciados; (4) Processos com não membros.

Processos gerenciados (Managed Process Links) são as conexões (elos) estabelecidas entre a Empresa Focal e demais membros da cadeia, onde processos operacionais fundamentais para o negócio da Empresa Focal, são gerenciados, monitorados e integrados pela Empresa Focal (LAMBERT et al., 1998; TALAMINI et al., 2005).

Processos monitorados (Monitored Process Links) são as conexões (elos) estabelecidas entre a Empresa Focal e demais membros da cadeia, onde processos operacionais que não são fundamentais ou críticos para o negócio da Empresa Focal, são gerenciados por outros membros da cadeia, mas que são suficientemente importantes para a Empresa Focal manter um monitoramento (LAMBERT et al., 1998; TALAMINI et al., 2005).

Processos não gerenciados (Non-managed Process Links) são as conexões (elos) estabelecidas entre a Empresa Focal e demais membros da cadeia, onde processos operacionais que não são fundamentais ou críticos para o negócio da Empresa Focal, são gerenciados por outros membros da cadeia, sem o controle ou gerencia da Empresa Focal (LAMBERT et al., 1998; TALAMINI et al., 2005).

Processos com não membros (Non-member Process Link) são as conexões (elos) que eventualmente podem ser estabelecidas entre membros da cadeia com clientes/fornecedores de outra cadeia (LAMBERT et al., 1998; TALAMINI et al., 2005).

\subsubsection{Componentes de Gestão}

Componentes de Gestão são procedimentos gerenciais relacionados à gestão dos processos de negócio que são comuns entres os membros da cadeia de 
suprimento (COOPER et al., 1997; LAMBERT et al., 1998). Lambert et al. (1998) aponta que estes componentes de gestão são críticos e fundamentais para o sucesso da SCM, pois representam em essência como cada processo é interligado e gerido entre Empresas, dentro da estrutura da cadeia.

Lambert et al. (1998) baseado em revisão da literatura bem como entrevistas com gerentes de SCM, indica a existência de nove componentes de gestão da cadeia de suprimentos, estando divididos em dois grupos, conforme Quadro 2.

Quadro 2 - Componentes de Gestão

\begin{tabular}{|c|c|}
\hline Físicos e Técnicos & Gerenciais e Comportamentais \\
\hline Métodos de Planejamento e Controle & Métodos de Gestão \\
\hline $\begin{array}{c}\text { Fluxo de Trabalho } \\
\text { Estrutura de Atividade }\end{array}$ & Estrutura de Poder e Liderança \\
\hline Estrutura Organizacional & Estrutura de Risco e Recompensa \\
\hline $\begin{array}{c}\text { Facilidade Estrutural no Fluxo de } \\
\text { Informação e Comunicação }\end{array}$ & Cultura e Atitude \\
\hline $\begin{array}{c}\text { Facilidade Estrutural no Fluxo de } \\
\text { Produtos }\end{array}$ & - \\
\hline
\end{tabular}

Fonte: Adaptado de Lambert et al., 1998.

Os Componentes de Gestão Físicos e Técnicos são os componentes visíveis, palpáveis, mensuráveis, mais fáceis de serem modificados ou corrigidos (COOPER et al., 1997; LAMBERT et al., 1998; SIMON; PIRES, 2003), estão diretamente relacionados a estrutura de trabalho e procedimentos operacionais da Empresa. Se este grupo for o único foco da atenção gerencial, a gestão da cadeia de suprimentos provavelmente irá fracassar (LAMBERT et al., 1998). De modo sucinto, os componentes de gestão deste grupo são apresentados abaixo.

Métodos de Planejamento e Controle são as chaves para mover uma organização ou cadeia de suprimentos em uma direção desejada (COOPER et al., 1997). Têm relação com as ferramentas e técnicas utilizadas pelas Empresas (SIMON; PIRES, 2003).

Fluxo de Trabalho/Estrutura de Atividade sugere como a Empresa realiza suas tarefas e atividades (COOPER et al., 1997; SIMON; PIRES, 2003), tem relação com o fluxo operacional, com o fluxograma da organização. 
Estrutura Organizacional refere-se à estrutura interna da Empresa ou da cadeia de suprimentos (COOPER et al., 1997; SIMON; PIRES, 2003). Tem relação com o organograma, a estrutura de comando e liderança.

Facilidade Estrutural no Fluxo de Informação e Comunicação refere-se ao tipo de informação transmitida entre os membros do canal e a frequência de atualização das informações que têm forte influência sobre a eficiência da cadeia de suprimentos (COOPER et al., 1997; SIMON; PIRES, 2003).

Facilidade Estrutural no Fluxo de Produtos refere-se à estrutura de rede para a execução das atividades de sourcing e distribuição por toda a cadeia de suprimentos (SIMON; PIRES, 2003).

Já os Componentes de Gestão Gerenciais e Comportamentais são menos tangíveis, difíceis de avaliar e, principalmente, difíceis de modificar. Entretanto, os Componentes Gerenciais e Comportamentais ditam o comportamento organizacional da Empresa e têm influência direta sobre a forma como os componentes de gerenciamento físico e técnico são implementados (COOPER et al., 1997; LAMBERT et al., 1998). De modo sucinto, os componentes de gestão deste grupo são apresentados abaixo.

Métodos de Gestão compreendem a filosofia organizacional, as técnicas de gestão da organização (COOPER et al., 1997; SIMON; PIRES, 2003).

Estrutura de Poder e Liderança refere-se a questões relacionadas ao exercício do poder ou a falta dede, que pode comprometer o envolvimento entre os membros da cadeia (COOPER et al., 1997; SIMON; PIRES, 2003).

Estrutura de Risco e Recompensa considera que o compartilhamento de riscos e recompensas, de forma antecipada, em toda a cadeia de suprimentos, produzirá em longo prazo uma alta no nível de compromisso entre os membros da cadeia (COOPER et al., 1997; SIMON; PIRES, 2003).

Cultura e Atitude referem-se à cultura organizacional da Corporação, em especial como a cultura organizacional de várias Empresas serão geridas entre todos os membros da cadeia de suprimentos. Os aspectos da cultura incluem como os empregados são valorizados e como eles são incorporados à gestão da Empresa (COOPER et al., 1997; SIMON; PIRES, 2003). 


\subsection{COMPRAS PÚBLICAS}

A Constituição Federal de 1988, em seu Artigo 37, inciso XXI, estabelece a licitação pública como modus operandi para as compras públicas, ou seja, a contratação de obras, serviços, compras e alienações no âmbito da Administração Pública, direta e indireta, nos três Poderes, bem como União, Estados, Municípios e Distrito Federal (BRASIL, 1988). Devidamente regulamentada pela Lei ํㅡ 8.666, de 21 de junho de 1993, que institui as normas sobre os processos licitatórios da Administração Pública (BRASIL, 1993).

Uma compra bem sucedida significa comprar bens e serviços na quantidade e qualidade certa, no momento certo, ao preço mais econômico possível para a Administração Pública (TRIDAPALLI et al., 2011).

\subsubsection{Licitação}

O Tribunal de Contas da União define licitação como o procedimento administrativo formal em que a Administração Pública convoca, por meio de condições estabelecidas em ato próprio (edital ou convite), Empresas que desejam apresentar propostas para o oferecimento de bens e serviços para a Administração Pública (BRASIL, 2010).

Seu objetivo é proporcionar maior economia para a Administração Pública selecionando a proposta mais vantajosa, assegurando oportunidades iguais a todos os interessados e possibilitando o comparecimento ao certame do maior número possível de Empresas concorrentes (BRASIL, 1993, 2010).

A fim de assegurar igualdade e oportunidade às Empresas, os procedimentos licitatórios devem ser balizados por princípios que orientam toda atividade da Administração Pública (BRASIL, 2014a), conforme observado no Quadro 3. 
Quadro 3 - Princípios da Administração Pública

\begin{tabular}{|l|l|}
\hline \multicolumn{1}{|c|}{ Base Legal } & \multicolumn{1}{|c|}{ Princípios } \\
\hline Constituição Federal 1988 & $\begin{array}{l}\text { Legalidade, impessoalidade, moralidade, } \\
\text { publicidade e eficiência. }\end{array}$ \\
\hline Lei no 8.666/1993 & $\begin{array}{l}\text { Probidade administrativa, da vinculação ao } \\
\text { instrumento convocatório, do julgamento objetivo e } \\
\text { dos que Ihes são correlatos. }\end{array}$ \\
\hline Lei no 9.784/1999 & $\begin{array}{l}\text { Finalidade, motivação, razoabilidade, } \\
\text { proporcionalidade, moralidade, ampla defesa, } \\
\text { contraditório, segurança jurídica, interesse público. }\end{array}$ \\
\hline Decreto no 3.555/2000 & $\begin{array}{l}\text { Celeridade, competitividade, justo preço, } \\
\text { seletividade e comparação seletiva das propostas. }\end{array}$ \\
\hline Decreto $\mathrm{n}^{\circ}$ 5.450/2005 & $\begin{array}{l}\text { Princípios correlatos da razoabilidade, } \\
\text { competitividade e proporcionalidade. }\end{array}$ \\
\hline
\end{tabular}

Fonte: Brasil, 2014a.

A legislação também estabelece modalidades para as licitações públicas (BRASIL, 1993). Modalidade é a forma específica de conduzir o procedimento licitatório, a partir de critérios definidos em Lei (BRASIL, 2010), conforme pode ser visto no Quadro 4. 
Quadro 4 - Modalidades de Licitação

\begin{tabular}{|c|c|c|c|c|c|c|}
\hline 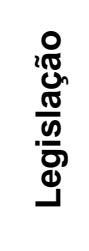 & $\begin{array}{l}\frac{0}{2} \\
\frac{\pi}{0} \\
\frac{\bar{Z}}{\pi} \\
\frac{\pi}{0} \\
\sum\end{array}$ & Definição & 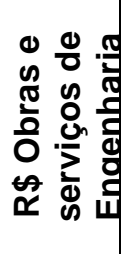 & 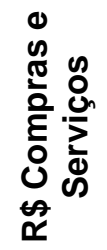 & 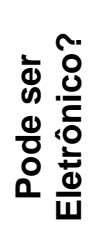 & 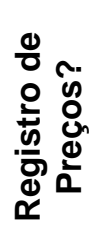 \\
\hline \multirow{5}{*}{ 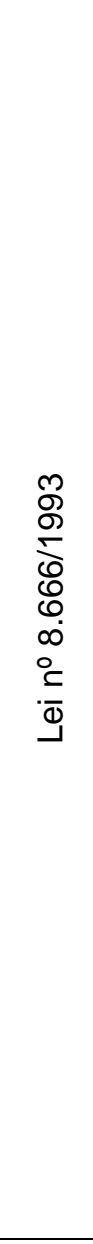 } & 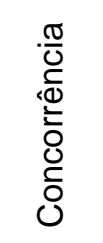 & $\begin{array}{l}\text { Modalidade de licitação entre quaisquer } \\
\text { interessados que, na fase inicial de habilitação } \\
\text { preliminar, comprovem possuir os requisitos } \\
\text { mínimos de qualificação exigidos no edital } \\
\text { para execução de seu objeto. }\end{array}$ & $\begin{array}{l}8 \\
8 \\
8 \\
\varnothing \\
\frac{1}{0} \\
\frac{0}{2}\end{array}$ & $\begin{array}{l}8 \\
8 \\
8 \\
8 \\
0 \\
\infty \\
.0 \\
\stackrel{0}{<}\end{array}$ & $\stackrel{200}{Z}$ & $\frac{E}{\tilde{\omega}}$ \\
\hline & 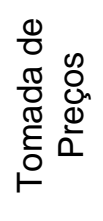 & $\begin{array}{l}\text { Modalidade de licitação entre interessados } \\
\text { devidamente cadastrados ou que atenderem a } \\
\text { todas as condições exigidas para } \\
\text { cadastramento até o terceiro dia anterior à } \\
\text { data do recebimento das propostas. }\end{array}$ & 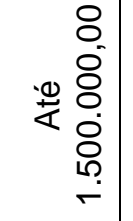 & 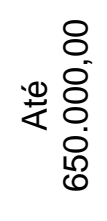 & 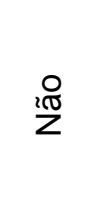 & $\stackrel{i \pi}{Z}$ \\
\hline & 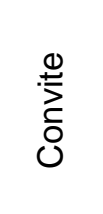 & $\begin{array}{l}\text { Modalidade de licitação entre interessados do } \\
\text { ramo pertinente ao seu objeto, cadastrados ou } \\
\text { não, escolhidos e convidados em número } \\
\text { mínimo de } 3 \text { (três) pela unidade administrativa. }\end{array}$ & 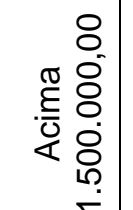 & 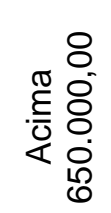 & $\stackrel{i \pi}{z}$ & $\frac{i \pi}{Z}$ \\
\hline & 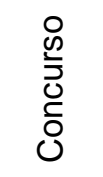 & $\begin{array}{l}\text { Modalidade de licitação entre quaisquer } \\
\text { interessados para escolha de trabalho técnico, } \\
\text { científico ou artístico, mediante a instituição de } \\
\text { prêmios ou remuneração aos vencedores. }\end{array}$ & \multicolumn{2}{|c|}{$\begin{array}{l}\text { Não se } \\
\text { aplica }\end{array}$} & i⿱乛龰 & $\frac{i \pi}{z}$ \\
\hline & $\frac{\frac{\pi}{0}}{\bar{\omega}}$ & $\begin{array}{l}\text { Modalidade de licitação entre quaisquer } \\
\text { interessados para a venda de bens móveis } \\
\text { inservíveis para a administração ou de } \\
\text { produtos legalmente apreendidos ou } \\
\text { penhorados, ou para a alienação de bens } \\
\text { imóveis. }\end{array}$ & \multicolumn{2}{|c|}{$\begin{array}{l}\text { Não se } \\
\text { aplica }\end{array}$} & $\stackrel{i \pi}{Z}$ & $\frac{i \pi}{2}$ \\
\hline 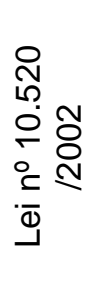 & 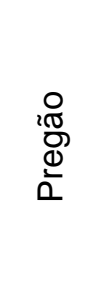 & $\begin{array}{l}\text { Modalidade de licitação realizada entre } \\
\text { interessados do ramo de que trata o objeto da } \\
\text { licitação que comprovem possuir os requisitos } \\
\text { mínimos de qualificação exigidos no edital, em } \\
\text { que a disputa pelo fornecimento de bens ou } \\
\text { serviços comuns é feita em sessão pública. } \\
\text { Pode ser presencial ou eletrônico. }\end{array}$ & 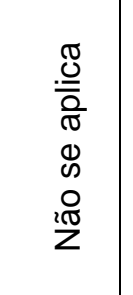 & $\begin{array}{l}\frac{\overline{0}}{\bar{N}} \\
\frac{1}{\bar{d}} \\
\frac{0}{0} \\
\frac{0}{0}\end{array}$ & के & $\frac{E}{\omega}$ \\
\hline
\end{tabular}

Fonte: Brasil, 1993, 2010, 2014a, 2014b.

Além das modalidades, a legislação também preconiza os tipos de licitação (BRASIL, 1993). Ambos não podem ser confundidos. A modalidade é procedimento. Tipos de licitação, segundo o Tribunal de Contas da União, são os critérios de julgamento utilizados pela Administração Pública para selecionar a proposta mais vantajosa (BRASIL, 2010). Segue abaixo Quadro 5 com os tipos de licitação. 
Quadro 5 - Tipos de Licitação

\begin{tabular}{|l|l|}
\hline \multicolumn{1}{|c|}{ Tipos } & \multicolumn{1}{c|}{ Descrição } \\
\hline Menor Preço & $\begin{array}{l}\text { O vencedor será o licitante que apresentar a proposta com o } \\
\text { menor preço dentre os licitantes considerados qualificados. }\end{array}$ \\
\hline Melhor Técnica & Serão avaliadas as características técnicas da contratação. \\
\hline Técnica e Preço ${ }^{12}$ & $\begin{array}{l}\text { A definição do vencedor se dará em função de critérios técnicos } \\
\text { e dos valores contidos na proposta. }\end{array}$ \\
\hline Maior Lance ou Oferta ${ }^{13}$ & $\begin{array}{l}\text { O vencedor será o licitante que apresentar a proposta ou o } \\
\text { lance com maior preço dentre os licitantes qualificados. }\end{array}$ \\
\hline
\end{tabular}

Fonte: Brasil, 1993, 2014a.

\subsubsection{O Sistema de Registro de Preços}

O Artigo 15, inciso II da Lei no 8.666, de 21 de junho de 1993, estabelece que as compras, sempre que possível, devem ser processadas através de Sistema de Registro de Preços (BRASIL, 1993; BRASIL, 2014c), sendo regulamentado pelo Decreto ํㅜ 7.892, de 23 de janeiro de 2013.

O Sistema de Registro de Preço ${ }^{14}$ é o conjunto de procedimentos adotados pela Administração Pública para registro formal de preços, para futuras aquisições, que viabiliza diversas contratações de compras, esporadicamente ou sucessivas, sem a necessidade de um novo processo licitatório para cada aquisição (BRASIL, 2010, 2013, 2014b).

Segundo o Tribunal de Contas da União, trata-s de um cadastro de produtos e fornecedores, selecionados mediante prévio processo licitatório, para eventual e futura contratação de bens e serviços (BRASIL, 2010, 2014c)

No sistema convencional, após a conclusão de todo o tramite do procedimento licitatório, independente da modalidade, o objeto da licitação é efetivado pela Administração Pública. É emitida uma Nota de Empenho e conforme prazo estipulado no Edital, o Fornecedor deve entregar o objeto da licitação.

\footnotetext{
12 Técnica e Preço e Melhor Técnica, devem ser utilizados na contratação de serviços de natureza predominantemente intelectual, em especial na elaboração de projetos, cálculos, fiscalização, supervisão e gerenciamento e de engenharia consultiva em geral.

${ }^{13}$ Tipo de licitação utilizado nos casos de alienação de bens e concessão de direito real de uso

${ }^{14}$ O Sistema de Registro de Preços não é uma Modalidade de licitação e nem um Tipo de licitação
} 
Já no Sistema de Registro de Preços, apenas as modalidades Concorrência e Pregão (conforme Quadro 4) podem ser utilizadas, e após a conclusão de todo o procedimento licitatório é gerado uma Ata de Registro de Preços. Após a publicação desta Ata de Registro de Preços no Diário Oficial, a Administração Pública pode fazer várias aquisições desta Ata ao longo de no máximo 12 meses, sem a necessidade de um novo procedimento licitatório, tornando o processo para aquisição/contratação menos burocrático e mais rápido (BRASIL, 2010, 2013).

Uma peculiaridade do Registro de Preços é que a Ata de Registro de Preços fica disponível para os órgãos e entidades participantes do registro, mas também para qualquer outro órgão ou entidade da Administração Pública, ainda que não tenha participado do processo licitatório (BRASIL, 2010).

O Tribunal de Contas da União (BRASIL, 2010) aponta algumas peculiaridades do Sistema de Registro de Preços, conforme Quadro 6.

\section{Quadro 6 - Peculiaridades do Registro de Preços}

\begin{tabular}{|c|}
\hline $\begin{array}{l}\text { A Administração não está obrigada a contratar o bem ou serviço registrado. } \\
\text { O licitante se compromete a manter o preço registrado e a disponibilidade do produto, } \\
\text { durante a validade do registro. }\end{array}$ \\
\hline $\begin{array}{l}\text { ação poderá realizar tantas contratações quantas se fizerem necessárias, } \\
\text { os prazos de validade e quantitativos estipulados. }\end{array}$ \\
\hline $\begin{array}{l}\text { A Administração pode realizar outra licitação para a contratação pretendida, a despeito } \\
\text { da existência de preços registrados. Contudo, não pode comprar de outro licitante que } \\
\text { não o ofertante a melhor proposta. }\end{array}$ \\
\hline $\begin{array}{l}\text { A licitação para o Sistema de Registro de Preços pode ser realizada } \\
\text { independentemente de dotação orçamentária, pois não há obrigatoriedade e dever de } \\
\text { contratar. }\end{array}$ \\
\hline $\begin{array}{l}\text { O preço registrado pode ser revisto em decorrência de eventual redução daqueles } \\
\text { praticados no mercado, ou que eleve o custo respectivo. }\end{array}$ \\
\hline strada a o \\
\hline
\end{tabular}

Fonte: Brasil, 2010.

O Sistema de Registro de Preços deve ser adotado preferencialmente quando (a) pelas características do bem ou serviço houver necessidade de contratações frequentes; (b) pela natureza do objeto não for possível definir previamente o quantitativo a ser demandado pela Administração; (c) for mais conveniente a aquisição de bens com previsão de entregas parceladas ou contratação de serviços necessários à Administração para o desempenho das atribuições; (d) e for vantajosa a aquisição de bens ou a contratação de serviços para atendimento a mais de um órgão da Administração Publica (BRASIL, 2010). 


\subsubsection{Pregão Eletrônico}

A Lei ํㅜ 10.520 de 17 de julho de 2002 criou o Pregão, a sexta modalidade da licitação (ver Quadro 4), podendo ser Presencial ou Eletrônico.

O Pregão Presencial foi regulamentado pelo Decreto $\mathrm{n}^{0} 3.555$, de 8 de agosto de 2000. O Decreto o 5.450 de 31 de maio de 2005, regulamenta o Pregão Eletrônico, autorizando Estados, Municípios e Distrito Federal a realizarem a licitação por meio da utilização de recursos de tecnologia da informação (BRASIL, 2002; BRASIL, 2005), com isto, oficialmente criou-se o e-Compras Governamental, o Sistema de Compras Eletrônico (TRIDAPALLI; FERRER, 2006).

Quadro 7 - Legislação Modalidade Pregão

\begin{tabular}{|c|c|}
\hline Legislação/Regulamentação & Ato \\
\hline Lei no 10.520 de 17 de julho de 2002 & Cria a Modalidade de Licitação Pregão \\
\hline Decreto $\mathrm{n}^{\circ} 3.555$, de 8 de agosto de 2000 ! & Regulamenta o Pregão Presencial \\
\hline Decreto $n^{0} 5.450$ de 31 de maio de 2005 & Regulamenta o Pregão Eletrônico \\
\hline
\end{tabular}

Fonte: Brasil, 2010; 2014b.

Pode-se definir o Pregão Eletrônico como a modalidade de licitação desenvolvida através de Sistema de Informação, com a utilização de aplicativos ou softwares (como por exemplo, o Comprasnet do Governo Federal), em ambiente virtual, com utilização da plataforma da web (internet), onde as Empresas licitantes estão presentes de forma virtual.

Em comparação com as outras modalidades de licitação, o Pregão trouxe consideráveis aperfeiçoamentos no sistema de compras da Administração Publica devido ter um modus operandi diferente das outras modalidades. No Quadro 8, temse uma descrição das fases do Pregão Presencial e Eletrônico. 
Quadro 8 - Fases do Pregão Presencial e Eletrônico

\begin{tabular}{|c|c|c|}
\hline Fase & Pregão Presencial & Pregão Eletrônico \\
\hline Autoria dos Lances & $\begin{array}{l}\text { Os presentes na sessão pública } \\
\text { sabem quem são os autores das } \\
\text { propostas. }\end{array}$ & $\begin{array}{l}\text { É vedada a indicação dos } \\
\text { licitantes responsáveis pelos } \\
\text { lances. }\end{array}$ \\
\hline Ordem dos Lances & $\begin{array}{l}\text { Os licitantes são classificados, de } \\
\text { forma sequencial e apresentam } \\
\text { lances verbais, a partir do autor } \\
\text { da proposta de maior preço e os } \\
\text { demais em ordem decrescente de } \\
\text { valor. }\end{array}$ & $\begin{array}{l}\text { Os licitantes podem oferecer } \\
\text { lances sucessivos independente } \\
\text { da ordem de classificação. }\end{array}$ \\
\hline $\begin{array}{l}\text { Termino da Fase de } \\
\text { Lances }\end{array}$ & $\begin{array}{l}\text { Ocorre quando não houver lances } \\
\text { menores que o último ofertado. }\end{array}$ & $\begin{array}{l}\text { Ocorre por decisão do pregoeiro } \\
\text { e o sistema eletrônico encaminha } \\
\text { aviso de fechamento iminente dos } \\
\text { lances. }\end{array}$ \\
\hline Habilitação & $\begin{array}{l}\text { A documentação deverá ser } \\
\text { apresentada em envelope } \\
\text { lacrado. }\end{array}$ & $\begin{array}{l}\text { Os documentos deverão ser } \\
\text { enviados via fax após a } \\
\text { solicitação do pregoeiro, ou de } \\
\text { acordo com o encerramento da } \\
\text { fase, conforme as cláusulas } \\
\text { previstas no Edital. }\end{array}$ \\
\hline Recurso & $\begin{array}{c}\text { A intenção do licitante de recorrer } \\
\text { deve ser feita de forma verbal, no } \\
\text { final da sessão com registro em } \\
\text { ata. }\end{array}$ & $\begin{array}{l}\text { A intenção de recorrer pode ser } \\
\text { realizada pelo licitante, de forma } \\
\text { imediata e motivada, em campo } \\
\text { próprio no sistema eletrônico. }\end{array}$ \\
\hline Adjudicação & $\begin{array}{c}\text { A falta de manifestação autoriza o } \\
\text { pregoeiro a adjudicar o item ao } \\
\text { vencedor do certame }\end{array}$ & $\begin{array}{c}\text { A falta de manifestação autoriza o } \\
\text { pregoeiro a adjudicar o item ao } \\
\text { vencedor do certame }\end{array}$ \\
\hline
\end{tabular}

Fonte: Brasil, 2014b.

Brasil (2014b) destaca que no Pregão, tanto o Presencial quanto o Eletrônico, há uma desburocratização do processo licitatório, pois a fase de habilitação vem depois da disputa de preços (lances), o que dá maior agilidade na execução do processo de compras. Na mesma direção, Othon e Araújo (2015) ressaltam a importância da inversão das fases no Pregão comparado às outras modalidades, bem como, um único momento de recursos administrativos.

Em síntese, pode-se afirmar que o Pregão Presencial trouxe significativos ganhos e melhorias na Licitação Pública, tais como (a) redução do lead time do processo de aquisição, (b) redução da burocracia e (c) redução do valor final dos itens licitados, entretanto, no Pregão Eletrônico há considerável diminuição em todos estes itens, além de (d) proporcionar maior transparência pública, (e) possibilitar maior nível de concorrência entre as Empresas licitantes, (f) redução do custo operacional e $(\mathrm{g})$ redução da probabilidade de combinação de preços por parte das Empresas licitantes. 
Possivelmente por estes motivos o Pregão Eletrônico tornou-se obrigatório na Administração Federal para contratação de bens e serviços comuns, sendo inclusive necessária a justificativa pelo dirigente ou autoridade competente, de forma motivada e circunstanciada quando da inviabilidade de realizar procedimento licitatório que não seja o Pregão Eletrônico (BRASIL, 2010; OTHON; ARAÚJO, 2015).

Esta obrigatoriedade do Pregão Eletrônico no Governo Federal pode ser traduzida em números que indicam o avanço desta modalidade bem como a economia trazida para a Administração Pública.

Gráfico 2 - Evolução do Valor das Compras Públicas (segundo tipo de processo)

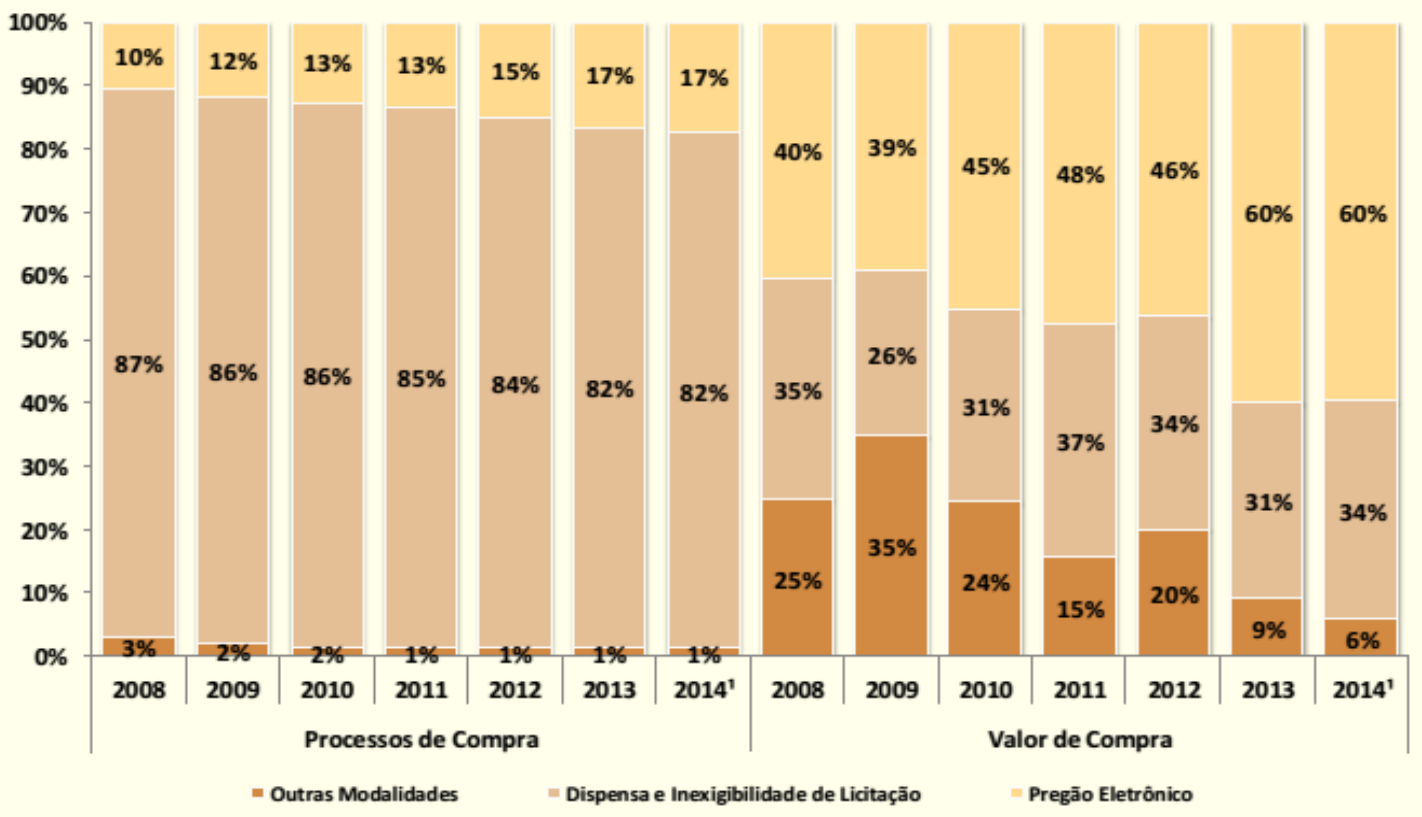

Fonte: Brasil, 2014d.

Os dados indicam um aumento no percentual da quantidade de processos de compras através da modalidade Pregão Eletrônico, saindo de 10\% em 2008 para 17\% em 2014 no Governo Federal. Não obstante o fato da quantidade de processos de compras com Dispensa de Licitação e Inexigibilidade de Licitação estarem na faixa de $80 \%$, o volume financeiro (valor da compra) empregado nas compras públicas através da modalidade Pregão Eletrônico chegou a 60\% em 2014. Brasil (2014d) salienta que quando se compara o Pregão Eletrônico apenas com as outras modalidades licitatórias, o mesmo correspondeu a $91,1 \%$ dos gastos com as aquisições na Administração Pública Federal. 
Concernente às economias provenientes do Pregão Eletrônico, o Gráfico 3 demonstra que ao longo dos anos de 2008 a $2014^{15}$ houve uma economia da ordem de $\mathrm{R} \$ 63,8$ bilhões para os cofres públicos do Governo Federal.

\section{Gráfico 3 - Evolução da Economia do Pregão Eletrônico nas Licitações Públicas}

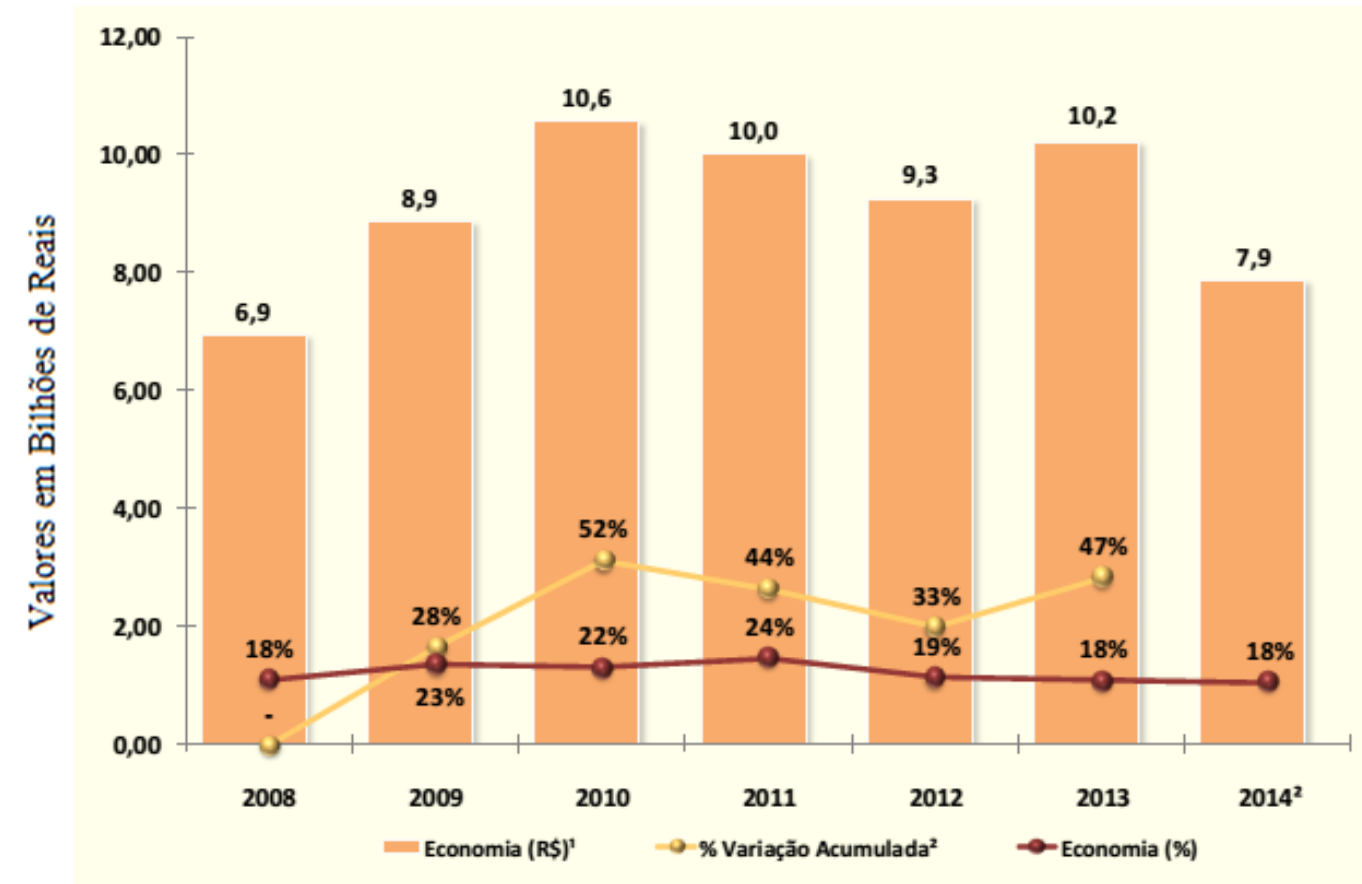

Fonte: Brasil, 2014d

Estes dados indicam que o Governo Federal vem anualmente ampliando a utilização do Pregão Eletrônico como método para as compras públicas, e consequentemente, vem diminuindo os custos através desta modalidade, gerando assim, economia para o erário público Federal.

Em relação aos Estados, dados indicam que os mesmos vêm sistematicamente adotando as boas práticas do Governo Federal na utilização do Pregão Eletrônico em suas licitações, mas, como afirma Dezolt et al. (2016), o Pregão Eletrônico não representa nem $50 \%$ do volume total de compras dos Estados, havendo muito espaço para o crescimento desta modalidade.

Dezolt et al. (2016) aponta que entre os Estados Brasileiros, 38\% estão investindo em pesquisa a fim de implementar o Pregão Eletrônico, como pode ser observado no Gráfico 4.

\footnotetext{
15 Os dados de 2015 não estão disponíveis no Portal do Ministério do Planejamento
} 


\section{Gráfico 4 - Estudos Visando Otimizar o Processo de Compras dos Estados}

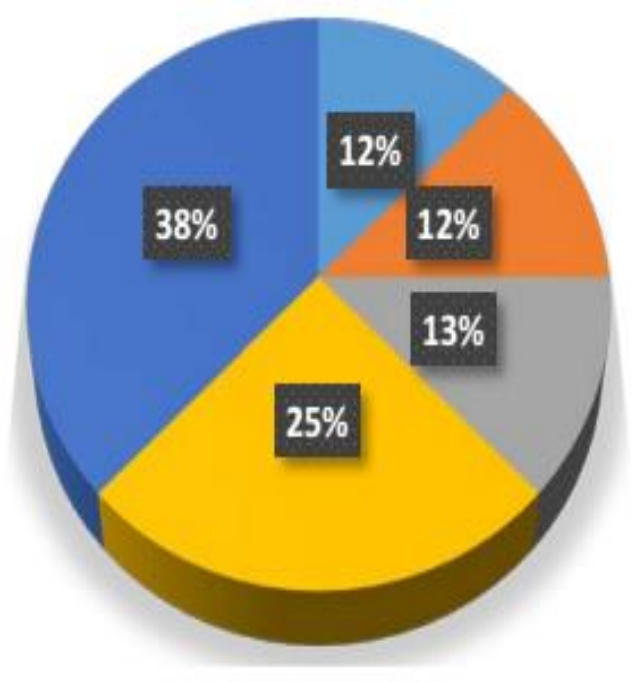

-Desenvolver processos de compras sustentáveis

- Elaborar estratégias de agregação de mais fornecedores por meio de campanhas de divulgação

• Elaborar procedimentos de aquisição de pequenos produtores (Cooperativas/Pudução Familiar)

- Fomentar a participação de micro e pequenas empresas nos pregões

- Implementar da modalidade de pregão eletrônico

Fonte: Dezolt et al., 2016.

O Gráfico 5, aponta algumas peculiaridades das licitações nos Estados. A Contratação Direta ainda movimenta um elevado número de processos, não obstante o baixo volume financeiro. O Pregão Eletrônico tem o maior volume financeiro empregado pelos Governos Estaduais, mas não representa a maior quantidade de processos de compras. A adesão a Ata de Registro de Preços (também chamada de "carona") de outras Instituições Públicas representa um importante papel na Gestão de Compras Governamentais, por isso representado no Gráfico 5 como o segundo maior valor financeiro desprendido pelos Governos Estaduais nas compras públicas.

\section{Gráfico 5 - Quantidade de Processos Licitatórios e Valores}

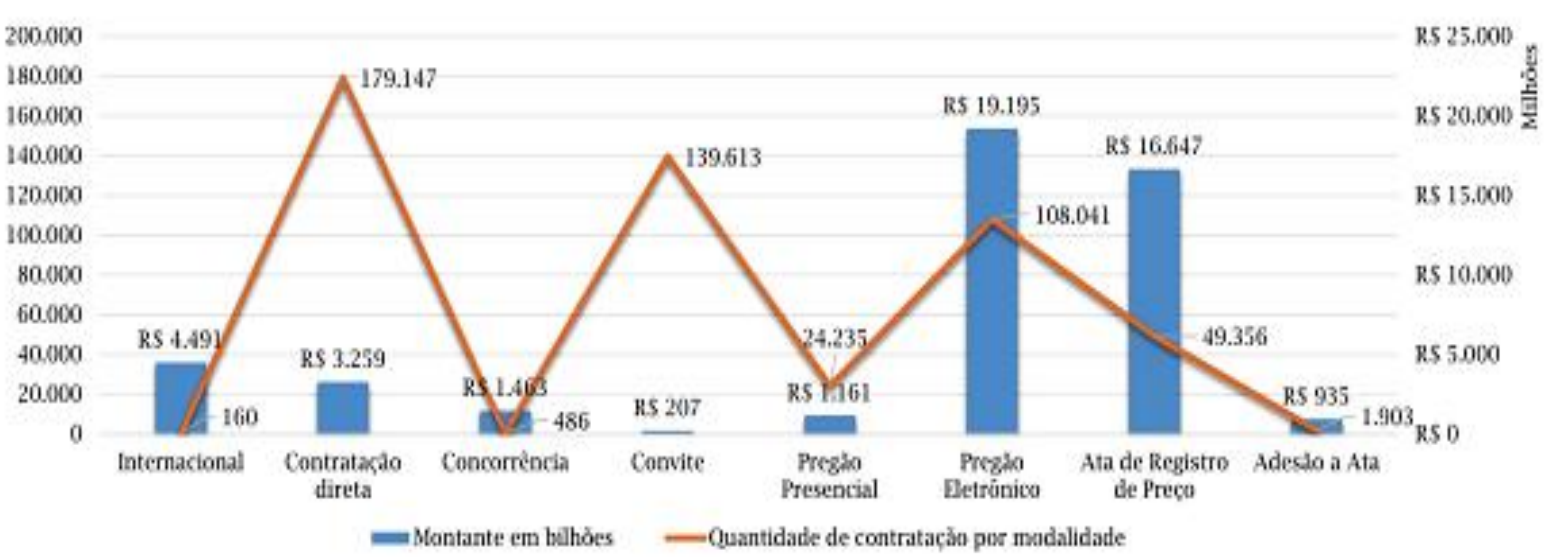

Fonte: Dezolt et al., 2016. 
Outro dado, segundo Dezolt et al. (2016), o Pregão Eletrônico apresenta o maior número de licitante médio por certame, sendo superior ao pregão presencial. Isto pode ser observado no Gráfico 6.

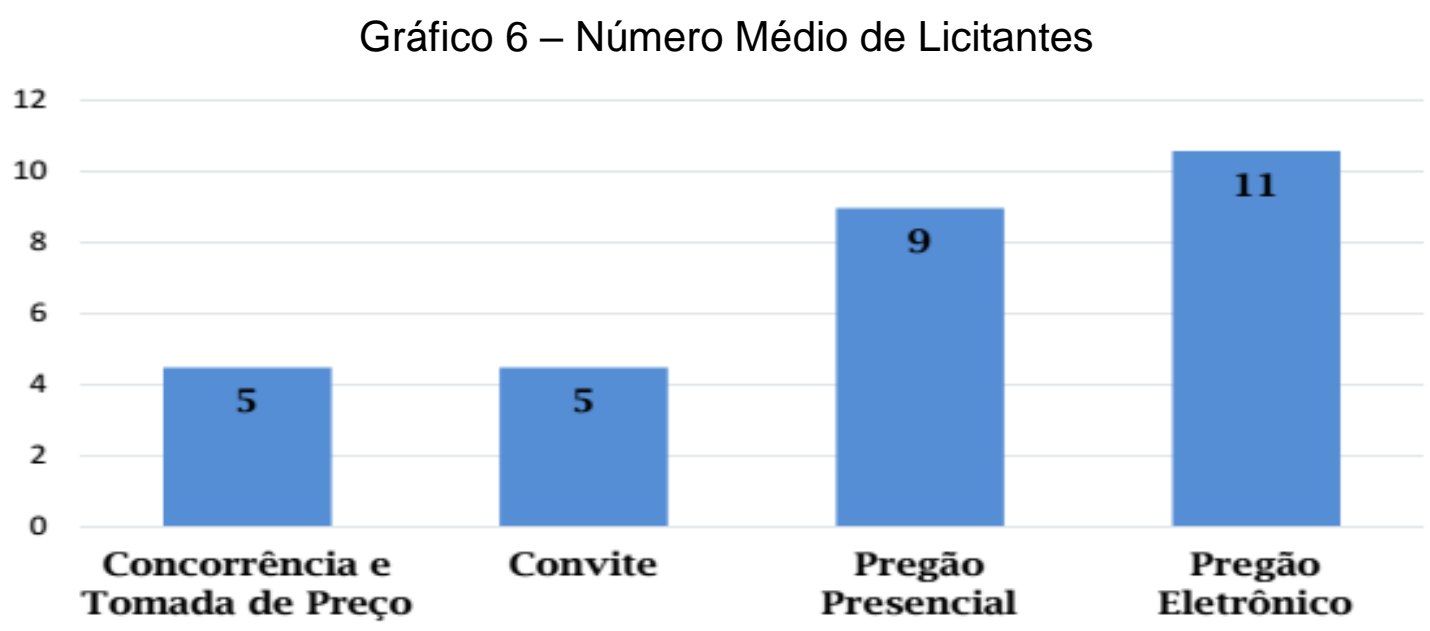

Fonte: Dezolt et al., 2016.

Quando se trata de compras públicas, em especial de medicamentos, produtos para a saúde ou objetos perecíveis, como alimentação, o fator tempo é um determinante. Logo, quanto menor o tempo de conclusão de um processo administrativo para aquisição, melhores serão os resultados. Neste tópico, Dezolt et al. (2016) traz uma importante informação sobre o Pregão Eletrônico nos Estados.

Excetuando as dispensas de licitação (abaixo de $R \$ 8.000,00$ ), o Pregão Eletrônico tem o menor lead time, com ciclo médio de 81 dias de duração, como pode ser observado no Gráfico 7.

\section{Gráfico 7 - Tempo Médio de Duração Processo de Aquisição}

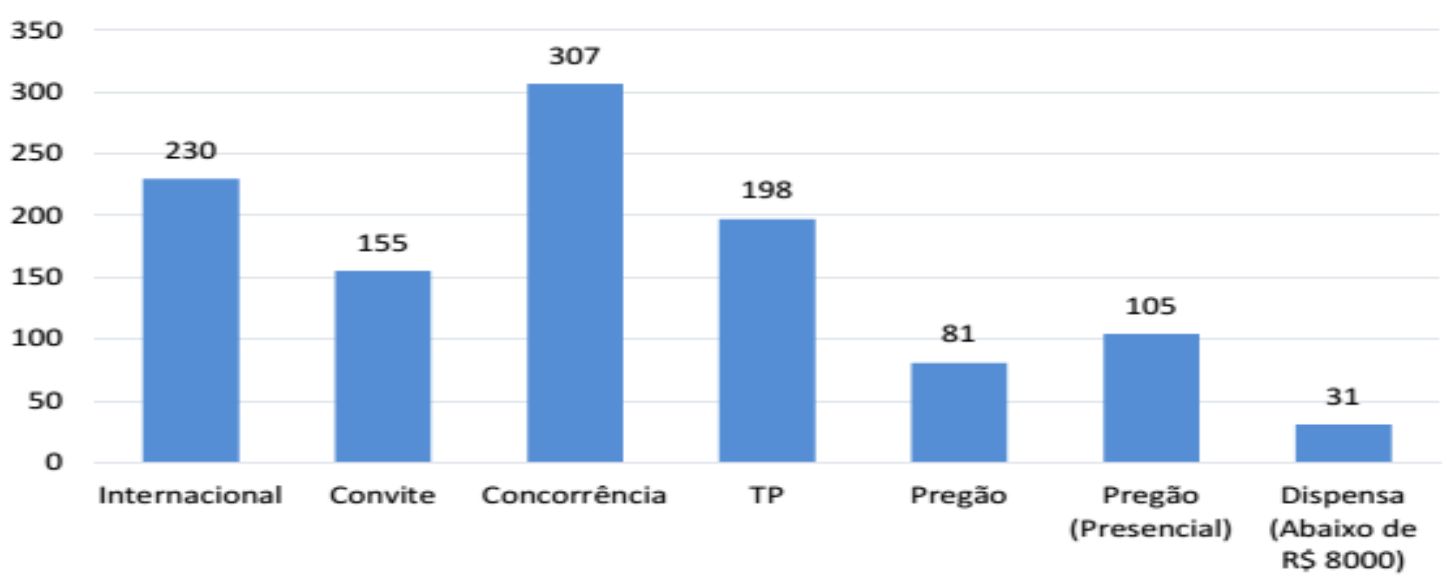

Fonte: Dezolt et al., 2016. 
Pode-se concluir que as licitações públicas através da modalidade Pregão têm trazido benefícios à Administração Pública, em especial, o Pregão Eletrônico tem contribuindo significativamente com a eficiência nos processos de compras públicas.

\subsubsection{Case do Governo do Estado do Amazonas}

Em pesquisa realizada no Sistema de Compras Eletrônicas no Governo do Estado do Amazonas, denominado de e-Compras, Tridapalli e Ferrer (2006) apresentam importantes considerações sobre a utilização do Pregão Eletrônico nas compras públicas e as vantagens econômicas para o Estado.

Segundo os autores, tanto o custo unitário por processo administrativo de compras quanto o valor final dos itens dos processos de aquisição, apresentaram redução.

Segundo Tridapalli e Ferrer (2006), esta redução no valor final dos itens, deve-se a dois fatores: credibilidade e pagamento. Credibilidade advinda da transparência promovida pelo Sistema de Compras Eletrônico. Pagamento devido ao cumprimento do prazo de pagamento aos Fornecedores, que por isto deixam de embutir o risco no seu preço. No caso do Governo do Estado do Amazonas, ao realizar um pedido de compras, a Unidade Administrativa deve fazer a reserva orçamentária, o que garante o pagamento dos Fornecedores num prazo de 30 dias. Com isto, houve uma redução de $20 \%$, em média, nos preços dos itens negociados no Pregão Eletrônico (TRIDAPALLI; FERRER, 2006).

Outro dado importante é o custo para a Empresa/Fornecedor que deseja participar do Pregão Eletrônico. O custo para uma Empresa participar de um processo licitatório tradicional versa em torno de $R \$ 234,91$. Já com o Pregão Eletrônico, este custo cai para $R \$ 50,70$, perfazendo uma economia de $78,42 \%$. Isso estimula e incentiva novas Empresas a participarem do processo licitatório, aumentando a concorrência e diminuindo $O$ valor final dos itens licitados (TRIDAPALLI; FERRER, 2006).

A partir deste estudo de caso, Tridapalli e Ferrer (2006) apresentam as principais vantagens proporcionadas pelo Sistema de Compras Eletrônico, conforme pode ser visto no Quadro 9. 
Quadro 9 - Vantagens do Sistema de Compras Eletrônico

\begin{tabular}{|c|}
\hline Proporciona Maior Transparência \\
\hline Redução dos Custos Operacionais \\
\hline Economia para o Governo \\
\hline Inclusão Digital para Pequenas e Médias Empresas \\
\hline Aperfeiçoamento do Controle Interno \\
\hline Oportunidade de Controle Externo \\
\hline Sistematização e Organização das Informações \\
\hline Acompanhamento das Tendências de Compras Eletrônicas
\end{tabular}

Fonte: Tridapalli e Ferrer, 2006.

\subsubsection{Gestão de Custos no Setor Público}

Por traz da temática em torno das compras públicas através do processo licitatório, em especial o Pregão Eletrônico, visando adquirir bens e serviços com menor valor, está a questão da Gestão de Custos. Quanto mais eficiente e eficaz é o processo de compras públicas, melhores serão os resultados financeiros, menores serão os desembolsos governamentais, maior será a economia para o erário público, isto é Gestão de Custos.

A Gestão de Custos é importante devido os recursos públicos estarem cada vez mais limitados, impossibilitando os Governos em atenderem todas as demandas e ainda gerir o funcionamento da máquina pública, por isso a necessidade dos governantes encontrarem uma forma inteligente de arrecadar e gastar o dinheiro público (TRIDAPALLI et al., 2011), principalmente através das compras públicas (DEZOLT et al., 2016).

No entendimento de Tridapalli e Borinelli (2015) todo este ciclo envolvendo as compras públicas, desde as definições das demandas até o final da vida útil dos ativos ou o fim de um contrato, pode ser definido como Gestão da Cadeia de Suprimentos.

A Gestão de Custos está na gênesis da Gestão da Cadeia de Suprimentos. Ballou (2006) é tácito ao afirmar que no passado o foco da logística era sobre a eficiência (produto certo, entregue no local certo, para a pessoa certa), hoje com o advento da globalização, terceirização da produção e exportação, a ênfase está na 
concepção e operação da Cadeia de Suprimentos, melhorando as receitas, diminuindo os custos e maximizando o lucro. No caso do Setor Público, o lucro advém com processos licitatórios mais vantajosos para a Administração, gerando assim economia (lucro) para os cofres públicos.

Guerreiro (2011) e Tridapalli et al., (2011) corroboram com Ballou (2006) sobre a importância da Gestão da Cadeia de Suprimentos na Gestão de Custos. De maneira especial, Tridapalli et al., (2011) e Tridapalli e Borinelli (2015) demonstram como a Gestão da Cadeia de Suprimentos aliada a Tecnologia da Informação trazem resultados extremamente satisfatórios para a Administração Pública, no que tange a Gestão de Custos, como exemplo tácito tem-se o Pregão Eletrônico.

Segundo a literatura especializada, custo é todo desembolso relacionado à produção de bens ou serviço. Padoveze (2011) define custos como valor pago por alguma coisa. Pinto (2009) entende que os custos são gastos acumulados relacionados à fabricação ou aquisição de produtos. Leone (2000) define custo como a medição monetária de bens ou serviços adquiridos. Os custos podem ser fixos ou variáveis, diretos ou indiretos, e geralmente estão atrelados ao tripé custo-volumelucro.

Em tempos de crise, desemprego, instabilidade econômica, globalização, alta competitividade, entrada de novos concorrentes, a Gestão de Custos passou a ser indispensável para sobrevivência, manutenção e lucratividade de qualquer Organização, tanto Pública como Privada.

No setor privado houve uma readequação da lucratividade a patamares mais baixos, o lucro passou a ser o resultado do preço do produto menos o custo (MARTINS et al., 2012), e o custo não pode mais ser repassado na sua íntegra para o consumidor final. No setor público, houve a necessidade de fazer cortes, realocar recurso, definir novas prioridades. No caso do Setor Público, o repasse do custo para o consumidor final representa aumento de tributos a fim de majorar a arrecadação.

Nesta mesma direção, os gastos públicos podem ser definidos como todo desembolso feito pela Administração Pública na aquisição de um bem ou contratação de um serviço (BRASIL, 2010; 2014b). Dado ao volume financeiro dos gastos públicos na União, Estados e Municípios.

Dados indicam que os gastos públicos com compras, aquisições e contratos têm crescido nos últimos anos. No Brasil, segundo Tridapalli e Borinelli (2015), as 
compras públicas representam $10 \%$ do Produto Interno Bruto (PIB). Em termos mundiais, as compras públicas compreendem 18\% do PIB Mundial (TRIDAPALLI et al., 2011).

Em 2005, União, Estados e Municípios gastaram $R \$ 114,2$ bilhões de reais (TRIDAPALLI, 2008). Em 2007 o Governo Federal gastou $R \$ 23,7$ bilhões de reais (TRIDAPALLI et al., 2011). Em 2014 os gastos com compras na União remontam a quantia de $\mathrm{R} \$ 62,1$ bilhões de reais (BRASIL, 2014b). No Estado do Amazonas, os gastos anuais nos últimos anos com compras públicas estão em torno de $R \$ 520$ milhões de reais, representando $30 \%$ do orçamento anual (TRIDAPALLI; BORINELLI, 2015). Ainda segundo Tridapalli e Borinelli (2015) este montante referese a compras de medicamentos, material de expediente, merenda escolar, material escolar, uniformes e permanentes.

Conclui-se de modo geral, que as compras públicas, perpassando pelo processo licitatório nas mais diversas modalidades, não podem ser encaradas apenas como um processo administrativo de aquisição, mas um importante elo dentro da Gestão da Cadeia de Suprimentos, que sendo gerida com eficiência trará resultados financeiros benéficos para a Administração Pública. Tridapalli et al. (2011) são tácitos ao afirmarem que todo esforço governamental para melhoria da qualidade dos gastos públicos deve passar indubitavelmente pela modernização da Gestão da Cadeia de Suprimentos. Ainda segundo os autores, a Gestão de Gastos Públicos no Brasil deve ser abordada em todas as fases da cadeia de suprimento de bens e serviços, com uso intenso do governo eletrônico, desde o levantamento das necessidades até a utilização final, com sistemas integrados (TRIDAPALLI et al., 2011).

\subsection{LEAN OFFICE}

O Sistema Toyota de Produção (STP) tornou-se sinônimo de padrão de qualidade no mundo Corporativo devido ao princípio do Lean Manufacturing (Manufatura Enxuta) também conhecido como Lean Thinking (Pensamento Enxuto) (SERAPHIM et al., 2010) que consiste na redução ou eliminação de desperdícios no processo produtivo, que não agregam valor para o cliente (TURATI; MUSETTI 2006; SERAPHIM et al., 2010; CARDOSO; ALVES, 2013), diminuindo os custos com a 
produção, aumentando o lucro das Empresas e ofertando produtos com alta qualidade e baixo custo ao cliente final (TURATI; MUSETTI 2006; CARDOSO; ALVES, 2013).

Segundo Elias et al. (2011) e Cardoso e Alves (2013), no início da década de 1950, num contexto pós-segunda guerra mundial de escassez de recursos, Eiji Toyoda e Taiichi Ohno adotaram uma nova forma de produção na fábrica da Toyota no Japão, denominado Sistema Toyota de Produção.

À época, o processo de industrialização havia rompido com o modelo de produção artesanal e desenvolvido o modelo de produção em massa. Àquele, um modelo altamente especializado, com alto custo, baixa produtividade e longo tempo para finalizar o produto, mas com grande variedade. Este, um modelo que não exige qualificação, baixo custo, alta produtividade e curto tempo para finalizar o produto, entretanto, sem muita variedade (CARDOSO; ALVES, 2013). Ainda segundo Elias et al. (2011) e Cardoso e Alves (2013), Eiji Toyoda e Taiichi Ohno perceberam que o modelo de produção em massa não funcionaria no Japão (por isso a necessidade de um novo modelo alternativo) nascendo assim o Sistema Toyota de Produção, que segundo Elias et al. (2011) combina as vantagens do modelo de produção artesanal e as vantagens do modelo de produção em massa.

Todavia o Sistema Toyota de Produção só ganhou notoriedade na década de 1980, conforme Seraphim et al. (2010), devido a um projeto de pesquisa do Massachusetts Institute of Technology (MIT), que estudou as práticas gerenciais adotadas por montadoras automotivas, constatando que os princípios adotados pela Toyota contribuíram para sua competitividade.

Em síntese, o Sistema Toyota de Produção, ou Lean Manufacturing, é um modelo de negócio que atua no processo produtivo, eliminando os desperdícios, objetivando a produção de produtos com alta qualidade e menor custo possível, a fim de alcançar a satisfação do cliente (CARDOSO; ALVES, 2013).

O Pensamento Enxuto (Lean Thinking), base do Sistema Toyota de Produção, segundo Womack e Jones (2003) é regido por cinco princípios que podem ser aplicados a qualquer processo produtivo para se chegar ao "estado enxuto". O estado enxuto, ainda segundo Womack e Jones (2003), consiste na eliminação de desperdícios (muda) nos processos produtivos, de tal forma que os produtos possam ser desenvolvidos com baixo custo de material, tempo e esforço humano. Estes princípios são: (1) Princípio do Valor, (2) Princípio do Fluxo do Valor, 
(3) Princípio do Fluxo, (4) Princípio do Sistema Puxado e (5) Princípio da Perfeição (WOMACK; JONES, 2003). Em síntese, o pensamento enxuto visa fazer cada vez mais com cada vez menos (PRATES; BANDEIRA, 2011).

Quadro 10 - Princípios do Pensamento Enxuto

\begin{tabular}{|c|l|}
\hline Princípios & \multicolumn{1}{c|}{ Descrição } \\
\hline Valor & $\begin{array}{l}\text { Consiste em identificar o que é valor para o cliente. O que gera e o } \\
\text { que não gera valor na perspectiva do cliente e não na perspectiva } \\
\text { das empresas, funções ou departamentos individuais. }\end{array}$ \\
\hline Fluxo do Valor & $\begin{array}{l}\text { Consiste em mapear o fluxo da produção e identificar os } \\
\text { desperdícios. Identificar todos os passos necessários para projetar, } \\
\text { pedir e fabricar o produto através do fluxo total de valores para } \\
\text { destacar as perdas, sem adição de valor, desde a matéria prima até } \\
\text { as mãos do consumidor final. }\end{array}$ \\
\hline Fluxo & $\begin{array}{l}\text { Consiste em implantar o fluxo contínuo. Realizar as açães que } \\
\text { geram fluxo de valor contínuo, sem interrupção, desvios, contra- } \\
\text { fluxos, esperas ou refugos. }\end{array}$ \\
\hline Produção Puxada & $\begin{array}{l}\text { Consiste em deixar o cliente puxar a produção. Fazer somente o que } \\
\text { for solicitado pelo cliente, reduzindo assim substancialmente a } \\
\text { quantidade de estoques da Organização. }\end{array}$ \\
\hline Perfeição & $\begin{array}{l}\text { Consiste em buscar a perfeição por meio da melhoria contínua. } \\
\text { Empenhar-se pela perfeiçâo removendo continuamente as } \\
\text { sucessivas camadas de perdas assim que elas forem descobertas. }\end{array}$ \\
\hline
\end{tabular}

Fonte: Adaptado de Womack e Jones, 2003.

Nesta mesma direção, Seraphim et al., (2010), Martins (2012) e Cardoso e Alves (2013) destacam que os princípios do Lean Thinking não se restringe apenas ao ambiente fabril, podendo também serem aplicados em ambientes administrativos. Corroborando com este pensamento, Tapping e Shuker (2010), destacam que com os impactos positivos do Sistema Toyota de Produção na Indústria de manufatura, os setores administrativos (produtores de informação e conhecimento) e os setores de serviços passaram a adotar os princípios do Pensamento Enxuto adequando-os à realidade do escritório.

A aplicação dos conceitos Lean em áreas administrativas, não manufatureiras, recebe o nome de Lean Office (SERAPHIM et al., 2010; TAPPING; SHUKER, 2010; CARSODO; ALVES, 2013). 
O Lean Office consiste na aplicação dos princípios do Lean Manufacturing ou Lean Thinking na gestão da Organização, posto que de $60 \%$ a $80 \%$ dos custos envolvidos na demanda de um cliente (seja uma peça ou serviço) é uma função administrativa (TAPPING; SHUKER, 2010). Corroborando, Seraphim et al. (2010) afirmam tacitamente que apenas $1 \%$ das informações geradas agregam valor de fato ao fluxo de valor do Escritório.

O Lean Office não é apenas um reducionismo do Lean Manufacturing com simples aplicação de técnicas administrativas e mudanças na redação do planejamento estratégico, com uma nova declaração de missão, visão e valores. 0 Lean Office é um novo paradigma na administração, uma nova forma de fazer gestão, rompendo com o modelo burocrático do escritório, eliminando os desperdícios e focando no cliente final.

Entretanto, a adequação dos princípios do Lean Manufacturing ao Escritório (Lean Office) não é tão simples assim, pois o Escritório, diferente da Indústria, produz informação/conhecimento/serviço, atividades intangíveis, não manufatureiras, de complexa mensuração, sendo difícil identificar os desperdícios e construir o fluxo de valor (TAPPING; SHUKER, 2010; SERAPHIM et al., 2010; MARTINS, 2012; CARDOSO; ALVES, 2013), agravando-se o fato pelo alto nível de dependência de funcionários e clientes nos processos administrativos, o que dificulta a padronização dos processos de trabalho e fluxo de valor da informação.

Tapping e Shuker (2010) propõem uma metodologia para implantar o Lean Office sistematizado em oito passos: (1) Comprometimento com o Lean; (2) Escolha do Fluxo de Valor; (3) Aprendizado sobre o Lean; (4) Mapeamento do Estado Atual; (5) Identificação de medidas de desempenho Lean; (6) Mapeamento do Estado Futuro; (7) Criação de planos Kaizen; e por último (8) Implementação dos planos Kaizen. No Quadro 11 segue uma síntese destes princípios: 
Quadro 11 - Princípios para Implantar o Lean Office

\begin{tabular}{|c|c|}
\hline Princípios & Descrição \\
\hline $\begin{array}{l}\text { Comprometimento } \\
\text { com o Lean }\end{array}$ & $\begin{array}{l}\text { É importante que todos, desde a alta Direção é o "chão de fábrica", } \\
\text { absolutamente todos os funcionários, devem apoiar o esforço de } \\
\text { transformação Lean para reduzir e eliminar o desperdício. }\end{array}$ \\
\hline $\begin{array}{l}\text { Escolha do Fluxo } \\
\text { de Valor }\end{array}$ & $\begin{array}{l}\text { Por valor entende-se por aquilo que está sendo criado que tem } \\
\text { alguma importância para um cliente que está disposto a pagar. E } \\
\text { fluxo refere-se a uma sequência de atividades necessárias para a } \\
\text { realização do serviço solicitado pelo cliente. É necessário escolher o } \\
\text { fluxo de valor a ser melhorado com base nas demandas dos clientes } \\
\text { e que esteja dentro dos limites da Organização. }\end{array}$ \\
\hline $\begin{array}{l}\text { Aprendizado } \\
\text { sobre o Lean }\end{array}$ & $\begin{array}{l}\text { É extremamente necessário que os todos da Organização aprendam } \\
\text { sobre os conceitos e ferramentas do Lean. Para tanto, é necessário } \\
\text { um Plano de Treinamentos, com palestras, cursos, workshop, e } \\
\text { principalmente a prática. Vale ressaltar que este passo varia de } \\
\text { Organização para Organização. }\end{array}$ \\
\hline $\begin{array}{l}\text { Mapear } \\
\text { Estad }\end{array}$ & $\begin{array}{l}\text { O mapeamento consiste numa representação visual, em papel, feito } \\
\text { à mãe ou com ajuda de um software, utilizando símbolos ou ícones, } \\
\text { do fluxo de material e informações de um fluxo de valor específico. } \\
\text { Para um bom mapeamento, deve-se observar e entender o fluxo de } \\
\text { valor. O recomendável é iniciar o mapeamento pelo ponto mais } \\
\text { próximo ao cliente e vir voltando aos processos ou atividades iniciais } \\
\text { do fluxo de valor. }\end{array}$ \\
\hline $\begin{array}{l}\text { Identificação de } \\
\text { medidas de } \\
\text { desempenho } \\
\text { Lean }\end{array}$ & $\begin{array}{l}\text { Para determinar uma métrica Lean que seja eficaz, deve-se procurar } \\
\text { aquela que permita a estratificação em componentes que abordem } \\
\text { os desperdícios identificados. Contudo, as métricas definidas devem } \\
\text { ser fáceis de entender e de coletar os dados. }\end{array}$ \\
\hline $\begin{array}{l}\text { Mape } \\
\text { Esta }\end{array}$ & $\begin{array}{l}\text { Também consiste numa representação visual, desenvolvido a partir } \\
\text { da análise crítica do mapa do estado atual, a fim de solucionar os } \\
\text { problemas detectados. Além disso, é necessário entender a } \\
\text { demanda do cliente, ou seja, suas solicitações. O mapa de valor } \\
\text { futuro é construído com ideias e sugestões de todos. }\end{array}$ \\
\hline $\begin{array}{l}\text { Criação dos } \\
\text { planos Kaizen }\end{array}$ & $\begin{array}{l}\text { O termo Kaizen significa melhorar um fluxo de valor ou de um } \\
\text { processo, com o intuito de aumentar o seu valor agregado } \\
\text { diminuindo os desperdícios. Em geral esta proposição de melhoria é } \\
\text { feita em etapas, daí a necessidade de um planejamento. }\end{array}$ \\
\hline $\begin{array}{c}\text { Implementação } \\
\text { dos planos Kaizen }\end{array}$ & $\begin{array}{l}\text { Esta etapa é para colocar o planejamento em prática. Existem três } \\
\text { passos para a implementação dos planos Kaizen: preparação, } \\
\text { implementação e follow-up. Para haver sucesso na transformação } \\
\text { Lean em uma Organização, as pessoas devem buscar sempre } \\
\text { formas para melhorar o fluxo de valor. }\end{array}$ \\
\hline
\end{tabular}

Fonte: Adaptado de Tapping e Shuker, 2010; Cardoso e Alves, 2013.

Cardoso e Alves (2013) empreenderam uma análise crítica por meio de estudo de casos múltiplos sobre a aplicabilidade dos passos propostos por Tapping e Shuker (2010) na implementação do Lean Office (Quadro 11) a fim de verificar sua eficácia, chegando à conclusão que estes passos são factíveis e eficazes, servindo como modelo às Empresas/Organizações que desejam implantar o Lean Office. 
Tanto o Lean Manufacturing quanto o Lean Office têm o objetivo de reduzir ou eliminar os desperdícios. Desperdício é tudo que não agrega valor ao cliente. Desperdícios de tempo, energia, recursos, mão de obra, etc. O Quadro 12 traça um paralelo entre categorias de desperdício no processo produtivo da Indústria e o desperdício no processo produtivo do Escritório:

Quadro 12 - Categorias de Desperdício Manufatura x Escritório

\begin{tabular}{|c|c|c|}
\hline Categoria & Indústria & Escritório \\
\hline $\begin{array}{l}\text { Processamento sem } \\
\text { valor }\end{array}$ & $\begin{array}{l}\text { Utilização errada de ferramentas, } \\
\text { procedimentos ou sistemas. }\end{array}$ & $\begin{array}{l}\text { Uso incorreto de procedimentos ou } \\
\text { sistemas inadequados, ao invés de } \\
\text { abordagens simples e eficazes. }\end{array}$ \\
\hline Superprodução & $\begin{array}{l}\text { Produzir excessivamente ou cedo } \\
\text { demais, resultando excesso de } \\
\text { inventário. }\end{array}$ & $\begin{array}{l}\text { Gerar mais informação, em meio } \\
\text { eletrônico ou papéis, além do que se } \\
\text { faz necessário, ou antes do } \\
\text { momento correto. }\end{array}$ \\
\hline Inventário & $\begin{array}{l}\text { Excesso de matéria-prima, de } \\
\text { peças em processamento e } \\
\text { estoque final. }\end{array}$ & $\begin{array}{l}\text { Alto volume de informação } \\
\text { armazenado (buffer sobrecarregado). }\end{array}$ \\
\hline Defeito & $\begin{array}{l}\text { Problema de qualidade do produto } \\
\text { ou serviço. }\end{array}$ & $\begin{array}{l}\text { Erros frequentes de documentação, } \\
\text { problemas na qualidade dos serviços } \\
\text { ou baixa performance de entrega. }\end{array}$ \\
\hline Transporte & $\begin{array}{l}\text { Movimento excessivo de pessoas } \\
\text { ou peças, resultando em dispêndio } \\
\text { desnecessário de capital, tempo e } \\
\text { energia. }\end{array}$ & $\begin{array}{l}\text { Utilização excessiva de sistemas } \\
\text { computacionais nas comunicações. }\end{array}$ \\
\hline Movimentação & $\begin{array}{l}\text { Desorganização do ambiente de } \\
\text { trabalho, resultando em baixa } \\
\text { performance dos aspectos } \\
\text { ergonômicos e perda frequente de } \\
\text { itens. }\end{array}$ & $\begin{array}{l}\text { Movimentação excessiva de pessoas } \\
\text { e informações. }\end{array}$ \\
\hline Espera & $\begin{array}{l}\text { Longos períodos de ociosidade de } \\
\text { pessoas e peças, decorrentes, por } \\
\text { exemplo, de máquina em } \\
\text { manutenção ou em preparação } \\
\text { (set-up), resultando em longo lead } \\
\text { time. }\end{array}$ & $\begin{array}{l}\text { Períodos de inatividade das pessoas } \\
\text { e informações (aprovação de } \\
\text { assinatura, aguardar fotocópias, } \\
\text { esperar no telefone). }\end{array}$ \\
\hline
\end{tabular}

Fonte: Seraphim et al., 2010.

Estes desperdícios também são chamados de "mudas" (PRATES; BANDEIRA 2011; ELIAS et al., 2011; MARTINS, 2012). As mudas são atividades desnecessárias, demandam recursos, energia, mão de obra, mas não agregam valor, aumentam os custos da produção/informação e diminuem a qualidade do produto final. 
Para identificar e eliminar as mudas o Lean Office aplica várias ferramentas. Seraphim et al.(2010) descreve algumas: (1) Cinco Esses (5S); (2) Fluxo Contínuo; (3) Trabalho Padrão; e principalmente o (4) Value Stream Mapping (VSM) ou Mapeamento do Fluxo de Valor (SERAPHIM et al., 2010; ELIAS et al., 2011).

\subsubsection{Mapeamento do Fluxo de Valor (VSM)}

O Value Stream Mapping (VSM) ou Mapeamento do Fluxo de Valor é uma ferramenta essencial para a produção enxuta (ELIAS et al., 2011) ou escritório enxuto (SERAPHIM et al., 2010) que auxilia na compreensão do fluxo de materiais e informações, visando à melhoria contínua da produção (ELIAS et al., 2011; LIBRELATO et al., 2014) e na eliminação de desperdícios ou mudas ${ }^{16}$ (SETH et al., 2008) através da criação de um mapa (TABANLI; ERTAY, 2013), que descreve o caminho que o material ou informação percorre no fluxo de valor, desde a matéria prima até as mãos do cliente (TYAGl et al., 2015), a partir do ponto de vista do cliente (SETH et al., 2008).

É uma plataforma visual, com uso de imagens, de todos os processos ou informações desde o input até o output, descrevendo cada tarefa, com seus ciclos de tempo e utilização (TYAGl et al., 2015), podendo ser apresentado/descrito em forma de mapa usando apenas lápis e papel (SETH et al., 2008; LIBRELATO et al., 2014), permitindo assim, o planejamento dos fluxos de processos e de informações dentro de uma Organização (SERAPHIM et al., 2010), como pode ser visto neste exemplo (Figura 5).

Na mesma direção, Elias et al. (2011) aponta que o Value Stream Mapping é uma ferramenta de comunicação, planejamento e gestão de mudanças, que aponta e orienta a Organização na tomada de decisões em relação ao fluxo de valor. Corroborando, Tabanli e Ertay (2013) definem o fluxo de valor como a coletânea de todas as ações aplicadas sobre um produto/serviço/informação, começando com a matéria prima e terminando no cliente final.

Em síntese, o Value Stream Mapping é uma ferramenta essencial, pois auxilia (1) na identificação do valor; (2) a visualizar o fluxo de produção (não apenas os processos individuais); (3) a identificar as fontes de desperdícios (mudas) no fluxo

\footnotetext{
${ }^{16}$ A identificação das mudas está relacionada às práticas do Lean Manufacturing no ambiente fabril e Lean Office no ambiente departamental.
} 
de valor; (4) no fornecimento de uma linguagem comum para tratar dos processos de manufatura; (5) nas decisões sobre os fluxos visíveis, de modo que se possa discuti-los; (6) na integração dos conceitos Lean Manufacturing; (7) na visualização das restrições do sistema (SETH et al., 2008; ELIAS et al., 2011; MARTINS, 2012; LIBRELATO et al., 2014; TYAGI et al., 2015).

Figura 5 - Exemplo de um VSM

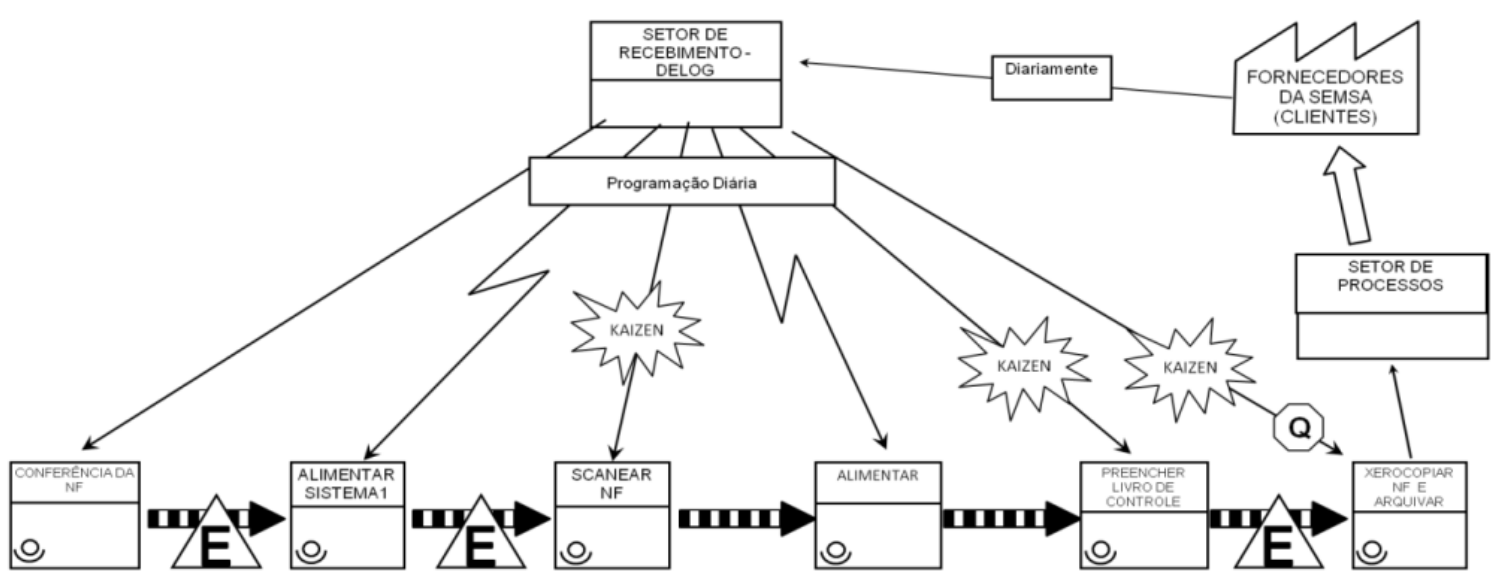

Fonte: Lima et. al., 2017.

Rother e Shook (2003) propuseram etapas para a construção do Value Stream Mapping que são amplamente empregadas na literatura (MAIA et al., 2010; ELIAS et al., 2011; LIBRELATO et al., 2014). Tyagi et al. (2015) também propuseram etapas para a construção do Value Stream Mapping. É bem similar ao modelo de Rother e Shook (2003) ${ }^{17}$, entretanto o modelo de Tyagi et al. (2015) é pouco citado na literatura e apresenta características de uma ampliação do modelos de Rother e Shook (2003).

Os passos para a construção do Value Stream Mapping segundo Rother e Shook (2003) são: (1) Escolha da Família de Produtos; (2) Desenho do Estado Atual e Futuro; (3) Plano de Trabalho e Implementação. Tyagi et. al. (2015) apresenta os seguintes passos: (1) Análise Inicial; (2) Mapa de Estado Atual; (3) Mapa de Estado Futuro; (4) Plano de Ação para alcançar o Estado Futuro e (5) Experimento. Abaixo segue quadro comparativo entre os dois métodos.

\footnotetext{
${ }^{17}$ Tyagi et al., (2015) não incluem em sua referencia bibliográfica Rother e Shook (2003).
} 
Quadro 13 - Quadro comparativo Rother e Shook (2003) x Tyagi et. al. (2015)

\begin{tabular}{|c|c|c|}
\hline Passos\Autores & Rother e Shook (2003) & Tyagi et. al. (2015) \\
\hline Passo 1 & Escolha da Família de Produtos & Análise Inicial \\
\hline Passo 2 & $\begin{array}{c}\text { Desenho do Estado Atual e } \\
\text { Futuro }\end{array}$ & Mapa de Estado Atual \\
\hline Passo 3 & $\begin{array}{c}\text { Plano de Trabalho e } \\
\text { Implementação }\end{array}$ & Mapa de Estado Futuro \\
\hline Passo 4 & -- & $\begin{array}{c}\text { Plano de Ação para alcançar o o } \\
\text { Estado Futuro }\end{array}$ \\
\hline Passo 5 & -- & Experimento \\
\hline Referências ${ }^{18}$ & 292 citações & 32 citações \\
\hline
\end{tabular}

Fonte: Elaborado pelo Autor, 2017.

Para efeitos didáticos esta pesquisa será feito uma junção entre os dois métodos, pois ambos se locupletam.

O primeiro passo para qualquer atividade de mapeamento é identificar uma família de produtos composta por um grupo de produtos que passam por etapas semelhantes de processamento. A Organização precisará escolher uma família de produtos de acordo com os critérios preestabelecidos, no sentido de mapear o fluxo em questão. Este critério pode ser o indicador de desperdícios na manufatura dessa família de produtos (MAIA, et al., 2010; ELIAS, et al., 2011; LIBRELATO et al., 2014).

Corroborando, Tyagi et. al. (2015) afirma que a análise inicial consiste em fazer um levantamento, estudo ou pesquisa dentro da Organização a fim de descobrir qual processo ou processos não estão agregando valor no fluxo de valor na perspectiva do cliente. A questão norteadora deve ser: Qual o problema atual com o fluxo de valor para este produto do ponto de vista do cliente e do ponto de vista da Organização? Por exemplo, os clientes podem estar exigindo uma redução de preço para um determinado produto ou serviço. Por outro lado a Organização pode estar produzindo um produto que tem uma margem inaceitável para o negócio, ou um produto com problema de qualidade.

\footnotetext{
${ }^{18}$ Em pesquisa realizada no Google Acadêmicos utilizando o título do Livro/Artigo de Rother e Shook (2003) e Tyagi et. al. (2015) . Disponível em: < https://scholar.google.com.br >. Acesso em: 12.out.2016.
} 
O próximo passo é desenhar o Mapa do Estado Atual do produto ou processo (ou família de produtos) selecionado anteriormente e seguir a trilha ou caminho deste dentro da Organização. É desenhado um mapa do estado atual do fluxo do processo/produto, "porta-a-porta" do cliente final ao fornecedor, bem como seus fluxos de materiais e de informação. (ELIAS, et al., 2011).

No desenho do mapa, deve-se indicar no canto superior direito os clientes e no esquerdo os fornecedores. O fluxo de materiais é desenhado na parte inferior da esquerda para a direita, enquanto o de informações desenhado na parte superior da direita para a esquerda. Caso o fluxo de material possua uma complexa rede de ramificações, sugere-se indicar apenas as dos principais elementos, e os demais depois caso necessário.

Prates e Bandeira (2011) destacam que para cada processo ou produto mapeado, será necessário mensurar alguns dados:

- Tempo de Ciclo (TC) - é o tempo máximo permitido em cada estação de trabalho para a realização das tarefas, antes do deslocamento do trabalho para a estação seguinte. Também estabelece a velocidade de produção de uma linha;

- Tempo Takt (Takt Time) - é o tempo de produção disponível dividido pelo índice de demanda do cliente. Por exemplo, se um cliente demanda 300 peças por dia e a fábrica opera 600 minutos por dia, o tempo takt será de 2 minutos. O takt time define o ritmo de produção conforme o índice de demanda do cliente.

- Lead Time - é o tempo que leva para entregar um produto ou serviço a partir do start inicial efetuado pelo cliente até a entrega deste produto/serviço ao cliente. Quanto menor o lead time mais rápido o produto chegará às mãos do cliente, o que implica em redução de estoques intermediários bem como na redução de custos.

Nesta etapa é proposto o Mapa do Estado Futuro, desenvolvido a partir do Mapa do Estado Atual, levando em conta os princípios do pensamento enxuto. O objetivo de mapear o estado futuro é apontar os desperdícios (mudas) e eliminá-los através da implementação de um fluxo de valor em um "estado futuro" que pode tornar-se uma realidade em um curto período de tempo (ELIAS et al., 2011). Nesta 
mesma direção Rother e Shook (2003) apontam alguns princípios que devem ser avalizados na construção do Mapa Futuro:

- Produzir conforme o takt time;

- Desenvolver um fluxo contínuo;

- Enviar a programação do cliente para apenas um processo de produção;

- Nivelar o mix de produção;

- Nivelar o volume de produção;

- Aplicar o kaizen nas fontes de desperdícios.

Librelato et al. (2014) apresenta um quadro destacando exemplos da aplicabilidade do Value Stream Mapping em várias áreas de gestão, conforme pode ser observado no Quadro 14.

Quadro 14 - Aplicabilidade do Value Stream Mapping

\begin{tabular}{|c|}
\hline Melhoria contínua do sistema de produção de Fábricas. \\
\hline Melhoria na Gestão da Cadeia de Suprimentos (SCM). \\
\hline Geração de valor ao processo de vendas. \\
\hline $\begin{array}{l}\text { Associado a conceitos Lean Office agrega valor aos processos } \\
\text { administrativos. }\end{array}$ \\
\hline Análise e melhoria dos processos de serviços. \\
\hline $\begin{array}{l}\text { Eliminação de perdas nos processos associados a situações } \\
\text { de emergência na área da saúde. }\end{array}$ \\
\hline $\begin{array}{l}\text { Melhoria nas operações de serviços e processos na } \\
\text { administração pública. }\end{array}$ \\
\hline
\end{tabular}

Fonte: Adaptado de Librelato et al., 2014.

A aplicação do Value Stream Mapping à Gestão da Cadeia de Suprimentos agrega vantagem competitiva à cadeia, identificando as atividades ou processos de trabalho que não agregam valor à cadeia, eliminando os desperdícios (mudas). Seth et al. (2008) afirmam que o VSM tem sido amplamente utilizado para avaliar o desperdício intra e entre Empresas. Tal perspectiva está alinhada com a Teoria das Restrições (Librelato et al., 2014). 


\subsection{TEORIA DAS RESTRIÇÕES (TOC)}

A Theory of Constraints (TOC) ou Teoria das Restrições, segundo Alves et al. (2011) é um método de gestão centrado na constante melhoria dos processos que restringem o fluxo da produção, objetivando melhorar continuamente o desempenho das operações de fabricação. A teoria das restrições busca otimizar a produção, identificando as restrições do sistema, eliminando ou minimizando estas restrições, a fim de melhorar o desempenho da Organização.

Restrição pode ser definida como qualquer fator ou elemento que impeça o sistema de atingir seu maior nível de desempenho em relação a sua meta (SIMATUPANG et al., 2004; WATSON et al., 2007; PERGHER et al.; 2011; ALVES et al., 2011). Em síntese, o objetivo da TOC é identificar as restrições e gerencia-las com eficácia (PERGHER et al., 2011).

Simatupang et al. (2004), Pergher et al. (2011), Alves et al. (2011), Votto e Fernandes (2014), Santos e Alves (2015) descrevem as cinco etapas para implementação da TOC: (1) Identificar a restrição do sistema; (2) Explorar ao máximo a restrição do sistema; (3) Subordinar todo o sistema à exploração da restrição; (4) Elevar a restrição do sistema; (5) Voltar ao primeiro passo (assim que a restrição for quebrada), a fim de evitar que a inércia se torne uma nova restrição, conforme Figura 6.

Figura 6 - Etapas da Teoria das Restrições

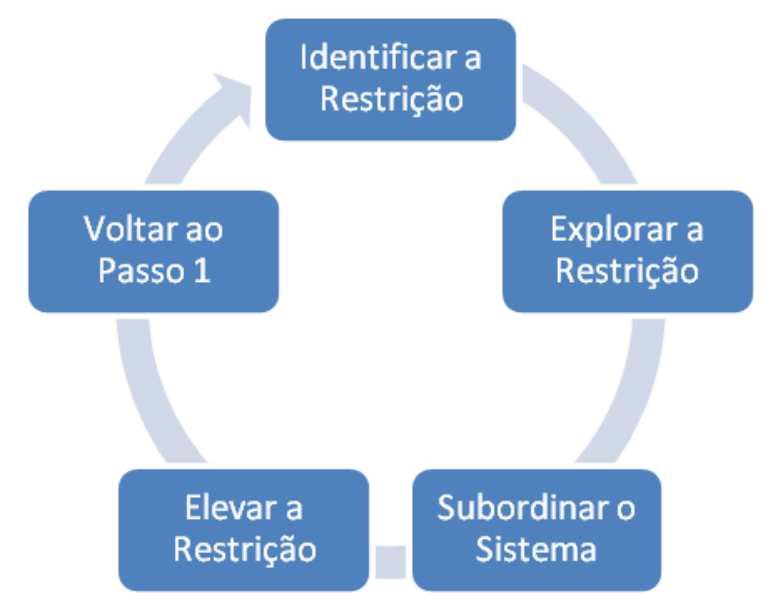

Fonte: Elaborado pelo autor, 2017. 
O primeiro passo consiste em identificar a restrição do sistema. Pode-se utilizar o Value Stream Mapping (LIBRELATO et al., 2014) como ferramenta para descobrir as restrições dos processos de trabalho ou observação empírica de estoque em processo (work in process) no decorrer da produção. Simatupang et al. (2004) afirmam que estas restrições quando relacionadas a cadeia de suprimentos podem ser física ou não física, interna ou externa.

O segundo passo consiste em elevar o nível da restrição a fim de que produza mais. É preciso encontrar uma forma de explorar a restrição a fim de conseguir atingir uma melhora no seu rendimento, aumentando a produtividade. Lembrando que a saída (output) do sistema está limitada à transferência da restrição (ALVES et al., 2011). Em relação à SCM, os membros da cadeia precisam garantir que a restrição identificada na cadeia esteja trabalhando em os produtos certos para maximizar os lucros. Por exemplo, se a disponibilidade do produto é a restrição, o fornecedor tem de observar a restrição e continuamente reabastecer a restrição sem atrasos (SIMATUPANG et al., 2004).

Terceiro, subordinar todo o sistema à exploração da restrição, evitando assim estoque em processo (work in process). Os demais recursos devem trabalhar no ritmo da restrição. É a restrição que "dita" a velocidade do sistema. Se os recursos não restritivos trabalharem mais rápido que a restrição, aumentará o nível de estoque em processo (ALVES et al., 2011).

No quarto passo, deve-se aumentar a produção da restrição do sistema, podendo (a) adquirir uma nova máquina, (b) terceirizar o processo de trabalho ou (c) enviar para outras fábricas o que passaria pela restrição. Simatupang et al. (2004) citam por exemplo, que um fornecedor, membro da cadeia, pode elevar a capacidade da restrição fornecendo respostas rápidas às necessidades dos clientes.

Por último, se a restrição foi quebrada deve-se começar todos os passos novamente, renovando o ciclo de melhoria para elevar a inércia do sistema (PERGHER et al., 2011; ALVES et al., 2011).

A Teoria das Restrições é uma filosofia gerencial que resulta em resultados positivos como aumento do lucro, redução dos níveis de inventário e de despesa operacional, melhorando assim o desempenho da organização (PACHECO, 2014).

Aplicada à Gestão da Cadeia de Suprimentos, a TOC trará resultados significativos na gestão de processos e componentes de gestão, eliminando ou melhorando as restrições da cadeia. 


\section{PROCEDIMENTOS METODOLÓGICOS}

Zanella (2009) afirma que o conhecimento científico é adquirido por meio de procedimentos metodológicos que investigam um objeto de forma organizada, seguindo normas e técnicas, por meio da aplicação de um método.

Método é o caminho sistemático e organizado que será percorrido para se chegar ao fim da pesquisa científica. É o caminho que o pesquisador estabelece para ampliar o conhecimento sobre algum objeto, fato ou fenômeno (SEVERINO, 2007; ZANELLA, 2009). No entendimento de Santos (2005), o método é importante pois economiza tempo e recursos, além de dar segurança na ação para se chegar ao resultado da pesquisa.

A pesquisa científica tem por objetivo a produção de um novo conhecimento, respondendo a problemas e indagações teóricas e práticas (ZANELLA, 2009). Para Gil (2010), a pesquisa é desenvolvida mediante afluência dos conhecimentos disponíveis mais a utilização cuidadosa de métodos e técnicas de investigação científica.

Entretanto, conforme Zanella (2009) e Prodanov e Freitas (2013) é grande o panteão de tipologias e taxionomias no campo das técnicas e procedimentos metodológicos usados para descrever as pesquisas científicas. Minayo (1996) apud Zanella (2009) afirma que cada autor tem peculiaridades na sua forma teórica de entendimento e análise da realidade. Por isso a importância, segundo Gil (2010), de estabelecer os métodos que servirão de pressuposto metodológico na realização da pesquisa.

Para esta pesquisa, cujo objetivo geral visa propor um modelo de otimização do Processo de aquisição de medicamentos na rede municipal de saúde de Manaus, foi utilizado como método o estudo de caso (YIN, 2010).

Constituiu-se de uma pesquisa exploratória, de natureza aplicada, cuja abordagem do problema foi utilizada o procedimento epistemológico da pesquisa quantitativa e qualitativa. 
Figura 7 - Metodologia

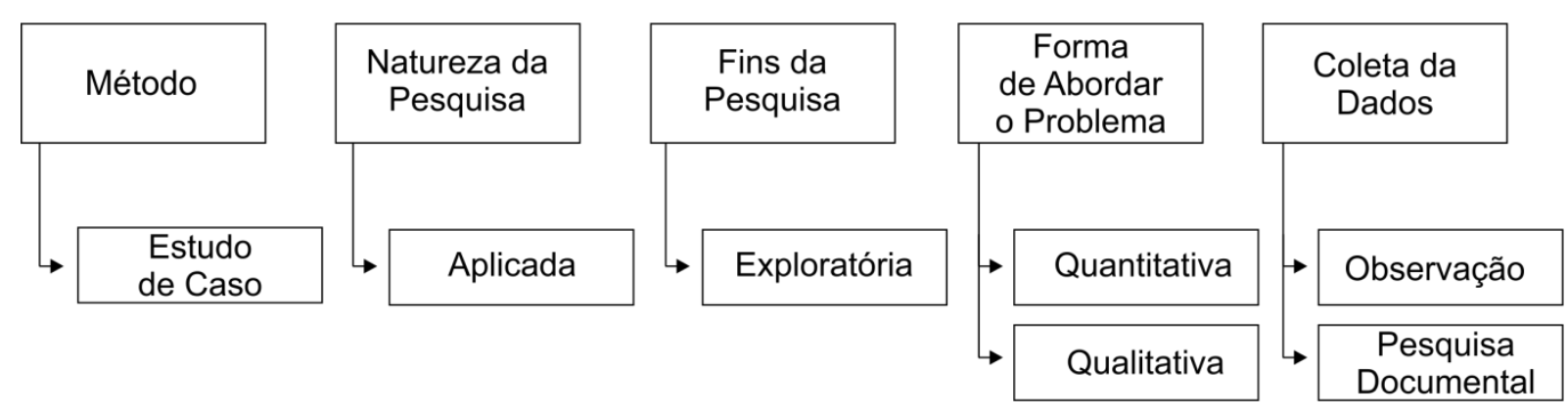

Fonte: Elaborado pelo autor, 2017.

A pesquisa aplicada está relacionada à aquisição de conhecimentos com objetivo de aplicação prática numa situação específica (GIL, 2010; PRODANOV; FREITAS, 2013). Sua motivação é a solução de problemas concretos, práticos e operacionais (ZANELLA, 2009). Neste sentido, a pesquisa aplicada se coaduna com o objetivo geral desta pesquisa, na busca ativa de responder ao problema da pesquisa: quais as principais restrições que afetam o processo de aquisição de medicamentos na rede municipal de saúde de Manaus?

A pesquisa exploratória tem o objetivo de aprofundar o conhecimento sobre um fato, fenômeno ou objeto, proporcionando maior familiaridade com o problema, tornando-o mais explícito (ZANELLA, 2009; GERHARDT; SILVEIRA, 2009; GIL, 2010).

Gil (2010) afirma que a grande maioria das pesquisas acadêmicas, num primeiro momento, assumem o caráter de pesquisa exploratória, pois no início da pesquisa ainda não se tem informações detalhadas e claras sobre o objeto de estudo. Ainda, segundo o autor, na pesquisa exploratória o levantamento de dados pode ocorrer de diversas formas, como por exemplo, a pesquisa bibliográfica, pesquisa de campo ou estudo de caso (GIL, 2010).

Segundo Zanella (2009) a pesquisa quantitativa se caracteriza pela utilização de instrumentos estatísticos na coleta e tratamento dos dados. Preocupase com a representatividade numérica, com a medicação objetiva e a quantificação dos resultados. Gerhardt e Silveira (2009) e Prodanov e Freitas (2013) destacam que na pesquisa quantitativa tudo pode ser quantificável, opiniões e informações podem ser traduzidas em números. 
A pesquisa qualitativa caracteriza-se pela não utilização de instrumentos estatísticos na análise dos dados (ZANELLA, 2009; PRODANOV; FREITAS, 2013). Segundo Gerhardt e Silveira (2009) a pesquisa qualitativa se preocupa com aspectos da realidade que não podem ser quantificados, na mesma direção Prodanov e Freitas (2013) descrevem a pesquisa qualitativa como um vínculo inseparável entre o mundo objetivo e a subjetividade do sujeito, que não pode ser medida, mensurada ou descrita numericamente.

$\mathrm{Na}$ pesquisa qualitativa, o pesquisador exercer papel preponderante. Gerhardt e Silveira (2009) destacam que o pesquisador é, concomitantemente, sujeito e objeto de sua pesquisa, por isso, os pesquisadores tendem a analisar os dados indutivamente (PRODANOV; FREITAS, 2013). É justamente nesta questão que Gerhardt e Silveira (2009) frisam que o pesquisador deve atentar para os limites e riscos da pesquisa qualitativa:

- Excessiva confiança;

- Risco que as notas possam representar uma tentativa da totalidade do objeto estudado;

- Falta de detalhes sobre os processos através dos quais as conclusões foram alcançadas;

- Falta de observância de aspectos diferentes sob enfoques diferentes;

- Certeza com relação a seus dados;

- Sensação de dominar seu objeto de estudo;

- Envolvimento do pesquisador na situação pesquisada.

$\mathrm{Na}$ abordagem do problema, nesta Pesquisa, foi utilizado o procedimento epistemológico da pesquisa quantitativa e qualitativa. No entendimento de Zanella (2009) as pesquisas qualitativa e quantitativa são complementares e podem ser utilizadas em uma mesma pesquisa. Na mesma direção, Prodanov e Freitas (2013) destacam que essas duas abordagens estão interligadas e complementam-se.

O método empregado foi o estudo de caso. O lócus da pesquisa foi o Departamento de Logística da Secretaria Municipal de Saúde de Manaus (SEMSA). 


\subsection{MÉTODO DA PESQUISA: ESTUDO DE CASO}

Turrioni e Mello (2012) apresentam sinteticamente o desenvolvimento histórico do Estudo de Caso no campo da pesquisa científica. Segundo os autores, o estudo de caso é uma das mais antigas ferramentas de pesquisa, sendo aplicada desde o início do séc. XX na Medicina e posteriormente na Antropologia e Sociologia, onde foi aprimorado. Nas décadas de 30 e 40 entrou em decadência devido à metodologia positivista com foco nas pesquisas quantitativas. O estudo de caso ressurge na década de 50, não como método de pesquisa, mas como técnica de ensino na Harvard Business School, sendo apenas na década de 60 seu retorno como ferramenta metodológica para pesquisas científicas.

O estudo de caso é uma investigação apurada (MORESI, 2003), uma pesquisa que analisa com profundidade um ou mais objetos de pesquisa (SANTOS, 2005; ZANELLA, 2009), podendo ser uma Organização, grupos de uma Organização (MORESI, 2003; GERHARDT; SILVEIRA, 2009), um Programa de Governo, um Sistema Educativo, uma Unidade Social (GERHARDT; SILVEIRA, 2009), uma pessoa (GERHARDT; SILVEIRA, 2009; PRODANOV; FREITAS, 2013), uma família, grupo ou comunidade (PRODANOV; FREITAS, 2013).

O objetivo do estudo de caso é fornecer uma análise do contexto e dos processos envolvidos no fenômeno estudado (MORESI, 2003) possibilitando um grande conhecimento com riqueza de detalhes (SANTOS, 2005) além de conhecer profundamente o "como" e o "porquê" de uma determinada situação que se supõe ser única, procurando descobrir o que há nela de mais essencial e característico (GERHARDT; SILVEIRA, 2009).

Yin (2010) apresenta uma definição técnica do método. Para, o autor, o estudo de caso é uma inquirição empírica que investiga um fenômeno hodierno em profundidade e em seu contexto de vida real, sobretudo quando os limites entre 0 fenômeno e o contexto não são notadamente evidentes.

Portanto, o estudo de caso foi o método de pesquisa que pode trazer luz e conhecimento sob a questão-problema norteadora deste Projeto: quais as principais restrições que afetam o processo de aquisição e distribuição de medicamentos na rede municipal de saúde? 


\subsection{LÓCUS DA PESQUISA: DEPARTAMENTO DE LOGÍSTICA - DELOG}

Dentro da estrutura administrativa preconizada pelo Regimento Interno da Secretaria Municipal de Saúde de Manas ${ }^{19}$, o Departamento de Logística está vinculado a Subsecretaria de Gestão Administrativa e Planejamento, que compõe os Órgãos de Apoio à Gestão. A estrutura organizacional do DELOG pode ser visualizada na Figura 8.

Figura 8 - Estrutura Administrativa do DELOG ${ }^{20}$

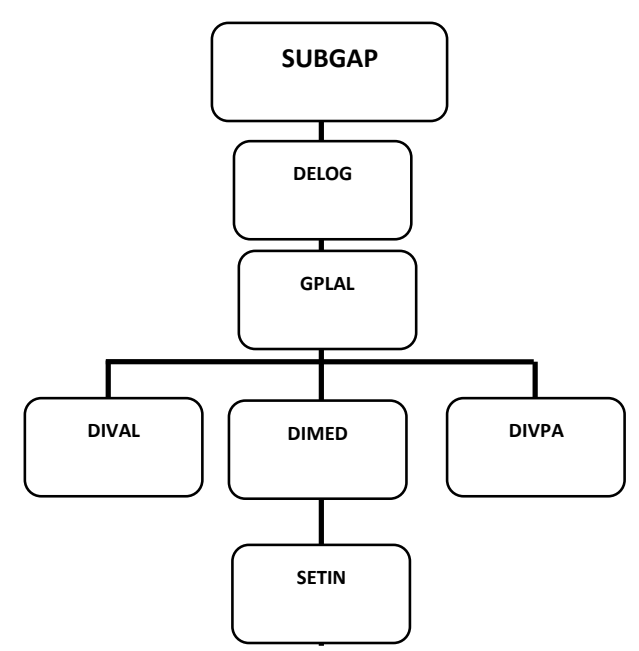

Fonte: Gerência de Planejamento em Logística/DELOG.

O Departamento de Logística é o setor competente para gerenciar a cadeia de suprimentos dentro da estrutura administrativa da SEMSA. Três eixos macros de produtos/materiais estão sob a responsabilidade do DELOG: (1) Medicamentos e Insumos para a Saúde; (2) Patrimônio; (3) Insumos em Geral. No Quadro 15 têm-se uma visualização macro destes eixos.

\footnotetext{
${ }^{19}$ Decreto no 2.681, de 26 de dezembro de 2013. Publicado no Diário Oficial do Município no 3.319 de 26 de dezembro de 2013.

${ }^{20}$ Legenda: SUBGAP - Subsecretaria de Gestão Administrativa e Planejamento; DELOG - Departamento de Logística; GPLAL - Gerencia de Planejamento e Logística; DIVAL - Divisão de Almoxarifado; DIMED - Divisão de Medicamentos; DIVPA - Divisão de Patrimônio; SETIN - Setor de Insumos
} 
Quadro 15 - Eixos Macros

\begin{tabular}{|c|c|}
\hline Eixos & Produtos/Materiais \\
\hline $\begin{array}{c}\text { Medicamentos e Insumos } \\
\text { para a Saúde }\end{array}$ & $\begin{array}{ll}\text { - } & \text { Medicamentos } \\
\text { - } & \text { Insumos de odontogia } \\
\text { - } & \text { Insumos de saúde } \\
\text { - } & \text { Insumos de laboratório }\end{array}$ \\
\hline Patrimônio & 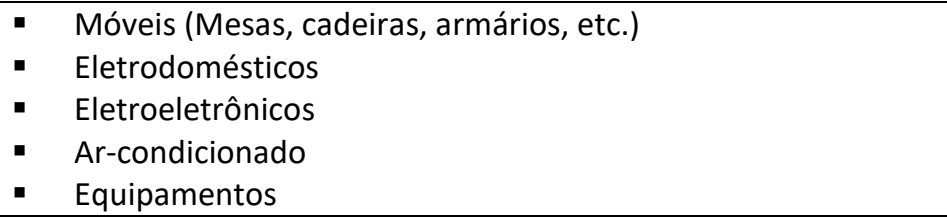 \\
\hline Insumos em Geral & $\begin{array}{l}\text { - } \quad \text { Artigos de papelaria (caneta, lápis, papel A4, etc.) } \\
\text { - } \quad \text { Descartáveis (copos, sacos, etc.) } \\
\text { - } \quad \text { Material de limpeza } \\
\text { - } \quad \text { Suprimentos de informática (tonner, cartucho de impressora, } \\
\text { - } \quad \text { etc.) } \\
\text { Equipamento de Proteção Individual - EPI }\end{array}$ \\
\hline
\end{tabular}

Fonte: Gerência de Planejamento em Logística/DELOG.

Compete ao DELOG: adquirir (logística de suprimentos), armazenar (logística interna), distribuir (logística de distribuição) e recolher (logística reversa) todos os produtos/materiais que compõem este três eixos macros.

No Quadro 16 os processos de trabalho, desde o input até o output podem ser visualizados detalhadamente.

\section{Quadro 16 - Cadeia de Suprimento de Medicamentos}

\section{PROCESSAMENTO}

\begin{tabular}{|c|c|c|c|}
\hline & Logística de Suprimentos & Logística Interna & Logística de Distribuição \\
\hline & $\begin{array}{l}\text { - Aquisição de } \\
\text { Medicamentos e Insumos } \\
\text { para Saúde } \\
\text { - Aquisição de Patrimônio } \\
\text { - Aquisição de Insumos em } \\
\text { Geral }\end{array}$ & $\begin{array}{l}\text { Receber os } \\
\text { produtos/materiais } \\
\text { conforme Nota de } \\
\text { Empenho; } \\
\text { Armazenar } \\
\text { corretamente, } \\
\text { conforme lote, } \\
\text { validade e tipo; } \\
\text { - Controle do Estoque; }\end{array}$ & $\begin{array}{ll}\text { - } & \text { Abastecer as Unidades } \\
& \text { Administrativas } \\
\text { - } & \text { Abastecer as UBSF } \\
\text { - } & \text { Abastecer as UBS } \\
\text { - } & \text { Abastecer as Policlínicas } \\
\text { - } & \text { Abastecer as USA } \\
& \text { Abastecer as Escolas com } \\
\text { - } & \text { Equipe de Odontologia } \\
& \text { Abastecer o SAMU, MMT } \\
& \text { e CEO }\end{array}$ \\
\hline & $\begin{array}{l}\text { DIMED } \\
\text { DIVPA } \\
\text { SETIN }\end{array}$ & DIVAL & DIVAL \\
\hline & \multicolumn{3}{|c|}{ Logística Reversa } \\
\hline & \multicolumn{3}{|c|}{$\begin{array}{l}\text { - Recolher os medicamentos vencidos ou com avarias nos Estabelecimentos Assistenciais } \\
\text { de Saúde }\end{array}$} \\
\hline & \multicolumn{3}{|c|}{ DIVAL } \\
\hline
\end{tabular}

Fonte: Elaborado pelo Autor, 2017. 


\subsection{PROCESSO DE PESQUISA}

O processo de pesquisa ou etapas da pesquisa científica, segundo Zenella (2009) é composto por três momentos intimamente relacionados: (1) planejamento; (2) execução e (3) comunicação dos resultados.

O planejamento é a fase inicial da pesquisa, onde uma série de decisões irá nortear todo o processo da pesquisa. A execução é quando o pesquisador entra no campo da pesquisa propriamente dita, seguindo as orientações do planejamento. $E$ por ultimo a comunicação dos resultados, que é a fase redacional, podendo ser um trabalho de conclusão de curso (TCC), relatório, artigo científico, dissertação ou tese (ZANELLA, 2009).

Ainda segundo Zanella (2009) o planejamento da pesquisa é a fase mais complexa e a mais difícil de todo o processo de investigação, tendo como produto final o Projeto de Pesquisa. De forma sucinta, a Figura 9 apresenta o primeiro momento, a fase de planejamento, culminando na Pesquisa propriamente dita. 
Figura 9 - Fases do Planejamento do Projeto de Pesquisa

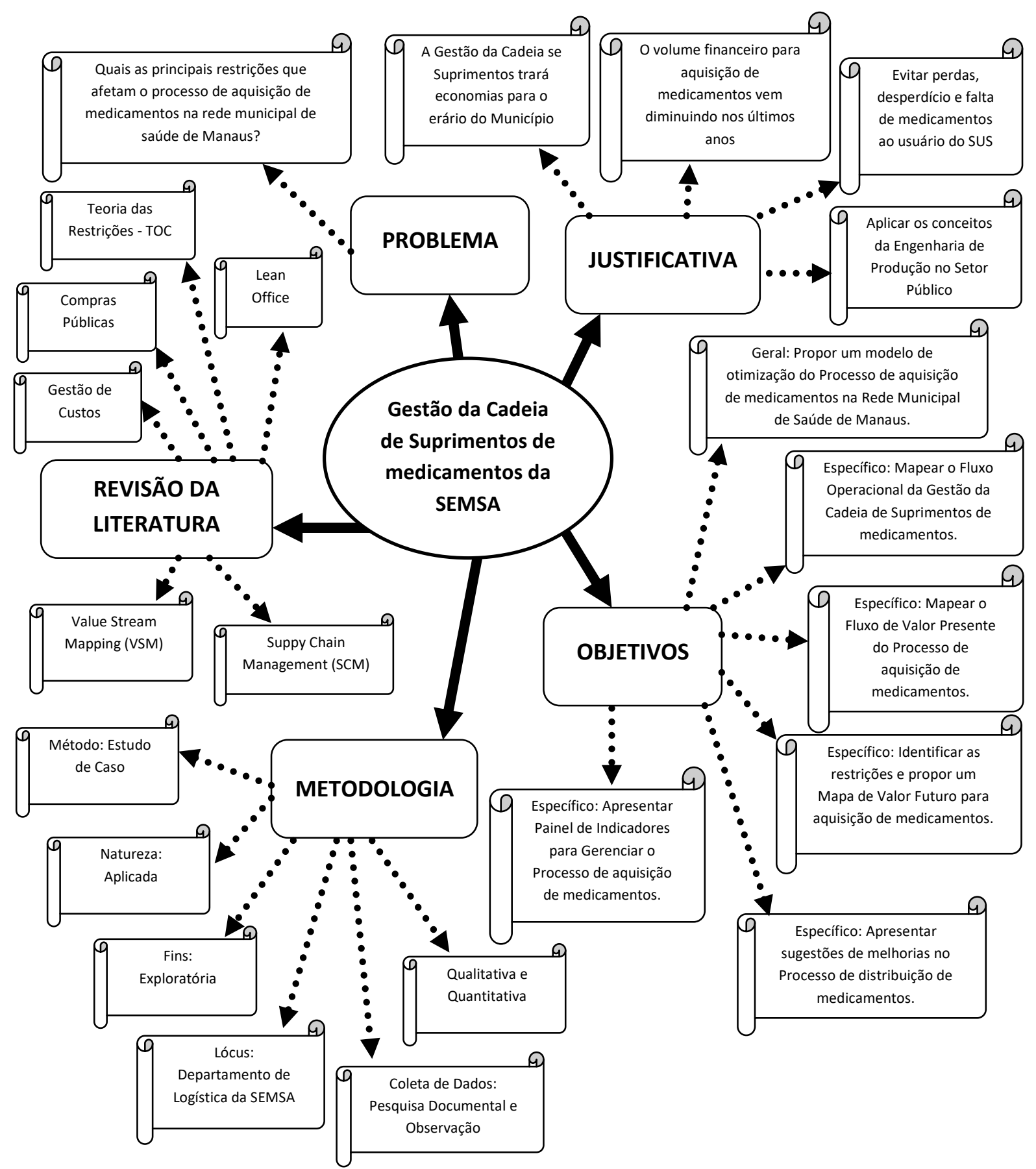

Fonte: Elaborador pelo Autor, 2017.

Concernente ao processo de investigação que objetivou chegar ao escopo do da Pesquisa e responder a pergunta-problema, a pesquisa ficou estruturada em cinco etapas, conforme pode ser observado na Figura 10. Para cada uma destas etapas há um detalhamento de atividades que foram empreendidas. 
Figura 10 - Detalhes das Etapas da Pesquisa

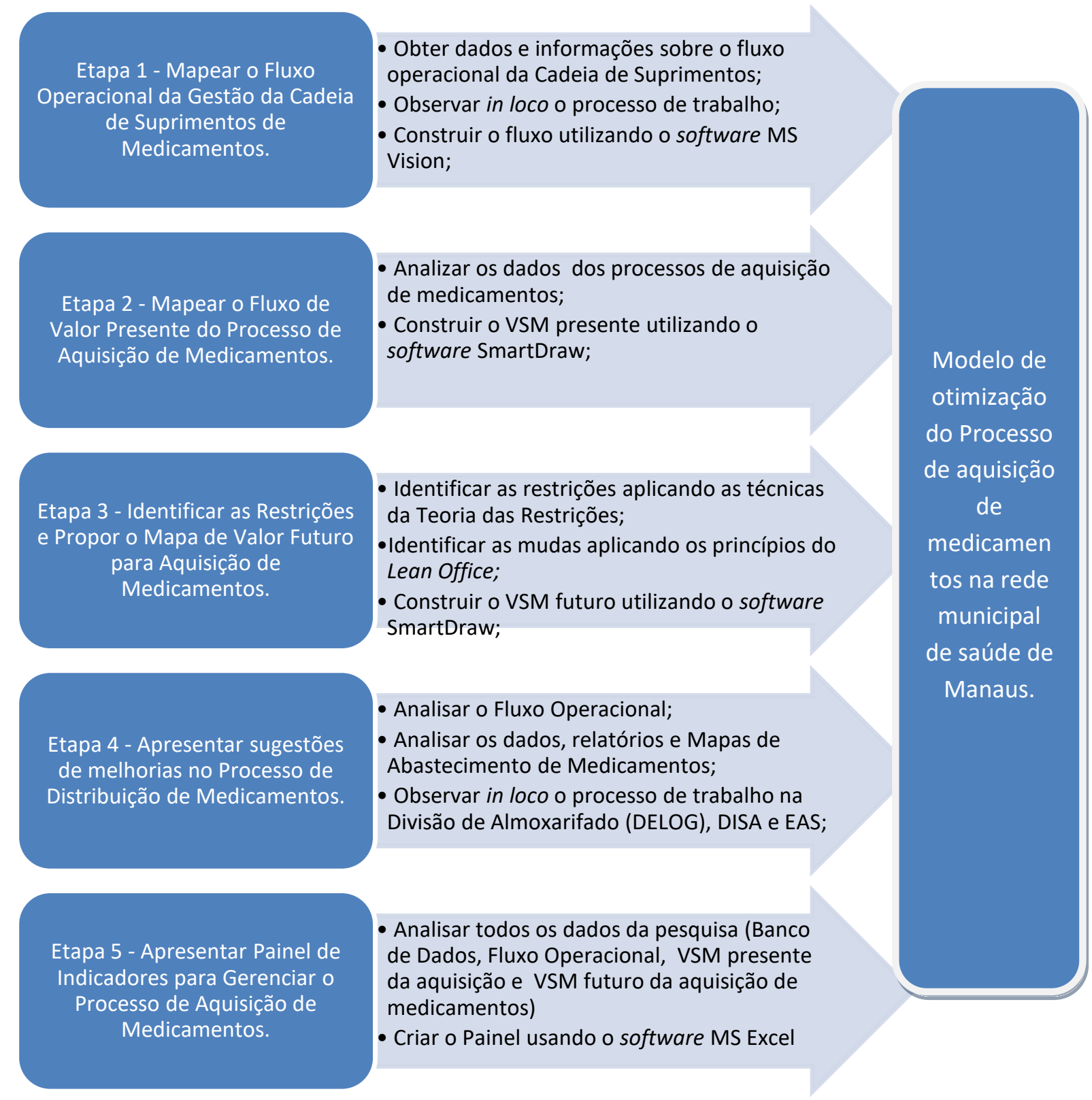

Fonte: Elaborador pelo Autor, 2017.

\subsection{INSTRUMENTO DE COLETA DE DADOS}

Prodanov e Freitas (2013) definem a coleta de dados como a fase da pesquisa cujo propósito é obter informações da realidade. É a fase em que se reúnem dados através de técnicas específicas. Estas técnicas são um conjunto de preceitos ou procedimento de que se serve uma ciência ou arte. Toda ciência utiliza inúmeras técnicas na obtenção de seus propósitos (TURRIONI; MELLO, 2012). 
Turrioni e Mello (2012) afirmam que a pesquisa pode usar uma ou mais fonte para coleta de dados. Moresi (2003), Gil (2010) e Yin (2010) ressaltam que o estudo de caso pode empregar várias técnicas para coletar dados: entrevistas, observação, estudo de campo, questionários, roteiros e informações de arquivo/documentação etc.

Para esta Pesquisa foram usadas a observação e a pesquisa documental como técnica para coleta de dados.

Zanella (2009) afirma que observação utiliza o sentido visual para obter informações da realidade, já Turrioni e Mello (2012) e Prodanov e Freitas (2013) ampliam o conceito, afirmando que a observação utiliza os sentidos para obtenção de dados de determinados aspectos da realidade. Prodanov e Freitas (2013) são tácitos ao afirmarem que a observação como técnica de coleta de dados não consiste apenas em ver ou até mesmo ouvir, mas em examinar os fatos ou fenômenos do objeto de estudo ou pesquisa.

Entretanto, para a observação ser considerada um instrumento válido cientificamente como técnica de coleta de dados, é preciso alguns critérios, como apontam Turrioni e Mello (2012) e Prodanov e Freitas (2013): (1) servir a um objetivo preestabelecido, (2) ser planejada, (3) ser registrada de forma sistemática, (4) ser passível de verificação e controles.

A pesquisa documental se utiliza de fontes documentais. Os dados documentais (qualitativos ou quantitativos), podem ser encontrados junto à Empresa, como por exemplo, os relatórios e manuais da organização, relatórios de estoques, de usuários, relatório de entrada e saída de recursos financeiros (ZANELLA, 2009).

A característica da pesquisa documental é que a fonte de coleta de dados está restrita a documentos, escritos ou não, constituindo o que se denomina de fontes primárias. Estas podem ser feitas no momento em que o fato ou fenômeno ocorre, ou depois (TURRIONI; MELLO, 2012).

Os dados que serviram de fonte primária para a pesquisa documental foram: (1) Processos Administrativos para aquisição de medicamentos; (2) Memorando internos do DELOG; (3) Base de dados Setor de Processos/DELOG; (4) Sistema de Protocolo Integrado da Prefeitura Municipal de Manaus (PROTUS); (5) Diário Oficial do Município de Manaus (DOM); (6) Relatório de Gestão da Secretaria Municipal de 
Saúde de Manaus; (7) Sistema de Estoque (SisEstoque); (8) Mapas de Abastecimento dos Estabelecimentos Assistenciais de Saúde.

Estes dados ficaram restritos ao recorte temporal de 2013 a 2015, devido à impossibilidade de analisar todo o ano de 2016, tendo em vista que muitos dos Processos de Aquisição de Medicamentos ainda não foram completados, estando ainda sendo efetivamente entregues ao longo deste ano de 2017.

Para edição de Fluxograma Operacional foi utilizado o software Microsoft Visio. Para construção do VSM presente e VSM futuro foi utilizado o software SmartDraw (www.smartdraw.com). Os softwares Microsoft Excel e Microsoft Access foram utilizados para criação de Banco de Dados, análises estatísticas e criação de gráficos.

\subsection{ANÁLISE DOS RESULTADOS}

Eisenhard (1989) apud Turrioni e Mello (2012) e Yin (2010) afirmam que a análise dos dados da pesquisa é o ponto nevrálgico na construção de teorias a partir do estudo de caso, devido a análise das evidências serem um dos aspectos menos explorados e mais complexos ao realizar estudos de caso.

\subsubsection{Análise dos Dados Qualitativos}

A análise dos dados qualitativos foi feita obedecendo as seguintes etapas:

- Primeiro: Organizar os dados em categorias;

- Segundo: Identificar nos dados padrões, tendências, relações, causalidade, tempo, frequência, etc.

- Terceiro: Sistematizar e agrupar estas informações em forma de Tabela Dinâmica;

\subsubsection{Análise dos Dados Quantitativos}

A análise dos dados quantitativos obedeceu as seguintes etapas:

- Primeiro: Criação de Banco de Dados com registro de todos os dados coletados usando o software MS Excel;

- Segundo: Agrupar os dados através de Tabelas de Frequência; 
- Terceiro: Aplicar técnicas de mensuração estatísticas: moda, mediana, média, usando o software MS Excel;

- Quarto: Analisar e interpretar os dados;

\subsubsection{Análise das Restrições}

Para análise das restrições foi aplicado as cinco etapas para implementação da Teoria das Restrições (TOC), conforme modelo expresso na Revisão da Literatura.

3.5.4 Análise do Mapeamento do Fluxo de Valor (VSM)

Após a criação do VSM presente através do software SmartDraw, foi feito uma análise dos processos que não agregavam valor, eliminando as mudas através dos princípios do Lean Office, sugerindo sua eliminação, substituição ou melhoria através da construção do VSM futuro.

\subsubsection{VSM Futuro}

A partir da construção do VSM Futuro da Gestão da Cadeia de Suprimentos de Medicamento foi proposto o Modelo de Otimização do Processo de Aquisição de Medicamentos na Rede Municipal de Saúde de Manaus.

\subsubsection{Painel de Indicadores}

O Painel de Indicadores compreende um conjunto de indicadores que servirão como referencial para tomada de decisão na Gestão da Cadeia de Suprimentos. Foi desenvolvido a partir dos dados sistematizados na pesquisa. O painel consiste de uma Planilha Eletrônica desenvolvido no MS Excel contendo: (1) Nome, (2) Formula, (3) Escala, (4) Frequência (5) Fonte. 


\section{GESTÃO DA CADEIA DE SUPRIMENTOS DE MEDICAMENTOS}

\subsection{EMPRESA FOCAL: SECRETARIA MUNICIPAL DE SAÚDE DE MANAUS}

A Secretaria Municipal de Saúde de Manaus (SEMSA), criada através da Lei no 1.240 de 20 de novembro de 1975 (MANAUS, 2013), é o Órgão competente dentro da Estrutura Administrativa da Prefeitura Municipal de Manaus para execução de políticas e serviços públicos de saúde no município de Manaus (MANAUS, 2015).

O planejamento estratégico da SEMSA ${ }^{21}$ corrobora para melhor compreensão das responsabilidades e atribuições deste Órgão do Executivo Municipal.

A SEMSA tem como missão institucional executar a política de saúde, no Município de Manaus, com base no modelo de Assistência e Vigilância em Saúde, e prestar serviços que propiciem a promoção, proteção e recuperação da saúde da população como direito de cidadania, tendo o Sistema Único de Saúde como política pública garantidora desse direito.

A visão da SEMSA é ser um referencial de qualidade em Vigilância e Atenção à Saúde e garantir celeridade, eficácia e eficiência no atendimento, bem como a satisfação dos usuários e profissionais de saúde.

São valores da Secretaria Municipal de Saúde:

- Ser transparente, resolutiva e participativa;

- Eficiência, eficácia e ética;

- Melhoria contínua da qualidade dos serviços;

- Solidariedade, integralidade e humanização;

- Assistência integrada à Vigilância em Saúde.

Na mesma direção, o Regimento Interno preconiza que a SEMSA objetiva cumprir as seguintes finalidades (MANAUS, 2013):

- Planejar, orientar normativamente, coordenar e controlar a execução da Política Municipal de Saúde pelos órgãos e instituições públicas e privadas integrantes do Sistema Único de Saúde;

- Promover políticas públicas de desenvolvimento da saúde mediante a execução de ações integradas de atenção à saúde individual e coletiva, de

\footnotetext{
${ }^{21}$ Disponível em: < http://semsa.manaus.am.gov.br/nossa-historia/ >. Acesso em 19.out.2016
} 
vigilância em saúde, de controle de endemias e de qualificação e valorização dos servidores;

Para operacionalizar este Planejamento Estratégico, a SEMSA conta com uma estrutura administrativa preconizada pelo seu Regimento Interno (MANAUS, 2013). Segundo Manaus (2013) a estrutura da SEMSA é basicamente dividida em quatro Órgãos ou áreas hierarquicamente abaixo do Secretário Municipal de Saúde, conforme pode ser visto no Quadro 17.

Quadro 17 - Estrutura Administrativa da SEMSA

\begin{tabular}{|c|c|c|c|c|}
\hline \multicolumn{5}{|c|}{ Secretário Municipal de Saúde } \\
\hline Órgãos & $\begin{array}{c}\text { Órgão } \\
\text { Colegiado }\end{array}$ & $\begin{array}{c}\text { Órgãos de } \\
\text { Assistência e } \\
\text { Assessoramento }\end{array}$ & $\begin{array}{c}\text { Órgãos de Apoio à } \\
\text { Gestão }\end{array}$ & $\begin{array}{c}\text { Órgãos de } \\
\text { Atividades } \\
\text { Finalísticas }\end{array}$ \\
\hline Subsecretaria & -- & -- & $\begin{array}{c}\text { Subsecretaria de } \\
\text { Gestão } \\
\text { Administrativa e } \\
\text { Planejamento. }\end{array}$ & $\begin{array}{c}\text { Subsecretaria de } \\
\text { Gestão da Saúde. }\end{array}$ \\
\hline & $\begin{array}{c}\text { Fazem parte o } \\
\text { Conselho } \\
\text { Municipal de } \\
\text { Saúde e a } \\
\text { Comissão de } \\
\text { Licitação. }\end{array}$ & $\begin{array}{c}\text { Estão diretamente } \\
\text { ligados ao } \\
\text { Gabinete do } \\
\text { Secretário. }\end{array}$ & $\begin{array}{c}\text { Fazem parte desta } \\
\text { Subsecretaria os } \\
\text { Departamentos que } \\
\text { compõem a área } \\
\text { meio da Gestão. }\end{array}$ & $\begin{array}{c}\text { Fazem parte desta } \\
\text { Subsecretaria os } \\
\text { Departamentos que } \\
\text { fazem a gestão da } \\
\text { área fim da } \\
\text { Secretaria. }\end{array}$ \\
\hline Exemplo: & $\begin{array}{c}\text { Conselho } \\
\text { Municipal de } \\
\text { Saúde, } \\
\text { Comissão de } \\
\text { Licitação. }\end{array}$ & $\begin{array}{c}\text { Assessoria de } \\
\text { Comunicação. }\end{array}$ & $\begin{array}{c}\text { Chefia de } \\
\text { Gabinete, } \\
\text { Departamento de } \\
\text { Logística, etc. }\end{array}$ & $\begin{array}{c}\text { Departamento de } \\
\text { Distritos de Saúde, } \\
\text { Unidades de Saúde, } \\
\text { etc. }\end{array}$ \\
\hline
\end{tabular}

Fonte: Elaborado pelo Autor, 2017.

Para garantir a prestação de serviços de promoção, proteção e recuperação da saúde da população de Manaus, a SEMSA conta com mais de 11 mil servidores $^{22}$ lotados em uma Unidade Administrativa ou Estabelecimentos Assistenciais de Saúde (EAS). Conforme o Relatório de Gestão de $2014^{23}$ da SEMSA, a Rede Física de Saúde é composta pelos seguintes Estabelecimentos Assistenciais de Saúde e Unidades Administrativas, conforme Quadro 18.

\footnotetext{
22 Disponível em: < http://semsa.manaus.am.gov.br/nossa-historia/ >. Acesso em 19.out.2016

${ }^{23}$ Relatório de Gestão de 2015 da SEMSA ainda não foi publicado.
} 
Quadro 18 - Rede Física de Saúde

\begin{tabular}{|l|c|}
\hline \multicolumn{1}{|c|}{ Descrição } & Qtde. \\
\hline Central de Regulação & 1 \\
\hline Central de Regulação Médica das Urgências & 1 \\
\hline Centro de Atenção Psicossocial & 2 \\
\hline Unidade Básica de Saúde & 226 \\
\hline Centro de Especialidade & 6 \\
\hline Hospital & 1 \\
\hline Policlínica & 7 \\
\hline Posto de Saúde & 18 \\
\hline Unidades Administrativas & 6 \\
\hline Unidade de Apoio Diagnose e Terapia & 5 \\
\hline Unidade de Atenção a Saúde Indígena & 3 \\
\hline Unidade de Vigilância em Saúde & 1 \\
\hline Unidade Móvel de Urgência & 66 \\
\hline Unidade Móvel Fluvial & 1 \\
\hline Unidade Móvel Terrestre & 5 \\
\hline \multicolumn{2}{|c|}{ Fonte: Relatório de Gestão SEMSA, 2014. }
\end{tabular}

Os Estabelecimentos Assistenciais de Saúde compõem uma rede com mais de duzentos e cinquenta Unidades de Saúde com tipologia variada (UBS, UBSF, Policlínica, CEO, etc.), dependendo do seu escopo, atuação e capacidade instalada, estando vinculados aos Distritos de Saúde.

Por uma questão técnico-operacional, a SEMSA possui cinco unidades administrativas descentralizadas, denominadas Distritos de Saúde (DISA), que são subordinados a Subsecretaria de Gestão da Saúde. Os Distritos de Saúde estão distribuídos taticamente em cada zona geográfica da Cidade, e coordenam um grupo de EAS que estão sob sua "jurisdição", ou seja, na sua área geográfica. Atualmente os Distritos de Saúde são: DISA Norte, DISA Sul, DISA Leste, DISA Oeste e DISA Fluvial. 
Quadro 19 - Distrito de Saúde x Exemplo de EAS

\begin{tabular}{|c|c|c|c|c|c|}
\hline DISA & Norte & Sul & Leste & Oeste & Fluvial \\
\hline \multirow{7}{*}{ 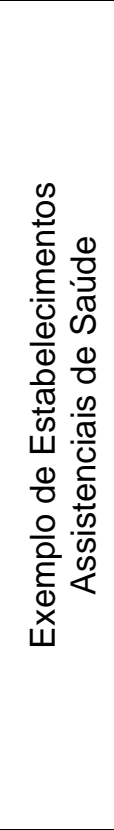 } & $\begin{array}{c}\text { Policlínica } \\
\text { Anna Barreto }\end{array}$ & $\begin{array}{c}\text { Policlínica } \\
\text { Antônio Reis }\end{array}$ & $\begin{array}{l}\text { Policlínica } \\
\text { Ivone Lima }\end{array}$ & $\begin{array}{c}\text { Policlínica } \\
\text { Djalma Batista }\end{array}$ & $\begin{array}{l}\text { Unidade Móvel } \\
\text { Fluvial }\end{array}$ \\
\hline & $\begin{array}{l}\text { UBS Armando } \\
\text { Mendes }\end{array}$ & $\begin{array}{l}\text { UBS Megumo } \\
\text { Kado }\end{array}$ & $\begin{array}{l}\text { UBS Avelino } \\
\text { Pereira }\end{array}$ & $\begin{array}{l}\text { UBS Leonor de } \\
\text { Freitas }\end{array}$ & $\begin{array}{l}\text { Posto de } \\
\text { Saúde Rural } \\
\text { Guajará }\end{array}$ \\
\hline & $\begin{array}{l}\text { UBS Áugias } \\
\text { Gadelha }\end{array}$ & UBS Petropolis & $\begin{array}{l}\text { UBS Geraldo } \\
\text { Magela }\end{array}$ & $\begin{array}{l}\text { UBS Mansour } \\
\text { Bulbol }\end{array}$ & $\begin{array}{l}\text { Posto de } \\
\text { Saúde Rural } \\
\text { Santa Maria }\end{array}$ \\
\hline & $\begin{array}{l}\text { Laboratório } \\
\text { Distrital Norte }\end{array}$ & $\begin{array}{l}\text { Laboratório } \\
\text { Distrital Sul }\end{array}$ & $\begin{array}{l}\text { Laboratório } \\
\text { Distrital Leste }\end{array}$ & $\begin{array}{l}\text { Laboratório } \\
\text { Distrital Oeste }\end{array}$ & $\begin{array}{c}\text { Posto de } \\
\text { Saúde Rural } \\
\text { Costa do Arara }\end{array}$ \\
\hline & UBSF-N01 & $\begin{array}{c}\text { Centro de } \\
\text { Atenção } \\
\text { Psicossocial Sul } \\
\end{array}$ & $\begin{array}{l}\text { Laboratório de } \\
\text { Citopatologia }\end{array}$ & $\begin{array}{c}\text { Centro } \\
\text { Especializado } \\
\text { de Reabilitação }\end{array}$ & $\begin{array}{l}\text { Posto de } \\
\text { Saúde Rural } \\
\text { Jatuarana }\end{array}$ \\
\hline & UBSF-N04 & UBSF-S42 & UBSF-L10 & UBSF-O15 & $\begin{array}{l}\text { Posto de } \\
\text { Saúde Rural } \\
\text { Mipindiaú }\end{array}$ \\
\hline & UBSF-N09 & UBSF-S04 & UBSF-L13 & UBSF-O21 & $\begin{array}{c}\text { Posto de } \\
\text { Saúde Rural N. } \\
\text { Sra. De Fátima }\end{array}$ \\
\hline
\end{tabular}

Fonte: Manaus, 2013.

Todas as Unidades Administrativas bem como todos os Estabelecimentos Assistenciais de Saúde recebem mensalmente suprimentos de material de expediente e limpeza. Especificamente os Estabelecimentos Assistenciais de Saúde além de material de expediente, também recebem medicamentos e insumos para saúde (seringas, agulha, luvas, gazes, preservativos, etc.).

Em cada EAS há distribuição de medicamentos aos usuários do SUS (conforme receita médica) ou se não distribuem, ao menos há a necessidade de terem os medicamentos e demais insumos para a saúde, como é o caso do Serviço de Atendimento Móvel de Urgência (SAMU), Centro de Especialidade Odontológica (CEO) e Maternidade Moura Tapajós (MMT).

O Departamento de Logística (DELOG) é o responsável pela gestão do suprimento de material de expediente, limpeza, insumos para saúde e medicamentos na Secretaria Municipal de Saúde de Manaus.

\subsubsection{Gestão da Cadeia de Suprimentos: Departamento de Logística (DELOG)}

O Departamento de Logística (DELOG) é o setor competente, dentro da estrutura administrativa da SEMSA, para Gerir toda a Cadeia de Suprimentos da 
Secretaria Municipal de Saúde de Manaus, desde a aquisição (logística de suprimentos), recebimento e armazenagem (logística interna), distribuição para a Rede-SEMSA (logística de distribuição) e recolhimento dos inservíveis (logística reversa). Cada etapa da Cadeia Logística pode ser visualizada no Quadro 16.

Dentro da estrutura administrativa da SEMSA, o Departamento de Logística está vinculado a Subsecretaria de Gestão Administrativa e Planejamento (SUBGAP), que compõe os Órgãos de Apoio à Gestão. Manaus (2013) preceitua o DELOG com a seguinte estrutura organizacional:

Figura 11 - Estrutura Administrativa do DELOG

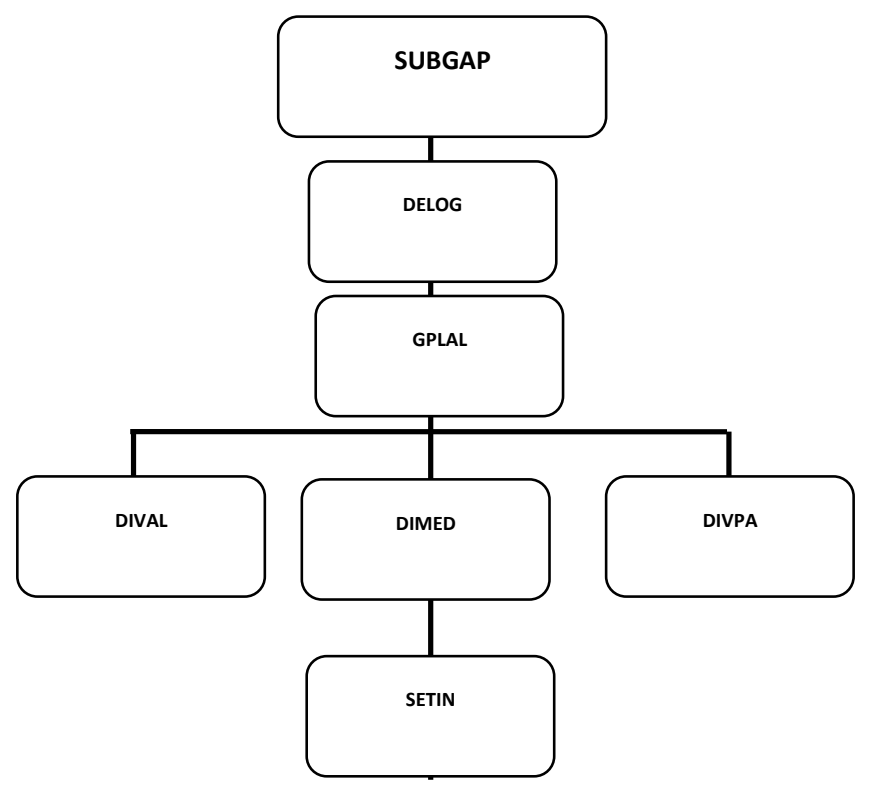

Fonte: Manaus, 2013.

A Portaria no $328 / 2014-G A B I N / S E M S A$ de 30 de abril de $2014^{24}$ alterou a estrutura administrativa do DELOG, retirando de sua competência a Divisão de Compras (DICOM), Setor de Banco de Preços e a Divisão de Registro de Preços (DIREP), passando para a competência do Departamento de Administração e Infraestrutura.

O Departamento de Logística é conduzido por um Diretor devidamente nomeado em Portaria e tem a responsabilidade de gerir toda a Cadeia Logística da SEMSA. Compete ao DELOG (Manaus, 2013):

- Coordenar, controlar e monitorar as atividades a serem executadas sob sua direção;

\footnotetext{
${ }^{24}$ Publicado no Diário Oficial de Manaus em 7 de maio de 2014. Ano XV. Edição 3404.
} 
- Planejar, coordenar, monitorar e avaliar as ações inerentes ao sistema logística da Secretaria, em conjunto com outras Diretorias;

- Efetuar a articulação com as Diretorias dos Distritos de Saúde, objetivando melhorar o desempenho de ciclo logístico de insumos em geral;

- Coordenar a solicitação para a aquisição de medicamentos, insumos, produtos e demais matérias e equipamentos com base nos indicadores de consumo;

- Elaborar normas para acompanhamento e controle da logística de suprimento da Secretaria e submeter à autoridade superior;

- Coordenar e supervisionar a área de planejamento em logística, compras, banco de preços, medicamentos e insumos em geral, almoxarifado e patrimônio da estrutura operacional da Secretaria;

- Coordenar a aquisição de medicamentos, insumos, produtos e demais materiais e equipamentos com base nos indicadores de consumo;

- Propor à autoridade competente os atos administrativos para a normatização de procedimentos e funcionamento do sistema de logística;

- Zelar pela organização física, sinalização do ambiente e procedimentos de estocagem e descarte de itens, segundo as normas vigentes de manuseio, embalagem e armazenamento;

- Coordenar a elaboração de relatórios periódicos e anual;

- Desenvolver outras atividades correlatas.

A Gerência de Planejamento em Logística (GPLAL) tem a responsabilidade de elaborar e executar o planejamento estratégico do Departamento em conjunto com o Diretor. Compete a Gerencia de Planejamento e Logística (Manaus, 2013):

- Coordenar as atividades de planejamento nas áreas de logística de medicamentos, produtos para saúde e insumos em geral;

- Planejar, coordenar e controlar os processos de trabalho interno do Departamento inerentes à parte administrativa;

- Coordenar o processo de aquisição e distribuição dos materiais necessários para abastecimento da rede da Secretaria;

- Gerenciar o fluxo interno de processos administrativos no Departamento; 
- Participar do planejamento, coordenação, elaboração e apresentação de propostas e projetos para captação de recursos destinados a aquisição de medicamentos, produtos para saúde e insumos em geral;

- Apresentar propostas para implantação, desenvolvimento e melhorias dos sistemas de informação destinados ao monitoramento das atividades de logística da Secretaria;

- Coordenar a elaboração de relatórios periódicos;

- Desenvolver outras atividades correlatas.

A Divisão de Medicamentos e Insumos (DIMED) é responsável pela gestão dos medicamentos e demais insumos para saúde (químico, laboratório e odontológico). Atua diretamente com os Distritos de Saúde e as Unidades de Saúde analisando as demandas de consumo e fazendo a aquisição de medicamentos e insumos para toda a Rede-SEMSA. Compete a Divisão de Medicamentos e Insumos (Manaus, 2013):

- Coordenar o processo de logística de medicamentos e produtos para saúde, necessários para abastecimento da rede da Secretaria;

- Acompanhar e monitorar o recebimento e armazenagem de medicamentos e produtos para saúde;

- Participar do planejamento, coordenação, elaboração e apresentação de propostas e projetos para captação de recursos destinados a aquisição de medicamentos e produtos para saúde;

- Promover estratégias e ações para redução das perdas e vencimento de medicamentos e produtos para a saúde;

- Articular com a Gerência de Assistência Farmacêutica e a Comissão de Farmácia e Terapêutica da Secretaria para a promoção do uso racional de medicamentos e produtos para a saúde e participação nos processos de padronização;

- Apresentar propostas para implantação, desenvolvimento e melhorias dos sistemas de informação para o monitoramento das atividades de logística de medicamentos e produtos para a saúde;

- Proceder à análise dos mapas de abastecimento da rede da Secretaria;

- Desenvolver outras atividades correlatas 
A Divisão de Almoxarifado (DIVAL) é responsável pela gestão de todo o material da Central de Abastecimento, especificamente pela Logística Interna, Logística de Distribuição e em alguns casos a Logística Reversa. É da responsabilidade da Divisão de Almoxarifado (Manaus, 2013):

- Coordenar as atividades de logística do Departamento no que se refere ao controle de estoques, recebimento, armazenamento, movimentação, separação e distribuição de medicamentos, produtos para saúde e insumos em geral necessários para abastecimento da rede da Secretaria;

- Supervisionar o adequado recebimento de materiais no almoxarifado, assegurando que o os materiais entregues estejam em conformidade com as especificações constantes no empenho;

- Supervisionar o adequado armazenamento dos materiais, visando preservar sua integridade e segurança;

- Planejar e organizar a disposição das mercadorias estocadas, conforme normas e legislação vigente;

- Orientar a equipe do Almoxarifado quanto aos procedimentos para manuseio e estocagem, visando manter a integridade, características e condições de uso dos materiais;

- Supervisionar o serviço de transporte e entrega de materiais, de acordo com o cronograma de abastecimento;

- Elaborar relatórios de controles de estoque que subsidiem os processos de aquisição de materiais, assim como a distribuição;

- Promover ações para redução das perdas e vencimento de medicamentos, produtos para a saúde e insumos em geral;

- Desenvolver outras atividades correlatas.

A Divisão de Patrimônio (DIVPA) é responsável pela gestão de todo os bens permanentes (patrimônio) da Secretaria. Assim como a Divisão de Almoxarifado, o DIVPA também executa a Logística Interna, Logística de Distribuição e Logística Reversa. Compete Divisão de Patrimônio (Manaus, 2013):

- Coordenar e executar as ações relativas ao processo logístico dos bens móveis permanentes da Secretaria;

- Executar e monitorar a classificação e padronização de materiais, com auxílio das áreas técnicas; 
- Manter sob guarda e conservação os materiais em estoque;

- Planejar e coordenar o inventário físico do patrimônio da Secretaria e informar, anualmente, a situação patrimonial por meio de relatório à Secretaria competente;

- Executar as baixas de bens inservíveis mediante apresentação de documentação pertinente;

- Conferir notas fiscais conforme nota de empenho, providenciando seu atesto;

- Apoiar as áreas técnicas na elaboração de especificações de materiais relativos às categorias controladas pela Divisão para fins de aquisição;

- Desenvolver outras atividades correlatas

O Departamento de Logística (DELOG) exerce papel fundamental na Gestão da Cadeia de Suprimentos, pois é o setor competente, dentro da estrutura administrativa da Secretaria Municipal de Saúde, para gerir toda a cadeia de suprimentos de medicamentos, sendo responsável pelos processos administrativos para licitação de medicamentos; processos administrativos para aquisição de medicamentos através de Ata de Registro de Preços; receber e armazenar os medicamentos; distribuir os medicamentos para a Rede de Estabelecimentos Assistenciais e recolher os medicamentos em caso de perda da validade.

4.1.2 Parceiro Interno na Gestão da Cadeia: Gerência de Assistência Farmacêutica

Diferente do Departamento de Logística que é da atividade meio, a Gerência de Assistência Farmacêutica é da atividade fim, lida diretamente com as demandas de saúde dos usuários da Rede Municipal de Saúde, estando hierarquicamente ligada ao Departamento de Atenção Primária e a Subsecretaria de Gestão da Saúde.

Manaus (2013) confere as seguintes competências à Gerência de Assistência Farmacêutica:

- Elaborar, monitorar e avaliar ações de implantação e implementação da assistência farmacêutica no âmbito municipal;

- Dirigir, coordenar e supervisionar a área de assistência farmacêutica e de farmácia gratuita da estrutura operacional da Secretaria; 
- Planejar, monitorar e avaliar as ações de assistência farmacêutica, garantindo o acesso aos medicamentos padronizados na Relação Municipal de Medicamentos Essenciais - REMUME;

- Desenvolver outras atividades correlatas.

\subsection{DADOS DA GESTÃO DA CADEIA DE SUPRIMENTOS DE MEDICAMENTOS}

A análise dos dados dos Processos Administrativos de aquisição de medicamentos através de Ata de Registro de Preços no período de 2013 a 2015 trazem à luz várias informações relevantes para a tomada de decisão na Gestão da Cadeia de Suprimentos de medicamentos da Secretaria Municipal de Saúde de Manaus.

\subsubsection{Formação dos Bancos de Dados Fontes da Pesquisa}

São três os Bancos de Dados Fontes da Pesquisa (1) Banco de Dados Processos, (2) Banco de Dados Empenhos e (3) Banco de Dados Tramitação Processos. Segue os passos para elaboração dos mesmos.

\subsubsection{Passo 1 - Tratamento Banco de Dados Primário}

O Departamento de Logística, através do Setor de Processos ${ }^{25}$ forneceu o Banco de Dados Primário com as informações pertinentes dos Processos de aquisição de Medicamentos com 324 registros indexados pelo Número do Empenho, conforme Figura 12.

\footnotetext{
${ }^{25}$ O Setor de Processos é um setor administrativo interno do DELOG, ele não está na Estrutura Administrativa da SEMSA. É vinculado à Gerência de Planejamento e Logística, sendo o responsável pela gestão processual de todos os Processos de Aquisição, quer seja de medicamentos, odontológico, expediente, limpeza, etc.
} 
Figura 12 - Banco de Dados Primário

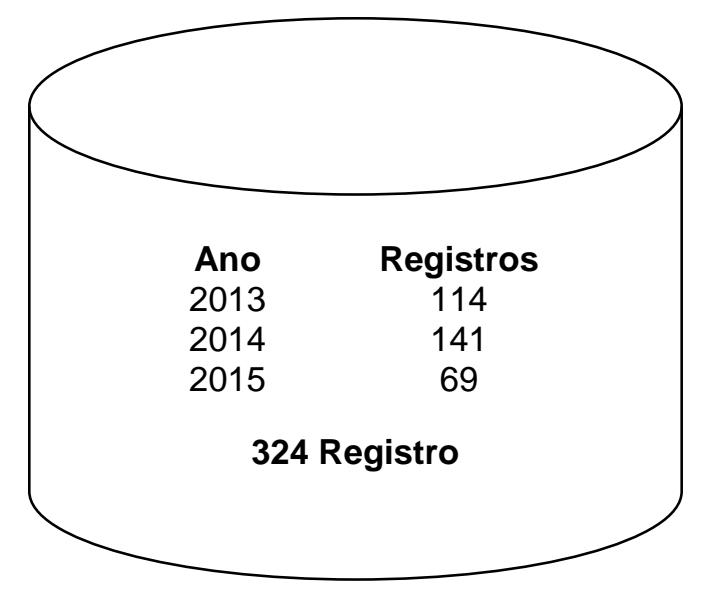

Fonte: Elaborado pelo autor, 2017.

Cada registro do Banco de Dados Primário era composto pelos seguintes Campos:

Quadro 20 - Campos Banco de Dados Primário

\begin{tabular}{|l|l|}
\hline \multicolumn{1}{|c|}{ Campo } & \multicolumn{1}{c|}{ Descrição } \\
\hline EMPENHO & Número do Empenho (chave primária ${ }^{26}$ ) \\
\hline PROCESSO & Número do Processo \\
\hline FORNECEDOR & Nome do Fornecedor \\
\hline DATA_EMPENHO & Data Emissão do Empenho \\
\hline DATA_FORNEC_REC_EMPENHO & Data Fornecedor Recebeu Empenho \\
\hline DESPESA & Descrição da Despesa \\
\hline PROCESSO_DE_PAGAMENTO & Número do Processo de Pagamento \\
\hline VALOR_DO_EMPENHO & Valor do Empenho \\
\hline
\end{tabular}

Fonte: Elaborado pelo autor, 2017.

\subsubsection{Passo 2 - Criação Banco de Dados Processos}

Objetivando modificar a estrutura do Banco de Dados Primário, colocando o Número do Processo Administrativo como Chave Primária ${ }^{27}$, utilizou-se o Software Microsoft Access para criar o Banco de Dados Processos, obtendo o seguinte resultado, conforme Figura 13.

\footnotetext{
${ }^{26}$ Chave Primária num Banco de Dados é um Registro Único, não se repete em nenhum outro campo.

27 Um Processo de Aquisição pode gerar " $n$ " Empenhos, logo, Empenhos diferentes podem ter o número do Processo Administrativo iguais. Por isso a necessidade de indexar o Banco de Dados pelo Número do Processo.
} 
Figura 13 - Banco de Dados Processos - I

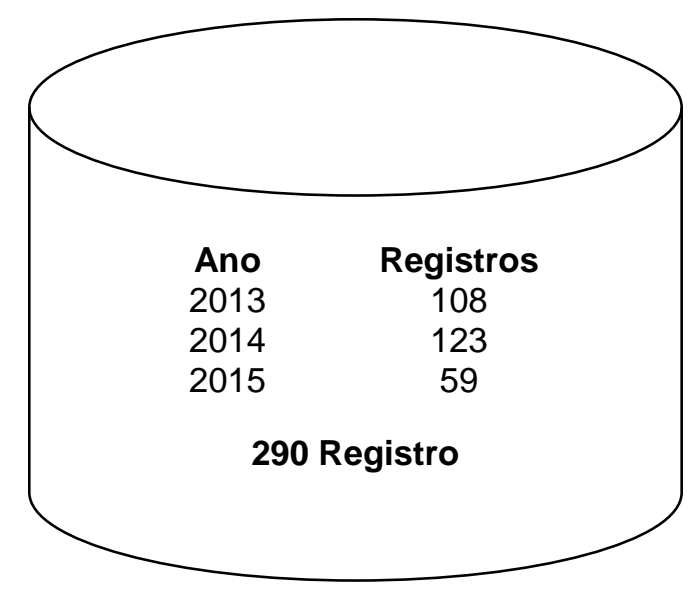

Fonte: Elaborado pelo autor, 2017.

4.2.1.3 Passo 3 - Ampliando Banco de Dados Processos: PROTUS

$\mathrm{Na}$ sequência, empreendeu-se uma pesquisa por Número do Processo junto ao Sistema de Protocolo - PROTUS a fim de coletar mais dados dos Processos Administrativos, tendo como resultado o incremento dos seguintes dados: (1) Data que o Processo foi formalizado no PROTUS; (2) Número do Memorando que gerou o Processo Administrativo; (3) Descrição do Processo Administrativo.

\subsubsection{Passo 4 - Ampliando Banco de Dados Processos: Pesquisa Documental}

Em ato contínuo, empreendeu-se uma pesquisa documental nos Memorandos expedidos pelo Departamento de Logística, usando como referência o Número de Memorando fornecido pelo PROTUS, tendo como resultado a inclusão dos seguintes dados: (1) Data Expedição do Memorando; (2) Descrição do Memorando.

Com estes últimos dados, finalizou-se a construção do Banco de Dados Processos, contendo os seguintes campos: 
Quadro 21 - Campos Banco de Dados Processos

\begin{tabular}{|c|c|}
\hline Campo & Descrição \\
\hline ANO & Ano do Processo \\
\hline PROCESSO & Número do Processo (chave primária) \\
\hline NR_MEMORANDO & Número do Memorando \\
\hline DATA_MEMORANDO & Data Expedição do Memorando \\
\hline DESCRICAO_MEMORANDO & Descrição do Assunto do Memorando \\
\hline DATA_FORMALIZ_PROTUS & Data da Formalização do Processo \\
\hline DESCRICAO_PROCESSO_PROTUS & Descrição do Processo \\
\hline QTDE_EMPENHO & Quantidade de Empenhos Gerados \\
\hline DATA_EMPENHO & Data Emissão do Empenho \\
\hline DATA_FORNEC_REC_EMPENHO & Data Fornecedor Recebeu Empenho \\
\hline NR_EMPENHO_1 & Número Empenho 1 \\
\hline VALOR_EMPENHO_1 & Valor Empenho 1 \\
\hline NR_EMPENHO_2 & Número Empenho 2 \\
\hline VALOR_EMPENHO_2 & Valor Empenho 2 \\
\hline NR_EMPENHO_3 & Número Empenho 3 \\
\hline VALOR_EMPENHO_3 & Valor Empenho 3 \\
\hline NR_EMPENHO_4 & Número Empenho 4 \\
\hline VALOR_EMPENHO_4 & Valor Empenho 4 \\
\hline FORNECEDOR & Nome do Fornecedor \\
\hline
\end{tabular}

Fonte: Elaborado pelo autor, 2017.

\subsubsection{Passo 5 - Finalizando Banco de Dados Processos}

Analisando o Banco de Dados Processos verificou-se que sessenta e nove

(69) registros não tratavam de Processo Administrativo para Aquisição de Medicamentos, sendo:

Quadro 22 - Registros Indevidos

\begin{tabular}{|c|l|}
\hline $\begin{array}{c}\text { Quantidade } \\
\text { Registros }\end{array}$ & \multicolumn{1}{c|}{ Descrição } \\
\hline 10 & Memorando que gerou Processo de Aquisição não era do DELOG. \\
\hline 1 & $\begin{array}{l}\text { Não consta no PROTUS o Número do Memorando, o que impossibilitou de } \\
\text { checar se realmente tratava-se de um Memo. de Aquisição de Medicamento. }\end{array}$ \\
\hline 7 & $\begin{array}{l}\text { Não foi encontrado o Memorando no DELOG, o que impossibilitou de checar se } \\
\text { realmente tratava-se de um Memo. de Aquisição de Medicamento. }\end{array}$ \\
\hline 51 & $\begin{array}{l}\text { Memorando do DELOG não se trata de Aquisição de Medicamentos, tratava-se } \\
\text { de outra coisa, por exemplo: (a) Adesão a Ata; (b) Licitação, (c) Aquisição de } \\
\text { Odonto, Químico, Expediente. }\end{array}$ \\
\hline
\end{tabular}

Fonte: Elaborado pelo autor, 2017. 
Excluindo estes 69 registros indevidos, o Banco de Dados Processos finalizou com 221 registros, representando o universo de Processos Administrativos pesquisados no recorte temporal de 2013 a 2015.

Figura 14 - Banco de Dados Processos - II

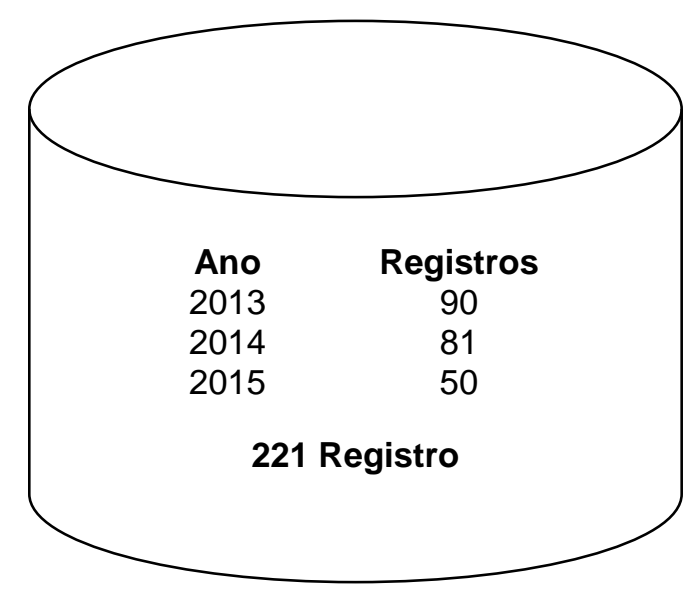

Fonte: Elaborado pelo autor, 2017.

4.2.1.6 Passo 6 - Criação Banco de Dados Empenhos

Devido à necessidade de tratamento específico dos dados dos Empenhos, utilizou-se o Software Microsoft Access para criar o Banco de Dados Empenhos, a partir do Banco de Dados Processos, obtendo o seguinte resultado, conforme Figura 15.

Figura 15 - Banco de Dados Empenhos

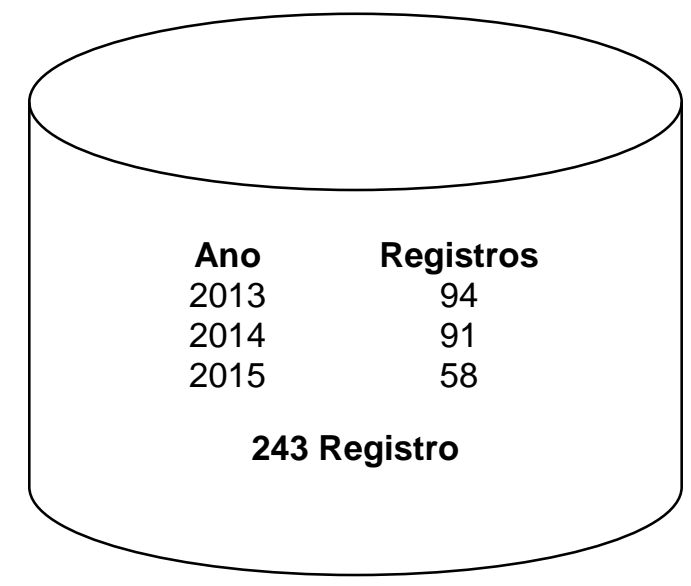

Fonte: Elaborado pelo autor, 2017. 
Na sequência, empreendeu-se uma pesquisa pelo Número do Empenho junto ao Sistema de Estoque - SisEstoque ${ }^{28}$, tendo como resultado o incremento dos seguintes dados: (1) Data do primeiro fornecimento de medicamentos ao DELOG; (2) Data do último fornecimento de medicamentos ao DELOG; (3) Quantidade de fornecimentos para o mesmo Empenho; (4) Valor total.

Com estes últimos dados, finalizou-se a construção do Banco de Dados Empenhos, contendo os seguintes campos:

Quadro 23 - Campos Banco de Dados Empenhos

\begin{tabular}{|l|l|}
\hline \multicolumn{1}{|c|}{ Campo } & \multicolumn{1}{c|}{ Descrição } \\
\hline ANO & Ano do Processo \\
\hline NUMERO_EMPENHO & Número do Empenho (chave primária) \\
\hline PROCESSO & Número do Processo \\
\hline DATA_EMPENHO & Data Emissão do Empenho \\
\hline VALOR_EMPENHO & Valor do Empenho \\
\hline DATA_PRIMEIRO_FORNECIMENTO_DELOG & $\begin{array}{l}\text { Data do Primeiro Fornecimento de Material } \\
\text { ao DELOG }\end{array}$ \\
\hline DATA_ULTIMO_FORNECIMENTO_DELOG & $\begin{array}{l}\text { Data do Último Fornecimento de Material } \\
\text { ao DELOG }\end{array}$ \\
\hline QTDE_FORNECIMENTOS & $\begin{array}{l}\text { Quantas vezes o Fornecedor Forneceu } \\
\text { Material no DELOG ref. Mesmo Empenho }\end{array}$ \\
\hline VALOR_TOTAL_FORNECIDO & $\begin{array}{l}\text { Valor Total de todos os Fornecimentos de } \\
\text { Material ref. Mesmo Empenho. }\end{array}$ \\
\hline
\end{tabular}

Fonte: Elaborado pelo autor, 2017.

\subsubsection{Passo 8 - Banco de Dados Tramitação Processos}

O Departamento de Tecnologia da Informação forneceu o Banco de Dados Tramitação Processos, tendo como fonte o Sistema de Protocolo - PROTUS, com a tramitação de todos os Processos de Aquisição de Medicamentos, conforme Banco de Dados Processos, desde a data de sua formalização até a data de arquivo do Processo Administrativo, com o tempo que passou em cada Departamento/Setor e o tempo de trânsito entre um e outro Departamento/Setor.

\footnotetext{
28 Os dados analisados no Sistema de Estoque foram de 01/01/2013 a 31/12/2016, devido à possibilidade de um Empenho de 2015 ser finalizado em 2016.
} 
Quadro 24 - Campos Banco de Dados Tramitação Processos

\begin{tabular}{|l|l|}
\hline \multicolumn{1}{|c|}{ Campo } & \multicolumn{1}{c|}{ Descrição } \\
\hline PROCESSO & Número do Processo \\
\hline SEQ & Número Sequencial \\
\hline SETOR & Nome do Setor \\
\hline ENTRADA_SETOR & Data da Entrada no Setor \\
\hline SAIDA_SETOR & Data da Saída do Setor \\
\hline TEMPO_NO_SETOR & Tempo que permaneceu no Setor (dias) \\
\hline TEMPO_TRANSITO & $\begin{array}{l}\text { Tempo de Transito entre um Setor e o } \\
\text { Outro (dias) }\end{array}$ \\
\hline
\end{tabular}

Fonte: Elaborado pelo autor, 2017.

Finalizando, assim, a construção dos Bancos de Dados Fontes, que subsidiaram os resultados da pesquisa, conforme expostos na sequência.

Figura 16 - Banco de Dados Fontes
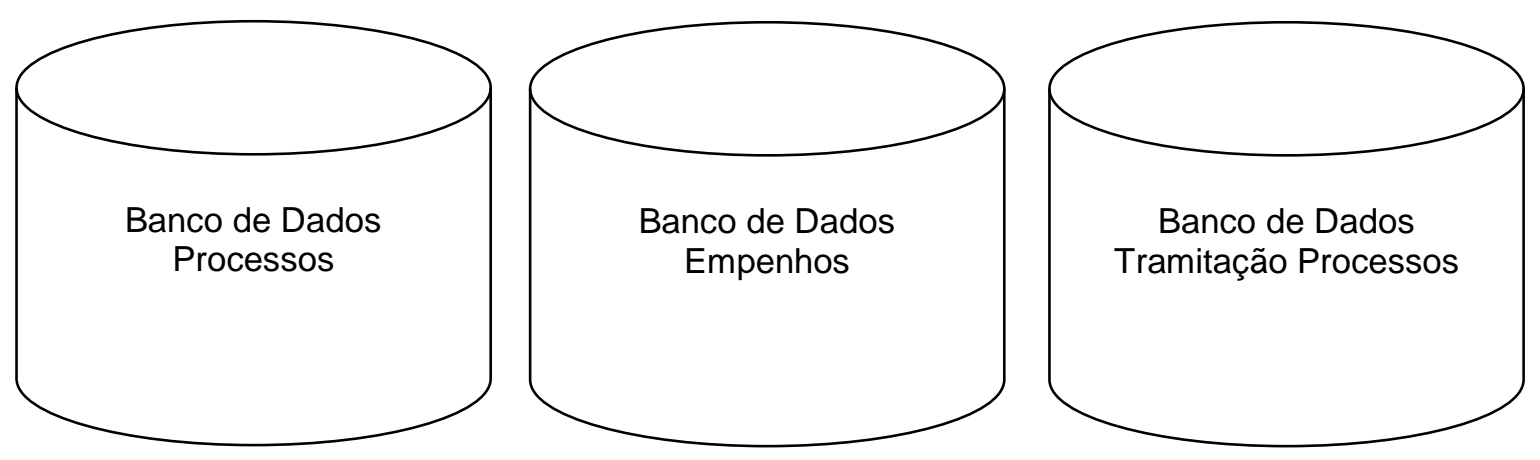

Fonte: Elaborado pelo autor, 2017.

\subsubsection{Processos Administrativos}

Quadro 25 - Quantidade de Processos Administrativos

\begin{tabular}{|c|c|c|c|c|}
\hline Descrição & 2013 & 2014 & 2015 & Total \\
\hline Qtde. Processos & 90 & 81 & 50 & 221 \\
\hline
\end{tabular}

Fonte: Dados da Pesquisa, 2017.

Verifica-se uma queda em relação à quantidade de Processos Administrativos abertos pelo DELOG para aquisição de medicamentos. De 2013 a 2015 houve uma redução de 44\% na quantidade de Processos Administrativos abertos. 
4.2.3 Estimativa de Custos com os Processos Administrativos

Quadro 26 - Estimativa de Custos com Processos Administrativos

\begin{tabular}{|c|c|c|c|c|}
\hline Descrição & $\mathbf{2 0 1 3}$ & $\mathbf{2 0 1 4}$ & $\mathbf{2 0 1 5}$ & Total \\
\hline Qtde. Processos & 90 & 81 & 50 & 221 \\
\hline $\begin{array}{c}\text { Estimativa de Custo } \\
\text { com Processos }\end{array}$ & $\mathrm{R} \$ 39.985,20$ & $\mathrm{R} \$ 35.986,68$ & $\mathrm{R} \$ 22.214,00$ & $\mathrm{R} \$ 98.185,88$ \\
\hline
\end{tabular}

Fonte: Dados da Pesquisa, 2017.

Tridapalli e Ferrer (2006), estudando a Gestão da Cadeia de Suprimentos do Governo do Estado do Amazonas, sugerem o custo unitário de $R \$ 234,91$ por Processo de aquisição. Não há estudos disponíveis sobre o custo unitário de um Processo Administrativo pra aquisição de bens e serviços no âmbito da Prefeitura Municipal de Manaus e nem esta pesquisa teve esta finalidade.

Entretanto, para efeito de estimativa de custo dos Processos de Aquisição de medicamento nesta pesquisa, utilizou-se como referência o valor do custo unitário proposto por Tridapalli e Ferrer (2006) de $\mathrm{R} \$ 234,91$, corrigido pelo Índice Geral de Preços do Mercado (IGPM) de 2007 a 2016, chegando ao montante de $\mathrm{R} \$ 444,28^{30}$.

Nesta direção, verifica-se que quanto maior a quantidade de Processos Administrativos para aquisição de medicamentos, maior será o custo para o Poder Público. O inverso também é verdadeiro. Diminuindo a quantidade de Processos Administrativos os custos serão menores. Logo, o ideal é racionalizar ao máximo a Gestão da Cadeia para ter o mínimo possível de Processos Administrativos.

\footnotetext{
${ }^{29}$ Calculo: [Qtde. Processos] x [R\$ 444,28]

${ }^{30}$ A atualização monetária foi necessário devido o tempo entre a publicação do Artigo de Tridapalli e Ferrer (2006) e a conclusão desta pesquisa. Para o calculo usou-se a ferramenta Calculo Exato (disponível em <http:// http://calculoexato.com.br >), no período de 01/01/2007 a 31/12/2016, usando o IGPM como índice.
} 


\subsubsection{Empenhos}

Quadro 27 - Quantidade de Empenhos

\begin{tabular}{|c|c|c|c|c|}
\hline Descrição & $\mathbf{2 0 1 3}$ & $\mathbf{2 0 1 4}$ & $\mathbf{2 0 1 5}$ & Total \\
\hline $\begin{array}{c}\text { Qtde. } \\
\text { Processos }\end{array}$ & 90 & 81 & 50 & 221 \\
\hline $\begin{array}{c}\text { Qtde. } \\
\text { Empenhos }\end{array}$ & 94 & 91 & 58 & 243 \\
\hline $\begin{array}{c}\text { Valor Total } \\
\text { Empenhos }\end{array}$ & $\mathrm{R} \$ 11.704 .321,86$ & $\mathrm{R} \$ 15.146 .675,50$ & $\mathrm{R} \$ 11.711 .910,20$ & $\mathrm{R} \$ 38.562 .907,56$ \\
\hline
\end{tabular}

Fonte: Dados da Pesquisa, 2017.

A análise dos Empenhos indica uma racionalização da abertura de Processos Administrativos, não implicando na diminuição do volume da aquisição. Verifica-se que em 2015 apenas 50 Processos Administrativos foram abertos, com um valor total de Empenhos maior que em 2013 quando foram abertos 90 Processos Administrativos. O destaque permeia o fato da redução do valor total dos Empenhos da ordem de $22,7 \%$ de 2014 para 2015.

Existe inda outra questão que permeia os Empenhos gerados pelos Processos de Aquisição, são os Empenhos que são recebidos pelos Fornecedores mas que nenhuma caixa de medicamento é entregue ao DELOG.

A pesquisa indica que em 2013 três Empenhos no valor total de $R \$ 39.618,00$ e em 2014 sete Empenho no valor de $\mathrm{R} \$ 177.727,50$ tiveram suas entregas zeradas. 
Quadro 28 - Empenhos Válidos

\begin{tabular}{|c|c|c|c|c|}
\hline Descrição & 2013 & 2014 & 2015 & Total \\
\hline Qtde. Processos & 90 & 81 & 50 & 221 \\
\hline Qtde. Empenhos & 94 & 91 & 58 & 243 \\
\hline Valor Total Empenhos & $\begin{array}{c}\mathrm{R} \$ \\
11.704 .321,86\end{array}$ & $\begin{array}{c}\mathrm{R} \$ \\
15.146 .675,50\end{array}$ & $\begin{array}{c}\mathrm{R} \$ \\
11.711 .910,20\end{array}$ & $\begin{array}{c}\mathrm{R} \$ \\
38.562 .907,56\end{array}$ \\
\hline $\begin{array}{c}\text { Qtde. Empenhos } \\
\text { Fornecedores não } \\
\text { Fizeram Nenhuma } \\
\text { Entrega } \\
\end{array}$ & 3 & 7 & 0 & 10 \\
\hline $\begin{array}{l}\text { Valor Total Empenhos } \\
\text { Sem Entregas }\end{array}$ & $\mathrm{R} \$ 39.618,00$ & $\mathrm{R} \$ 177.727,50$ & - & $\mathrm{R} \$ 217.345,50$ \\
\hline $\begin{array}{c}\text { \% Sobre o Valor Total } \\
\text { de Empenhos }{ }^{31}\end{array}$ & $0,34 \%$ & $1,17 \%$ & - & $0,56 \%$ \\
\hline $\begin{array}{l}\text { Qtde Empenhos } \\
\text { Validos }{ }^{32}\end{array}$ & 91 & 84 & 58 & 233 \\
\hline $\begin{array}{c}\text { Valor Total Empenhos } \\
\text { Validos }\end{array}$ & $\begin{array}{c}\mathrm{R} \$ \\
11.664 .703,86\end{array}$ & $\begin{array}{c}\mathrm{R} \$ \\
14.968 .948,00\end{array}$ & $\begin{array}{c}\mathrm{R} \$ \\
11.711 .910,20\end{array}$ & $\begin{array}{c}\mathrm{R} \$ \\
38.345 .562,06\end{array}$ \\
\hline
\end{tabular}

Fonte: Dados da Pesquisa, 2017.

Para fins de análise dos demais dados da pesquisa, serão observados apenas os Empenhos válidos, ou seja, Empenhos cujos Fornecedores realizaram entregas no DELOG.

${ }^{31}$ Calculo: ([100] x [Valor Total Empenhos Sem Entregas]) / [Valor Total Empenhos]

${ }^{32}$ Calculo: [Qtde. Empenhos] - [Qtde. Empenhos Fornecedores não Fizeram Nenhuma Entrega] 
4.2.5 Dotação Orçamentária x Valor Empenho

Quadro 29 - Dotação Orçamentária x Valor Empenho

\begin{tabular}{|c|c|c|c|c|}
\hline Descrição & $\mathbf{2 0 1 3}$ & $\mathbf{2 0 1 4}$ & $\mathbf{2 0 1 5}$ & Total \\
\hline Qtde. Processos & 90 & 81 & 50 & 221 \\
\hline Qtde. Empenhos & 94 & 91 & 58 & 243 \\
\hline Valor Total Empenhos & $\begin{array}{c}\mathrm{R} \$ \\
11.704 .321,86\end{array}$ & $\begin{array}{c}\mathrm{R} \$ \\
15.146 .675,50\end{array}$ & $\begin{array}{c}\mathrm{R} \$ \\
11.711 .910,20\end{array}$ & $\begin{array}{c}\mathrm{R} \$ \\
38.562 .907,56\end{array}$ \\
\hline $\begin{array}{c}\text { Dotação Orçamentária } \\
\text { Assistência Farmacêutica }\end{array}$ & $\begin{array}{c}\mathrm{R} \$ \\
20.462 .649,73\end{array}$ & $\begin{array}{c}\mathrm{R} \$ \\
19.168 .147,20\end{array}$ & $\begin{array}{c}\mathrm{R} \$ \\
32.674 .397,56\end{array}$ & $\begin{array}{c}\mathrm{R} \$ \\
72.305 .194,49\end{array}$ \\
\hline $\begin{array}{c}\text { \% Empenhado do Valor } \\
\text { Disponível para a } \\
\text { Assistência Farmacêutica }\end{array}$ & $57,20 \%$ & $79,02 \%$ & $35,84 \%$ & \begin{tabular}{c}
$53,33 \%$ \\
\hline
\end{tabular} \\
\hline
\end{tabular}

Fonte: Dados da Pesquisa, 2017.

Como mencionado anteriormente a Dotação Orçamentária para a Assistência Farmacêutica é prioritariamente usada para aquisição de medicamentos e insumos para saúde, mas não essencialmente.

Verifica-se que no ano de 2015, onde apenas $35,84 \%$ do valor da Dotação Orçamentária foram Empenhados para aquisição de medicamentos através de Ata de Registro de Preço.

\subsubsection{Tempo Autorização para Processar}

Quadro 30 - Tempo Médio Autorização para Processar

\begin{tabular}{|c|c|c|c|c|}
\hline Descrição & $\mathbf{2 0 1 3}$ & $\mathbf{2 0 1 4}$ & $\mathbf{2 0 1 5}$ & Total \\
\hline $\begin{array}{c}\text { Tempo Médio que o Memorando } \\
\text { Aguarda Autorização } \\
\text { para Processar } \\
(\mathrm{em} \mathrm{dias)})\end{array}$ & 2,8 & 6,7 & 4,9 & 4,7 \\
\hline
\end{tabular}

Fonte: Dados da Pesquisa, 2017.

\footnotetext{
${ }^{33}$ Calculo: ([100] x [Valor Total Empenhos]) / [Dotação Orçamentária Assistência Farmacêutica]

${ }^{34}$ Calculo: Média aritmética do Produto entre a [Data de Formalização no PROTUS] - [Data do Memorando]
} 
Após a Divisão de Medicamentos/DELOG elaborar o Memorando de aquisição de medicamentos, o mesmo vai para a Subsecretaria de Gestão Administrativa e Planejamento (SUBGAP) autorizar a formalização do Processo Administrativo junto ao PROTUS.

Verifica-se que no ano de 2014 onde o Memorando aguardou quase uma semana para ser autorizado seu processamento. Em 2015 houve uma ligeira queda em relação a 2014, mas ainda assim com uma média de tempo relativamente alta de 4,9 dias.

\subsubsection{Tempo PROTUS até Nota de Empenho}

Quadro 31 - Tempo Médio PROTUS até Nota de Empenho

\begin{tabular}{|c|c|c|c|c|}
\hline Descrição & $\mathbf{2 0 1 3}$ & $\mathbf{2 0 1 4}$ & $\mathbf{2 0 1 5}$ & Total \\
\hline $\begin{array}{c}\text { Tempo Médio PROTUS até } \\
\text { Emissão Nota de Empenho } \\
\text { (em dias) } \text { s5 }^{35}\end{array}$ & 20,3 & 30,7 & 40 & 31,6 \\
\hline
\end{tabular}

Fonte: Dados da Pesquisa, 2017.

Um dado relevante da pesquisa é o tempo de emissão da Nota de Empenho após a formalização do Processo Administrativo junto ao PROTUS. É relevante pois mostra a capacidade operacional dos Departamentos/Setores internos da SEMSA em agilizar o Processo Administrativo, ou seja, quando mais rápido a Nota de Empenho é emitida, maior a operacionalização interna.

Os dados indicam que no ano de 2013, em média a Nota de Empenho era emitida com 20,3 dias. Ao longo de 2014 e 2015 houve uma piora neste dado, chegando à média de 40 dias em 2015, praticamente o dobro de 2013.

Fazendo uma análise mais focada nos 50 Processos Administrativos no ano de 2015, verifica-se um fato que pode explicar o motivo deste tempo ser tão elevado: falta de padrão do fluxo de tramitação de Processos Administrativos para aquisição. Conforme o Quadro 31, houve ao menos 5 diferentes Fluxos na tramitação dos Processos Administrativos ao longo de 2015.

\footnotetext{
${ }^{35}$ Calculo: Média aritmética do Produto entre [Data de Emissão do Empenho] - [Data de Formalização no PROTUS] Obs: não foram computador registros onde a (1) Data da Emissão do Empenho inferior da Data de Formalização no PROTUS e (2) Data de Emissão do Empenho menor igual a 14 dias após a Data de Formalização no PROTUS.
} 
Quadro 32 - Exemplos de Diferentes Fluxos de Tramitação de Processos de Aquisição de Medicamentos - 2015

\begin{tabular}{|c|c|c|c|c|c|c|c|c|c|c|c|}
\hline & $\mathbf{1}$ & $\mathbf{2}$ & $\mathbf{3}$ & $\mathbf{4}$ & $\mathbf{5}$ & $\mathbf{6}$ & $\mathbf{7}$ & $\mathbf{8}$ & $\mathbf{9}$ & $\mathbf{1 0}$ & $\mathbf{1 1}$ \\
\hline A & SEPRO & DEADM & GEREP & DPLAN & GEXOR & GEREP & SEPRO & DELOG & & & \\
\hline B & SEPRO & DEADM & GEREP & DPLAN & DFMS & CGOF & DFMS & GEXOR & GEREP & SEPRO & DELOG \\
\hline C & SEPRO & DEADM & GEREP & DPLAN & CGOF & DPLAN & GEXOR & GEREP & SEPRO & DELOG & \\
\hline D & SEPRO & GEREP & DFMS & CGOF & DFMS & GEXOR & DICSO & SEPRO & DELOG & & \\
\hline E & SEPRO & GEREP & DFMS & GEXOR & DICSO & SEPRO & DELOG & & & & \\
\hline
\end{tabular}

Fonte: PROTUS.

Outro dado importante, reside no fato de que a partir de meados de 2015, por determinação da Prefeitura Municipal de Manaus, todos os Processos Administrativos de aquisição de bens ou serviços passaram obrigatoriamente pela Comissão de Gestão Orçamentária e Financeira (CGOF) que fica nas Dependências da Secretaria Municipal de Finanças (SEMEF), ou seja, o Processo Administrativo precisou sair fisicamente das dependências da SEMSA e isso aumentou o tempo de tramitação do Processo.

\subsubsection{Tempo Nota de Empenho até Fornecedor Receber Empenho}

Quadro 33 - Tempo Médio PROTUS até Nota de Empenho

\begin{tabular}{|c|c|c|c|c|}
\hline Descrição & $\mathbf{2 0 1 3}$ & $\mathbf{2 0 1 4}$ & $\mathbf{2 0 1 5}$ & Total \\
\hline $\begin{array}{c}\text { Tempo Médio Emissão Nota de } \\
\text { Empenhos até Fornecedor } \\
\begin{array}{c}\text { Receber Empenho } \\
\text { (em dias) }\end{array}\end{array}$ & 16,8 & 32,3 & 20,1 & 23,4 \\
\hline
\end{tabular}

Fonte: Dados da Pesquisa, 2017.

A Lei de licitações não estabelece o prazo para o Fornecedor retirar a Nota de Empenho (BRASIL, 1993) ficando a critério do Edital de Licitação, que, regularmente estabelece um prazo de cinco (5) dias.

Este ato é importante, pois a partir da ciência do Fornecedor da emissão da Nota de Empenho pelo Poder Público, o mesmo tem trinta dias para concluir o fornecimento dos itens descritos no Empenho. Logo, quanto mais tempo o

\footnotetext{
${ }^{36}$ Calculo: Média aritmética do Produto entre [Data Fornecedor Recebe Empenho] - [Data de Emissão do Empenho] Obs: não foram computador registros onde a (1) Data da Emissão do Empenho inferior da Data de Formalização no PROTUS e (2) Data de Emissão do Empenho menor igual a 14 dias após a Data de Formalização no PROTUS.
} 
Fornecedor demorar em retirar e dar ciência, mais tempo terá para entregar o material.

Dados da pesquisa indicam que nos anos de 2013 a 2015 a média de dias para retirar o Empenho tem sido bem superior a cinco dias. No ano de 2014 a média foi de 32,3 dias, ou seja, mais de um mês.

\subsubsection{Tempo Fornecedor Entregar Medicamento}

Quadro 34 - Tempo Médio Fornecedor Entregar Medicamentos

\begin{tabular}{|c|c|c|c|c|}
\hline Descrição & $\mathbf{2 0 1 3}$ & $\mathbf{2 0 1 4}$ & $\mathbf{2 0 1 5}$ & Total \\
\hline $\begin{array}{c}\text { Tempo Médio Fornecedor Receber } \\
\text { Empenho até Primeira Entrega } \\
\text { (em dias) }\end{array}$ & 30,9 & 26,6 & 40,8 & 31,8 \\
\hline $\begin{array}{c}\text { Tempo Médio Fornecedor Receber } \\
\text { Empenho até Ultima Entrega } \\
\text { (em dias) }\end{array}$ & 118,5 & 93,5 & 72,7 & 98,1 \\
\hline $\begin{array}{c}\text { Frequência de Entregas de } \\
\text { Medicamentos } \\
\text { (em Qtde.) }^{39}\end{array}$ & 3,3 & 3,4 & 2,9 & 3,5 \\
\hline
\end{tabular}

Fonte: Dados da Pesquisa, 2017.

O produto final de um processo de Aquisição de Medicamentos é a entrega dos medicamentos por parte do Fornecedor ao Departamento de Logística. Com mencionado, o Fornecedor tem trinta dias após o recebimento da Nota de Empenho para a entrega total de todos os itens e suas quantidades.

Entretanto, os dados da pesquisa demonstram um grande lead time entre 0 recebimento da Nota de Empenho e a entrega dos medicamentos. Em 2013 em média foram 30,9 dias para o Fornecedor fazer a primeira entrega de medicamentos. O dado se agrava em 2015, com uma média de 40,8 dias.

Já o tempo para entregar totalmente o Empenho era em média de 118,5 dia após recebimento do Empenho no ano de 2013. Este número vem caindo ao longo dos anos, mas ainda tem um longo lead time. Em 2015, por exemplo, a pesquisa indica uma média de 72,7 dias para concluir a entrega de um Empenho.

\footnotetext{
${ }^{37}$ Calculo: Média aritmética do Produto entre [Data Primeira Entrega Medicamento] - [Data Fornecedor Recebe Empenho]

${ }^{38}$ Calculo: Média aritmética do Produto entre [Data Ultima Entrega Medicamento] - [Data Fornecedor Recebe Empenho]

${ }^{39}$ Calculo: Média aritmética da Contagem da [Data Entrega de Medicamentos]
} 
4.2.10 Dotação Orçamentária x Empenhos x Valor Entregue

Quadro 35 - Dotação Orçamentária x Empenhos x Valor Entregue

\begin{tabular}{|c|c|c|c|c|}
\hline Descrição & 2013 & 2014 & 2015 & Total \\
\hline Qtde. Processos & 90 & 81 & 50 & 221 \\
\hline $\begin{array}{c}\text { Dotação Orçamentária } \\
\text { Assistência Farmacêutica }\end{array}$ & $\begin{array}{c}\mathrm{R} \$ \\
20.462 .649,73\end{array}$ & $\begin{array}{c}R \$ \\
19.168 .147,20\end{array}$ & $\begin{array}{c}\mathrm{R} \$ \\
32.674 .397,56\end{array}$ & $\begin{array}{c}\mathrm{R} \$ \\
72.305 .194,49\end{array}$ \\
\hline $\begin{array}{c}\text { Valor Total Empenhos } \\
\text { Validos }\end{array}$ & $\begin{array}{c}\mathrm{R} \$ \\
11.664 .703,86\end{array}$ & $\begin{array}{c}R \$ \\
14.968 .948,00\end{array}$ & $\begin{array}{c}R \$ \\
11.711 .910,20\end{array}$ & $\begin{array}{c}\mathrm{R} \$ \\
38.345 .562,06\end{array}$ \\
\hline $\begin{array}{c}\text { \% Valor Empenhos Válidos } \\
\text { sobre a Dotação } \\
\text { Orçamentária }{ }^{40}\end{array}$ & $57 \%$ & $78,09 \%$ & $35,84 \%$ & $53 \%$ \\
\hline $\begin{array}{c}\text { Valor Total de } \\
\text { Medicamentos Entregues } \\
\text { ao DELOG } 41\end{array}$ & $\begin{array}{c}\mathrm{R} \$ \\
10.723 .951,49\end{array}$ & $\begin{array}{c}R \$ \\
14.253 .650,17\end{array}$ & $\begin{array}{c}\mathrm{R} \$ \\
10.382 .169,66\end{array}$ & $\begin{array}{c}\mathrm{R} \$ \\
35.359 .771,32\end{array}$ \\
\hline $\begin{array}{c}\text { \% Valor Total de } \\
\text { Medicamentos entregue no } \\
\text { DELOG sobre o Valor } \\
\text { Total de Empenhos } \\
\text { Validos }\end{array}$ & $91,94 \%$ & $95,22 \%$ & $88,65 \%$ & $92,21 \%$ \\
\hline $\begin{array}{c}\text { \% Valor Total de } \\
\text { Medicamentos entregue no } \\
\text { DELOG sobre Dotação } \\
\text { Orçamentária }{ }^{42}\end{array}$ & $52,41 \%$ & $74,36 \%$ & $31,77 \%$ & $48,90 \%$ \\
\hline
\end{tabular}

Fonte: Dados da Pesquisa, 2017.

O Quadro 35 mostra um resumo geral ao longo dos anos 2013 a 2015 sobre a aquisição de medicamentos através de Ata de Registro de Preços. Pode-se destacar alguns dados relevantes.

Primeiro, o significativo aumento de recursos da Dotação Orçamentária para o ano de 2015, um incremento sobre 2014 da ordem de $70,46 \%$. Na contra mão deste aumento de recurso, está o valor da aquisição de medicamentos em 2015, representando apenas $35,84 \%$ sobre o valor da Dotação Orçamentária ${ }^{43}$.

Verifica-se que o produto final do ano de 2015 foi da ordem de $88,65 \%$, ou seja, dos $100 \%$ de itens de medicamentos solicitados para aquisição, apenas

\footnotetext{
${ }^{40}$ Calculo: ([Valor Total Empenhos Válidos] / [Dotação Orçamentária Assistência Farmacêutica]) x [100]

${ }^{41}$ Calculo: Soma do Valor Total de entradas dos Empenhos Válidos no DELOG

${ }^{42}$ Calculo: ([Valor Total Empenhos Entregues] / [Dotação Orçamentária Assistência Farmacêutica]) x [100]

${ }^{43}$ Contudo, não de pode concluir que apenas 35,84\% do valor da Dotação Orçamentária tenham sido gastas com medicamentos. Pode ser que outras modalidades de licitação tenham sido utilizadas para este fim. Somente aquisições através de Ata de Registro de Preços foram objeto de estudo desta pesquisa.
} 
$88,65 \%$ foi entregue ao DELOG, para a posteriori abastecer a Rede de Saúde da SEMSA, representando apenas $31,77 \%$ da Dotação Orçamentária para a Assistência Farmacêutica. 


\subsection{FLUXO OPERACIONAL DA GESTÃO DA CADEIA DE SUPRIMENTOS DE MEDICAMENTOS.}

\section{Quadro 36 - Fluxo Operacional da Cadeia de Suprimentos de Medicamentos}

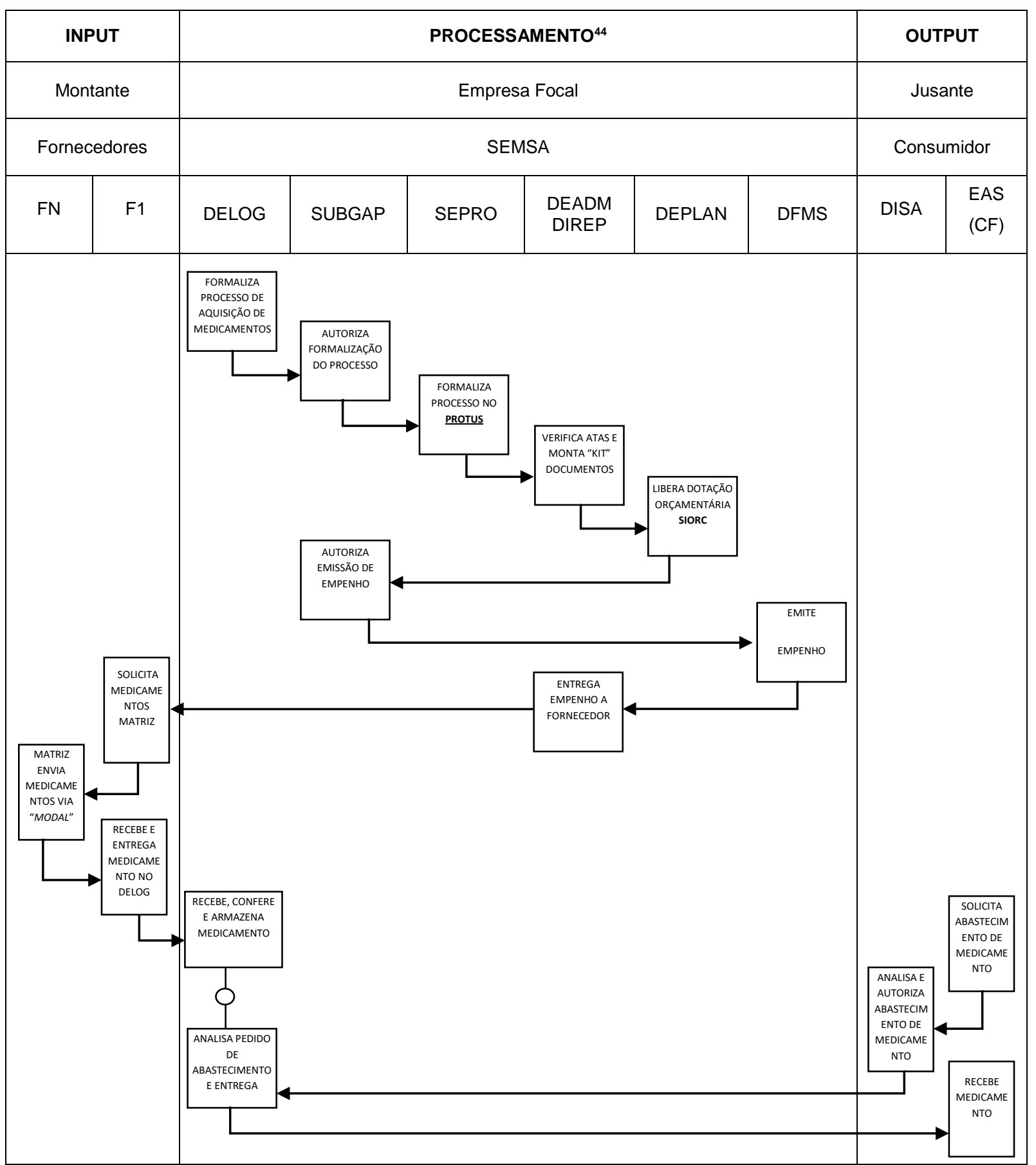

Fonte: Elaborado pelo Autor, 2017.

${ }^{44}$ A pesquisa indicou que ao longo dos anos de 2013 a 2015 não há um padrão no Fluxo Operacional interno da SEMSA, sendo estes os Departamentos/Setores basilares que aparecem em todos os Fluxos. A partir de meados de 2015 os Processos de Aquisição passaram a transitar na Comissão de Gestão Orçamentária e Financeira (CGOF) da Secretaria Municipal de Finanças (SEMEF). Mas como o CGOF não representa a totalidade macro da pesquisa ao longo de 2013 a 2015 o mesmo não foi incluso no Fluxo Operacional. 
A aquisição de medicamentos tem seu ambiente nascedouro no Departamento de Logística - DELOG.

A Divisão de Medicamentos e Insumos - DIMED procede à análise nos dados do Sistema de Estoque a fim de mensurar o consumo médio mensal de medicamentos, cruzando com a quantidade de medicamentos em estoque. A partir destes dados, é feito uma projeção estatística para abastecimento de medicamentos para os próximos " $n$ " meses 45 .

O Departamento elabora o Memorando de aquisição de medicamento. Este Memorando é protocolizado na Subsecretaria de Gestão Administrativa e Planejamento (Autorizador de Despesas) que dá sua chancela autorizando ou não a formalização de Processo Administrativo para aquisição de medicamentos.

Se autorizado, o Memorando é encaminhado para o Setor de Protocolo (SEPRO), onde será formalmente aberto o Processo Administrativo para Aquisição de Medicamentos no Sistema de Protocolo (PROTUS). Uma vez registrado no PROTUS, o Processo Administrativo ganha um número de identificação composto por 12 dígitos numéricos, sendo, quatro dígitos o ano, quatro dígitos o número de identificação da Secretaria e quatro dígitos um número sequencial gerado pelo PROTUS, por exemplo:

\section{Quadro 37 - Identificação do Processo Administrativo}

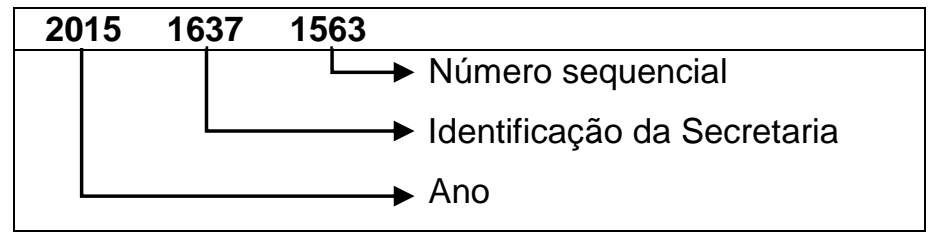

Fonte: Elaborado pelo Autor, 2017.

Este número de identificação do Processo Administrativo, ou simplesmente, número do processo, é o "nome" do Processo Administrativo dentro da Administração Pública Municipal, ele é único, imutável, intransferível e inviolável. Nenhuma outra Secretaria ou Repartição terá um número igual de processo no Município. Ele servirá para acompanhar toda a tramitação do processo, bem como para futuras consultas mesmo após seu arquivamento.

\footnotetext{
45 Não existe uma regra para este quantitativo " $n$ " de meses. Podendo ser 3,4 ou até mesmo 6 meses. Depende de uma série de fatores como: (1) orçamento; (2) período do ano; (3) outras demandas de saúde.
} 
Após o processo estar devidamente formalizado e identificado, inicia a tramitação propriamente dita dentro da Secretaria, passando por vários Setores.

Como se trata de Processo de Aquisição de Medicamentos através de Ata de Registro de Preços vigente na Secretaria Municipal de Saúde, o processo é encaminhado para a Divisão de Registro de Preços (DIREP).

No DIREP vários procedimentos internos são realizados: (1) Se há saldo em Ata; (2) Verifica-se a validade das Atas; (3) Se há erros na redação do Memorando concernente aos dados da Ata. Caso haja alguma inconformidade, o Processo Administrativo é encaminhado ao DELOG para correções. Estando tudo correto, o DIREP emite despacho favorável à aquisição de medicamentos e anexa o "kit" de documentos ao Processo Administrativo. O "kit" de documentos consiste em: (1) cópia da Ata de Registro de Preços devidamente homologada; (2) Certidão Negativa de Débitos do FGTS; (3) Certidão Negativa de Débitos do Município; (3) Certidão Negativa de Débitos da Receita Federal; (4) Certidão Negativa de Débitos do Estado; (5) Certidão Negativa de Débitos do INSS. Após, o Processo Administrativo vai para o Departamento de Planejamento (DEPLAN).

No DEPLAN é feito a dotação orçamentária. A dotação orçamentária consiste em informar de onde sairá o recurso para custear a aquisição, para tanto, é utilizado o Sistema Orçamentário (SIORC) ${ }^{46}$ para definir: (1) Função; (2) Subfunção; (3) Programa; (4) Ação; (5) Natureza da Despesa; (6) Subitem de natureza da despesa; (7) Fonte e (8) Valor. Após, o Processo Administrativo segue para o Autorizador de Despesas, a Subsecretaria de Gestão Administrativa e Planejamento, para conhecimento e autorização.

Da Subsecretaria de Gestão Administrativa e Planejamento o Processo Administrativo vai para o Departamento do Fundo Municipal de Saúde, para ser empenhado ${ }^{47}$. A emissão da Nota de Empenho é um procedimento administrativo interno do Departamento, sendo feito no Sistema de Administração Financeira Integrada Municipal (AFIM). Neste Sistema são informados todos os itens que estão

\footnotetext{
${ }^{46}$ O SIOEC é um Sistema interno da SEMSA. Quando o exercício orçamentário inicia os valores publicados na Lei Orçamentária Anual (LOA) são lançados neste Sistema, da mesma forma que são lançados pela SEMEF no AFIM, que é um Sistema da Prefeitura. As informações nestes dois Sistemas precisam estar sempre iguais.

47 O empenho representa o primeiro estágio da despesa orçamentária. É registrado no momento da contratação do serviço, aquisição do material ou bem, obra e amortização da dívida. Segundo o art. 58 da Lei no 4.320/1964, empenho é o ato emanado de autoridade competente que cria para o Estado obrigação de pagamento pendente ou não de implemento de condição. Consiste na reserva de dotação orçamentária para um fim específico.
} 
sendo adquiridos através da Ata de Registro de Preços, bem como todas as informações da dotação orçamentária: (1) Função; (2) Subfunção; (3) Programa; (4) Ação; (5) Natureza da Despesa; (6) Subitem de natureza da despesa; (7) Fonte e (8) Valor. Uma vez emitida a Nota de Empenho, o recurso fica "congelado" para o pagamento da despesa. A Nota de Empenho é como se fosse um "cheque" da Administração Pública mostrando a disponibilidade em honrar o compromisso e pagar por aquela aquisição de medicamentos. A Nota de Empenho gera uma obrigação de pagar por parte da Administração Pública.

Assim como o Processo Administrativo, a Nota de Empenho também tem uma numeração própria com 11 dígitos alfanuméricos, sendo 4 dígitos numéricos indicando o ano, 2 dígitos a sigla "NE" e os últimos 5 dígitos um número sequencial gerado pelo AFIM, por exemplo:

Quadro 38 - Identificação do Empenho

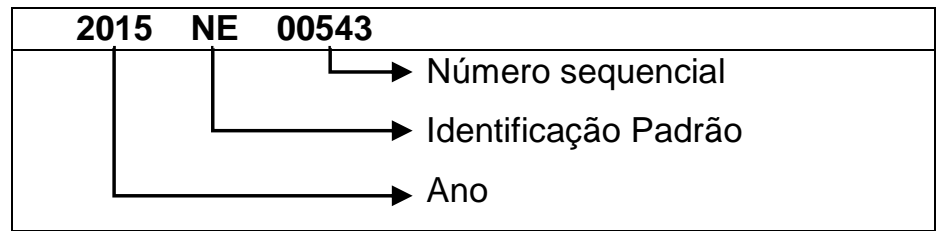

Fonte: Elaborado pelo Autor, 2017.

Existe outra peculiaridade na emissão da Nota de Empenho. Um Processo Administrativo de Aquisição de Medicamento pode ter " $y$ ” Notas de Empenho. Isto se dá devido à fonte de pagamento. Fontes de pagamento ${ }^{48}$ diferentes irão gerar Notas de Empenho diferentes não obstante serem do mesmo Processo Administrativo. Uma vez empenhado, o Processo Administrativo volta para o DIREP.

O DIREP tem a responsabilidade de convocar o Fornecedor para que este tome ciência que há uma demanda de aquisição de medicamentos. O Fornecedor vai ao DIREP e recebe a Nota de Empenho. Não há limite de tempo e nem obrigatoriedade para o Fornecedor receber a Nota de Empenho. Após ciência e recebimento da Nota de Empenho o Fornecedor tem trinta (30) dias para efetuar a entrega dos materiais descritos na Nota de Empenho junto ao Departamento de Logística.

\footnotetext{
48 Existem várias fontes orçamentárias que financiam a aquisição de medicamento, por exemplo: 01000000 Recursos Ordinários; 02140012 - Média e Alta Complexidade Ambulatorial e Hospitalar - TETO MAC; 02140015 - Assistência Farmacêutica Federal, etc.
} 
O Processo Administrativo segue para o DELOG. Este irá aguardar a entrega dos medicamentos na Central de Medicamentos ${ }^{49}$.

Concomitante, os Estabelecimentos Assistenciais de Saúde continuam tendo suas demandas de medicamentos. Diariamente milhares de usuários do SUS são atendidos nos Estabelecimentos Assistenciais de Saúde e como preceitua a legislação, estes usuários recebem gratuitamente os medicamentos. Para suprir tal demanda, os Estabelecimentos Assistenciais de Saúde solicitam abastecimento de medicamentos ao DELOG. Existe um cronograma preconizado pelo DELOG (ver Anexo 1 e Anexo 2) que estabelece os prazos para a logística de distribuição de medicamentos nos Estabelecimentos Assistenciais de Saúde.

Os servidores dos Estabelecimentos Assistenciais de Saúde preenchem o Mapa de Abastecimento de Medicamentos manualmente, baseando-se em dois critérios: (1) Estoque atual de medicamentos e (2) Padrão de Medicamentos ${ }^{50}$. Após, este Mapa de Abastecimento de Medicamentos é encaminhado para a Assistência Farmacêutica do Distrito de Saúde cujo EAS está vinculado.

Na Assistência Farmacêutica do Distrito de Saúde os Técnicos Farmacêuticos farão uma análise no pedido do Estabelecimento Assistencial de Saúde a fim de verificar alguma inconsistência ou irregularidade. Caso haja alguma inconformidade o Mapa de Abastecimento de Medicamentos é devolvido para o EAS a fim de fazer as correções. Estando correto, a Assistência Farmacêutica faz a juntada com todos os Mapas de Abastecimento de Medicamentos de todos os Estabelecimentos Assistenciais de Saúde vinculados ao Distrito de Saúde e envia para o Departamento de Logística.

No Departamento de Logística o Mapa de Abastecimento de Medicamentos deve ser entregue dentro do prazo estipulado no cronograma. A Divisão de Medicamentos faz uma nova análise nos Mapa de Abastecimento de Medicamentos procurando inconsistências ou irregularidades. Caso alguma seja encontrada, o

\footnotetext{
${ }^{49}$ Galpão onde ficam armazenados os medicamentos, demais materiais e insumos de saúde.

${ }^{50}$ Cada Estabelecimento Assistencial de Saúde tem um Padrão de Medicamentos de acordo com sua Tipologia. Este Padrão de Medicamentos consiste numa Lista com QUAIS e QUANTOS medicamentos fazem parte do portfólio do Estabelecimento Assistencial de Saúde. Isso independe da quantidade de usuários que são atendidos. O critério é baseado na capacidade instalada. Por exemplo: Uma UBSF (mais conhecida como casinha) tem uma Lista com " $n$ " medicamentos e para cada medicamento há uma quantidade de " $X$ " unidades deste medicamento. Outro exemplo: Na UBSF não contem antibióticos no seu Padrão de Medicamentos, pois na UBSF não tem o Profissional Farmacêutico (a legislação preconiza a presença de um Farmacêutico para que haja distribuição ou comercialização de antibióticos). A Assistência Farmacêutica da SEMSA é responsável por definir o Padrão de Medicamentos para cada Tipologia.
} 
Mapa de Abastecimento de Medicamentos é devolvido para a Assistência Farmacêutica do Distrito de Saúde, que devolve para o Estabelecimento Assistencial de Saúde. Estando correto é encaminhado para a Divisão de Almoxarifado, responsável pela Logística Interna e Logística de Distribuição dos Medicamentos.

A Divisão de Medicamentos (1) verifica o estoque, (2) lança a saída no Sistema de Estoque, (3) separa os medicamentos e (4) envia os medicamentos no modal terrestre para o Estabelecimento Assistencial de Saúde conforme o cronograma.

O usuário do SUS é o cliente final nesta Cadeia de Suprimentos. É ele quem irá receber o medicamento receitado pelo médico da Unidade de Saúde. Toda Gestão da Cadeia de Medicamentos, deste o Memorando de Aquisição de Medicamento feito pelo DELOG tem esta finalidade: atender aos usuários do SUS da Rede de Saúde do Município.

\subsection{SUGESTÕES DE MELHORIAS NA GESTÃO DA CADEIA DE SUPRIMENTOS:} A JUSANTE

A aquisição de medicamentos (logística de suprimentos) está simbioticamente relacionada à distribuição de medicamentos aos usuários do SUS (logística de distribuição), pois não são ações isoladas e independentes, são ações em cadeia, e se um elo da cadeia estiver comprometido ou com um processo de trabalho desajustado, isso afetará a toda a Gestão da Cadeia de Suprimentos.

Não adiantará ter um modelo de aquisição de medicamentos (input) se o final da Cadeia, que é a entrega do medicamento ao usuário do SUS (output) não for bem gerenciada, por isso a necessidade dentro desta pesquisa de apresentar sugestões de melhorias no Processo de Distribuição de Medicamentos.

Ao longo do ano de 2015 alguns Estabelecimentos Assistenciais de Saúde do Distrito de Saúde Sul ${ }^{51}$ foram escolhidos aleatoriamente a fim de coletar dados, verificar in loco o processo de trabalho, e fazer observações, conforme Metodologia para o Estudo de Caso.

\footnotetext{
${ }^{51}$ Critérios para escolha do Distrito de Saúde Sul: (1) tem a maior rede de Unidades de Saúde vinculadas ao Distrito; (2) os processos de trabalho são padronizados para todas as Unidades de Saúde, logo, as Unidades do Disa Sul refletem a realidade da Rede de Saúde da SEMSA Manaus.
} 
Segue-se uma descrição do processo de logística de distribuição de medicamentos da SEMSA, a fim de subsidiar as sugestões que serão apresentadas.

\subsubsection{Logística de Distribuição de Medicamentos.}

A distribuição de medicamentos (logística de distribuição) na Rede de Saúde da SEMSA é um elo da Cadeia de Suprimentos que exige grande esforço técnico e operacional do Departamento de Logística (DELOG), mobilizando dezenas de servidores, pessoal terceirizado e transporte no modal terrestre a fim de que o medicamento certo chegue na quantidade certa, a tempo abio, no destino correto.

Entretanto, a logística de distribuição não inicia quando o medicamento é colocado dentro do caminhão para entrega, mas quando o Estabelecimento Assistencial de Saúde solicita o abastecimento de medicamento através do Mapa de Abastecimento de Medicamentos.

A gestão de medicamentos dentro do Estabelecimento Assistencial de Saúde é feito de forma manual, não existe um Sistema de Informação que faça o controle do estoque, controle de lotes, validade, consumo médio mensal, análise de demanda, dados estatísticos e emita relatórios com as necessidades de abastecimento de medicamento.

Como mencionado, os servidores dos Estabelecimentos Assistenciais de Saúde preenchem o Mapa de Abastecimento de Medicamentos manualmente, baseando-se em dois critérios: (1) Estoque atual de medicamentos e (2) Padrão de Medicamentos. Depois este Mapa é enviado por e-mail a Assistência Farmacêutica do Distrito de Saúde e posteriormente encaminhado fisicamente ao Departamento de Logística que fará o abastecimento.

O Mapa de Abastecimento de Medicamentos é o input deste Processo (logística de distribuição). Um Mapa de Abastecimento de Medicamentos incorreto, com falhas ou inconsistências acarretará em falta ou excesso de medicamentos na Unidade de Saúde. A falta de medicamentos causará a interrupção no tratamento de saúde dos usuários do SUS e o excesso de medicamento pode levar a perdas. Por isso este input inicial é extremamente importante na Logística de Distribuição.

Verifica-se que é um ponto crítico na Logística de Distribuição de Medicamentos, pois é um processo de trabalho manual, burocrático e com um lead time longo entre o pedido e a entrega dos medicamentos. 
Tratando-se de abastecimento de medicamentos, um lead time de 7 dias úteis faz uma grande diferença pois quando da solicitação de medicamentos através do Mapa de Abastecimento de Medicamento este lead time não é estatisticamente calculado, acarretando um efeito chicote a jusante, no consumidor final da cadeia, o usuário do SUS.

Um dos fatores que eleva o lead time do abastecimento é o fluxo operacional. O Mapa de Abastecimento é enviado pela Unidade de Saúde para a Assistência Farmacêutica do Distrito de Saúde.

A Assistência Farmacêutica faz uma análise do Mapa. Se houver alguma inconsistência o Mapa é devolvido para a Unidade de Saúde. Estando tudo coerente os Mapas de todos os Estabelecimentos de Saúde do Distrito de Saúde são juntados e encaminhados ao DELOG.

No DELOG os Mapas são novamente analisados pelos farmacêuticos da Divisão de Medicamentos e Insumos. Se houver alguma inconsistência o Mapa é devolvido para a Assistência Farmacêutica do Distrito de Saúde, que por sua vez devolve para a Unidade de Saúde fazer as correções. Após as correções, segue-se novamente o fluxo conforme citado acima.

Todo este processo é manual, depende de transporte ${ }^{52}$ para levar os Mapas de um local para o outro, burocrático e moroso.

Outro ponto a ser destacado na logística de distribuição e que afeta diretamente a logística de suprimentos é que a Gestão da SEMSA não tem nenhum controle sobre a distribuição dos medicamentos aos usuários do SUS. O controle limita-se do DELOG a Unidade de Saúde ${ }^{53}$. Da Unidade de Saúde ao usuário do SUS não há controles, pois não há Sistema de Informação. O único "controle" é a receita médica, entretanto a pesquisa de campo constatou que a mesma não tem utilidade.

O usuário do SUS (paciente) ao passar por uma consulta médica recebe a receita médica em duas vias ${ }^{54}$, sendo a primeira via do paciente e a segunda via da Farmácia. O usuário dirige-se a Farmácia da Unidade de Saúde a fim de retirar o(s)

\footnotetext{
${ }^{52}$ A questão do transporte é bem complexa. Nem sempre é possível disponibilizar transporte (carro ou moto) para executar uma tarefa de imediato. Em algumas situações a nova demanda precisa entrar na rotina do transporte, o que demanda tempo.

53 O DELOG tem um Sistema de Informação que faz a Gestão do Estoque de Medicamento e demais materiais.

${ }^{54}$ Este é um procedimento padrão nas Unidades de Saúde da Rede de Saúde da SEMSA.
} 
medicamento(s) prescrito(s). Na via do paciente o profissional de saúde "dá baixa"55 nos medicamentos que forem entregues ao paciente, a segunda via é retida na Farmácia.

Entretanto, a via da receita médica retida na Farmácia da Unidade de Saúde não tem utilidade, não é dada baixa no estoque, não é feito nenhum levantamento sobre as demandas de consumos, perfil epidemiológicos, consumo médio mensal, etc. As receitas médicas são descartadas.

Figura 17 - Arquivo de Receituário Médico de uma UBSF

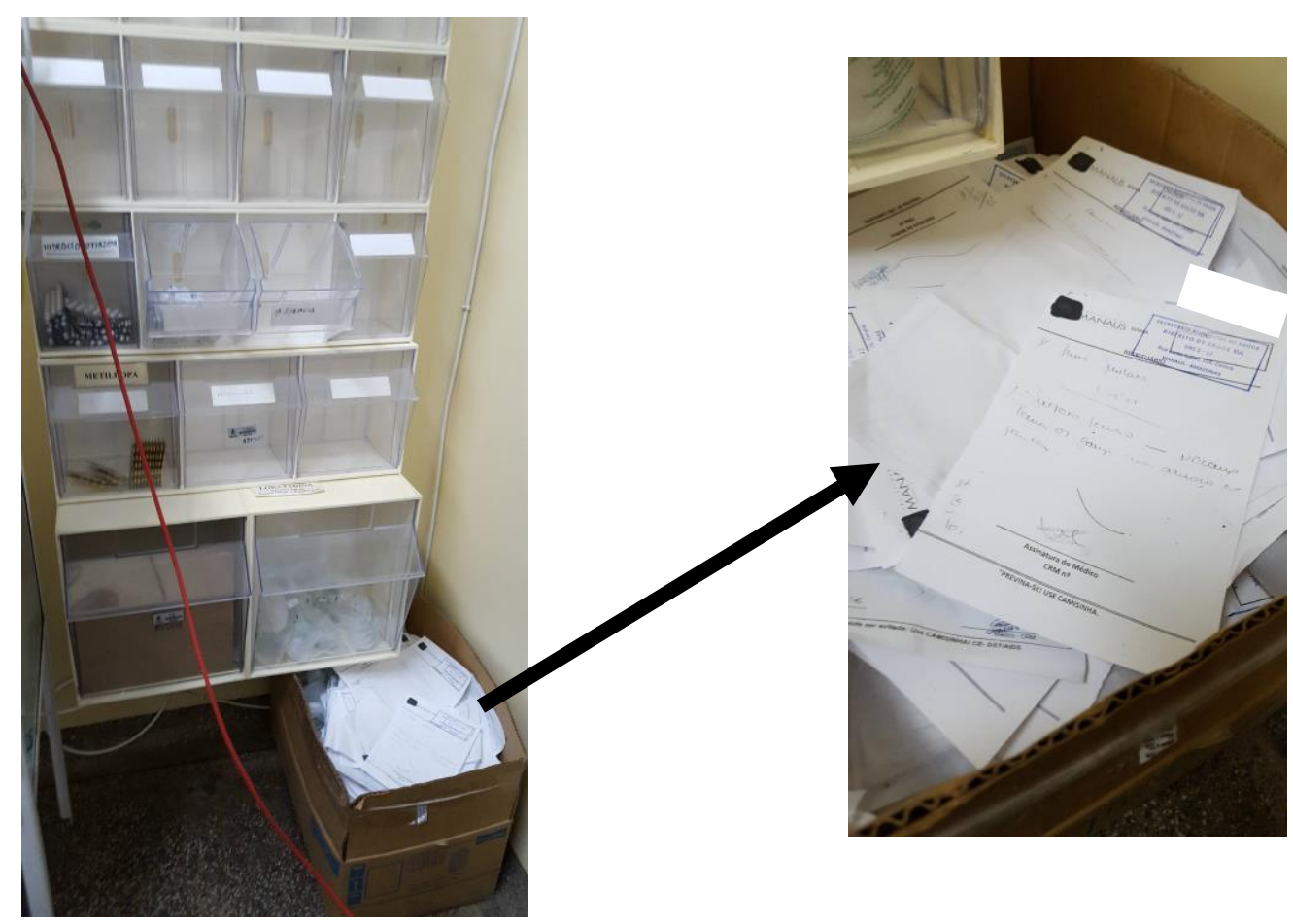

Fonte: Pesquisa de campo, 2017.

Neste modelo de trabalho, as receitas médicas retidas nas Unidades de Saúde estão sendo fonte de desperdício para os cofres públicos, pois conforme pesquisa de campo, as receitas são (1) arquivas e posteriormente descartadas pelas próprias Unidades de Saúde ou (2) enviadas ao Distrito de Saúde e posteriormente descartadas. Durante a pesquisa não foi possível mensurar a quantidade de receitas

\footnotetext{
${ }^{55} \mathrm{Em}$ algumas Unidades usa-se um carimbo "entregue", em outras apenas o profissional de saúde escreve a mão na receita "medicamento entregue". Isto é para evitar que o paciente peque o mesmo medicamento em outra Unidade de Saúde.
} 
médicas que são descartadas em todos os Estabelecimentos Assistenciais de Saúde e nem o custo para o erário do Município.

Entretanto, utilizando dados das consultas médicas de 2013 a 2015 e usando como referência uma Ata de Registro de $\operatorname{Preços}^{56}$ da SEMSA para aquisição de Receituário Médico, é possível presumir o custo com as receita médicas retidas nas Unidades de Saúde e posteriormente descartadas.

Quadro 39 - Presunção de Custos com Desperdício de Receituário Médico

\begin{tabular}{|l|r|r|r|}
\hline \multicolumn{1}{|c|}{ Descrição } & $\mathbf{2 0 1 3}$ & $\mathbf{2 0 1 4}$ & $\mathbf{2 0 1 5}$ \\
\hline Quantidade de Consultas Médicas $^{57}$ & 1.295 .816 & 1.070 .286 & 1.262 .644 \\
\hline Custo Com Receitas (2 Vias) ${ }^{58}$ & $\mathrm{R} \$ 168.456,08$ & $\mathrm{R} \$ 139.137,18$ & $\mathrm{R} \$ 164.143,72$ \\
\hline Custo Desperdício Receita & $\mathrm{R} \$ 84.228,04$ & $\mathrm{R} \$ 69.568,59$ & $\mathrm{R} \$ 82.071,86$ \\
\hline
\end{tabular}

Fonte: Elaborado pelo Autor, 2017.

Conforme Quadro 39, conjectura-se que a Administração Pública teve ao longo dos anos de 2013 a 2015 um custo de $\mathrm{R} \$ 235.868,49$ com receitas médicas retidas das Unidades de Saúde que são posteriormente descartadas.

Durante a pesquisa de campo, observou-se uma tendência dos usuários do SUS (pacientes) em fazerem estoque de medicamentos em suas residências devido ao medo da escassez ou falta de medicamentos na Unidade de Saúde para dar continuidade ao seu tratamento de saúde. Uma vez de posse da receita médica o usuário tira cópia da receita, retirando o medicamento em várias Unidades de Saúde. Como não existe um Sistema de Informação que identifique que àquele usuário já retirou o medicamento prescrito, o medicamento acaba sendo "liberado" novamente ao paciente ${ }^{59}$.

\footnotetext{
${ }^{56}$ Ata de Registro de Preços Publicada no Diário Oficial do Município n. 1509, de 26 de junho de 2006. Valor de R\$ 3,34 para um bloco com 100 (cem) folhas de Receituário Médico. Após atualização monetária deste valor pelo IGPM no período de 26/07/2006 a 31/12/2016 (fonte: http://calculoexato.com.br ) obteve-se o valor de $\mathrm{R} \$$ 6,47. Para chegar ao Valor Unitário da Receita Médica dividiu-se R\$ 6,47 por 100, chegando ao Valor Unitário de $\mathrm{R} \$ 0,065$ por folha de Receita Médica.

${ }^{57}$ Fonte: Departamento de Informação, Controle, Avaliação e Regulação (DICAR).

58 Para o calculo levou-se em consideração que cada consulta médica origina duas receitas médicas por paciente, para tanto, multiplicou-se a QTDE. DE CONSULTAS por 2 e posteriormente multiplicou-se pelo valor unitário da Receita Médica $\mathrm{R} \$ 0,033$.

59 Isto é algo que precisaria ser devidamente mensurado através de uma pesquisa científica. Mas dentro da observação neste Estudo de Caso, pôde-se contatar esta realidade. O recebimento de cópia da receita médica é
} 
Este é um procedimento que causa um grande problema para o input da Cadeia de Suprimentos de Medicamentos, pois, torna-se quase impossível mensurar com exatidão o output da cadeia.

4.4.2 Sugestões de Melhorias na Logística de Distribuição de Medicamentos.

Apresenta-se a seguir sugestões de melhorias no Processo de distribuição de medicamentos (output) a fim de balancear a Gestão da Cadeia de Suprimentos de Medicamentos.

4.4.2.1 Implantar um Sistema de Informação para a Gestão da Cadeia de Suprimentos

Um Sistema de Informação para a Gestão da Cadeia de Suprimentos de Medicamentos, especialmente nas Unidades de Saúde trará resultados significativos na Cadeia de Suprimentos. Tridapalli (2011) é tácito ao afirmar que a Tecnologia da Informação (TI) é um importante aliado na Gestão da Cadeia de Suprimentos, corroborando, Souza (2014) reitera que os Sistemas de Informação ajudam na redução de custos e aumento da eficiência.

Um Sistema de Informação via web, interligado com todas as Unidades de Saúde do Município ${ }^{60}$ e interligado ao Sistema de Estoque do DELOG. Um Sistema de Informação inteligente, onde a gestão do estoque de medicamentos dentro da Unidade de Saúde fosse automatizada, quando da necessidade de abastecimento de medicamento, o Sistema automaticamente informasse ao DELOG os medicamentos necessários e suas quantidades (conforme padrão e tipologia). Onde a dispensação de medicamentos aos usuários do SUS fosse identificada/registrada, evitando assim a possibilidade de retirada do mesmo medicamento em outras Unidades. Da mesma forma, quando não houvesse o medicamento na Unidade, o Sistema indicasse ao usuário do SUS qual Unidade de Saúde mais próxima tem o referido medicamento.

comum em algumas Unidades de Saúde, principalmente em tratamento de doenças como diabete e hipertensão, onde o paciente precisa ir mensalmente a Unidade retirar o medicamento para seu tratamento. 60 Praticamente todas as Unidades de Saúde do município têm acesso à internet. 
Outra vantagem com o Sistema de Informação para a Gestão de Medicamentos nas Unidades de Saúde seria melhor controle da validade dos medicamentos, evitando assim o desperdício do erário público. Uma Unidade de Saúde com alto estoque de um determinado medicamento poderia, através do Sistema, (re)distribuir o mesmo para outras Unidades. Outra economia seria com a utilização de apenas uma via da receita médica, sem a necessidade de deixar uma via da receita na Farmácia da Unidade, pois todo controle seria via Sistema.

Uma alternativa rápida, segura e sem custos para o Município, seria a utilização do Sistema Nacional de Gestão da Assistência Farmacêutica (HÓRUS), disponibilizado pelo Ministério da Saúde e em curso em alguns municípios do País.

Segundo o Portal da Saúde ${ }^{61}$ o HÓRUS foi desenvolvido para gestão dos medicamentos e insumos dos Componentes da Assistência Farmacêutica e do Subsistema de Atenção à Saúde Indígena (SASISUS). O sistema possui diversas características que garantem sua singularidade:

- Desenvolvido em plataforma web;

- Integrado ao Cadastro Nacional de Usuários (CadSUS Web);

- Integrado ao Cadastro Nacional de Estabelecimentos de Saúde (CNES);

- Cadastro de produtos centralizado e de acordo com o Catálogo de Materiais e Medicamentos do Governo Federal (CATMAT);

- Desenvolvido de acordo com as regras pautadas na legislação vigente;

- Parametrizado de acordo com as regras dos Protocolos Clínicos e Diretrizes Terapêuticas (PCDT) e da Tabela de Procedimentos, Medicamentos e OPM do SUS (SIGTAP);

- Perfil de acesso de acordo com as especificidades do fluxo de entrada, distribuição e dispensação de produtos nos serviços de saúde.

Ainda segundo o Portal da Saúde, o HÓRUS apresenta os seguintes benefícios:

- Identificação em tempo real dos estoques nos estabelecimentos de saúde que gerenciam medicamentos e insumos;

- Rastreabilidade dos produtos distribuídos e dispensados;

\footnotetext{
${ }^{61}$ Ministério da Saúde. Governo Federal. Disponível no site: < http://portalsaude.saude.gov.br/index.php/oministerio/principal/leia-mais-o-ministerio/1158-sctie-raiz/daf-raiz/ceaf-sctie/qualifarsus-raiz/horus/I1horus/horus-principal/18716-o-que-e-horus > Acessado em 22.12.2016
} 
- Controle e monitoramento dos recursos financeiros investidos na aquisição e distribuição dos medicamentos;

- Geração do arquivo de Autorizações de Procedimentos Ambulatoriais (APAC) para repasse de recursos financeiros;

- Geração dos livros de medicamentos sujeitos a controle especial;

- Agendamento das dispensações, identificação da demanda de atendimento e da origem das prescrições;

- Conhecimento do perfil de acesso e utilização de medicamentos e insumos nos serviços;

- Contribuição com a formação da Base Nacional de dados de ações e serviços da Assistência Farmacêutica no SUS, que auxilia o monitoramento e avaliação da assistência farmacêutica no país.

Um Sistema de Informação para a Gestão de Medicamentos nas Unidades de Saúde é conditio sine qua non para a Gestão da Cadeia de Suprimento de Medicamentos da Secretaria Municipal de Saúde de Manaus.

\subsubsection{Modificar o Fluxo Operacional de Abastecimento de Medicamento}

O Fluxo Operacional em vigor para o abastecimento de medicamentos dos Estabelecimentos Assistenciais de Saúde (EAS) é burocrático, não agrega valor e tem vários pontos de retrabalho, sendo um dos principais responsáveis pelo amplo lead time. 
Quadro 39 - Fluxo Operacional Abastecimento de Medicamentos EAS

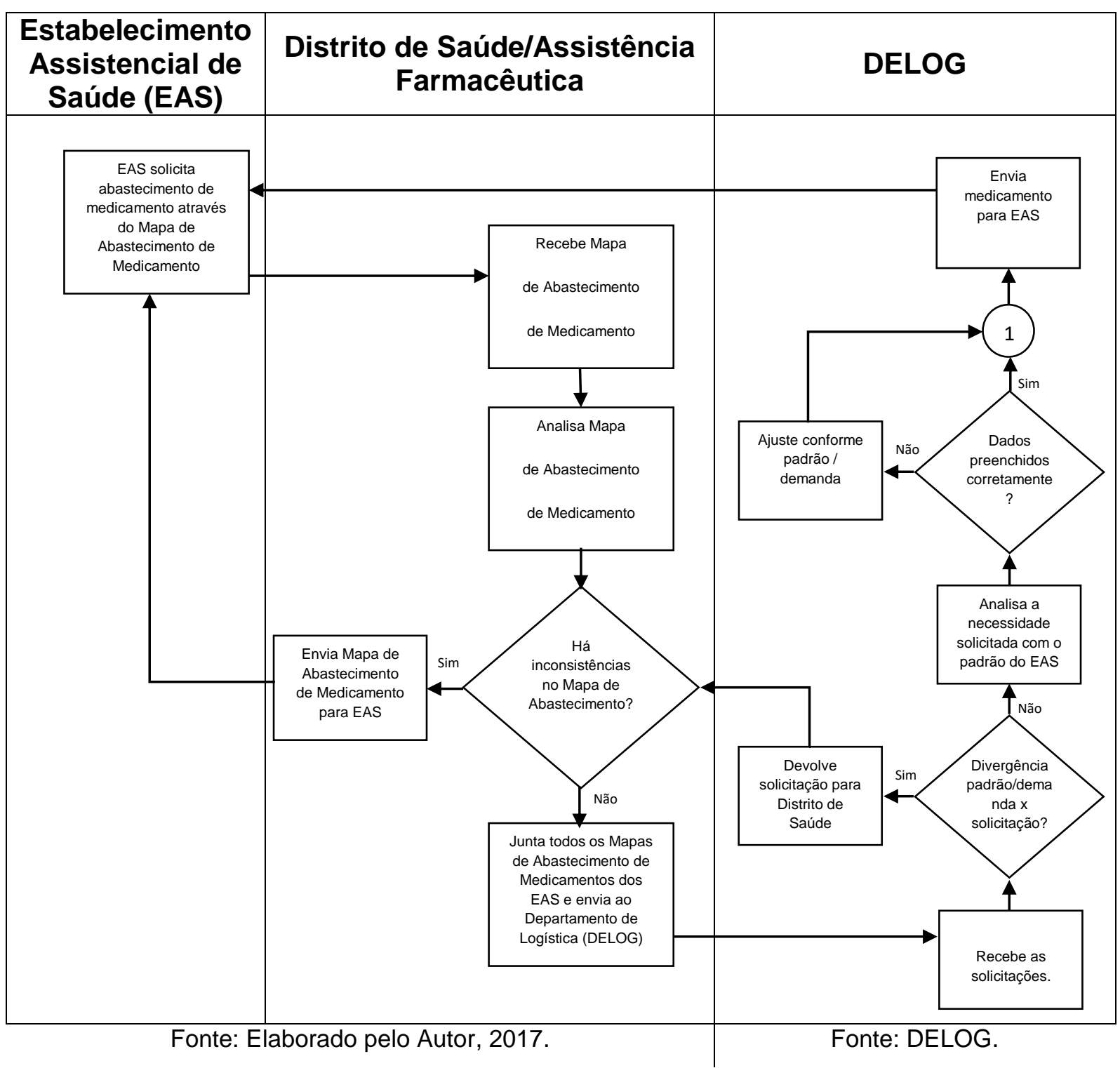

A Assistência Farmacêutica do Distrito de Saúde bem como a Divisão de Medicamentos do DELOG fazem uma análise manual no Mapa de Abastecimento de Medicamento do Estabelecimento Assistencial de Saúde a fim de encontrar alguma inconformidade, caracterizando o retrabalho e desperdício.

O envio físico do Mapa de Abastecimento de Medicamentos para o Estabelecimento Assistencial de Saúde para correção e posterior (re)envio também é uma atividade que não agrega valor. Como mencionado, a utilização dos carros oficiais para transporte de documentos é algo que depende da programação e disponibilidade da gestão de transportes da Secretaria. Uma vez corrigido o Mapa de Abastecimento de Medicamentos, o mesmo segue novamente o mesmo fluxo 
operacional, passando pelas mesmas correções e verificações, novamente caracterizando o retrabalho e desperdício.

O Sistema de Informação para Gestão de Medicamentos descrito no item anterior resolveria esta questão. Mas na ausência de um Sistema de Informação, propõe-se o Fluxo Operacional abaixo para o abastecimento de medicamentos nos EAS.

O Estabelecimento Assistencial de Saúde elabora o Mapa de Abastecimento de Medicamento e envia diretamente ao Departamento de Logística conforme o Calendário de Abastecimento.

A análise do Mapa de Abastecimento de Medicamento passa a ser feita na Divisão de Medicamentos e Insumos para a Saúde/DELOG através do Sistema de Estoque. O Sistema deverá informar as inconsistências no Mapa de Abastecimento.

Caso alguma inconsistência seja detectada, o Mapa de Abastecimento de Medicamento será encaminhado para o Distrito de Saúde pertencente àquele EAS. Os farmacêuticos da Assistência Farmacêutica devem fazer as correções necessárias no Mapa de Abastecimento, orientar o EAS sobre os erros detectados a fim de serem evitados no futuro e enviar o Mapa de Abastecimento de Medicamento com as devidas correções ao DELOG.

Através deste novo Fluxo Operacional o processo de distribuição de medicamentos ficará mais eficiente, menos burocrático, evitando retrabalhos e desperdícios, customizando o tempo dos servidores e dos serviços prestados a população, contribuindo substancialmente para a diminuição do lead time no abastecimento do medicamento. 
Quadro 40 - Proposta de Fluxo Operacional Abastecimento de Medicamentos EAS

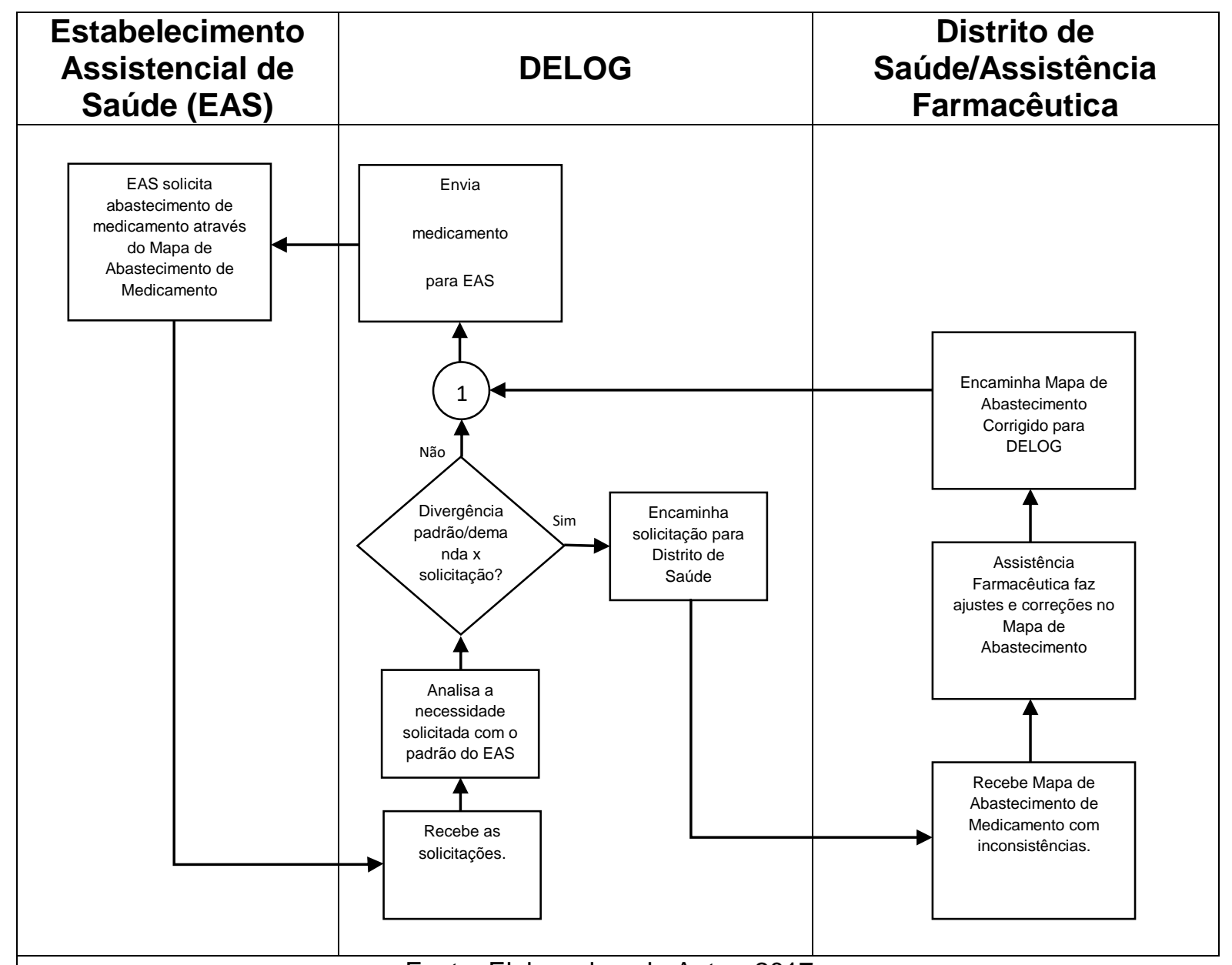

Fonte: Elaborado pelo Autor, 2017.

\subsubsection{Diminuir o Lead Time no Abastecimento de Medicamento}

O tempo de ciclo ou lead time, segundo os teóricos do Lean Manufacturing, é o tempo necessário para completar a atividade desde o momento do input inicial do processo até o momento do output (ANACLETO, et al., 2010). Na mesma direção, Prates e Bandeira (2011) destacam que o Lead Time é o tempo necessário para entregar um serviço ou produto. Vai desde o pedido inicial até a entrega do produto ao cliente que o solicitou. Os autores destacam ainda que quanto menor o Lead Time maior é a economia com os custos.

O Lead Time do abastecimento de medicamentos (logística de distribuição) inicia com o pedido de abastecimento de medicamentos através do Mapa de Abastecimento de Medicamento, e finaliza quando os medicamentos são entregue pelo DELOG na Unidade de Saúde. 
Analisando o Calendário de Abastecimento referente o segundo semestre de 2016 do DELOG (Figura 18), verifica-se uma média de 6 dias entre a data limite para envio do Mapa de Abastecimento ao DELOG e o inicio da distribuição dos medicamentos nas Unidades de Saúde.

Entrementes, este gap de 6 dias (em média) refere-se ao envio do Mapa de Abastecimento de Medicamento pela Assistência Farmacêutica do Distrito de Saúde, logo, a Unidade de Saúde precisa enviar o Mapa para o Distrito de Saúde com mais antecedência, para que o mesmo proceda às análises e correções conforme já exposto.

Figura 18 - Calendário de Abastecimento DELOG (Segundo semestre 2016) CALENDÁRIO DE ABASTECIMENTO - ANO 2016 (JULHO À DEZEMBRO)

\begin{tabular}{|c|c|c|c|c|c|c|c|c|c|}
\hline $\begin{array}{l}N^{\circ} \\
\text { Ord }\end{array}$ & ZONA & UNIDADE DE SAÚDE & & JUL & AGO & SET & OUT & NOV & DEZ \\
\hline 1 & \multirow{22}{*}{ E } & Laboratório Distrital & \multirow{12}{*}{ 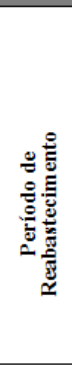 } & \multirow{12}{*}{ 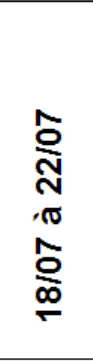 } & \multirow{12}{*}{ 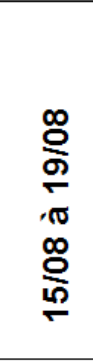 } & \multirow{12}{*}{ 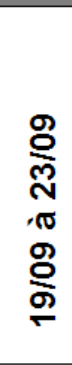 } & \multirow{12}{*}{$\begin{array}{l}\stackrel{0}{\Sigma} \\
\underset{N}{N} \\
\text { 을 } \\
\stackrel{ }{=}\end{array}$} & \multirow{12}{*}{$\begin{array}{l}\underset{丶}{ \pm} \\
\stackrel{\sigma}{\sigma} \\
\stackrel{\sigma}{\sigma}\end{array}$} & \multirow{12}{*}{ 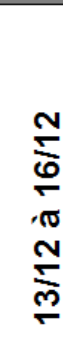 } \\
\hline 2 & & \begin{tabular}{|l} 
Policlinica Antonio Reis \\
\end{tabular} & & & & & & & \\
\hline 3 & & SAMU & & & & & & & \\
\hline 4 & & UBS Frank Calderon & & & & & & & \\
\hline 5 & & UBS Lourenço Borghi & & & & & & & \\
\hline 6 & & UBS Lúcio Flávio V. Dias & & & & & & & \\
\hline 7 & & UBS Olavo das Neves (Matinha) & & & & & & & \\
\hline 8 & & UBS São Francisco & & & & & & & \\
\hline 9 & & UBS Theodomiro Garrido & & & & & & & \\
\hline 10 & & UBS Almir Pedreira & & & & & & & \\
\hline 11 & & \begin{tabular}{|l|} 
UBS José Figlioulo \\
\end{tabular} & & & & & & & \\
\hline 12 & & \begin{tabular}{|l|} 
Policlinica Castelo Branco \\
\end{tabular} & & & & & & & \\
\hline 13 & & UBS Dr. Luiz Montenegro & & \multirow{10}{*}{$\stackrel{\bar{\Xi}}{\stackrel{\bar{m}}{\leftrightarrows}}$} & \multirow{10}{*}{$\begin{array}{l}\text { 엄 } \\
\frac{\mathbb{0}}{0}\end{array}$} & \multirow{10}{*}{ 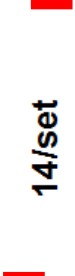 } & \multirow{10}{*}{$\begin{array}{l}\text { 호 } \\
\stackrel{0}{\tau}\end{array}$} & \multirow{10}{*}{ 옹 } & \multirow{10}{*}{$\frac{N}{\stackrel{N}{0}}$} \\
\hline 14 & & UBS Japiim & & & & & & & \\
\hline 15 & & UBS José Rayol dos Santos & & & & & & & \\
\hline 16 & & UBS Megumo Kado & 象 & & & & & & \\
\hline 17 & & UBS Morro da Liberdade & 욜 & & & & & & \\
\hline 18 & & UBS Petropólis & 这 & & & & & & \\
\hline 19 & & UBS Santa Luzia & & & & & & & \\
\hline 20 & & UBS Theomário P. da Costa & & & & & & & \\
\hline 21 & & UBS Vicente Pallotti & If & & & & & & \\
\hline 22 & & 53 UBSF+CEO+Escolas (Odonto) & & & & & & & \\
\hline
\end{tabular}

Fonte: DELOG, 2016.

Analisando outro dado, Figura 19, um cronograma de abastecimento de medicamentos elaborado pela Assistência farmacêutica do Distrito de Saúde, verifica-se que a Unidade de Saúde tem 2 dias para enviar seu Mapa de Abastecimento para a Assistência Farmacêutica do DISA. Por sua vez a Assistência farmacêutica do DISA tem até o sexto (6ํ) dia anterior ao início do abastecimento para enviar o Mapa de Abastecimento ao DELOG, logo, a Assistência Farmacêutica do DISA também tem 2 dias para fazer as análises e correções nos Mapas de Abastecimento das Unidades de Saúde, como pode ser visto no Quadro 41. 
Figura 19 - Cronograma de Abastecimento de Medicamentos

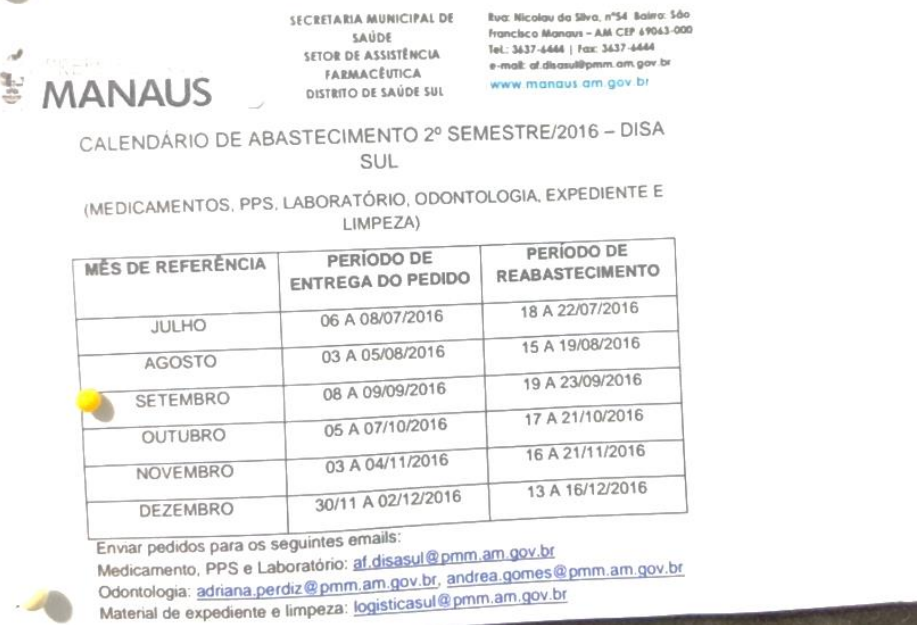

Fonte: Pesquisa de campo, 2017.

A partir destas informações (Figura 18 e Figura 19), tomando como referência outubro/2016, pode-se mensurar os tempos, conforme Quadro 41.

Quadro 41 - Mensuração de Tempos nos Pedidos de Abastecimento

\begin{tabular}{|c|c|c|c|}
\hline $\begin{array}{c}\text { Tempo para } \\
\text { Unidade de Saúde } \\
\text { enviar Mapa }\end{array}$ & $\begin{array}{c}\text { Tempo para } \\
\text { Assistência } \\
\text { Farmacêutica } \\
\text { analisar o Mapa }\end{array}$ & $\begin{array}{c}\text { Tempo para DIVAL } \\
\text { analisar Mapa e } \\
\text { separar } \\
\text { medicamento }\end{array}$ & $\begin{array}{c}\text { Tempo para } \\
\text { Abastecimento } \\
\text { DELOG } \\
\text { na Unidade de } \\
\text { Saúde }\end{array}$ \\
\hline 05 a $07 / 10 / 2016$ & 08 a $10 / 07 / 2016$ & 11 a $16 / 10 / 2016$ & 17 a 21/10/2016 \\
\hline 2 dias & 2 dias & 5 dias & 4 dias \\
\hline
\end{tabular}

Fonte: Elaborador pelo Autor, 2017.

A Unidade de Saúde tem 2 dias para enviar o Mapa de Abastecimento de Medicamento. A Assistência Farmacêutica do DISA tem 2 dias para fazer a análise no Mapa e enviar ao DELOG. No DELOG, a Divisão de Almoxarifado (DIVAL) tem 5 dias para fazer nova análise no Mapa e iniciar o Processo de separação dos medicamentos. $\mathrm{O}$ abastecimento dos medicamentos na Unidade de Saúde leva um tempo de 4 dias.

Através do Value Stream Mapping (VSM) é possível melhor visualizar estes processos com seus tempos, e principalmente o Lead Time atual para o abastecimento de medicamentos. 
Figura 20 - Value Stream Mapping Presente - Abastecimento de Medicamentos

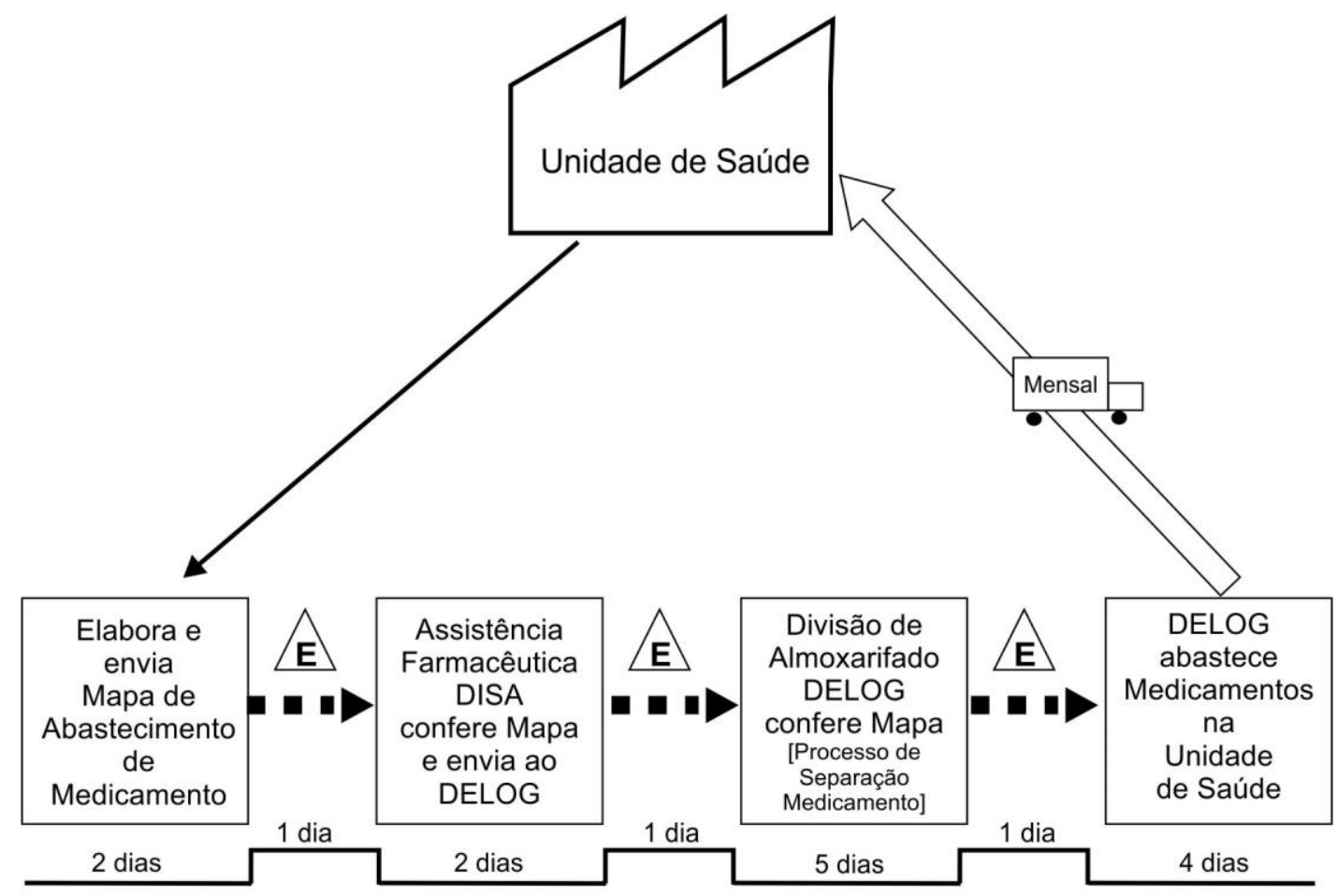

Lead Time: 16 dias

Fonte: Elaborado pelo Autor, 2017.

Um Lead Time de 16 dias entre a solicitação de medicamento através do Mapa de Abastecimento e a entrega do medicamento na Unidade de Saúde é um tempo longo e tem impacto negativo no dispensação de medicamentos aos usuários de saúde. Este Lead Time nem mesmo pode ser previsto no Mapa de Abastecimento, pois como dito anteriormente, cada Estabelecimento Assistencial de Saúde tem um padrão de medicamento. Este padrão estipula quais medicamentos e a quantidade deste medicamento.

Tomando como exemplo fictício de um remédio "YXZ" numa Unidade Básica de Saúde da Família (UBSF). É estipulado um padrão de 100 caixas deste remédio na Unidade de Saúde. Quando da solicitação de abastecimento, o profissional de saúde verifica que no estoque há 5 caixas do medicamento "YXZ", logo, seu pedido ao DELOG será de 95 caixas. Não é permitido fazer uma solicitação maior a fim de cobrir o Lead Time de 16 dias entre a solicitação e o abastecimento.

Com a implantação de um Sistema de Informação e mudando o Fluxo Operacional, como sugerido acima, existe uma grande probabilidade de redução do Lead Time. 


\subsection{VSM PRESENTE DA GESTÃO DA CADEIA DE SUPRIMENTOS DE MEDICAMENTOS: A MONTANTE}

Como dito anteriormente, o Value Stream Mapping (VSM) ou Mapeamento do Fluxo de Valor, é uma ferramenta que auxilia na compreensão do fluxo de materiais e informações, visando à melhoria contínua da produção (LIBRELATO et al., 2014) e a eliminação de desperdícios (SETH et al., 2008) através da criação de um mapa (TABANLI; ERTAY, 2013), descrevendo o caminho que este material/informação percorre no fluxo de valor (SETH et al., 2008).

Para a construção do VSM da Gestão da Cadeia de Suprimentos de Medicamentos foi escolhido o Processo Administrativo de Aquisição de Medicamentos através de Ata de Registro de Preço como atividade/produto a ser analisado e posteriormente ter seu fluxo mapeado.

Como o VSM trata de uma construção presente, mais próxima da realidade possível, foi escolhido apenas o ano de 2015 dentre o recorte temporal da pesquisa (2013 a 2015) para análise dos dados referentes os Processos de Aquisição de Medicamentos a fim de subsidiar a elaboração do Mapeamento do Fluxo de Valor Presente dos mesmos.

\subsubsection{Dados para Construção do VSM Presente}

No ano de 2015, o Departamento de Logística, através da Divisão de Medicamentos expediu cinquenta (50) Memorandos para aquisição de medicamentos através de Ata de Registro de Preços, gerando 50 Processos Administrativos.

Entre a expedição dos Memorandos e a formalização do Processo Administrativo no PROTUS, os Memorando passaram em média 4,9 dias na Subsecretaria de Gestão Administrativa e Planejamento aguardando autorização para "processar".

Entre a formalização do Processo Administrativo no PROTUS e a emissão da Nota de Empenho, o Processo Administrativo tramita por vários Departamentos/Setores na SEMSA. Em média este tempo é de 40 dias.

Devido a diversas mudanças no Fluxo Operacional na tramitação dos Processos Administrativos ao longo do ano de 2015, não foi possível mensurar o 
Lead Time em cada Departamento/Setor. Mas este é um dado relevante que indica falta de padronização deste Processo, ocasionando "mudas" de deslocamento.

Após a emissão da Nota de Empenho pela Administração Pública, o Fornecedor tem, conforme Edital de Licitação, em média 5 dias para dar ciência e retirar a Nota de Empenho. Dados da pesquisa indicam que em média os Fornecedores têm demorado 20,1 dias para retirar a Nota de Empenho62.

Uma vez que o Fornecedor toma ciência da Nota de Empenho, conforme o Edital de Licitação, ele tem até dias 30 para fazer a entrega total dos itens descritos na Nota de Empenho com suas respectivas quantidades. Entretanto, dados da pesquisa mostraram que o Fornecedor faz em média 2,9 entregas de medicamentos ao DELOG, sendo a primeira entrega de medicamentos em média 40,8 dias após o recebimento da Nota de Empenho e a última entrega, em média, 31,9 dias após a primeira.

Este ciclo do Processo Administrativo de Aquisição de Medicamentos através de Ata de Registro de Preços, no ano de 2015, desde o input (expedição do Memorando) até o output (ultima entrega de medicamento) tem um Lead Time de 137,7 dias.

\subsubsection{Identificação das "mudas"}

A partir do Mapeamento do Fluxo de Valor Presente dos Processos Administrativos de Aquisição de Medicamento através de Ata de Registro de Preço, Figura 21, é possível identificar as mudas, ou seja, o que não está agregando valor.

Para tanto, será utilizado como fundamento para esta identificação e análise as Categorias de Desperdício na Manufatura e no Escritório (Quadro 12) proposto por Seraphim et al. (2010).

\footnotetext{
62 Para o calculo da média de tempo entre a emissão da Nota de Empenho e a Data de recebimento da Nota de Empenho pelo Fornecedor, não foram computador registros onde a (1) Data da Emissão do Empenho era inferior da Data de Formalização no PROTUS e (2) Data de Emissão do Empenho fosse menor igual a 14 dias após a Formalização no PROTUS.
} 
Figura 21 - Mapeamento do Fluxo de Valor Presente Processo de Aquisição de Medicamento

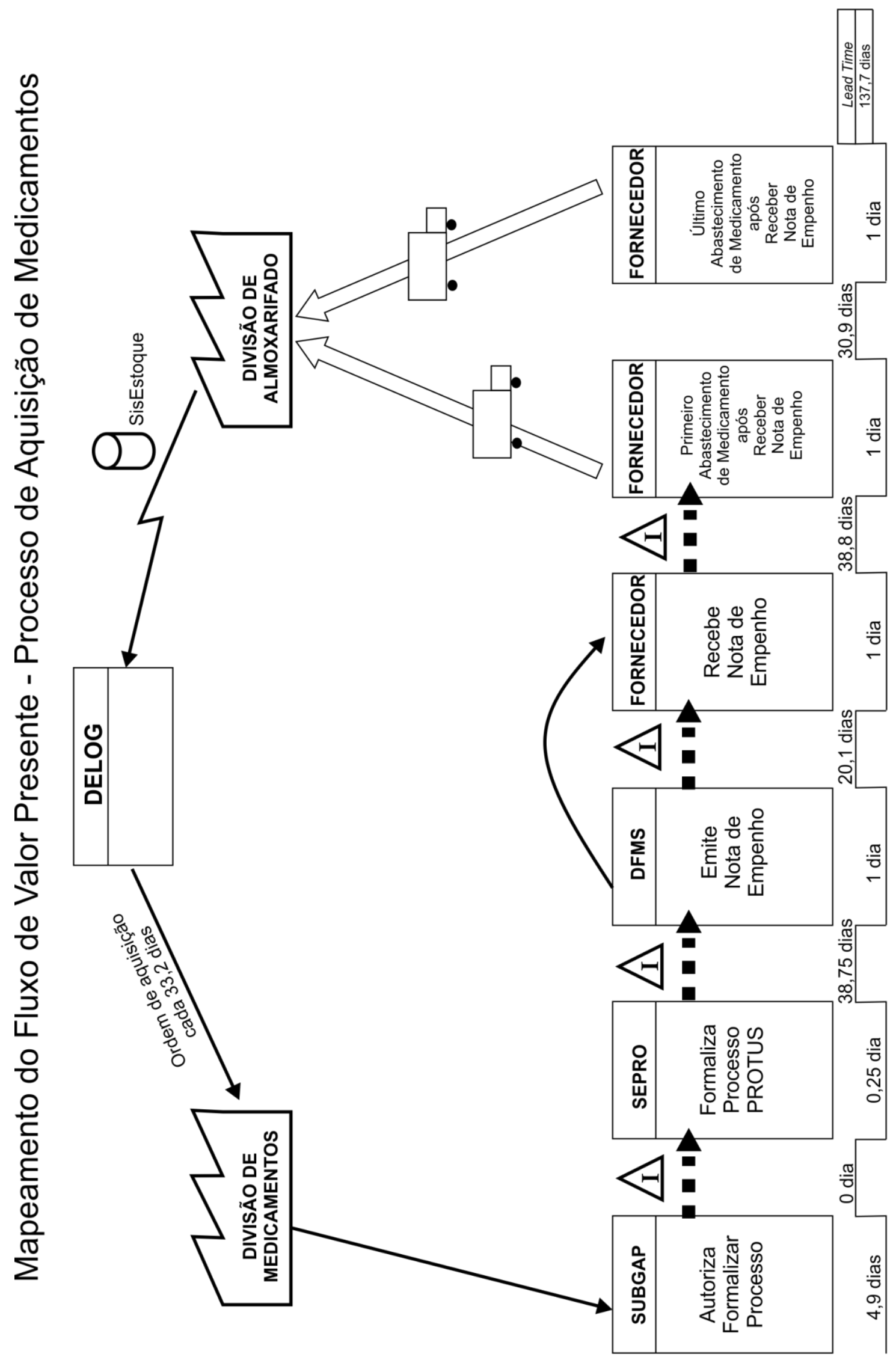

Fonte: Elaborado pelo autor, 2017. 


\subsubsection{Processamento Sem Valor}

O tempo que o Memorando de aquisição de medicamentos passa na Subsecretaria de Gestão Administrativa e Planejamento aguardando autorização para "processar" é um exemplo de processamento sem valor. Foram em média 4,9 dias com o Memorando parado esperando apenas uma assinatura.

\subsubsection{Superprodução e Inventário}

Não obstante o fato do Departamento de Logística estar racionalizando a formalização de Processos Administrativos para aquisição de medicamentos durante os anos de 2013 a 2015, como pode ser visto no Quadro 42, ainda assim, 50 Processos Administrativos para aquisição de medicamentos no ano de 2015 é um número alto, é uma superprodução.

Cinquenta Processos Administrativos têm custo elevado para a tramitação, geram maior fluxo de controle e acompanhamento dos processos e conforme a pesquisa, não diminui o Lead Time para a entrega do medicamento pelo Fornecedor.

Quadro 42 - Processos Administrativos para Aquisição de Medicamentos

\begin{tabular}{|c|c|}
\hline Ano & Qtde. Processos \\
\hline 2013 & 90 \\
\hline 2014 & 81 \\
\hline 2015 & 50 \\
\hline
\end{tabular}

Fonte: Dados da Pesquisa, 2017.

\subsubsection{Defeito}

É possível identificar algumas situações de defeito no VSM Presente do Processo de Aquisição de medicamentos.

Falta de padrão no Fluxo para tramitação dos Processos Administrativos. A pesquisa identificou que ao longo do ano de 2015 aconteceram várias mudanças no Fluxo. A falta de padrão induz a erros, gera movimentação desnecessária (Transporte) e aumenta o Lead Time. 
Quadro 43 - Exemplos de Diferentes Fluxos de Tramitação de Processos de Aquisição de Medicamentos - 2015

\begin{tabular}{|c|c|c|c|c|c|c|c|c|c|c|c|}
\hline & $\mathbf{1}$ & $\mathbf{2}$ & $\mathbf{3}$ & $\mathbf{4}$ & $\mathbf{5}$ & $\mathbf{6}$ & $\mathbf{7}$ & $\mathbf{8}$ & $\mathbf{9}$ & $\mathbf{1 0}$ & $\mathbf{1 1}$ \\
\hline A & SEPRO & DEADM & GEREP & DPLAN & GEXOR & GEREP & SEPRO & DELOG & & & \\
\hline B & SEPRO & DEADM & GEREP & DPLAN & DFMS & CGOF & DFMS & GEXOR & GEREP & SEPRO & DELOG \\
\hline C & SEPRO & DEADM & GEREP & DPLAN & CGOF & DPLAN & GEXOR & GEREP & SEPRO & DELOG & \\
\hline D & SEPRO & GEREP & DFMS & CGOF & DFMS & GEXOR & DICSO & SEPRO & DELOG & & \\
\hline E & SEPRO & GEREP & DFMS & GEXOR & DICSO & SEPRO & DELOG & & & & \\
\hline
\end{tabular}

Fonte: PROTUS.

Conforme o Quadro 43, houve ao menos 5 diferentes Fluxos na tramitação dos Processos Administrativos ao longo de 2015.

Erros de digitação. Sempre que é detectado um erro de digitação ou um dado errado no texto do Memorando, o Processo Administrativo retorna para o DELOG fazer as correções.

Incorreta alimentação do PROTUS. A pesquisa também revelou que o Sistema de Protocolo (PROTUS) não tem sido alimentado corretamente. Há casos onde o tempo de tramitação do Processo Administrativo dentro do Setor é zero, dando a entender que o Processo Administrativo entrou e saiu no mesmo dia. Entretanto o tempo de tramitação entre Setores é alto, indicando que o Processo Administrativo chegou ao Setor mas não foi recebido via Sistema.

\subsubsection{Transporte e Movimentação}

O Processo Administrativo é um documento físico, e conforme vai tramitando em cada Departamento/Setor, despachos e novos documentos são acrescentados ao Processo Administrativo. Cada movimento feito pelo Processo Administrativo precisa ser registrado no PROTUS.

Dependendo do Fluxo de tramitação vigente, este também pode ser um desperdício. Tomando como exemplo a linha "B" do Quadro 43, o Processo Administrativo passou por 10 locais até chegar ao DELOG.

A pesquisa mostra que existe uma movimentação excessiva do Processo Administrativo e cada Departamento/Setor tem suas prioridades e demandas e dão ao Processo de Aquisição de medicamentos diferentes tratamentos. 


\subsubsection{Espera}

O não cumprimento dos prazos estabelecidos em Edital pelos fornecedores é um sério problema e tem impacto direto na Gestão da Cadeia de Suprimentos da SEMSA, pois ele mina o planejamento estratégico do DELOG.

Via de regra, o Edital da Licitação preconiza que o Fornecedor tem prazo de 5 dias após a emissão da Nota de Empenho para recebê-la. A pesquisa indica que em média os Fornecedores estão demorando 20,1 dias. Após o recebimento da Nota de Empenho, o Fornecedor precisa fazer a entrega total do Empenho em até 30 dias, entretanto, dados da pesquisa indicam que este tempo gira em torno de 72,7 dia em média.

\subsubsection{Identificação das restrições}

Como dito anteriormente, a Theory of Constraints (TOC) ou Teoria das Restrições, segundo Alves et al. (2011) é um método de gestão centrado na constante melhoria dos processos que restringem o fluxo da produção, objetivando melhorar continuamente o desempenho das operações. A Teoria das Restrições busca otimizar a produção, identificando as restrições do sistema, eliminando ou minimizando estas restrições, a fim de melhorar o desempenho da Organização.

Analisando o VSM Presente do Processo de Aquisição de Medicamentos, bem como os Dados da Pesquisa, pode-se eliminar a possibilidade de restrições (ou gargalos) em algumas etapas do processo.

Primeiro, recursos financeiros não representam uma restrição/gargalo. Os dados indicam que o valor dos recursos referentes à Dotação Orçamentária para a Assistência farmacêutica, têm sido suficientes para as aquisições de medicamentos.

Segundo, não obstante o fato da tramitação do Processo de Aquisição de Medicamento ter um longo lead time dentro dos Departamento/Setores da SEMSA, ainda assim, não representa a maior restrição/gargalo. Além do fato que com a aplicação de ferramentas como Lean Office, seria possível diminuir este tempo de tramitação dos Processos.

Terceiro, a Gestão da Cadeia por parte do Departamento de Logística não constitui uma restrição. Verifica-se na pesquisa um planejamento sistemático do 
DELOG para as aquisições dos medicamentos, inclusive com a racionalização dos Processos.

Logo, pode-se concluir que as restrições do sistema (ou gargalos) residem sobre os Fornecedores.

Os Fornecedores: (1) demoram em receber e tomar ciência da Nota de Empenho; (2) demoram em concluir a entrega dos medicamentos descritos na Nota de Empenhos; (3) em algumas ocasiões, não estão finalizando a entrega total do Empenho. Dados da pesquisa indicam que em 2015 apenas 88,65\% do valor total de empenhos válidos foram entregue ao DELOG.

Neste sentido, conforme a Teoria das Restrições, uma vez identificado a restrição, é preciso subordinar o sistema ao gargalo/restrição, ou seja, subordinar a aquisição de medicamentos à capacidade operacional dos Fornecedores de medicamentos da Secretaria Municipal de Saúde de Manaus.

\subsubsection{VSM Futuro}

Tendo identificado as mudas e as restrições no VSM atual, propõe-se um VSM futuro para a Gestão da Cadeia de Suprimentos de Medicamentos da Secretaria Municipal de Saúde de Manaus.

Por sua vez, este VSM futuro (Figura 22), é a base da proposta do modelo de otimização do Processo de Aquisição de Medicamentos na Rede Municipal de Saúde de Manaus, conforme o Objetivo Geral da pesquisa. 
Figura 22 - VSM Futuro Processo de Aquisição de Medicamento

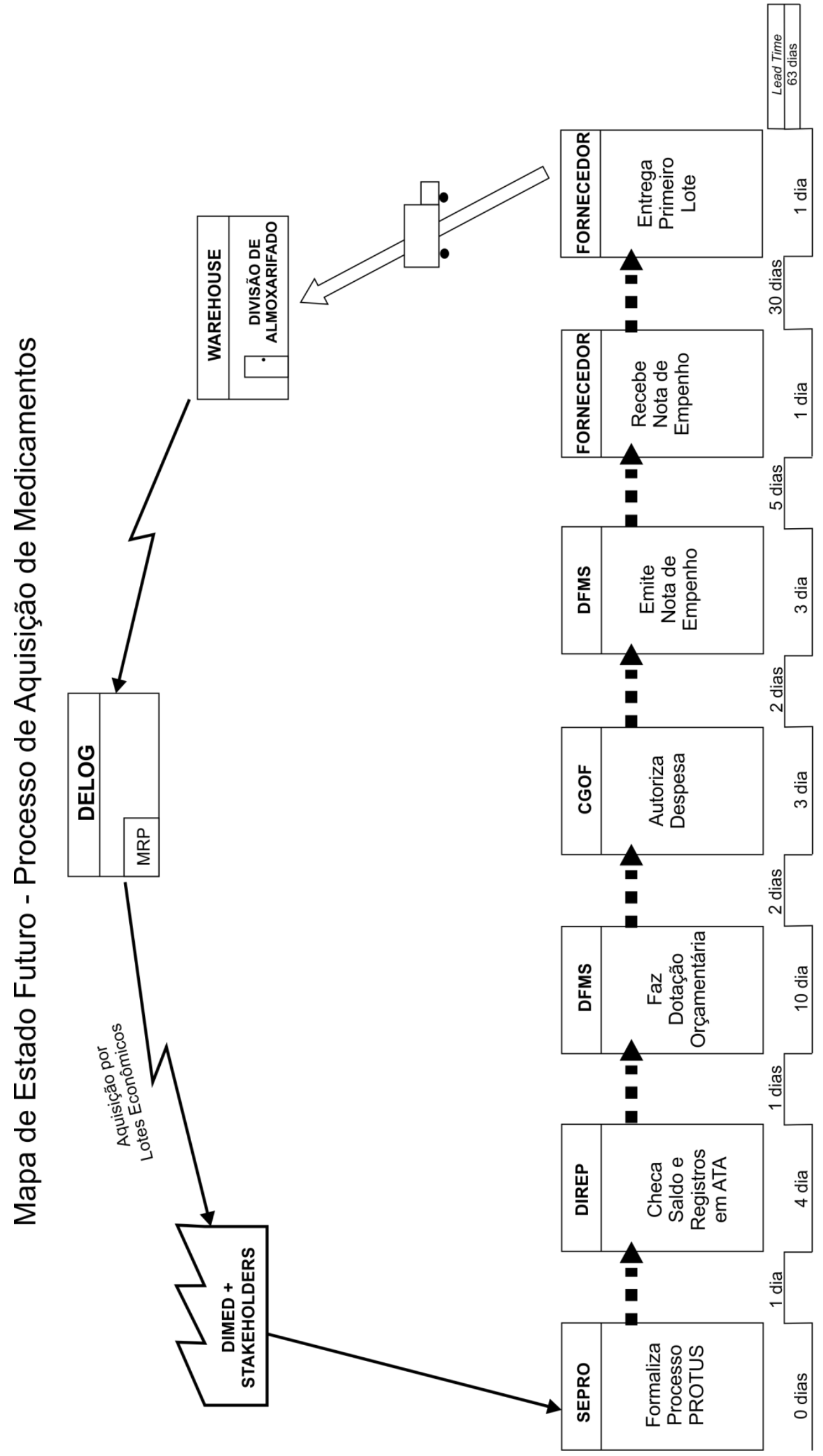

Fonte: Elaborado pelo autor, 2017. 


\subsection{PROPOSTA DE MODELO DE OTIMIZAÇÃO DO PROCESSO DE AQUISIÇÃO DE MEDICAMENTO}

Através do VSM Futuro, conforme Figura 22, propõe-se à Administração Pública um Modelo de otimização do Processo de Aquisição de medicamentos na Rede de Saúde ${ }^{63}$.

\subsubsection{Passo 1 - Planejar as Aquisições de Medicamentos}

O planejamento para a aquisição de medicamentos é o primeiro e fundamental passo para a Gestão da Cadeia de Suprimentos. É atribuída a Michael Porter a frase ${ }^{64}$, "sem um planejamento estratégico competente, ninguém sobreviverá nestes tempos de globalização".

Algumas variáveis devem ser levadas em consideração no planejamento das aquisições: (1) Análise Histórica do Consumo; (2) Consumo Médio Mensal; (3) Giro do Estoque; (4) Estoque de Segurança; (5) Lote Econômico; (6) Previsão de Consultas Médicas; (7) Crescimento da População; (8) Expansão da Rede de Saúde.

A análise histórica do consumo de medicamentos dos últimos 12, 24 e 36 meses mostram a demando por medicamentos por parte da população, onde a partir de estudos, análises gráficas e demonstrações estatísticas, pode-se estabelecer um padrão de cosumo de medicamentos por parte dos usuários/pacientes do SUS.

O consumo médio mensal é outro dado relevante, pois mostra um retrato mais atual do consumo de medicamentos, alinhado ao Giro do Estoque é possível fazer uma função matemática relacionando estes dois dados.

$O$ estoque de segurança devido às condições geográficas da Cidade de Manaus, precisa considerar um estoque de ao menos sessenta e três (63) dias, que é o lead time de aquisição de medicamentos proposto.

\footnotetext{
63 Para a exequibilidade deste modelo alguns pressupostos são necessários: (1) Existência de Sistema de Informação da Cadeia de Suprimentos (e não apenas um Sistema de Estoque) que gerencie todas as etapas da Cadeia: Input, Processamento e Output; (2) Controle da distribuição de medicamentos para o usuário/paciente, feito pela Unidade de Saúde. Este procedimento é conditio sine qua non para o Planejamento de aquisição de medicamentos.

${ }^{64}$ Michael Porter é considerado um dos maiores teóricos do Planejamento Estratégico. Citação ad tempora.
} 
O estabelecimento de Lote Econômico para as aquisições é outro ponto crucial, pois vai auxiliar a racionalizar os pedidos de aquisição de medicamentos, diminuir os custos administrativos e gerir melhor o estoque.

A demanda de medicamentos está intrinsecamente relacionada à consulta com o profissional médico. Sem uma consulta médica não há receita e sem receita médica não há medicamentos, logo, a previsão de consultas médicas é extremamente importante para a aquisição de medicamento. Existem várias ferramentas gerenciais vinculadas a saúde pública que auxiliam nesta previsão, como por exemplo, a (1) Programação Mensal de Produção (PMP) e o (2) Programa para Gestão por Resultados na Atenção Básica (ProGRAB). Estas ferramentas, a partir de dados populacionais e capacidade instalada, indicam a quantidade de consultas médicas que serão realizadas em um determinado período de tempo.

O Instituto Brasileiro de Geografia e Estatística (IBGE) disponibiliza dados referentes à população bem como sua projeção de crescimento. A projeção de crescimento da população também auxilia no planejamento das aquisições de medicamentos, pois o crescimento populacional tem impacto direto da demanda por medicamentos.

E por último, o planejamento da Administração Pública sobre a Expansão da Rede de Saúde. Quantas Unidades de Saúde serão inauguradas ao longo do ano? Qual sua tipologia? A Rede de Saúde vai cobrir quais áreas populacionais? Com estas informações da Gestão será possível planejar melhor as aquisições.

O Passo 1 - Planejamento das Aquisições não é uma tarefa fácil, mas é de uma relevância extrema para a Gestão da Cadeia de Suprimentos de Medicamentos, especialmente no que tange à aquisição de medicamentos.

4.6.2 Passo 2 - Diminuir a quantidade de ordens de aquisição usando Lotes Econômicos

Como demonstrado no Quadro 25, o DELOG emite várias ordens de aquisição de medicamentos através de Processos Administrativos de Aquisição de Medicamentos. Este é um modelo que, segundo dados da pesquisa, não tem dado o resultado esperado, pois os medicamentos continuam demorando a chegar além de gerar um custo extra para a Administração Pública, conforme Quadro 26. 
Desta forma, propõe-se como Segundo Passo para otimizar o Processo de Aquisição de Medicamentos: diminuir a quantidade de ordens de aquisição.

A proposta consiste em após o Planejamento das aquisições, o DELOG emitir de uma única vez as ordens de aquisição de medicamento para um ano (365 dias), fracionada em Lotes Econômicos.

Diminuindo a quantidade de ordens de aquisição de medicamentos ao ano, acarretará na redução dos custos com a tramitação dos processos, melhoria da gestão dos processos do DELOG, racionalização da Gestão da Cadeia de Suprimentos e melhoria da gestão os recursos financeiros do Orçamento Público.

Em relação ao Fornecedor, o mesmo terá mais condições de Gestão Operacional junto aos seus Fornecedores Primários (Laboratório Fabricantes) podendo ajustar a produção e a distribuição de acordo com os Lotes, a fim de atender as demandas do Município.

A diminuição da quantidade de ordens de aquisição não irá comprometer o orçamento público, pois conforme a pesquisa indicou utilizou-se apenas $53,33 \%$ em média dos recursos destinados à Dotação Orçamentária para a Assistência Farmacêutica nos anos de 2013 a 2015. Ao contrário, a aquisição única no início do ano garante a Gestão da SEMSA que os recursos não serão contingenciados.

Existe ainda há possibilidade de fazer uma melhor gestão da Dotação Orçamentária da Assistência Farmacêutica. Uma vez estabelecida o valor total da aquisição de medicamentos/ano é possível administrar melhor o valor restante da Dotação Orçamentária para a aquisição de bens ou equipamento para as Unidades de Saúde.

Outro benefício está na Gestão das Ata de Registro de Preços, pois não são poucos os casos de que uma Ata perde a validade ainda tendo saldo para aquisição, ou então o contrário, objetivando usar o saldo total de uma Ata prestes a ter sua validade suspensa, o Administrador Público emite uma ordem de aquisição de medicamentos com valor muito baixo. Empenhos com valores baixos além de gerarem custo operacional para a Administração Pública, também têm custo operacional para os Fornecedores. 
4.6.3 Passo 3 - Programar a entrega dos Lotes

Uma vez emitida todas as ordens de aquisição, fracionadas em Lotes Econômicos, pode-se programar junto aos Fornecedores e Fornecedores Primários (Laboratório Fabricantes) a entrega dos mesmos.

Com a análise feita no Passo 1, do consume médio mensal e giro do estoque é possível estabelecer uma quantidade " $\mathrm{n}$ " de dias para o abastecimento de cada Lote, assim é possível programar as entregas de medicamentos.

Suponhamos que no mês de janeiro (de um ano qualquer) o DELOG emita seis ordens de aquisição, ou seja, abertura de seis Processos Administrativos para aquisição de medicamentos para todo $O$ ano. Com a análise do consumo médio mensal e giro do estoque o DELOG pode pactuar com o Fornecedor que cada Lote seja entregue em "n" dias.

\subsubsection{Passo 4 - Envolver os Stakeholders no Planejamento da Aquisição}

A Cadeia de Suprimentos é formada por vários elos. Ballou (2006) é tacito ao afirmar que existe uma dependência entre os vários elos da cadeia, por isso a necessidade de envolver os parceiros na Gestão da Cadeia, pois ganhos significativos podem advir desta gestão conjunta.

Neste sentido, o Quarto Passo para otimizar o Processo de Aquisição de Medicamentos é envolver todos os Stakeholders no planejamento da aquisição de medicamentos.

O tema medicamentos tem um apelo e comoção social relevante na sociedade, deforma que é temerário circunscrever a apenas um setor técnico, no caso a Divisão de Medicamentos e Insumos para a Saúde/DELOG, a responsabilidade única pelo planejamento da aquisição dos medicamentos, por isso a importância e necessidade de envolver todos os Stakeholders.

Como exemplo de Stakeholders envolvidos na Cadeia pode-se citar: (1) Fornecedores, (2) Representantes do Laboratórios/Fábricas, (3) Representantes das Transportadoras, (4) Representantes da Alfândega, (5) Representantes de Órgãos de Fiscalização e Controle, (6) Representante da Subsecretaria de Gestão Administrativa e Planejamento, (7) Representantes dos Setores/Departamentos da SEMSA (DEPLAN, DEADM, DFMS), (8) Representantes da Assistência 
Farmacêutica/SEMSA, (9) Representantes da Secretaria Municipal de Finanças e (10) Representantes de Associações de Usuários do SUS.

Destaque especial para dois elos na Cadeia. Primeiro os próprios Fornecedores. O Fornecedor não pode tomar conhecimento de uma aquisição de medicamento apenas quando da Emissão da Nota de Empenho. Caso o mesmo participe do Planejamento da aquisição de medicamentos poderá se programar juntos aos fabricantes para a nova demanda, mesmo que ainda não tenha sido emitida a Nota de Empenho e não há o compromisso de pagar por parte da Administração Pública, mas a participação de representante da Secretaria Municipal de Finanças no bojo do processo dá segurança que o mesmo será empenhado.

Outro parceiro indispensável no planejamento das aquisições é a Assistência Farmacêutica da SEMSA. Conforme Brasil (2006) compete a Assistência Farmacêutica: (1) gerenciar o processo de aquisição de medicamentos; (2) gestão de estoque; (3) distribuir e dispensar medicamentos; (4) promover uso racional de medicamentos; etc. Conforme demonstrado na pesquisa, não há participação na Gestão da Cadeia pela Assistência Farmacêutica.

A Administração Pública teria um ganho de qualidade com a inserção do profissional farmacêutico envolvido no processo de gestão dos medicamentos, pois o profissional farmacêutico está na Unidade de Saúde e tem maior percepção sobre os estoques de medicamentos, aumento de demandas, baixo consumo, etc.

Conforme Programação Mensal de Produção $(\mathrm{PMP})^{65}$ não há pactuação de produtividade para o profissional farmacêutico, ficando o mesmo restrito a dispensação de medicamentos e orientação sobre prescrição médica, subutilizando um parceiro que poderia ter um papel mais proeminente na Gestão da Cadeia.

A participação de parceiros da cadeia no Planejamento da aquisição dos medicamentos terá grande impacto para Gestão da Cadeia de Suprimentos.

\footnotetext{
65 Programação Mensal de Produção (PMP) é a pactuação mínima de procedimentos de saúde que os profissionais devem desenvolver durante o mês na Unidade de Saúde. Por exemplo: o médico tem uma quantidade estimada de $X$ pacientes para atender. $O$ Agente Comunitário de Saúde tem uma quantidade estimada de $\mathrm{Y}$ casas para visitar. Fonte: DICAR/SEMSA.
} 
4.6.5 Passo 5 - Padronizar o Fluxo de Tramitação dos Processos

A pesquisa demonstrou que não há uma padronização no Fluxo para a tramitação dos Processos de Aquisição de Medicamentos, fato este que não agrega valor e gera desperdício.

O Quinto Passo para otimizar o Processo de Aquisição de Medicamentos é padronizar o fluxo para a tramitação dos processos de aquisição estabelecendo num lead time máximo de 32 dias entre a formalização do Processo Administrativo junto ao PROTUS e o recebimento da Nota de Empenhos pelo Fornecedor ${ }^{66}$.

Não seria mais necessário o Memorando de aquisição ir para a Subsecretaria de Gestão Administrativa e Planejamento esperar a autorização para processar, pois subentende-se que representantes da Subsecretaria estiveram na elaboração do Planejamento da Aquisição. O Memorando de aquisição segue direto para o (1) SEPRO, a fim de abrir formalmente o Processo Administrativo. Em Seguida para o (2) DIREP para as verificações e checagens da Ata de Registro de Preços. Aqui outra mudança, a dotação orçamentária passa a ser feita no (3) Departamento do Fundo Municipal de Saúde (DFMS) e não mais no Departamento de Planejamento (DPLAN). Após dotação, o Processo Administrativo segue para a (4) CGOF (que também participou do Planejamento de Aquisição) para autorizar a despesa. Processo volta para o (5) DFMS para emissão da Nota de Empenho e entrega da mesma ao (6) Fornecedor, que tem 30 dias para entregar o Lote completo.

\subsubsection{Passo 6 - Aprimorar a Gestão de Materiais}

Com uma única aquisição no ano, ainda que fracionada em vários Lotes, não apenas um grande volume financeiro será gerado, mas também uma grande quantidade de medicamentos que precisa ser adequadamente armazenada, demandando assim um aprimoramento da logística interna na Gestão de Materiais.

Além de ajustar as aquisições de medicamentos (input) e a entrega do medicamento ao usuário final (output), também se faz necessário aprimorar as práticas da Gestão de Materiais, ou logística interna (processamento), melhorando os processos internos, revendo fluxos e processos de trabalho, diminuindo as

\footnotetext{
${ }^{66}$ Que já tem ciência antecipada das aquisições, pois participou do Planejamento de Aquisição, logo, não se furtará ao fato de receber o Empenho dentro do prazo de 5 dias.
} 
perdas e aumentando a produtividade, evitando assim que a logística interna tornese uma nova restrição ao sistema (gargalo) devido ao aumento no fluxo da entrega de medicamentos por parte dos Fornecedores.

Figura 23 - Modelo de Otimização do Processo de Aquisição de Medicamentos

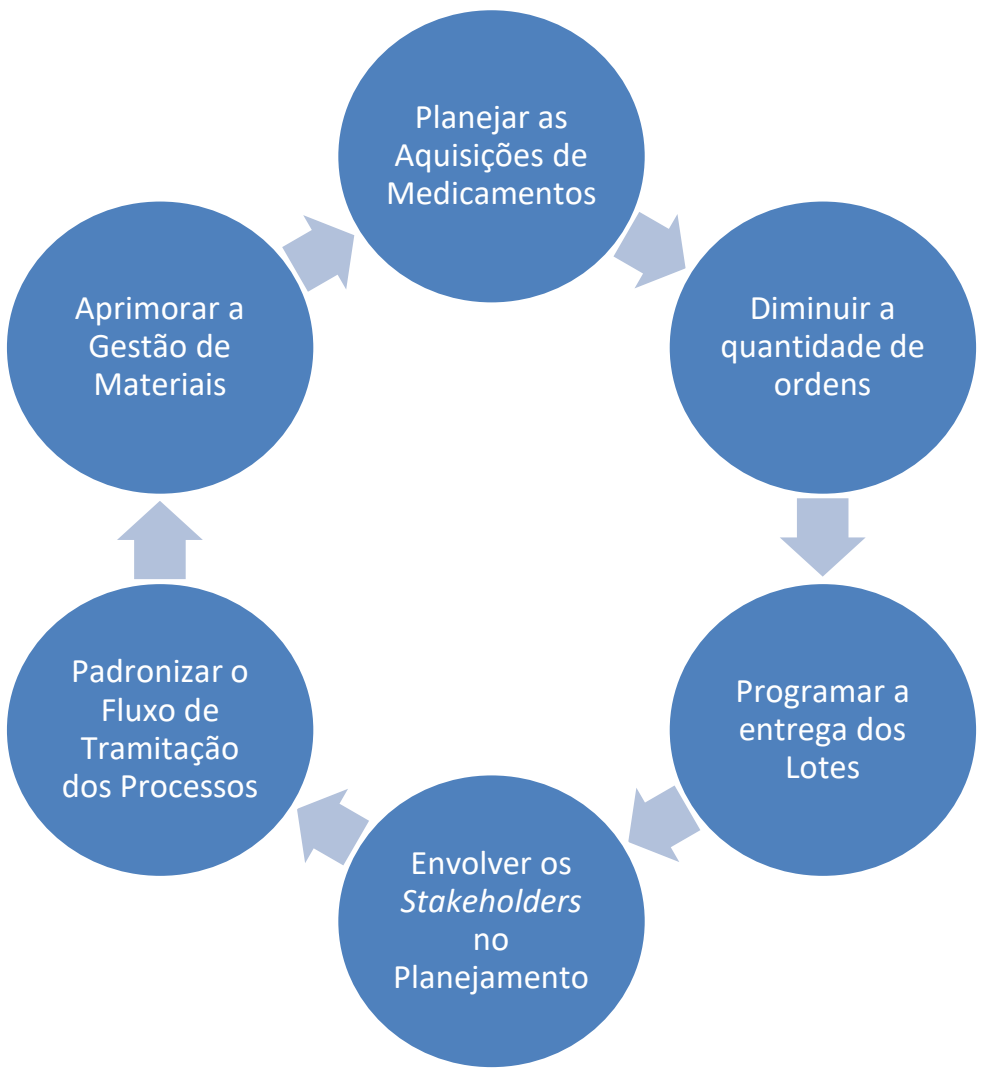

Fonte: Elaborado pelo Autor, 2017. 


\subsection{PAINEL DE INDICADORES PARA A GESTÃO DA CADEIA DE SUPRIMENTOS}

Indicadores auxiliam o processo produtivo de bens ou serviços a mensurar o desempenho de suas atividades, processos ou gestão, demonstrando o comportamento de uma atividade, função ou organização (PONTES, et al., 2008). Bittar (2001) destaca que os indicadores ajudam no processo de tomada de decisão por parte dos gestores. Na mesma direção, Kingeski (2010) afirma que os indicadores são uma importante ferramenta para medir o desempenho da Cadeia de Suprimentos.

A proposta do Painel de Indicadores para a Gestão da Cadeia de Suprimentos de Medicamentos está dividida em dois eixos: (1) Indicadores Financeiros e (2) Indicadores de Produtividade.

\subsubsection{Indicadores Financeiros}

Quadro 44 - Painel de Indicadores Financeiros

\begin{tabular}{|c|c|c|c|c|c|}
\hline $\mathbf{N}$ & Nome & Formula & Escala & Freq. & Fonte \\
\hline$\dot{u}$ & $\begin{array}{l}\text { Percentual da } \\
\text { Dotação } \\
\text { Orçamentária da } \\
\text { Assistência } \\
\text { Farmacêutica } \\
\text { utilizado para } \\
\text { aquisição de } \\
\text { medicamento } \\
\text { (através de Ata) }\end{array}$ & $\begin{array}{l}\sum \text { Empenhos para Aquisição } \\
\text { de Medicamentos } \\
(\text { - } \\
\text { Valor Dotação Orçamentária da } \\
\text { Assistência Farmacêutica }\end{array}$ & $\%$ & $\begin{array}{l}\overline{\frac{\pi}{2}} \\
\frac{\bar{\alpha}}{4}\end{array}$ & $\begin{array}{l}\text { DELOG } \\
\text { Relatório } \\
\text { de } \\
\text { Gestão }\end{array}$ \\
\hline ษิ & $\begin{array}{l}\text { Orçamento } \\
\text { Disponível para } \\
\text { aquisição de } \\
\text { medicamentos }\end{array}$ & $\begin{array}{cc}\text { Valor Dotação } & \sum \text { Empenhos usando } \\
\text { Orçamentária da } & \text { recursos da } \\
\text { Assistência } & \text { Assistência } \\
\text { Farmacêutica } & \text { Farmacêutica }\end{array}$ & $\mathrm{R} \$$ & $\begin{array}{l}\overline{\mathbb{D}} \\
\stackrel{D}{D} \\
\sum^{0}\end{array}$ & $\begin{array}{l}\text { DEPLAN } \\
\text { DFMS }\end{array}$ \\
\hline జี & $\begin{array}{l}\text { Percentual do } \\
\text { Valor dos } \\
\text { Empenhos } \\
\text { entregues no } \\
\text { DELOG }\end{array}$ & $\begin{array}{c}\begin{array}{c}\sum \text { Valor dos Itens Empenhos } \\
\text { Entregues no DELOG }\end{array} \\
\left(\begin{array}{c}\sum \text { Empenhos para Aquisição } \\
\text { de Medicamentos }\end{array}\right.\end{array}$ & $\%$ & 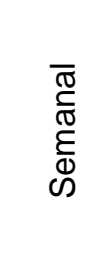 & $\begin{array}{l}\begin{array}{l}\text { Sistema } \\
\text { de } \\
\text { Estoque }\end{array} \\
\text { DELOG }\end{array}$ \\
\hline
\end{tabular}

Fonte: Elaborado pelo autor, 2017. 
O indicador F1 - Percentual da Dotação Orçamentária da Assistência Farmacêutica utilizado para aquisição de medicamento informa ao Gestor qual o percentual da Dotação Orçamentária foi utilizado especificamente para a aquisição de medicamentos ao longo de um ano.

O indicador F2 - Orçamento Disponível para aquisição de medicamentos informa ao Gestor qual o valor da Dotação Orçamentária ainda está disponível para novas aquisições de medicamentos.

O indicar F3 - Percentual do Valor dos Empenhos entregues no DELOG informa ao Gestor o percentual dos valores de medicamentos entregues no DELOG sobre o valor total de medicamentos empenhados. Com esta informação, o Gestor pode mensurar o abastecimento por parte dos Fornecedores.

\subsubsection{Indicadores de Produtividade}

O indicador P1 - Lead Time Tramitação Processo de Aquisição de Medicamentos informa ao Gestor o tempo de duração que o Processo de Aquisição de medicamentos está levando para transitar nos vários Departamentos/Setores da SEMSA.

O indicar P2 - Eficiência na Aquisição de Medicamentos demonstra ao Gestor o grau de eficiência das aquisições de medicamento, onde mensura as ordens de aquisição, através das Notas de Empenhos, e os Empenhos efetivamente entregues no DELOG.

O indicar P3 - Lead Time Aquisição de Medicamento informa ao Gestor o tempo decorrido entre a ordem de aquisição através do Processo de Aquisição de Medicamentos e a entrega dos medicamentos por parte do Fornecedor.

O indicar P4 - Qualidade, mensura a qualidade dos produtos entregues pelos Fornecedores, indicando ao Gestor o percentual de itens fora dos padrões de qualidade (validade, temperatura, embalagem, etc.). 
Quadro 45 - Painel de Indicadores de Produtividade

\begin{tabular}{|c|c|c|c|c|c|c|}
\hline $\mathbf{N}$ & Nome & \multicolumn{2}{|r|}{ Formula } & Escala & Freq. & Fonte \\
\hline 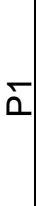 & $\begin{array}{l}\text { Lead Time } \\
\text { Tramitação } \\
\text { Processo de } \\
\text { Aquisição de } \\
\text { Medicamentos }\end{array}$ & $\begin{array}{l}\text { Data Processo } \\
\text { Retorna ao } \\
\text { DELOG }\end{array}$ & $\begin{array}{c}\text { - } \quad \text { Data Memorando de } \\
\text { Aquisição }\end{array}$ & dias & 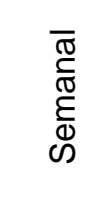 & PROTUS \\
\hline$\stackrel{N}{\alpha}$ & $\begin{array}{l}\text { Eficiência na } \\
\text { Aquisição de } \\
\text { Medicamentos }\end{array}$ & $\begin{array}{r}\text { Qtde. Empe } \\
\text { Entregues pe } \\
\text { ao } \\
\\
\text { Qtde. Emper } \\
\text { de Me }\end{array}$ & \begin{tabular}{l} 
hos Totalmente \\
os Fornecedores \\
DELOG \\
\hdashline hos de Aquisição \\
licamentos
\end{tabular} & $\%$ & 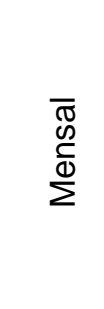 & $\begin{array}{l}\begin{array}{c}\text { Sistema } \\
\text { de }\end{array} \\
\text { Estoque } \\
\text { DELOG }\end{array}$ \\
\hline ח & $\begin{array}{l}\text { Lead Time } \\
\text { Aquisição de } \\
\text { Medicamento }\end{array}$ & $\begin{array}{l}\text { Data da Entrega } \\
\text { de } \\
\text { Medicamento } \\
\text { feita pelo } \\
\text { Fornecedor }\end{array}$ & $\begin{array}{c}\text { - } \quad \text { Data Memorando de } \\
\text { Aquisição }\end{array}$ & dias & 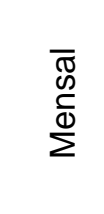 & $\begin{array}{c}\begin{array}{c}\text { Sistema } \\
\text { de } \\
\text { Estoque } \\
\text { DELOG }\end{array}\end{array}$ \\
\hline 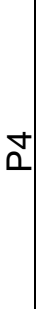 & Qualidade & $\begin{array}{r}\text { Qtde. Itens Med } \\
\text { pelos Forneced } \\
V \epsilon \\
\left(\begin{array}{r}\text { Qtde. Itens } \\
\text { Ad }\end{array}\right.\end{array}$ & \begin{tabular}{l} 
camentos entregues \\
res com Avarias ou \\
ncidos \\
\hdashline$---------------~) \times 100$ \\
Medicamentos \\
juiridos
\end{tabular} & $\%$ & $\begin{array}{l}\bar{D} \\
\mathscr{D} \\
\stackrel{D}{D} \\
\sum\end{array}$ & $\begin{array}{c}\begin{array}{c}\text { Sistema } \\
\text { de }\end{array} \\
\text { Estoque } \\
\text { DELOG }\end{array}$ \\
\hline
\end{tabular}

Fonte: Elaborado pelo autor, 2017. 


\section{CONSIDERAÇÕES FINAIS E RECOMENDAÇÕES}

O objetivo geral desta pesquisa foi propor um modelo de otimização do Processo de Aquisição de medicamentos na Rede Municipal de Saúde de Manaus. O modelo de otimização foi devidamente fundamentado e proposto na pesquisa, sendo: Passo 1 - Planejar as aquisições de medicamentos; Passo 2 - Diminuir a quantidade de ordens de aquisição usando lotes econômicos; Passo 3 - Programar a entrega dos lotes; Passo 4 - Envolver os stakeholders no planejamento da aquisição; Passo 5 - Padronizar o fluxo de tramitação dos processos; Passo 6 Aprimorar a gestão de materiais.

Os objetivos específicos da pesquisa também foram contemplados.

Foi elaborado o (1) Mapeamento do Fluxo Operacional da Gestão da Cadeia de Suprimentos de medicamentos; o (2) Mapeamento o Fluxo de Valor Presente do Processo de aquisição de medicamentos; (3) Identificado as restrições e proposto um Mapa de Valor Futuro para aquisição de medicamentos; (4) foram Apresentadas sugestões de melhorias no Processo de distribuição de medicamentos e (5) Apresentado Painel de Indicadores para Gerenciar os Processos de aquisição de medicamentos.

Diante da análise dos dados da pesquisa, do desenvolvimento da fundamentação teórica e da resolução dos objetivos, foi possível responder a questão norteadora: Quais as principais restrições que afetam o processo de aquisição de medicamentos na rede municipal de saúde de Manaus?

As principais restrições que afetam 0 Processo de Aquisição de Medicamentos encontram-se no abastecimento do medicamento ao Departamento de Logística por parte dos Fornecedores, com (1) um lead time médio de 23,4 dias para retirar e dar ciência na Nota de Empenho quando deveria ser no máximo de 5 dias; (2) lead time médio de 31,8 dia após o Recebimento da Nota de Empenho para fazer a primeira entrega parcial dos medicamentos quando deveria ser feita a entrega total em no máximo 30 dias; (3) lead time médio de 98,1 dias após o recebimento da Nota de Empenho para concluir a entrega total dos medicamentos descritos no Empenho; (4) em média geral apenas 92,21\% do valor total dos Empenhos são efetivamente entregues ao Departamento de Logística.

Conclui-se que a capacidade operacional e logística dos Fornecedores em atender as ordens de aquisição de medicamentos (Notas de Empenho) representam 
as maiores restrições ao processo de aquisição de medicamentos na Rede Municipal de Saúde de Manaus. Por isso a proposta apresentada do Modelo de Otimização do Processo de Aquisição de Medicamentos subordina todo o Processo de Aquisição à restrição, ou seja, aos Fornecedores.

\subsection{RECOMENDAÇÕES}

Diante da amplitude da pesquisa, novos leques podem ser abertos a fim de explorar mais o tema, ficando a sugestão das seguintes pesquisas:

- Levantar o custo para a Secretaria Municipal de Saúde de um Processo de Aquisição de medicamento através de Ata de Registro de Preços;

- Levantar o custo para a Secretaria Municipal de Saúde de um Processo Administrativo para Licitação de medicamentos na modalidade Pregão com a finalidade de gerar uma Ata de Registro de Preços;

- Elaborar um VSM de toda a Cadeia de Suprimentos, desde a aquisição de medicamentos, perpassando a logística interna, até a entrega do medicamento para o usuário do SUS;

- Mensurar os retrabalhos na tramitação dos processos de aquisição e em especial quando da negativa por parte do Fornecedor em receber uma Nota de Empenhos;

- Estudar a relação entre consulta médicas e demanda por medicamentos a fim de encontrar um padrão de comportamento na expedição de medicamentos aos usuários do SUS. 


\section{REFERÊNCIAS BIBLIOGRÁFICAS}

ALVES, Alessandro Pereira. et al. Utilizando os Passos da Teoria das Restrições para a Melhoria Contínua da Produção: um estudo aplicado a uma fábrica de jeans. Revista ADM. MADE. v. 15, n.1, p. 93-114, jan./abr., 2011.

BALLOU, Ronald H. Gerenciamento da cadeia de suprimentos: planejamento, organização e logística empresarial. 4. ed. Porto Alegre: Bookman, 2001.

BALLOU, Ronald $\mathrm{H}$. The evolution and future of logistics and supply chain management. Produção, São Paulo, v. 16, n.3, p. 375-386, set.-dez. 2006.

BITTAR, Olímpio J. Nogueira. Indicadores de qualidade e quantidade em saúde. Revista Administração em Saúde. v. 3, n. 12, jul.-set. 2001.

BOWERSOX, Donald. J; CLOSS, Daviv. J. Logística Empresarial: Processo de Integração da Cadeia de Suprimento. São Paulo: Atlas, 2001.

BOWERSOX, Donald J. Physical Distribution Development, Current Status, and Potential. Journal of Marketing, v. 33, p. 63-70, 1969.

BRASIL. Constituição (1988). Constituição da República Federativa do Brasil. Brasília, DF: Senado Federal: Centro Gráfico, 1988.

BRASIL. Lei n. 8.080, de 19 de setembro de 1990. Dispõe sobre as condições para a promoção, proteção e recuperação da saúde, a organização e o funcionamento dos serviços correspondentes e dá outras providências. Diário Oficial da República Federativa do Brasil, Brasília, 20 set. 1990.

BRASIL. Lei n. 8.666, de 21 de junho de 1993. Regulamenta o Art. 37, inciso XXI, da Constituição Federal, institui normas para licitações e contratos da Administração Pública e dá outras providências. Diário Oficial da República Federativa do Brasil, Brasília, 22 junho. 1993.

BRASIL, Lei n. 10.520, de 17 de julho de 2002. Institui, no âmbito da União, Estados, Distrito Federal e Municípios, nos termos do art. 37, inciso XXI, da Constituição Federal, modalidade de licitação denominada pregão, para aquisição de bens e serviços comuns, é dá outras providências. Diário Oficial da República Federativa do Brasil, Brasília, 17 julho. 2002.

BRASIL, Decreto no 5.450 , de 31 de maio de 2005. Regulamenta o pregão, na forma eletrônica, para aquisição de bens e serviços comuns, e dá outras providências. Diário Oficial da República Federativa do Brasil, Brasília, 31 maio. 2005.

BRASIL. Ministério da Saúde. Secretaria de Ciência, Tecnologia e Insumos Estratégicos. Departamento de Assistência Farmacêutica e Insumos Estratégicos. Assistência Farmacêutica na Atenção Básica: instruções técnicas para sua organização. 2. ed. Brasília: Ministério da Saúde, 2006. 
BRASIL. Tribunal de Contas da União. Licitações e contratos: orientações e jurisprudência do TCU. 4. ed. Brasília: TCU (Secretaria Geral da Presidência): Senado Federal (Secretaria Especial de Editoração e Publicações), 2010.

BRASIL. Decreto no. 7.892, de 23 de janeiro de 2013. Regulamenta o Sistema de Registro de Preços previsto no Art. 15 da Lei no 8.666, de 21 de junho de 1993. Diário Oficial da República Federativa do Brasil, Brasília, 23 jan. 2013.

BRASIL. Serviço Brasileiro de Apoio às Micro e Pequenas Empresas (SEBRAE). Compras Públicas: um bom negócio para a sua empresa. Brasília: SEBRAE, 2014a.

BRASIL. Serviço Brasileiro de Apoio às Micro e Pequenas Empresas (SEBRAE). Pregão Presencial e Eletrônico. Brasília: SEBRAE, 2014b.

BRASIL. Serviço Brasileiro de Apoio às Micro e Pequenas Empresas (SEBRAE). Sistema de Registro de Preços. Brasília: SEBRAE, 2014c.

BRASIL. Ministério do Planejamento. Informações Gerenciais de Contratações e Compras Públicas: janeiro a dezembro de 2014. 2014d. Disponível em: < http://www.comprasgovernamentais.gov.br/arquivos/estatisticas/01-apresentacaosiasg-dados-gerais-_2014.pdf > Acesso em: 01. ago. 2016.

CARDOSO, Grasiele de Oliveira Alves; ALVES, João Murta. Análise crítica da implementação do Lean Office: um estudo de casos múltiplos. GEPROS. Gestão da Produção, Operações e Sistemas, Bauru, ano 8, n. 1, jan-mar/2013, p. 23-35.

CERRA, Aline Lamon. et al. Cadeias de suprimentos de montadoras dos setores automobilístico e de linha branca: uma análise comparativa por meio de estudos de caso. Gestão \& Produção. São Carlos (SP). v. 21, n. 3, p. 635-647, 2014.

CHEN, Injazz J; PAULRAJ, Antony. Towards a Theory of Supply Chain management: the constructs and measurements. Journal of Operations Management. n. 22, p. 119-150, 2004.

COLLATTO, D. C. et al. Práticas de Contabilidade Enxuta: um estudo de sua Aplicação no contexto da Gestão Estratégica de Custos. In: ENCONTRO NACIONAL DE ENGENHARIA DE PRODUÇÃO, 2014. Curitiba. Anais eletrônicos: ENEGEP, $2014 . \quad$ Disponível em:< http://www.abepro.org.br/biblioteca/enegep2014_TN_STO_195_101_25118.pdf>. Acesso em: 30. jan. 2016.

COOPER, Martha C. et al. Supply Chain Management: more than a new name for logistics. The International Journal of Logistics Management. v. 8, n. 1, p. 1-14, 1997.

DEY, Asoke. et al. Building sustainability in logistics operations: a research agenda. Management Research Review, v. 34, n. 11, p. 1237-1259, 2011.

DEZOLT, Ana Lúcia. et al. Compras Públicas Estaduais: boas práticas brasileiras. Impressa Oficial do Estado do Pará. Brasília, 2016. Disponível em: < 
http://consad.org.br/wp-content/uploads/2016/06/Livro-Boas-praticas-de-compraspublicas-v-final-2016.pdf >. Acesso em: 10. ago. 2016.

DOLCI, Pietro Cunha; MAÇADA, Antonio Carlos Gastaud. Information Technology Investments and Supply Chain Governance. Revista de Administração Contemporânea (Anpad). Rio de Janeiro, v. 18, n. 2, p. 217-235, mar./abr, 2014.

ELIAS, Sérgio José Barbosa. et al. Mapeamento do Fluxo de Valor: um estudo de caso em uma industria de gesso. Revista ADMpg Gestão Estratégica. v. 4, n. 1, 2011.

GERHARDT, Tatiana Engel. SILVEIRA, Denise Tolfo. Métodos de pesquisa. Porto Alegre: Editora da UFRGS, 2009. Disponível em: < http://www.ufrgs.br/cursopgdr/downloadsSerie/derad005.pdf> Acesso em: 05.abr.2016

GIL, Antônio Carlos. Como elaborar projetos de pesquisa. 5. ed. São Paulo: Atlas, 2010.

GONÇALVES, José Ernesto Lima. Processo, que Processo? Revista de Administração de Empresas (RAE). São Paulo, v. 40, n. 4, p.8-19, out./dez., 2000.

GONZALEZ, Ernesto Santibanez; SOUZA, Marcone Jamilson Freitas. A Conceptual Analysis of Supply Chain Management. In: XVI INTERNATIONAL CONFERENCE ON INDUSTRIAL ENGINEERING AND OPERATIONS MANAGEMENT. 2010. São Carlos. Anais eletrônicos: ABEPRO, 2010.

GUERREIRO, Reinaldo. et al. Logística Integrada, Gestão da Cadeia de Suprimentos e Mensuração de Custos e Resultados Logísticos: um estudo com empresas brasileiras. Advances in Scientific and Applied Accounting. São Paulo, v. 4, n. 1, p. 73-100. 2011.

HARLAND, Christine M. et al. Developing the concepto of supply strategy. International Journal of Operations \& Production Management. v. 19, n. 7, p. 650-673, 1999.

JABBOUR, Ana Beatriz Lopes de Sousa. et al. Práticas de Gestão da Cadeia de Suprimentos e seus Eventuais Relacionamentos com as Prioridades Competitivas da Produção: evidências empíricas do setor eletroeletrônico à luz de modelagem de equações estruturais. Produção. São Paulo, v. 23, n. 2, p. 241-256, abr./jun. 2013.

KINGESKI, Luciano. Medição de Desempenho em Cadeia de Suprimentos: um estudo descritivo em uma empresa do setor automobilístico - GNK do Brasil. In: ENCONTRO NACIONAL DE ENGENHARIA DE PRODUÇÃO, 2010. São Carlos (SP). Anais eletrônicos: ENEGEP, 2010. Disponível em:< http://www.abepro.org.br/biblioteca/enegep2010_tn_sto_113_739_15225.pdf >. Acesso em: 01. mar. 2017. 
LAMBERT, Douglas M. et al. Supply Chain Management: implementation issues and research opportunities. International Journal of Logistics Management. v. 9, n. 2, 1998.

LAMBERT, Douglas M. The Eight Essential Supply Chain Management Processes. Supply Chain Management Review, v. 8, n. 6, p.18-25, set. 2004.

LAMBERT, Douglas M. An executive summay of supply chain management: processes, partnerships, performance. Flórida (USA): Supply Chain Management Institute, 2008.

LAMBERT, Douglas M. Customer Relationship Management as a Business Process. Journal of Business \& Industrial marketing. v. 25, n. 1, p. 4-17, 2010.

LEONE, George Sebastião Guerra. Custos: planejamento, implantação e controle. 3. ed. São Paulo: Atlas, 2000.

LIBRELATO, Tatiane Pereira. et al. A Process Improvement Approach Based on the Value Stream Mapping and the Theory of Constraints Thinking Process. Business Process Management Journal. v. 20, n. 6 p. 922-949, 2014.

LIMA, Cristiano Barbosa de; SOUZA JÚNIOR, Armando de Souza. Estudo de Caso: aplicação do lean office no setor de recebimento do Departamento de Logística da SEMSA. Monthly Multidisciplinary Research Journal. v. 6, n. 4, jan., 2017.

LUMMUS, Rhonda R; VOKURKA, Robert J. Defining Supply Chain Management: a historical perspective and practical guidelines. Industrial Management \& Data Systems. v. 99, n. 1 p. 11-17, 1999.

MACHLINE, Claude. Cinco décadas de logística empresarial e administração da cadeia de suprimentos no Brasil. Revista de Administração de Empresas, São Paulo, v. 51, n. 3, p. 227-231, maio-jun. 2011.

MAIA, Rafaella Dias de Almeida. et al. O Value Stream Mapping e sua Relação com os Princípios da Abordagem Enxuta: proposição de uma sistemática expandida para a gestão do lead time. In: XXX ENEGEP, São Carlos/SP, 12-15, out, 2010. Disponível em:

http://www.abepro.org.br/biblioteca/enegep2010_TN_STO_113_745_16535.pdf >. Acesso em: 25. ago. 2016.

MANAUS. Decreto n. 2.681, de 26 de dezembro de 2013. Dispõe sobre o Regimento Interno da Secretaria Municipal de Saúde e dá outras providências. Diário Oficial do Município de Manaus, n. 3319, Manaus, 26. dez. 2013.

MANAUS. Lei n. 1.975, de 29 de abril de 2015. Dispõe sobre a reorganização administrativa do Poder Executivo Municipal, e dá outras providências. Diário Oficial do Município de Manaus, n. 3637, Manaus, 29. abr. 2015. 
MARTINS, Carlos. Fernando. et al. Implantação do Lean Office: uma aplicação de caso no Senai Santa Catarina. In: VIII CONGRESSO NACIONAL DE EXCELÊNCIA E GESTÃO, 8 e 9 jun, 2012. Anais eletrônicos. Disponível em: < http://www.excelenciaemgestao.org/portals/2/documents/cneg8/anais/t12_0504_259 6.pdf>. Acesso em: 15 jan. 2015.

MENTZER, John T. et al. Defining Supply Chain Management. Journal of Business Logistics. v. 22, n. 2, 2001.

NOGUEIRA NETO, Mário de Souza; SACOMANO, José Benedito. O Fluxo de Informações em Cadeia de Suprimentos: prospecção em dois grupos de empresas. Revista de Administração da UNIMEP. São Paulo, v. 8, n. 1, jan./abr. 2010.

OTHON, Marione de Lima Pessoa; ARAÚJO, Richard Medeiros de. Compras públicas no âmbito do sistema de pregão: um estudo com funcionários públicos. Diálogo. Canoas (RS). n. 30, p. 9-28, dez, 2015.

PACHECO, Diego Augusto de Jesus. Teoria das Restrições, Lean Manufacturinge Seis Sigma: limites e possibilidades de integração. Production. v. 24, n. 4, p. 940 956, out./dec. 2014.

PADOVEZE, Clóvis Luís. Curso básico gerencial de custos. 2. ed. São Paulo: Cengage Learning, 2011.

PERGHER, Isaac. et al. Discussão Teórica sobre o conceito de perdas do Sistema Toyota de Produção: inserindo a lógica do ganho da Teoria das Restrições. Gestão \& Produção. São Carlos (SP). v. 18, n. 4, p. 673-686, 2011.

PINTO, Alfredo Augusto Gonçalves. et. al. Gestão de custos. 2. ed. Rio de Janeiro: FGV, 2009.

PONTES, Andre Teixeira. et al. A Utilização de Indicadores de Desempenho no Setor de Suprimentos Hospitalares: uma revisão da literatura. In: ENCONTRO NACIONAL DE ENGENHARIA DE PRODUÇÃO, 2008. Rio de Janeiro. Anais eletrônicos: $\quad$ ENEGEP, $2008 . \quad$ Disponível em:< http://www.ceatenf.ufc.br/ceatenf_arquivos/Artigos/16.pdf >. Acesso em: 01. mar. 2017.

PRATES, Caroline Chagas; BANDEIRA, Denise Lindstrom. Aumento de eficiência por meio do mapeamento do fluxo de produção e aplicação do Índice de Rendimento Operacional Global no processo produtivo de uma empresa de componentes eletrônicos. Gestão e Produção. v. 18, n. 4, p. 705-718, 2011.

PRODANOV, Cleber Cristiano. FREITAS, Ernani Cesar de. Metodologia do trabalho Científico: métodos e técnicas da pesquisa e do trabalho acadêmico. 2. ed. Novo Hamburgo: Feevale, 2013. Disponível em: < http://www.faatensino.com.br/wpcontent/uploads/2014/11/2.1-E-book-Metodologia-do-Trabalho-Cientifico-2.pdf > Acesso em: 04. Abr.2016. 
ROTHER, Mike.; SHOOK, John. Aprendendo a enxergar: mapeando o fluxo de valor para agregar valor e eliminar o desperdício. São Paulo: Lean Institute Brasil, 2003.

SANTOS, Izequias Estevam dos. Manual de Métodos e Técnicas de Pesquisa Científica. 5. ed. Niterói: Impetus, 2005.

SANTOS, Reinaldo Fagundes dos.; ALVES, João Murta. Proposta de um modelo de gestão integrada da cadeia de suprimentos: aplicação no segmento de eletrodomésticos. Production, São Paulo, v. 25, n. 1, p. 125-142, jan./mar. 2015.

SERAPHIM, Everton Cesar. et al. Lean Office em organizações militares de saúde: estudo de caso do Posto Médico da Guarnição Militar de Campinas. Gestão e Produção. v. 17, n. 2, p. 389-405, 2010.

SETH, Dinesh. et. al. Application of Value Stream Mapping (VSM) for Minimization of Wastes in the Processing Side of Supply Chain of Cottonseed Oil Industry in Indian Context. Journal of Manufacturing Technology Management. v. 19, n. 4, p. 529550, 2008.

SEVERINO, Antônio Joaquim. Metodologia do Trabalho Científico. 23. ed. São Paulo: Cortez, 2007.

SIMATUPANG, Togar M. et al. Applying the Theory of Constraints to Supply Chain Collaboration. An International Journal. v. 9, n. 1, p. 57-70, 2004.

SIMON, Alexandre Tadeu. et al. Evaluating Supply Chain Management: a methodology based on a theoretical model. Revista de Administração Contemporânea (Anpad), Rio de Janeiro, v. 19, n. 1, p. 26-44, jan./fev. 2015.

SIMON, Alexandre Tadeu; PIRES, Sílvio Roberto Ignácio. Metodologia para Análise da Gestão da Cadeia de Suprimentos: estrutura, processos de negócios e componentes de gestão. Revista de Ciência \& Tecnologia. v. 11, n. 22, p. 57-66, jul./dez. 2003.

SOUZA, Ana Luíza Pimenta de. et al. A Rede Brasileira de Produção Pública de Medicamentos na perspectiva da gestão de cadeias de suprimentos: o papel das TIC. Revista Administração Pública. Rio de Janeiro, p. 615-641, maio/jun. 2015.

SOUZA, Marco Antônio de. et al. Comercio Tradicional Versus Comércio Eletrônico: um estudo de caso sob o olhar da gestão dos custos logísticos. Sociedade, Contabilidade e Gestão. Rio de Janeiro, v. 9, n. 2, mai/ago. 2014.

TABANLI, R. Murat; ERTAY, Tijen. Value Stream Mapping and Benefit - Cost Analysis Application for Value Visibility of a Pilot Project on RFID Investment Integrated to a Manual Production Control System - a case study. The International Journal of Advanced Manufacturing Technology. v. 66, p. 987-1002, 2013. 
TALAMINI, Edson. et al. Gestão da cadeia de suprimentos e a segurança do alimentos: uma pesquisa exploratória na cadeia exportadora da carne suína. Gestão \& Produção, São Carlos (SP), v. 12, n. 1, p. 107-120, jan-abr. 2005.

TAPPING, D.; SHUKER, T. Lean Office: gerenciamento do fluxo de valor para áreas administrativas: 8 passos para planejar, mapear e sustentar melhorias Lean nas áreas administrativas. São Paulo: Ed. Leopardo, 2010.

TRIDAPALLI, Juarez Paulo; FERRER, Florencia. Processo e-compras: Governo do Estado do Amazonas. In: XI CONGRESO INTERNACIONAL DEL CLAD SOBRE LA REFORMA DEL ESTADO Y DELA ADMINISTRACIÓN PÚBLICA, Ciudad de Guatemala, 7-10, nov, 2006. Disponível em: < http://siare.clad.org/fulltext/0055422.pdf>. Acesso em: 25. ago. 2016.

TRIDAPALLI, Juarez Paulo. Comércio eletrônico: uma perspectiva no setor público para melhoria da logística. 2008. Tese (doutorado em engenharia de transportes). Universidade Federal do Rio de Janeiro, Rio de Janeiro, 2008.

TRIDAPALLI, Juarez Paulo. et al. Gestão da Cadeia de Suprimento do Setor Público: uma alternativa para controle de gastos correntes no Brasil. Revista de Administração Pública. Rio de Janeiro, v. 45, n. 2, p. 401-433, mar./abr. 2011.

TRIDAPALLI, Juarez Paulo; BORINELLI, Benilson. Compras Públicas: divergências de preços praticados entre os níveis de Governo e o mercado privado do Estado do Amazonas. In: VIII CONGRESSO DE GESTÃO PÚBLICA - CONSAD, Brasília/DF, 26-28, maio, 2015 . Disponível em: http://banco.consad.org.br/handle/123456789/1221 >. Acesso em: 25. ago. 2016.

TYAGI, Satish. et al. Value Stream Mapping to Reduce the Lead-time of a Product Development Process. International Journal of Production Economics. v. 160, p. 202-212, 2015.

TURRIONI, João Batista. MELLO, Carlos Henrique Pereira. Metodologia de Pesquisa em Engenharia de Produção: estratégias, métodos e técnicas para condução de pesquisas quantitativas e qualitativas. Universidade Federal de Itajubá (UNIFEl), $2012 . \quad$ Disponível em http://www.carlosmello.unifei.edu.br/Disciplinas/Mestrado/PCM-10/Apostila-

Mestrado/Apostila_Metodologia_Completa_2012.pdf>. Acesso em: 30.maio.2016.

TURATI, Ricardo de Carvalho. MUSETTI, Marcel Andreotti. Aplicação dos Conceitos de Lean Office no Setor Administrativo Público. In: XXVI ENEGEP, Fortaleza/CE, 911, out, 2006. Disponível em: < http://www.abepro.org.br/biblioteca/enegep2006_tr450313_7184.pdf >. Acesso em: 25. ago. 2016.

VANELSLANDER, Thierry; MUSSO, Enrico. Transport, Logistics and the Supply Chain: how changes reshape the research agenda. International Journal of Transport Economics. v. 42, n. 1, mar. 2015. 
VOTTO, Rodrigo Goulart; FERNANDES, Flavio Cesar Faria. Produção enxuta e teoria das restrições: proposta de um método para implantação conjunta na Indústria de Bens de Capital sob Encomenda. Gestão \& Produção, São Carlos (SP), v. 21, n. 1, p. 45-63, 2014.

WANKE, Peter Fernandes; CORRÊA, Henrique Luiz. The relationship between the logistics complexity of manufacturing companies and their supply chain management. Production, São Paulo, v. 24, n. 2, p. 233-254, Abr./Jun. 2014.

WATSON, Kevin J. et al. The evolution of a management philosophy: the theory of constraints. Journal of Operations Management. v. 25, p. 387-402, 2007.

WOMACK, J. P.; JONES, D. T. A mentalidade enxuta nas empresas: elimine o desperdício e crie riqueza. Rio de janeiro: Campus, 2003.

YIN, Robert K. Estudo de Caso: planejamento e métodos. 4. ed. Porto Alegre: Bookman, 2010.

ZANELLA, Liane Carly Hermes. Metodologia de estudo e de pesquisa em administração. Florianópolis: UFSC; Brasília: CAPES, 2009. Disponível em: < http://www.aedmoodle.ufpa.br/pluginfile.php?file=\%2F21055\%2Fmod_resource\%2Fc ontent\%2F0\%2FMetodologia.pdf>. Acesso em 30. mar. 2016. 
ANEXO 1 - CALENDÁRIO DE ABASTECIMENTO DE MEDICAMENTOS PRIMEIRO SEMESTRE 2015

SECRETARIA MUNICIPAL DE SAÚDE - SEMSA

CALENDÁRIO DE ABASTECIMENTO - ANO 2015 (JANEIRO À JUNHO)

\begin{tabular}{|c|c|c|c|c|c|c|c|c|c|c|}
\hline $\begin{array}{l}N^{\circ} \\
\text { Ord }\end{array}$ & ZONA & UNIDADE DE SAÚDE & & DEZ & JAN & FEV & MAR & ABR & MAI & JUN \\
\hline 1 & & \begin{tabular}{|l|} 
Laboratório Distrital \\
ano
\end{tabular} & \multirow{10}{*}{ 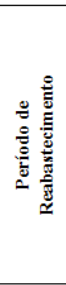 } & \multirow{10}{*}{ 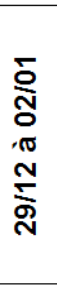 } & \multirow{10}{*}{ 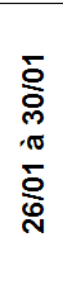 } & \multirow{10}{*}{$\begin{array}{l}\text { N } \\
\stackrel{N}{N} \\
\text { N } \\
\text { N } \\
\text { N }\end{array}$} & \multirow{10}{*}{ 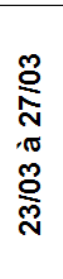 } & \multirow{10}{*}{ 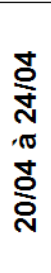 } & \multirow{10}{*}{ 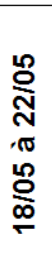 } & \multirow{9}{*}{ 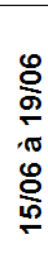 } \\
\hline$\frac{2}{3}$ & & \begin{tabular}{|l} 
UBS Dr. Platão de Araújo \\
UBS Dr. Silas de Oliveira
\end{tabular} & & & & & & & & \\
\hline 4 & & UBS Enf Josephina de Mello & & & & & & & & \\
\hline 5 & & Policlinica Dr. Comte Telles & & & & & & & & \\
\hline 6 & & UBS Dr. José Avelino Pereira & & & & & & & & \\
\hline 7 & & USBS Enf Ivone Lima dos Santos & & & & & & & & \\
\hline 8 & & UBS Cacilda de Freitas & & & & & & & & \\
\hline 9 & & \begin{tabular}{|l} 
UBS Gilson Moreira \\
\end{tabular} & & & & & & & & \\
\hline 10 & 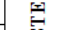 & UBS Guilherme Alexandre & & & & & & & & \\
\hline 11 & $\sqrt{x}$ & UBS João Nogueira da Mata & & & & & & & & \\
\hline 12 & & UBS José Amazonas Palhano & & & & & & & & \\
\hline 13 & & UBS Lago do Aleixo & & & & & & & & \\
\hline 14 & & UBS Leonor Brilhante & $\stackrel{ْ}{=}$ & & & & & & & \\
\hline 15 & & UBS Luiza do Carmo Ribeiro & 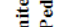 & $N$ & & & $\frac{2}{\pi}$ & & & \\
\hline 16 & & \begin{tabular}{|l} 
UBS Geraldo Magela \\
\end{tabular} & 里 & రृ & $\cong$ & $\stackrel{\oplus}{\longleftarrow}$ & $\boldsymbol{\varepsilon}$ & तั & $\varepsilon$ & 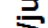 \\
\hline 17 & & UBS Mauazinho & $\underline{\underline{z}}$ & & & $\overline{\mathrm{N}}$ & $\infty$ & n) & $\bar{m}$ & 0 \\
\hline 18 & & UBS Nova Esperança & 岸 & & & & & & & \\
\hline 19 & & UBS Alfredo Campos & 亩 & & & & & & & \\
\hline 20 & & UBS Gebes Medeiros & & & & & & & & \\
\hline 21 & & 37 UBSF+Escolas (Odonto) & & & & & & & & \\
\hline 1 & & Laboratório Distrital & & & & & & & & \\
\hline 2 & & UBS Arthur Virgilio Fillho & & $\overline{0}$ & ָ̃ & ?్ֶ & ষ & ষ্ণ & ? & 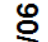 \\
\hline 3 & & UBS Balbina Mestrinho & 茲 & 8 & $\mathscr{8}$ & $\mathscr{8}$ & $\mathcal{O}$ & శ్లి & ก & $\stackrel{\text { N }}{1}$ \\
\hline 4 & & UBS Frei Valério Di Carlo & 党 & 20 & $\stackrel{\infty}{n}$ & $\stackrel{10}{m}$ & m & $\stackrel{+\infty}{+\infty}$ & 20 & 0 \\
\hline 5 & 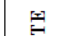 & UBS Sákvio Belota & & फ & สู้ & สู & के & 空 & เึ & ลี \\
\hline 6 & 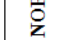 & Policlinica Enf Ana Barreto & & & & & & & & \\
\hline 7 & & Policlinica José Antonio da Silva & $\stackrel{8}{8}$ & & & & & & & \\
\hline 8 & & UBS Armando Mendes & 产 & $\underset{\mathbb{N}}{\mathbb{N}}$ & $\frac{5}{\pi}$ & $\vec{d}$ & $\stackrel{\overline{\widetilde{T}}}{\varepsilon}$ & 高 & $\stackrel{\bar{\pi}}{\varepsilon}$ & 气 \\
\hline 9 & & UBS Augias Gadelha & 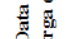 & হ్ & $\stackrel{\infty}{N}$ & ฌั & 岕 & กิ & D্ & $\approx$ \\
\hline 10 & & 43 UBSF+CEO+Escolas (Odonto) & 룜 & & & & & & & \\
\hline 1 & & \begin{tabular}{|l|} 
Laboratório Distrial \\
\end{tabular} & & & & & & & & \\
\hline 2 & & Maternidade Moura Tapajos & & & & & & & & \\
\hline 3 & & Policlinica José Rdo. Franco de Sá & & & & & J & & & \\
\hline $\begin{array}{l}4 \\
5\end{array}$ & & \begin{tabular}{|l|} 
UBS Deodato de M. Leão \\
UBS Dialma Batista
\end{tabular} & ๑气 & 응 & m & m & 亏े & $\stackrel{\infty}{\infty}$ & เू & ले \\
\hline 6 & & \begin{tabular}{|l} 
UDS Djamam Milton Corrêa \\
UBS Dom
\end{tabular} & 至 & $\bar{\pi}$ & $\bar{\sigma}$ & $\bar{\sigma}$ & $\bar{\pi}$ &.$\pi$ & 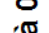 & $\pi$ \\
\hline 7 & & UBS Leonor de Freitas & 党 & 10 & $\sim$ & $m$ & $\theta$ & 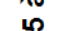 & 0 & 0 \\
\hline 8 & & UBS Lindalva Damasceno & $2 \frac{\mathrm{g}}{\mathrm{y}}$ & 응 & O & ó & ○ & 은 & 으 & ○ั \\
\hline 9 & & \begin{tabular}{|l} 
UBS Luiz Montenegro \\
\end{tabular} & & $\overline{\mathrm{N}}$ & के & के & $\Phi$ & 吾 & $=$ & D్ \\
\hline 10 & $\vec{s}$ & UBS Mansour Bulbol & & & & & & & & \\
\hline 11 & 중 & UBS Maria Ida Mentoni & & & & & & & & \\
\hline 12 & & UBS Santo Antônio & & & & & & & & \\
\hline 13 & & \begin{tabular}{|l} 
UBS São Vicente de Paulo \\
\end{tabular} & & & & & & & & \\
\hline 14 & & UBS Vila da Prata & $\stackrel{ْ}{=}$ & & & & & & & \\
\hline 15 & & UBS Ajuricaba & 产 & $=$ & $\longrightarrow$ & 亭 & ڤั & 흐 & $\bar{\pi}$ & 气 \\
\hline 16 & & \begin{tabular}{|l} 
UBS Bairro da $\mathrm{Paz}$ \\
\end{tabular} & 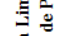 & $\stackrel{\sigma}{=}$ & $\stackrel{ \pm}{ \pm}$ & $\underline{\xi}$ & $\frac{\sqrt{0}}{2}$ & $\frac{\pi}{\sqrt{2}}$ & $\xi$ & $\stackrel{2}{2}$ \\
\hline 17 & & \begin{tabular}{|l} 
UBS Rayol dos Santos \\
\end{tabular} & J & 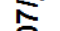 & 寸 & $\overline{\mathrm{z}}$ & $\overline{5}$ & क्ष & $\overline{\mathbf{N}}$ & 于 \\
\hline 18 & & UBS Redenção & 垔 & & & & & & & \\
\hline 19 & & 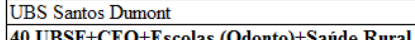 & 亩 & & & & & & & \\
\hline 1 & & Laboratório Distrital & & & & & & & & \\
\hline 2 & & Policlinica Antonio Reis & & & & & & & & \\
\hline 3 & & SAMU & 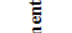 & & & & & & & \\
\hline 4 & & 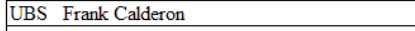 & 恶 & 을 & 응 & 옹 & 은 & 응 & 응 & 응 \\
\hline 5 & & UBS Lourenço Borghi & 索 & $\dddot{M}$ & 오 & 오 & $\approx$ & $\stackrel{n}{\sim}$ & $\stackrel{\simeq}{\simeq}$ & 음 \\
\hline 6 & & UBS Lúcio Flávio V. Dias & 要 & $\frac{\pi}{4}$ & $\int^{\infty}$ & $\frac{\pi}{n}$ & $\bar{\pi}$ &. $\bar{\pi}$ & $\bar{\sigma}$ & $\bar{\pi}$ \\
\hline 7 & & UBS Olavo das Neves (Matinha) & $\check{~}$ & 10 & $\mathbf{N}$ & $m$ & $\dot{z}$ & u & 0 & 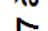 \\
\hline 8 & & UBS São Francisco & \% & 5 & O & O & ○ & 웅 & 무 & 5 \\
\hline 9 & & UBS Theodomiro Garrido & 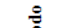 & ら & छ & $\underline{\underline{\theta}}$ & $\underline{m}$ & $\Xi$ & $\infty$ & 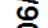 \\
\hline 10 & & UBS Almir Pedreira & 选 & & & & & & & \\
\hline 11 & 5 & UBS Bianca de A. Carvalho & & & & & & & & \\
\hline 12 & 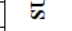 & Policlinica Castelo Branco & & & & & & & & \\
\hline 13 & & UBS Dr. Luiz Montenegro & & & & & & & & \\
\hline 14 & & UBS Japiim & $=$ & & & & & & & \\
\hline 15 & & UBS José Rayol dos Santos & $\therefore$ & & & & & & & \\
\hline 16 & & UBS Megumo Kado & get & & & & & & $\subseteq$ & \\
\hline 17 & & UBS Morro da Liberdade & $\bar{E}$ & $\stackrel{0}{\longrightarrow}$ & $\Phi$ & $\varepsilon$ & $\frac{10}{10}$ & E & $\stackrel{2}{3}$ & 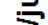 \\
\hline 18 & & \begin{tabular}{|l} 
UBS Petropólis \\
\end{tabular} & 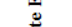 & 于 & क & $\equiv$ & $\infty$ & $\bar{\emptyset}$ & ง & 5 \\
\hline 19 & & UBS Santa Luzia & 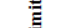 & $\leftarrow$ & 0 & $\leftarrow$ & 0 & & 0 & \\
\hline 20 & & UBS Theomário P. da Costa & 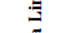 & & & & & & & \\
\hline 21 & & UBS Vicente Pallotti & $\underline{\underline{g}}$ & & & & & & & \\
\hline 22 & & 53 UBSF+CEO+Escolas (Odonto) & 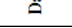 & & & & & & & \\
\hline
\end{tabular}




\section{ANEXO 2 - CALENDÁRIO DE ABASTECIMENTO DE MEDICAMENTOS - SEGUNDO SEMESTRE 2016}

SECRETARIA MUNICIPAL DE SAÚDE - SEMSA

CALENDÁRIO DE ABASTECIMENTO - ANO 2016 (JULHO À DEZEMBRO)

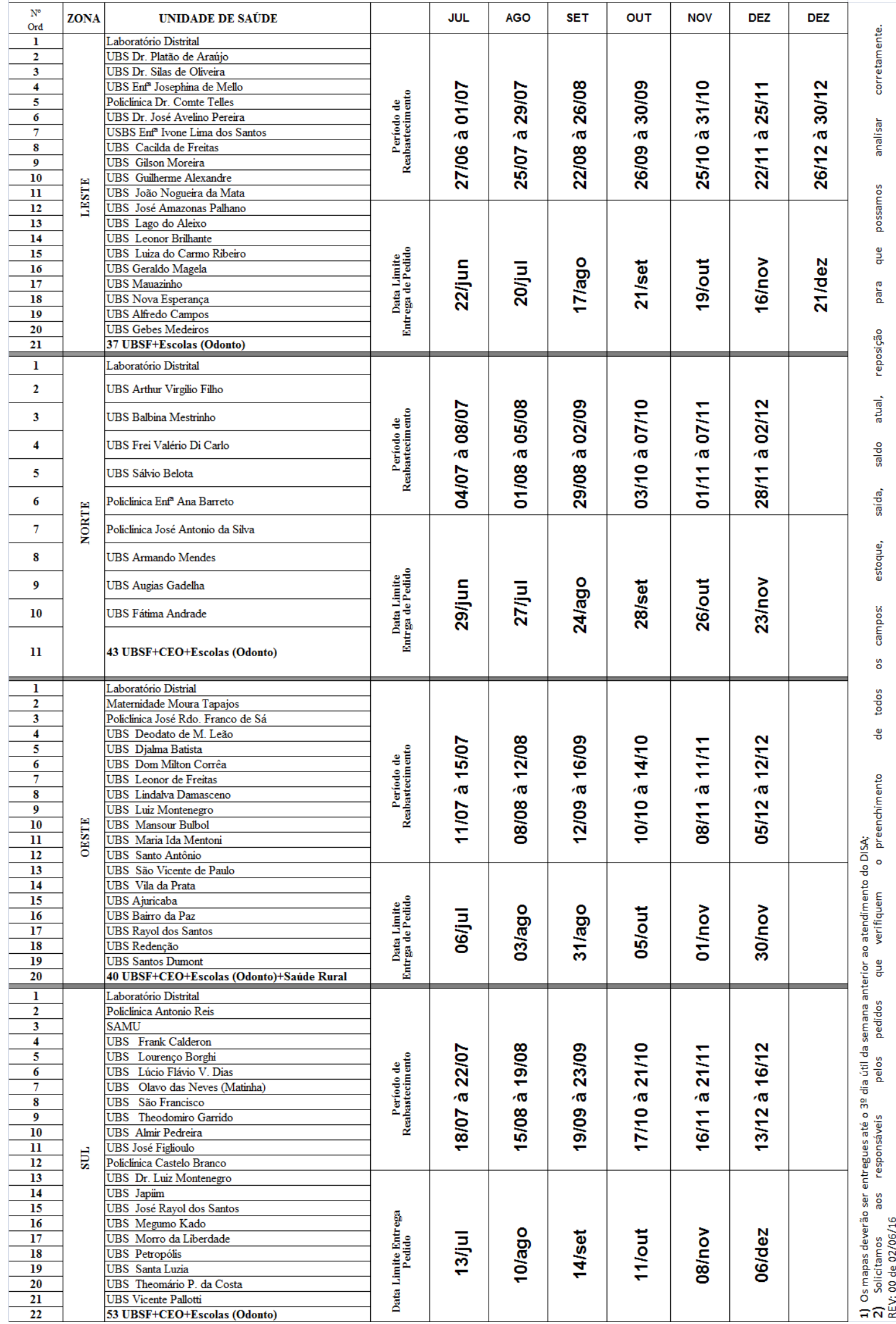


ANEXO 3 - MAPA DE ABASTECIMENTO DE MEDICAMENTOS

$=$

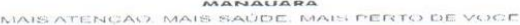

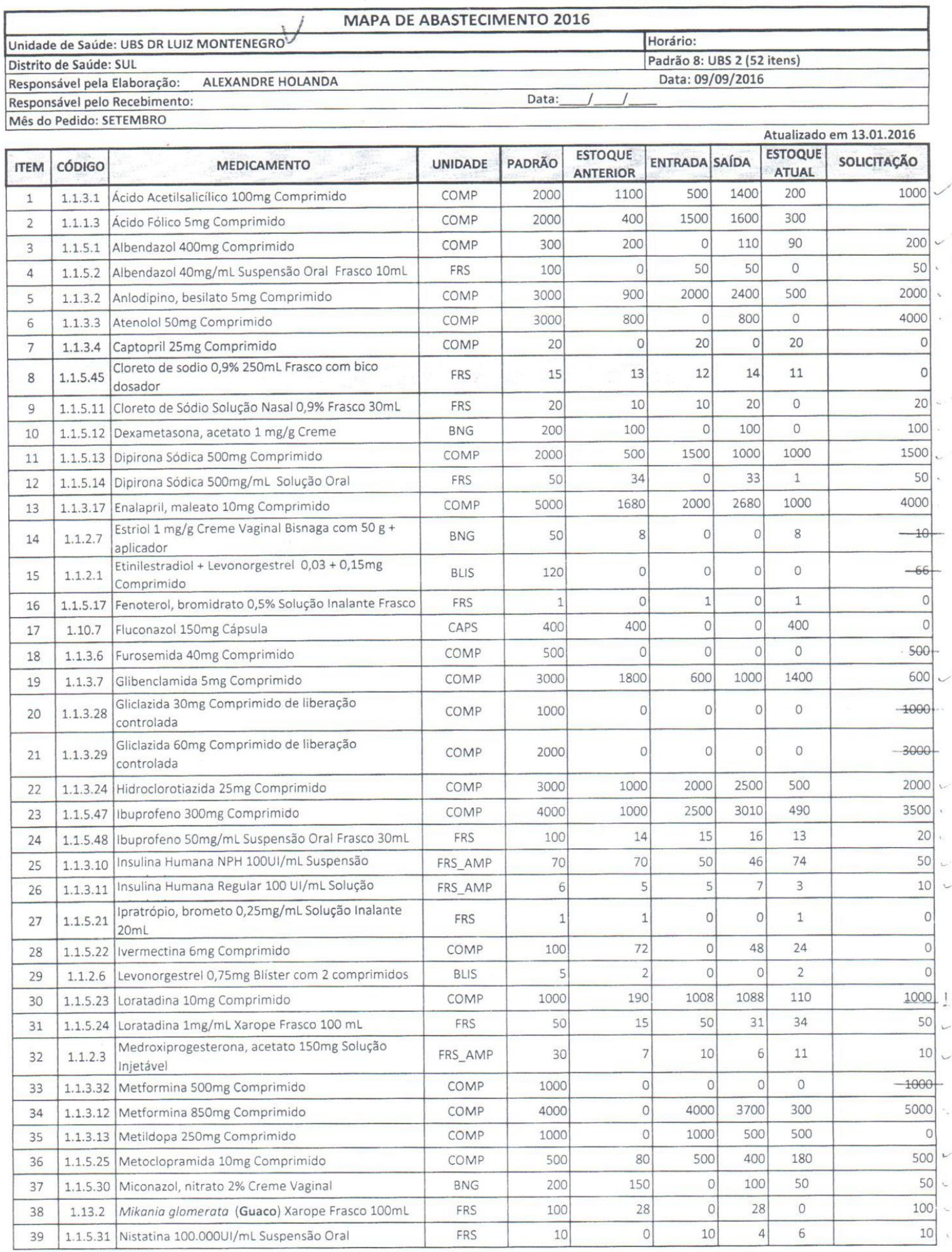

